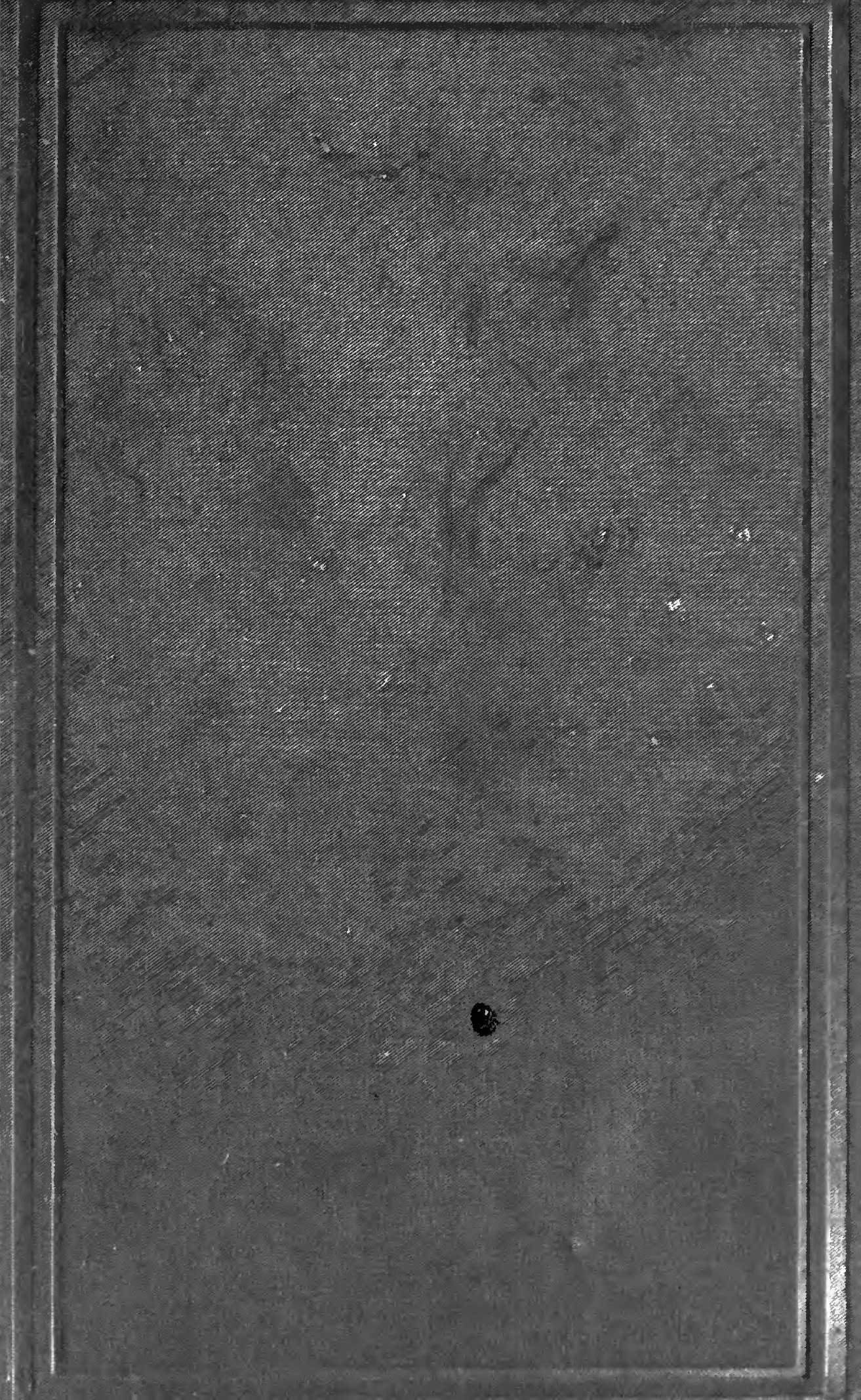



$-9 /-$

$$
t i
$$







\section{THE IIAYA INDIANS OF SOUTHERI YUCATAN AND NORTHERI BRITISII HONDURAS}

BY

THOMAS W. F. GANN

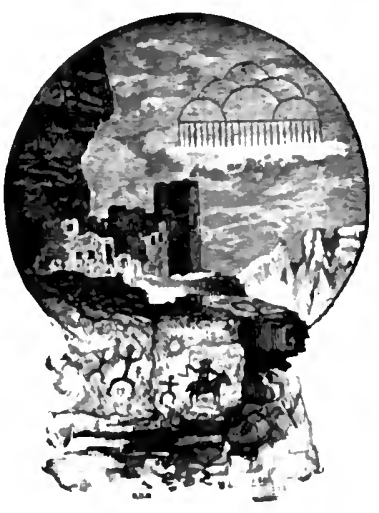


10 my densfriens?

Ih. W. F.gam 


\section{LETTER OF TRANSMITTAL}

Washington, D. C., November 4, 1916.

SIR: I have the honor to transmit herewith tho manuscript of a memoir entitled "Tho Maya Indians of Southern Yucatan and Northem British Honduras," by Thomas IF. F. Gann, and to recommend its publication as a bulletin of the Bureau of American Ethnology.

Very respectfully,

Hon. Cinarles D. Walcot",

F. IV. Hodge, Ethnologist-in-Charge.

Secretary, Smithsonian Institution. 



\section{CONTENTS}

Part 1. ('ustons, ('eremonies, and Mode of Life

Introduction

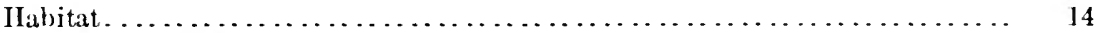

Personal characteristics. . . . . . . . . . . . . . . . . . . . . . . . . . 15

Dress. . . . . . . . . . . . . . . . . . . . . . . . . . . . . . . . 18

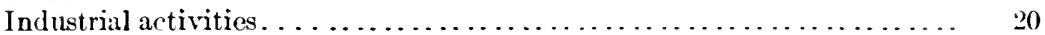

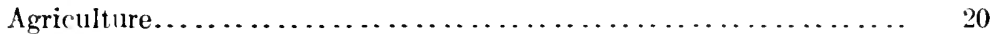

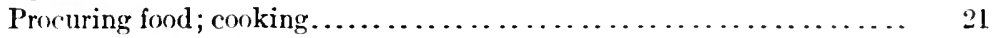

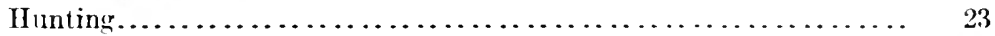

Fishing. . . . . . . . .

('onstruction of houses and furniture ..................... 26

Pottery making. . . . . . . . . . . . . . . . . . . . . . . . . . . 28

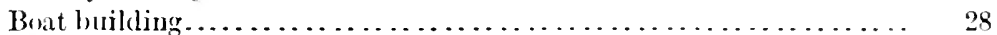

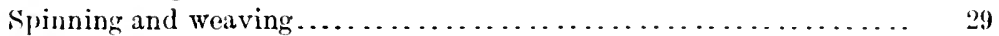

Minor industries. . . . . . . . . . . . . . . . . . . . . . . . . . . 30

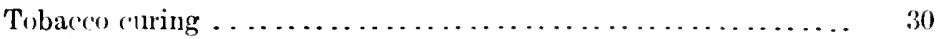

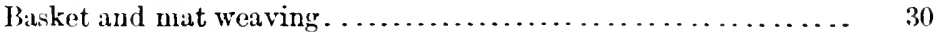

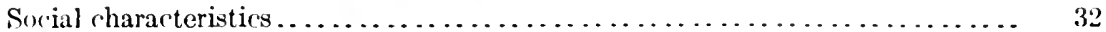

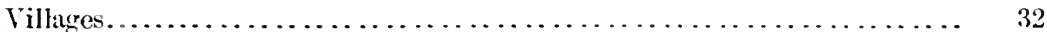

Marriagre and children ............................... 32

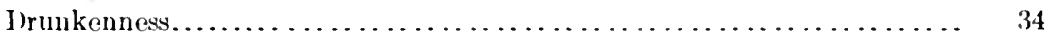

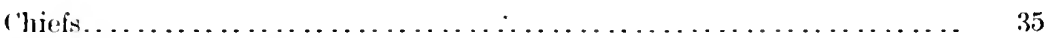

l)iseases and medicines. . . . . . . . . . . . . . . . . . . . . . . 36

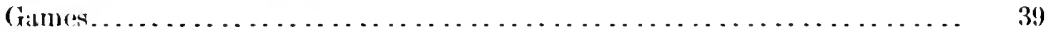

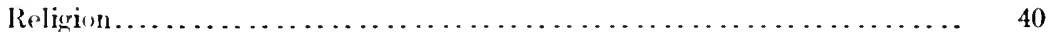

\section{Part 2. Mound Excavation in the Eastern Maya Area}

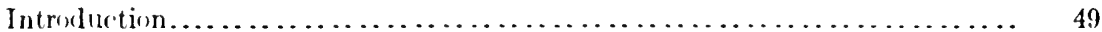

Claswification of the mounds. . . . . .

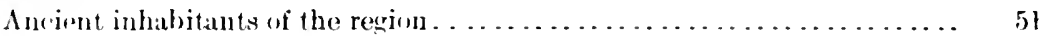

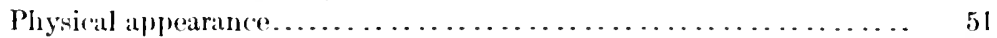

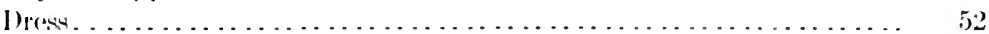

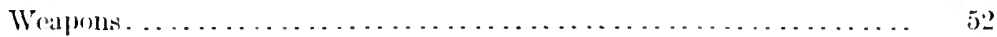

Ilouses. . . . . . . . . .

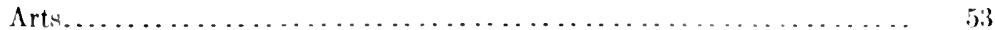

Musicul instruments.............................. 54

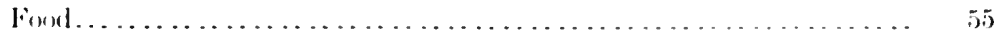

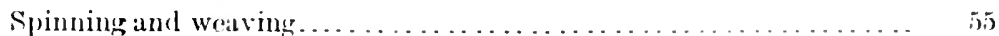

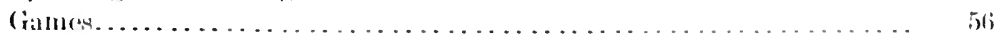

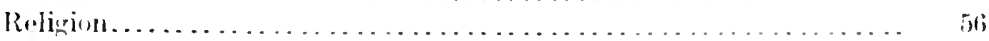

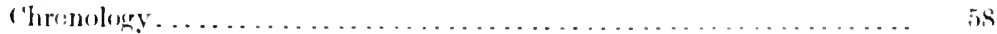

I)

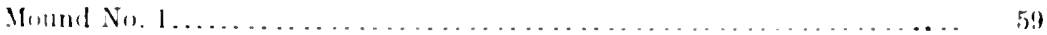

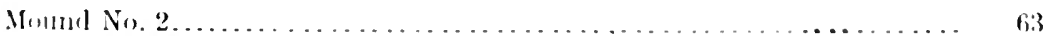

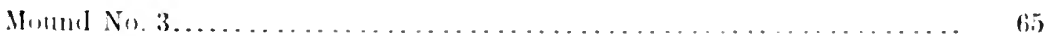

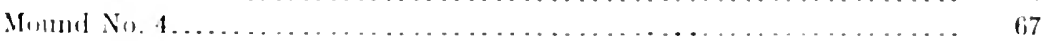

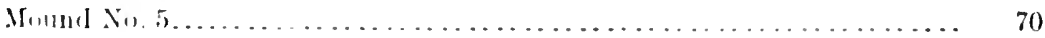


Description of mounds-Continued. Page

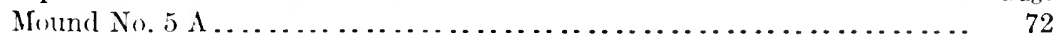

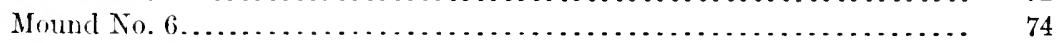

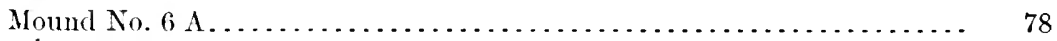

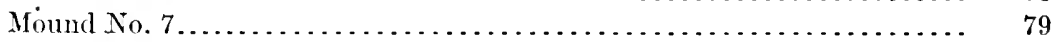

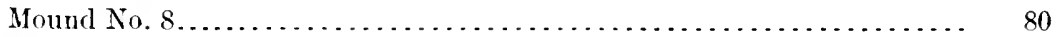

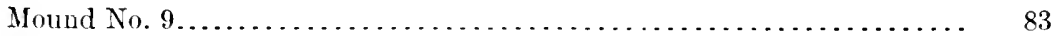

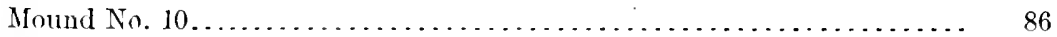

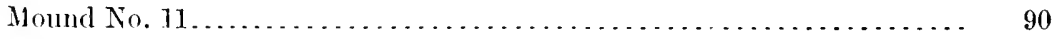

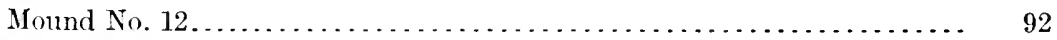

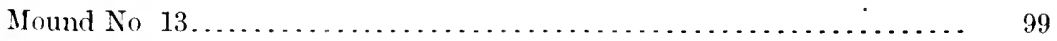

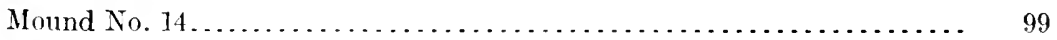

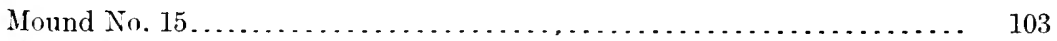

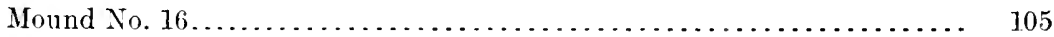

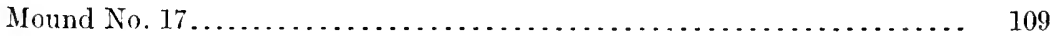

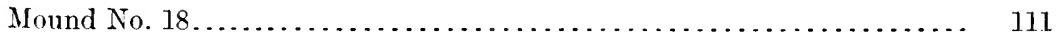

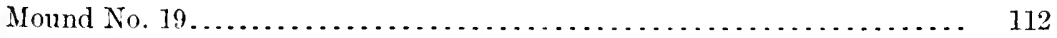

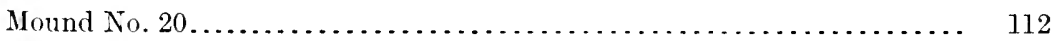

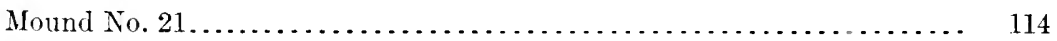

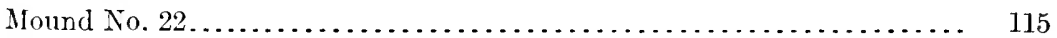

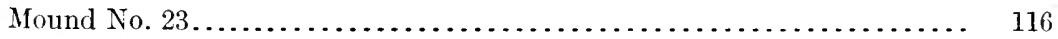

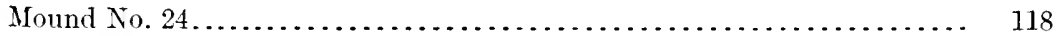

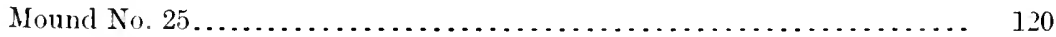

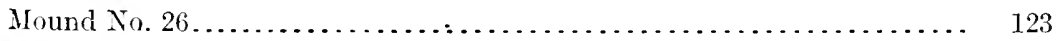

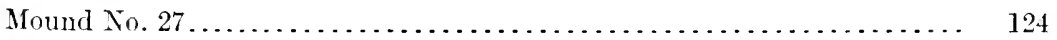

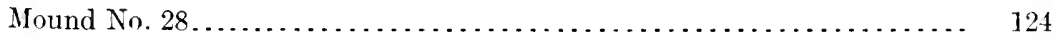

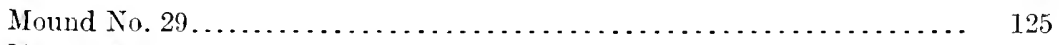

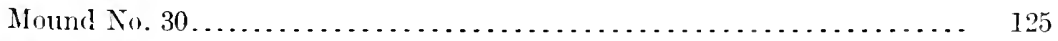

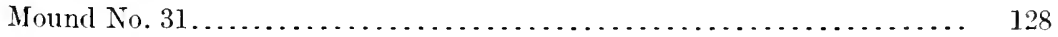

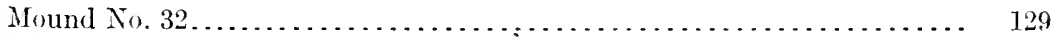

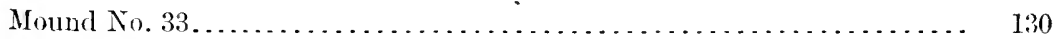

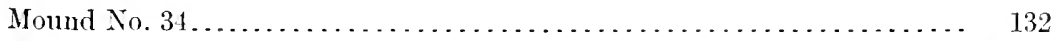

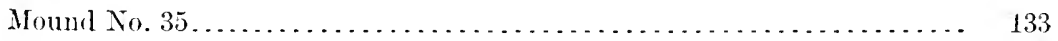

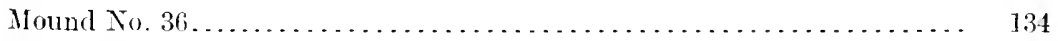

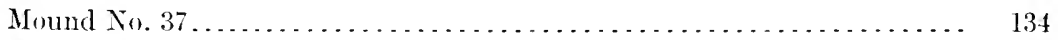

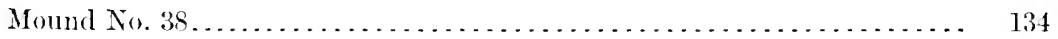

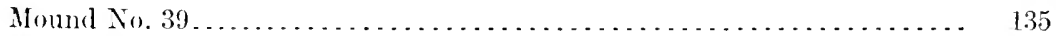

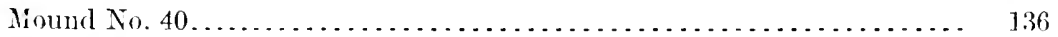

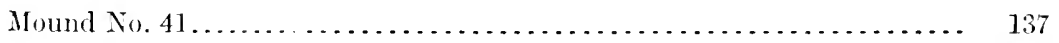

Two painted stucco faces from Uxmal. . . . . . . . . . . . . . . . . . 140

Authorities cited . . . . . . . . . . . . . . . . . . . . . . . . . . 143

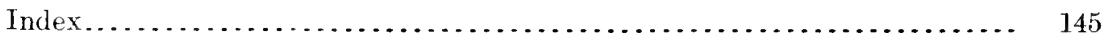




\section{ILLLSTRATIONS}

PlATES Page

1. Group of Santa Cruz Indians. . . . . . . . . . . . . . . . . . . . . 18

2. Maya girls fishing. . . . . . . . . . . . . . . . . . . . . . . . . . . 26

3. Fish drying on one of the rays off the roast of Yucatan. . . . . . . . . . . . 26

4. Maya Indian houses. $a$. Ieaf-thatrhed house. $b$. Indian house on Rio

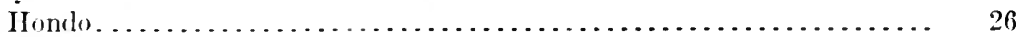

5. Maya woman, 105 years old, spinning cotton. .................. 29

6. Maya loom......................................... 29

7. Sketch map of British Honduras, with aljacent parts of Yucatan and Guatemala, indicating the positions of mounds excavated . . . . . . . . . . .

8. Figuriues of warriurs from Mound $\mathbb{X}_{0} .1 \ldots \ldots \ldots \ldots \ldots \ldots \ldots \ldots \ldots \ldots \ldots$

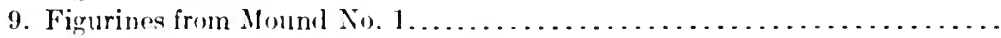

10. a. Section through earthwork inclosing circular space, Santa Rita. b. Secfion of wall through Santa Rita .........................

1]. Egrg-shaped vase from Moind $N_{0} .5 \ldots \ldots \ldots \ldots \ldots \ldots \ldots \ldots \ldots \ldots \ldots \ldots \ldots \ldots \ldots \ldots . . \ldots$

12. Metates and hrazos from Mound $N_{0} .6 \ldots \ldots \ldots \ldots \ldots \ldots \ldots \ldots \ldots \ldots \ldots \ldots \ldots . .75$

13. a. Simall pottery seal. b. Bowl in which skull was found. c. Skull.... 75)

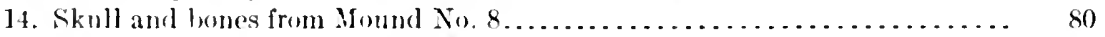

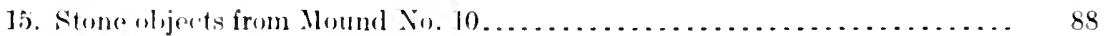

16. a. Muldel of jarleite hivalve sholl. b. Light-green jadeite mask. c. Ax hear!. or cre]t. d. Ferra-cotta rylintler.......................... 91

17. Painted hasin and roser from Mound No. 16..................... 105

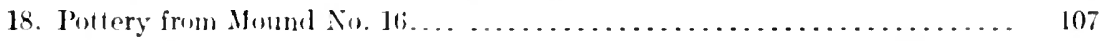

19. a. Deroration on vase shown in figure 60 . b. Decoration of vessel frem

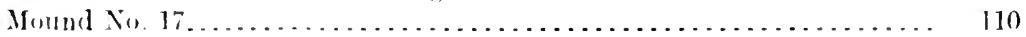

20. Incense burner from Mund No. $24 \ldots \ldots \ldots \ldots \ldots \ldots \ldots \ldots \ldots \ldots \ldots \ldots \ldots \ldots \ldots$

21. a. Sinall vase decorated with human head. b. Human lones from Momml No. 2!.

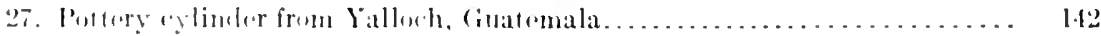

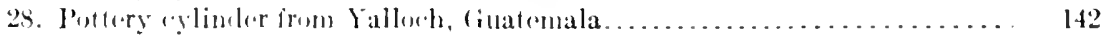

\section{THET FIILRFE}

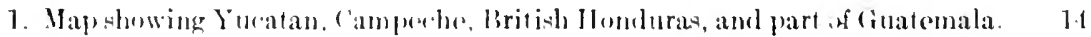

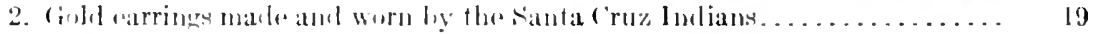

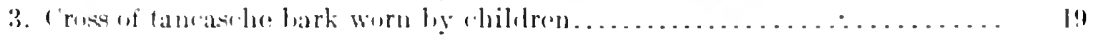

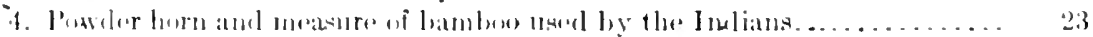

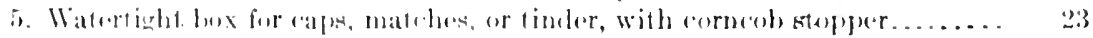

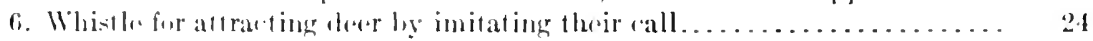


7. Indian carrying load of bejuco, a liana used as rope in house building......

8. Domestic altar.

9. Stonelike sulsstance used to prevent fingers from sticking while spinning.

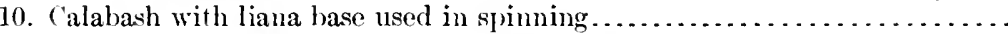

11. ('hichanha Indian priest in front of altar at (ha chac ceremony ............

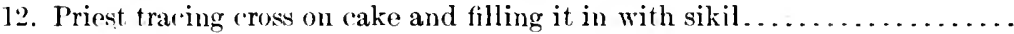

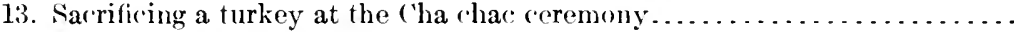

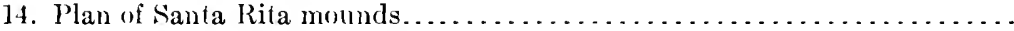

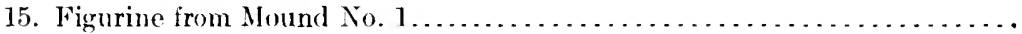

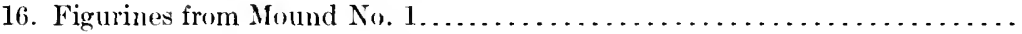

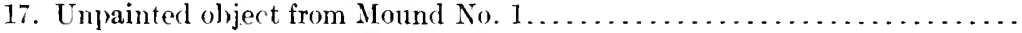

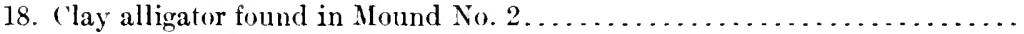

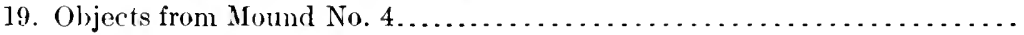

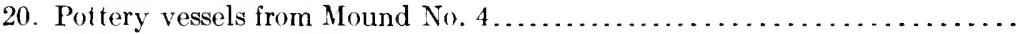

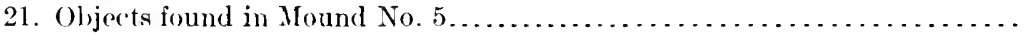

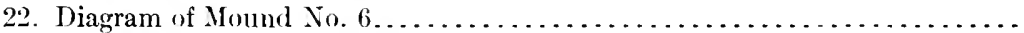

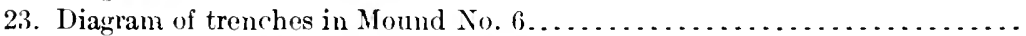

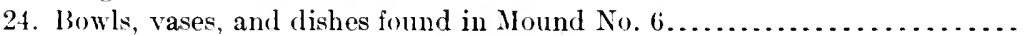

25. a. Skull. b. Limestone foundation. c. Excavation. $d$. Grooved flag in

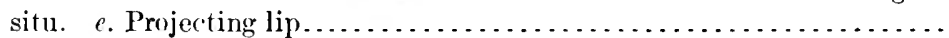

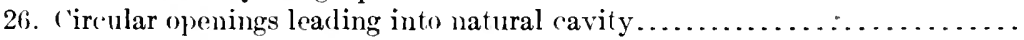

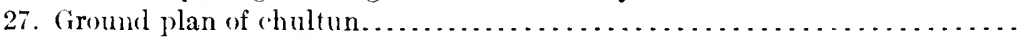

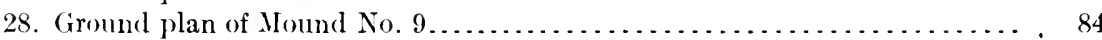

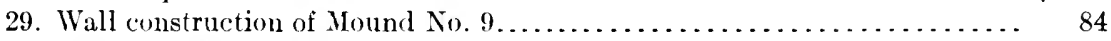

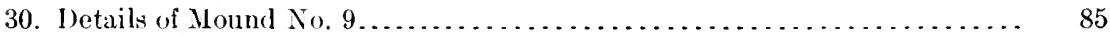

31. Obsidian object and pottery vase from Mound No. $10 \ldots \ldots \ldots \ldots \ldots \ldots . . \ldots 7$

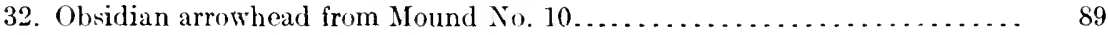

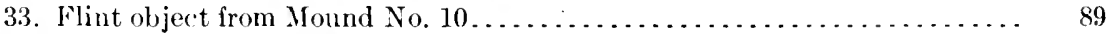

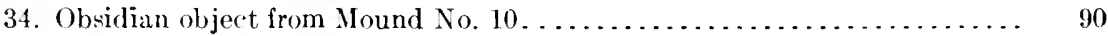

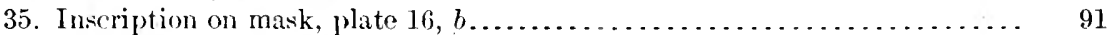

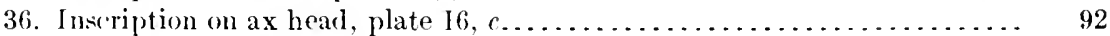

37. Flint spearheads........................................... 94

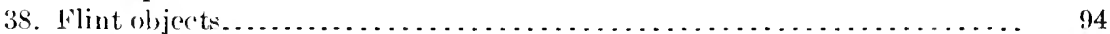

39. Devices scratched on stuceo in aboriginal building . . . . . . . . . . $\quad 95$

40. Eicentrically shaped implenents found at summit of mound . . . . . . . 96

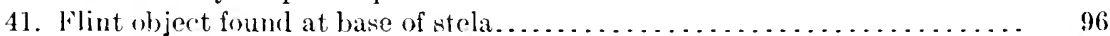

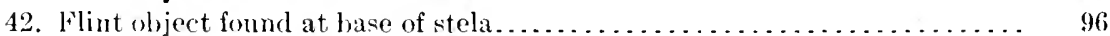

43. Flints found in ruins at Naranjo.............................. 97

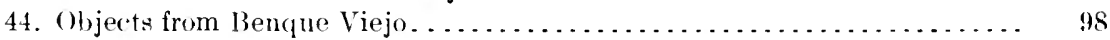

45. Obsidian objects found in a mound near Benque Viejo............... 99

46. Flint object from seven Irills.............................. 100

47. IIorseshoe-shaped flint olject found near San Antonio.............. 100

48. Figure from River Thames, near London..................... 101

49. Flint ol, ject trom Tennessee................................ 102

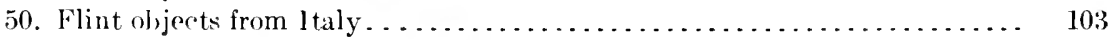

51. Small (up-shaped vase from Mound No. 15..................... 104

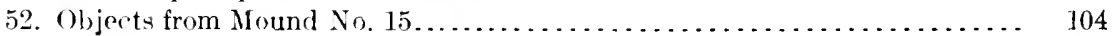

53. Conventionalized representation of bird on vessel shown in plate $17 \ldots \ldots . \quad 106$

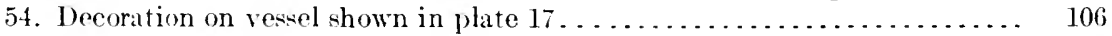

55. Perforated beads found in Mound No. 16...................... 107

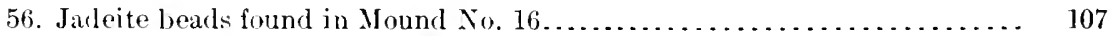

57. a. Circular shell disks from Mound No. 16. b. Greenstone ear plugs from

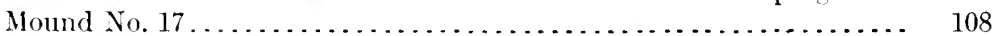

58. Obsidian disk inserted in tooth of skeleton found in Mound No. 17...... 109 
Page

59. Bird carrying a fish outlined on shallow plaque found in Mound No. 17 .. 110

60. Cylindrical pottery vase found in Ifound No. $17 \ldots \ldots \ldots \ldots \ldots \ldots \ldots \ldots . \ldots \ldots$

61. Larger pottery vase found in Mound No. $17 \ldots \ldots \ldots \ldots \ldots \ldots \ldots \ldots \ldots . . . \ldots \ldots \ldots$

62. Coiled plumed serpent painted on plaque found in Mound No. 17. . . . 111

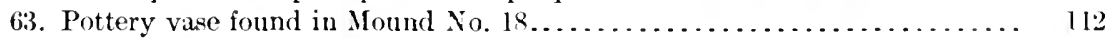

64. Glyph outlined on outer surface of rim of vase shown in figure $63 \ldots \ldots \ldots$ 112

65. Torso, head, and headdress from $M$ Ifound No. $20 \ldots \ldots \ldots \ldots \ldots \ldots \ldots \ldots . . \ldots \ldots$

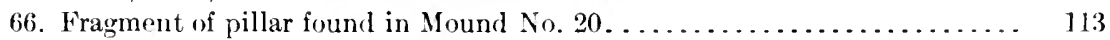

67. Another view of incense burner shown in plate $20 \ldots \ldots \ldots \ldots \ldots \ldots \ldots . . \ldots 119$

68. Incense burner decorated with crude clay figurine from Mound No. 25... 120

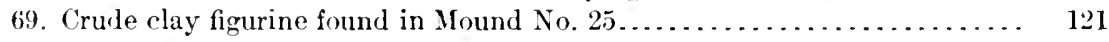

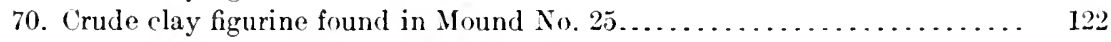

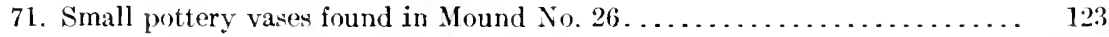

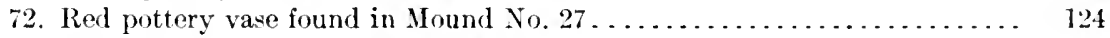

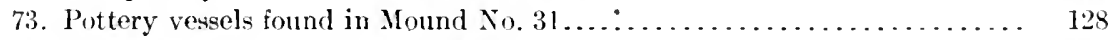

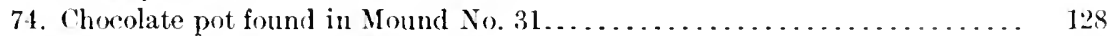

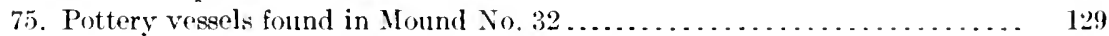

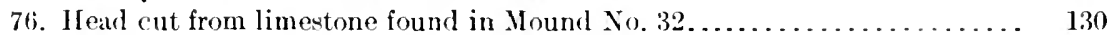

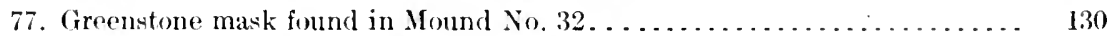

78. Soapstone lamp found in Mound No. 33...................... 131

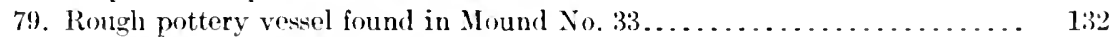

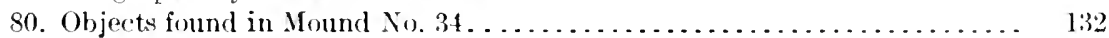

81. Figure in diving porition on small vase.......................... 133

82. Design incised on femur of deer found in Mound No. 39.............. 135

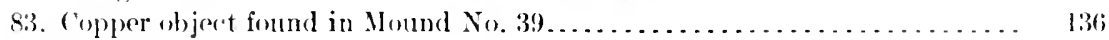

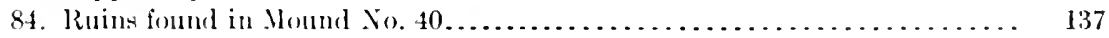





\section{KEY TO PRONUNCIATION OF MAYA WORDS}

Vowels and consonants are pronounced as in Spanish, with tho following exceptions:

$k$......k explosive

K......ordinary palatal $k$

X......sh as in shut

Ts.....th explosive

().......ts

Ai..... Iike $i$ in confide

tt.....t explusive 



\title{
THE MAYA INDIANS OF SOUTHERN YUCATAN AND NORTHERN BRITISII HONDURAS
}

\author{
By 'Tuomas W. F. GaNN
}

PART 1. CUSTOMS, CEREMONIES, AND MOIE OF LIFF

\section{IN'TRODUCTION}

The southem and eastern parts of Yucatan, from Tuluum in the north to the Rio Hondo in the south, are occupied to-day by two tribes of Maya Indians, the Santa Cruz and Icaichè or Chichanhà. The number of Santal Cruz was estimated by Sapper in 1895 at about 8,000 to 10,000 , but at the present day has probably been reduced to about 5,000. 'The Icaichè, the number of whom he estimated at 500 , and is given by the Guia de Yucatan in 1900 as 803 , now comprise not more than 200. 'This decrease is due to the policy of extermination carried out among the Santa Cruz for years by the Mexican Government, and the consequent emigration of many of the Indians to British Honduras, Guntemala, and northern Yucatan. The northern and western parts of British Ilonduras contain between 5,000 and 6,000 Indians; these in the north are partly indigenous and partly immigrants drawn from Yucatean tribes who have left their homes after various political disturbances, especially after the oceupancy of their towns of Bacalar and Santa Cruz by the Mexican Government. The Indians of the western part of the colony are ulso partly indigenous, but for the greater part It zas, who have come in from looten in Guatemala.

The objerts shown in figures $16,17,18,19,21,31,35,36,47$, $51,52,55,56,57,59,62,63,64,65,69,70,76$, and 75 , and in plates s, 11,12, 13, 14, 15, 16, 17, 1 sa, and 19 are in the Jiverpool Musem: these shown in figures 15,40 , and 41 and in plate 9 are in the British Musemom; these shown in figure 45 and in plates $23,24,25,26,27$. and 28 are in the Bristol Musemom; and those shown in figures 67 and 6 and in plat es 20,21 , and 22, are in the Duseum of the American Indian, Heye foundation. 


\section{HIABITAT}

The northern part of British Honduras, between the Rio Hondo and the Rio Nuevo, consists of an almost level plain, having an area of nearly 1,000 square miles. The soil is a vegetal humus, varying from a fow inches to several feet in depth, the average depth being about 2 feet; beneath this is a stratum of marly limestone, outerops of which are found in many places. The southern part of Yucatan, which, unlike the northern part, is comparatively well watered, is also flat, though a few small hills are found along the northem bank of the Rio IIondo, commeneing about 50 miles from

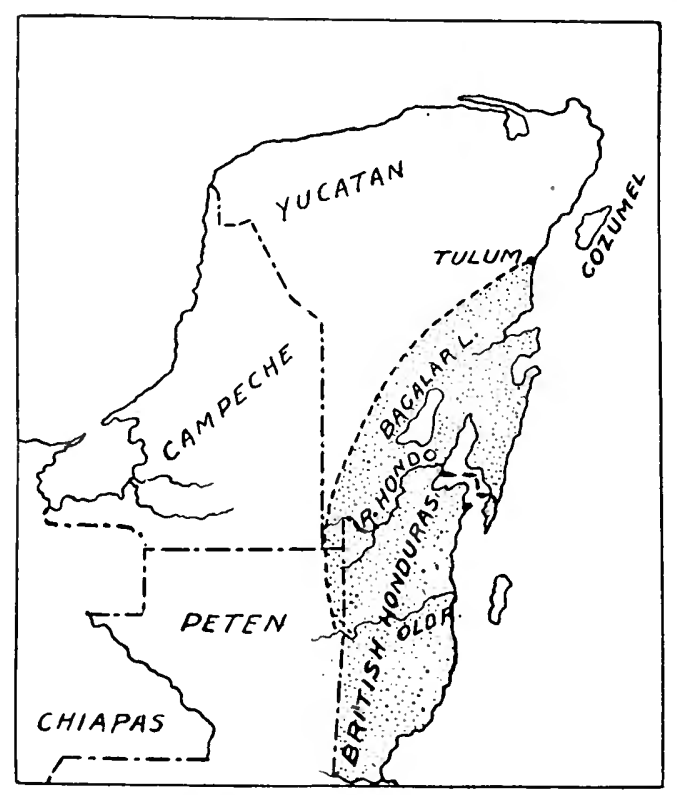

FIG. 1.-Map showing Yucatan, Campeche, British Honduras, and part of Guatemala. The area dealt with is shaded. its mouth (fig. 1). Most of the land along the rivers is swampy, producingonly reeds, coarse grasses, and mangrove trees. Beyond the swamp country are found "cuhum ridges," consisting of river valleys or depressions in the surface which have become filled with alluvium brought down by the rivers from the interior, forming an exceedingly rich soil suitable for the cultivation of maize and nearly every tropical product. It is upon these "cuhun ridges" that most of the mounds and other relics of the ancient inhabitants are found and that nearly all the villages of the modern Indlians are built. Large tracts of what is known as "pine ridge" are saittered throughout this area; these are level or slightly undulating plains covered with gravel and coarse sand-exceedingly poor soil, producing only wiry grass, yellow pines, and small pimento palms. On these "pine ridges" Indian mounds are hardly ever found, nor do the Indians of to-day build villages upon them except in rare instances and for special local reasons. With the exception of the extreme northern part, nearly the whole of this area is well watered by rivers and streams, while scattered throughout it are numerous lagoons and lakes, the largest of which is the Bacalar Lagoon. 


\section{PERSONAL CIIARACTERISTICS}

The manners, customs, religious conceptions, and dally life of all these Indians are very similar, though among the Indians of British Honduras, who come more closely in contact with outside influences, old customs are dying out, and old ideas and methods are being superseded by new. The langunge of the tribes here considered, with slight local dialectical variations, is the same; all are of the same physical type; in fact, there can be little doubt that they are the direct descendants of those Maya who occupied the peninsula of Yueatan at the time of the conquest. Physically, though short they are robust and well proportioned. The men average 5 feet 2 inches to 5 feet 3 inches in height, the women about 2 inches less. The skin varies in color from almost white to dark bronze. 'The hair of both sexes is long, straight, coarse, black, and luxuriant on the head, where it extends very low over the forehend, but is almost entirety absent from other parts of the body. The women usually wear their hair hanging down the back in two plaits. Their facces are round and full, with rather high cheek bones; the skull is highly brachicephalic in type. 'The following indices were taken from a small number of Santa ('ruz Indians, mostly males of middle age:

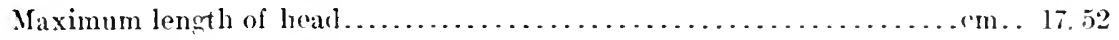

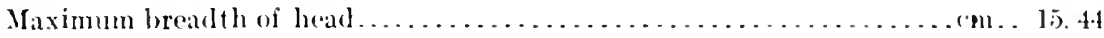

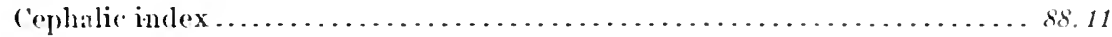

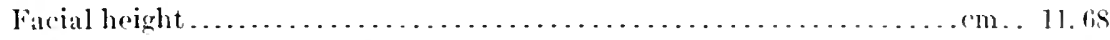

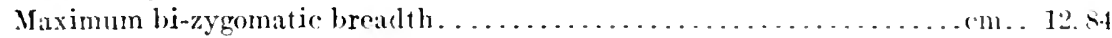

Farial index . . . . . . . . . . . . .

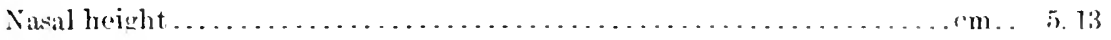

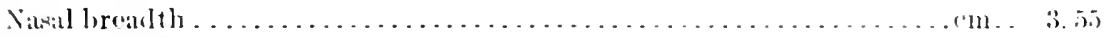

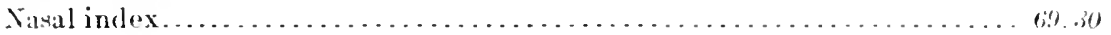

The eyes are bargo and dark brown, the enrs small and elosely applied to the head, the nose rather broad, and the jaw mounathous. The mouth is fairly large and the teeth excellent, though toward midde une they become greatly worn down in muny individuals front anting corn cako impregmatod with grit from the stone metate, and from the samecause they are frequently much incerusted with tart ar. 'The figure in both soxes is short and broud. The long bones and the extremities are smatl and delicate. Both men and women are, howrere, rapable of considerable and prolonged exertion. The former can carry londs of 150 pounds for 20 miles in the macupal (tab), a netted bug 
which is slung over the back and held up by a band passing round the forehead, white the latter can work for hours at a time grinding corn on the metate without apparent fatigue. Many of the younger women would be considered very good looking, measured by the most exacting standard, though they reach maturity at an early age, and deteriorate in appearance very rapidly after marriage, the face becoming wrinkled and the figure squat and shapeless. In walking the men bend the body forward from the hips, keep the eyes fixed upon the ground, and turn the toes in, habits acquired from carrying the macapal on all occasions. So accustomed have they become to this contrivance that many of them, when starting on a journey of even a couple of miles, rather than go unloaded, prefer to weight the macapal with a few stones as a counterpoise to the habitual forward inclination of their bodies above the hips. Children begin carrying small macapals at a very early age, and it is probably to this habit and not, as Landa suggests, to the custom among the women of carrying their children astride the hip that the prevalence of bowlegs $(k \bar{u} l b a \bar{o} k)$ among the Indians is due. These people have a peculiar and indescribable odor, rather pleasant than otherwise; it is not affected by washing or exercise, is much stronger in some individuals than in others, and is perceptible in both sexes and at all ages. The women are, on the whole, both physically and mentally superior to the men, and when dressed in gala costume for a "baile" with spotlessly clean, beautifully embroidered garments, all the gold ornaments they possess or can borrow, and often a coronet of fire beetles, looking like small electric lamps in their hair, they present a very attractive picture. They are polite and hospitable, though rather shy with strangers; indeed in the remoter villages they often rush into the bush and hide themselves at the approach of anyone not known to them, especially if the men are away working in the milpas. They are very fond of gossip and readily appreciate a joke, especially one of a practical nature, though till one gets to know them fairly well they appear dull and pllegmatic. When quarreling among themselves both women and girls use the most disgusting and olscene language, improvising as they go along, with remarkable quick-wittedness, not binding themselves down to any conventional oaths or forms of invective, but pouring out a stream of vituperation and obscenity to meet each case, which strikes with unerring fidelity the weak points in the habits, morals, ancestry, and personal appearance of their opponents. The young girls are as bad as, if not worse than, the oller women, for whom they seem to have no respect. They are extremely clean in their persons, and wash frequently, though with regard to their homes they are not nearly so particular, as hens, logs, pigs, and children roll about together promiscuously on the floor, and fleas, lice, and jiggers abound only too frequently. 
The description given by Landa (chap. xxxir, p. 192) of the Indian women at the time of the conquest applies equally well to their descendants of the present day:

Emborachavanse tambien ellas con los combites, aunque por si, como comian por si, y no se emborachavan tanto como los hombres ... Son avisadas y corteses y conversables, eon que se entienden, y a maravilla bien partidas. Tienen poco secreto y no son tan limpias en sus personas ni en sus cosas con quanto se lavan como los ermiños.

The women are rery industrious, rising usually at 3 or 4 o'clock in the morning to prepare the day's supply of tortillas or corn cake. During the day they prepare tobacco (kutz) and make cigarettes; gather cotton (taman), which they spin (kuch), weare (sakal), and embroider for garments; weave mats of palm leaf and baskets (xush) of a variety of liana $(a k)$; make pottery $(u l)$, and cotton and henequen cord, of which they construct hammocks ( $k$ an). In addition to these tasks they do the family cooking and washing, look after the children, and help their husbands to attend to the animals. Till late at night the women may be seen spinning, embroidering, and hammock-making by the light of a native candle or a small earthenware cuhoon-nut oil lamp, meanwhile laughing and chatting gnyly over the latest village scandal, the older ones smoking cigarettes, while the men squat about on their low wooden stools outside the house gravely discussing the weather, the milpas, the hunting, or the iniquities of the Alcalde. Among the Indian women of British Honduras the old customs are rapidly dying out; spinning and waving are no longer practiced, pottery making has been rendered unnecessury by the introduction of cheap iron cooking pots nnd earthenware, candles have given place to mineral oil lamps, and even the motate is being rapidly superseded by small $\Lambda$ merican hand mills for grinding the corn. 'The men's time is divided between agrieulture, hunting, fishing, and boat and house building, though at times they undertake tasks usually left to the women, as mat and basket making, and even spinning and weaving. The Indinns of British Honduras who live near settlements do light work for the runcheros and woodeutters; they have the reputation of being improvident and lazy, and of leaving their work as soon as they have acequired suflicient money for their immediate noeds, and this is to some extent true, as the Indian always wants to invest his cash in something which will give an immediate return in plensure or anmsement. The men are silent, though not sullen, very intelligent in all matters which conecrn their own daily life, but singularly incurions as to anything groing on outside of this. They are civil, obliging, and rood-tempered, and make cxecllent servants, when they can be got to work, but appear to be for the most part utterly lacking in

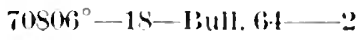


ambition or in any desire to accumulate wealth with which to acquire comforts and luxuries not enjoyed by their neighbors. It happens occasionally that an individual does perforce acquire wealth, as in the case of the head chief of the Icaichè Indians, who was paid a salary by the Mexican Government to keep his people quiet, and royalties on chicle cut on his lands by various contractors. He accumulated a considerable sum, all in gold coin, which he stored in a large demijohn and hid in the bush. At his death, as no one knew the place where the demijohn was buried, the money was permanently lost. They are remarkably skillful at finding their way in the bush by the shortest route from point to point, possessing a faculty in this respect which amounts almost to an instinct; they are skilful also at following the tracks of men and animals in the bush by means of very slight indications, as broken twigs and disturbed leaves, imperceptible to an ordinary individual. The men are very stoical in bearing pain. I have removed both arms at the shoulder joints, with no other surgical instrument than a long butcher's knife, and no anesthetic except several drinks of rum, for an Indian, crushed between the rollers of a native sugar mill, without his uttering a single complaint. The Indians are undoubtedly cruel, but not wantonly so, as the shocking acts of cruelty reported as being perpetrated by them from time to time are usually by way of reprisal for similar or worse acts on the part of the Mexicans. Before the rising of the Indians in 1848, they were throughout this part of Yucatan practically in a state of slavery, and were often treated by their Spanish masters with the utmost barbarity. As an instance of this it is recorded of a well-known merchant of Bacalar that he was in the habit of burying his Indian servants in the ground to the neck, with their heads shaved, exposed to the hot sun; their heads were then smeared with molisses and the victims were left to the ants; and this punishment was inflicted for no very serious offense. It is hardly to be wondered at that such treatment left in the Indians' hearts an undying hatred for their masters which, when in their turn they gained the ascendancy, found vent in acts of the most horrible cruelty-flogging, burning, mutilation, and even erucifixion.

\section{Dress}

The men wear hats of platted palm leaf, which they make theinselves; those woven from coarse split palm leaf are known as xani pok, those of very fine leaf, like Panama hats, bear the name bomi pok (pl. 1). They wear cotton trousers (eex), or in some sections short cotton drawers (xkulex), with a short, loose, shirt-like jacket of cotton hanging outside the trousers. On the feet they use sandals of danta hide (xanapkeuel) held in place by a leather or henequen thong passing between the great and second toes and around the 


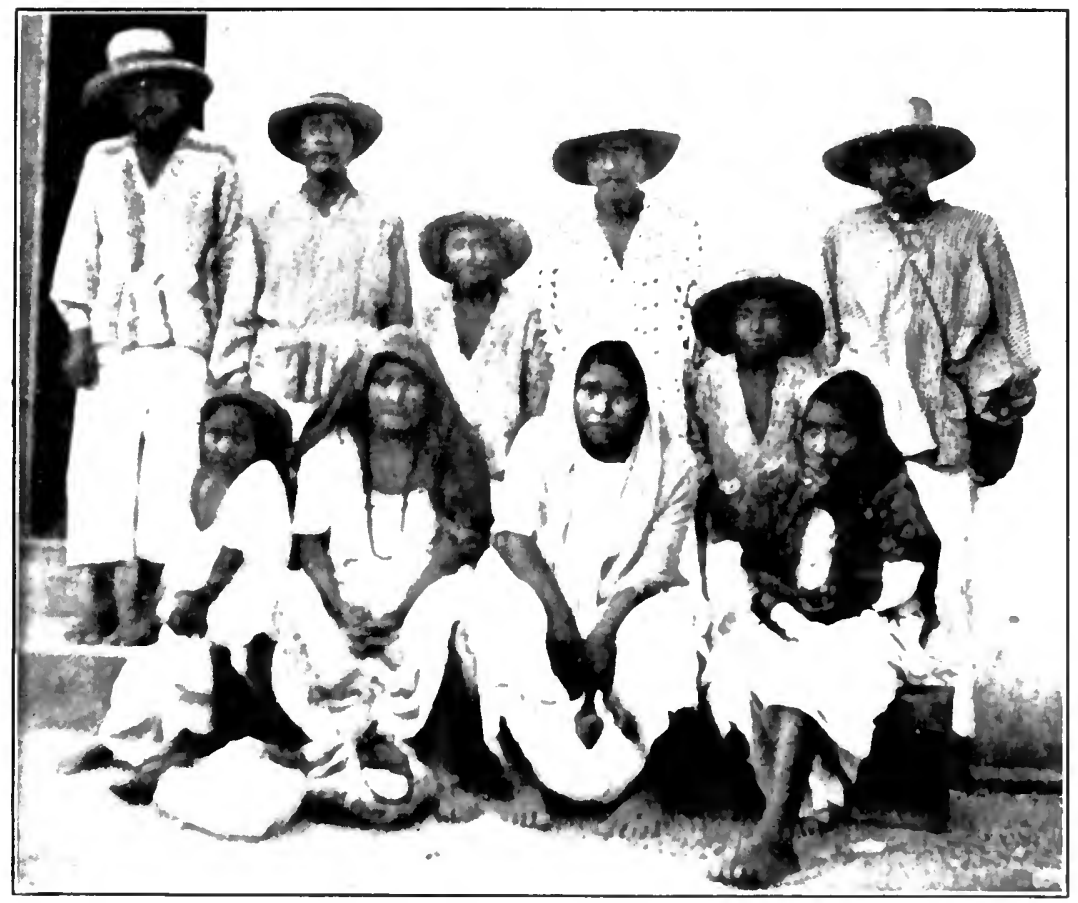

GROUP OF SANTA CRUZ INDIANS 

back of the heel to the front of the instep, where it is fastened. Formerly the cotton was grown, spun, and woven at home, but nowadays it is giving place to cheap imported English and American goods, while the sandals are being superseded by moccasins and even by imported shoes. The moccasins the Indians make themselves, tanning the hides (usually of deer or antelope) in lime and red mangrove bark and stitching the parts together with thin strips of leather. These moccasins, which are made on crude wooden lasts, are very comfortable and wear well.

The women wear two garments of cotton; the huipil (yuptè), a loose short-sleeved blouse, cut square at the neck, and reaching nearly
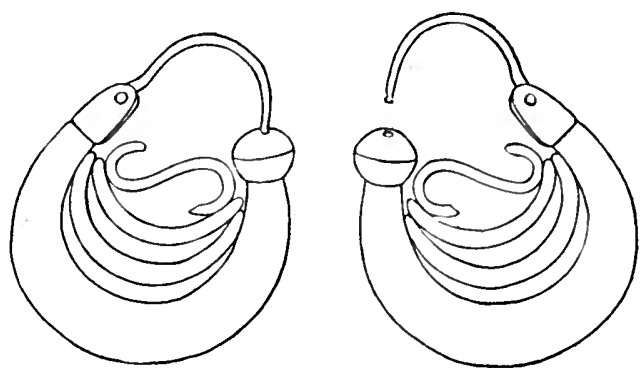

Fig. 2.-Gold earrings made and worn by the Santa Cruz Indians. to the knees, and a short skirt reaching to between the knee and the ankle, known as a pik. The neck, the lower border, and the armholes of the blouse and the edge of the skirt were formerty beautifully embroidered in varicolored floral and geometrical devices: now, however, cotton manufactured in England or the United States and stamped in colors to imitate the original embroidery is rapidly coming into use. The women formerly went barefooted or wore loose slippers; now they frequently wear imported shoes, often with high heels, a feature which renders their walk and (arriage awkward and stilted. They often go barcheaded, but sometimes wear a sort of shawl (bostch) around the head and shoulders. Many of them wear large round or oval plaques

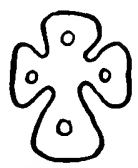

Fig. 3.- Cross of tinrasche lark worn by chiluren. of gold (tup) in the cars, survivals, probably, of the cnormous round ear disks worn by the anciont Maya (fig. 2). Some of the women wear long gold chains, with religions molallions at tached, while the smaller children wear a varicty of curious objects, as small coins, shells, beads, dried soeds, and berries, with figurines in wood, stone, pot tery, and metal, strung round their necks. Many of these are worn as charms or amulets to proteet the weirer anainst discalses, aceidents, or evil spirits, or to bring grood luck. A charm worn by nearly all children consists of a small cross of tencosiche bark (figr. 3) which is recrarded as a sovcresign remedy for flatulenere, a complanint from which, owing to the nature of their diet, nearly all sufler. 


\section{INdustrial. Activities}

\section{AGRICULTURE}

Of all the arts practiced by the Indian, agriculture is by far the most important: indeed the greater part of his time and labor are devoted to the milpa $(k \circ)$, or corn plantation, which affords him his principal means of livelihood, for if the corn crop fails he knows that actual starvation will menace his family until the next crop is gathered. The virgin bush, in which the milpa is made, is cut down about December or January, only the large and hardwood trees being left standing. This is the most arduous part of the work, and the neighbors often assist in it, being helped in turn when making their own milpas. The bush is allowed to clry until the end of May (the dry season lasting from January to May), when it is burned off. After the burnt area has been cooled by the first shower of rain it is planted in corn (ixim). 'This is a simple operation, two or three men going over the ground, each with a bag of corn and a sharp-pointed stick, making small holes at fairly regular intervals, into each of which they drop a few grains of corn, and then cover them with earth. About October the corn begins to ripen, whereupon each stalk is bent about a foot below the ear and allowed to hang down for several days in order that rain may not gain entrance and spoil the grain in the final stages of ripening. During this period the owner spends nearly all his time in the milpa, sleeping there in a little palm-leaf shack at night, since many animals, as deer and wild hogs, are very fond of corn, which is subject to raids also by neighboring Indians and by tame pigs from the village. When the corn is ripe, it is stored, still in the husk, upon a low platform, in a small honse specially built for the purpose, of ten, in order to avoid transportation, situated within the milpa. It is shelled as required for use, the surplus from that eaten by the family and stock being exchanged at the nearest village for eash or for cotton cloth, rum, iron cooking pots, ammunition, and other luxuries. The shelling is done by rubbing the husked ear against a rough flat surface, made by binding a number of comeobs (bacal) together into a circle with liana. Many fruits and vegetables besides corn are grown in the milpa, including yams (xaci macal), eamote ( $\bar{\imath} s$ ), pumpkins (kuum), squashes (xka), tomatoes (paak), plantains (haz), colalu (xtrhoch), aguacate (on), plums (abal), oranges (pakaal), siricote (kopte), sapolillas (ya), mamai (chacal haz), okra, garclen egg, melon, breadfruit, sweet lime, pineapple, and a variety of others. 


\section{PROCURING FOOD; COOKING}

Both men and women take for the first meal of the day a hot thick drink known as posol, made from ground corn and water, often flavored with honey; later they eat tortillas, beans, and chili pepper, accompanied with a cold drink made from corn. In the evening they make their principal repast, which includes game, pork, fish, or eggs, with beans and other vegetahles, plenty of chili pepper, and either chocolate or some hot drink made from corn. They use a great variety of drinks concoeted of ground maize and water, including chocosacan, a solution of the masa from which tortillas are made, in water, flavored with a little salt; pinol, a solution of ground tousted corn seasoned with pimento and other spices; posol, boiled corn ground to a paste and mixed with hot watcr; sacha, very much like posol, but the corn is not cooked soft, so that the beverage is gritty; and, lastly, atol, which is chocosacan boiled till the mixture becomes thick and glutinous.

Tortillas, or corn cake, sometimes eaten hot, sometimes cold, and at times toasted, are the Indian's chief mainstay in the way of food, as they appear at every meal, and at a pinch he can exist on them alone for a very long period. Tortillas are made in the following way: The grain is first soaked overnight in a lye of wood ashes, treatment which softens the grain and loosens the outer husk. The softencel grain is next ground into a fine paste on an oblong stone, slightly concave, known as a metate (kill), by means of a stone rolling pin thicker in the middle than at the cuds, designated as a brazo ( $u$ kabka). This procedure takes considerable time, as the grain has to be ground a number of times in order to get the paste to the required degree of fineness. When the paste or masa is realy it is flattened hy hand into small round cakes (tortillas), which are baked on an iron or earthen plaque (xamach) over a glowingr wood fire.

The lunters are experts at barbecuing (macan) the carcasses of valdous birds and animals, chiefly deer, peceary, wild turkey, and curasisow, an they often get a large supply of game when several days' journey from the village, which, unless preserved in somo way, would quickly spoil. The carrasses are cut inte joints; the birds plueked, reloned, and split open; and the ment thus prepared is lume in a small palm-loaf shack rendered as nearly airtight as possible, upon the floor of which is kindled a fire of damp cedar chips. These rive off some heat and great quantities of arombitic smoke, so that in about 2.4 hours the ment is sufliciently cured to last for several works. Ment prepared in this way is considered a great delieary. If it is wished to preserve the meat for lonerer prepiods the processis is prolonged and salt may be rubbed in. Strips of meat 
and carcasses of birds may sometimes be seen hanging from the rafters over the fire in the kitchen so desiccated, hard, and blackened that it would appear impossible to eat them; but after months of drying this meat, when soaked in warm water for 24 hours, is not unpalatable. The Indians wash their hands before and after eating, a very necessary practice, as they eat exclusively with their fingers, using the tortillas to scoop up gravy, beans, and other mushy foodstuffs. They eat at small round tables about 16 inches high, sitting, or rather squatting, around them on little blocks of wood 4 to 5 inches high. They are very fond of salt, which anong the coast Indians is obtained by evaporating sea water, among the inland villages by trade from Yucatan and Guatemala. Since this supply has been almost cut off, owing to the troubles with Mexico, the Indians frequently use for salt the ashes obtained by burning botan tops. Men and women do not eat together, as the women are preparing relays of hot tortillas for the men while the meal lasts. Their food and mode of eating is well described by Landa (chap. xxI, p. 120):

Que por la mañana toman la bebida caliente con pimienta, como esta dicho $\mathrm{y}$ entre dia las otras frias, y a la noche los guisados. Y que si no ay carne hazen sus salsas de la pimienta y legumbres. Que no acostumbravan comer los hombres con las mugeres, y que ellos comian por si en el suelo, o quando mucho sobre una serilla por mesa: y que comen bien quando lo tienen, y quando no, sufren muy bien la hambre y passan con muy poco. Y que se lavan las manos y la boca despues de comer.

Indeed, the foregoing description would apply almost as well to Indians of the more remote villages of the present day as to those of the time immediately after the conquest. In localities where they have come in contact with more eivilized communities their menu has been considerably enlarged by the introduction of imported foodstuffs, while their methods of eating have been changed by the introduction of knives, forks, and spoons. The native methods of cooking are very primitive. Three large flat stones so placed as to form an equilateral triangle, known as koben, form the only fireplace; in this is kindled the fire of sticks or split logs, over which is placed the earthenware or iron cooking pots or plaque for baking tortillas, resting on the stones. Fire (kaak) is usually obtained through the use of matches among the Indians of British Honduras. Hunters and others who spend a great part of their time in the bush employ flint and steel. Among the Indians in the remote villages fire is still made by swiftly rotating a sharp-pointed shaft of some hardwood (usually dogwood) in a hole made in a small slab of very light dry wood (commonly gumbo limbo). There is no chimney to the kitehen, the smoke finding its way out as best it can through the doors and crevices in the walls; consequently 
the whole of the interior, with its permanent furnishings, is colored a fine rich brown.

\section{IIUNTING}

It must be admitted that the Indian is no sportsman in the pursuit of game, the claims of the pot being always paramount. He rarely shoots at a flying bird unless to fire into the midst of a flock of parrots or wild ducks, and when after the larger game he waits till he can deliver the contents of his gun point-blank into some vital

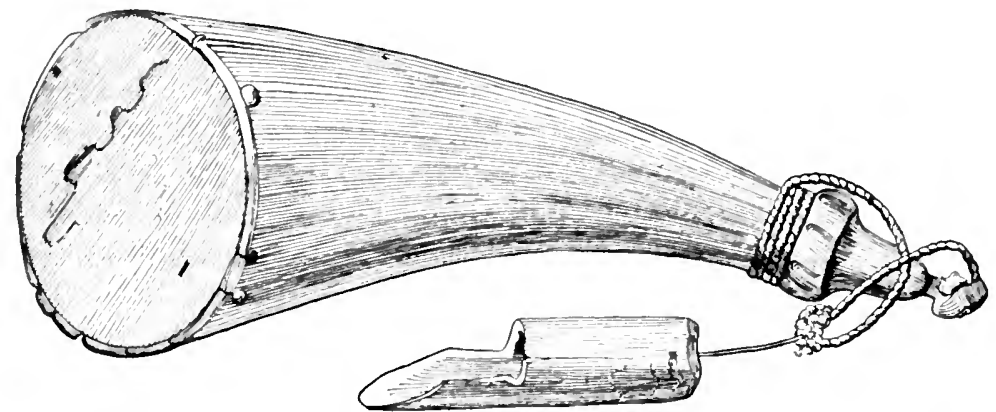

Fic. 4.-Powder horn and measure of bamboo used by the Indians.

part. This practice may be lue partly to the limitations of his weapon, which till recent years consisted of a muzzle-loading section of gas pipe, nearly as dingerous when discharged to the hunter as to the crame, and partly to the fact that the bush is usually so dense that an animal, if not shot at point-blank range, can not be gotten at all. It is probably not more than four generations since the use of the bow and arrow died out among the Indiuns in the western part of British Honduras, as old men nunong them

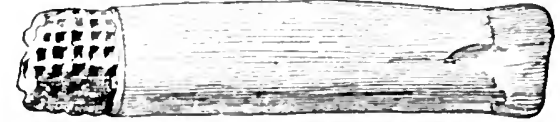

Fic. 5. Watertipht box for caps, matches, or tinder, with corncol) stopper.

have tohl me that they could remember seceing a fow still in use when they wore very young. The flint arrowhends, they said, were obtained lown the Vopan River. This seems quite possible, as at Bakeres, not far from Bolize, there is an outcrop of flint, where, judgring by the great heaps of fresh-looking ethips and rejects still in existence, a considerable "factory" must have existed at a comparativety rerent date. Some of these old men eould still make fairly servienable bows and arrows, the heads of the latter being cut from hardwood. 
The principal game animals of this region are the deer (ke), two species of wild hog, the warri and peccary (kekem), gibnut (halib), armadillo (vetsh), wild turkey (kutz), parrot (tut), pigeons of various kinds (mucui), curassow (kambul), quam (cosh), quail (num), and partridge (mankolom). Besides these, birds in great variety, reptiles, and mammals are killed and eaten from time to time, including plovers, garzas, toucans, water hens, wild ducks, and chichalacas. The iguana (tolok) is eaten by the Indians in the west of British Honduras, as are also the woula (ochkan), a large constrictor snake, and the rattlesnake, known as the cazon $i$ kash, or "little shark of the woods." Turtles (sacak) are often captured along the east coast of Yucatan and the adjacent islands, and their eggs in the breeding season form a great delicacy for the Santa Cruz Indians living in the neighborhood of Tuluum. Hicatee $(a k)$ and bucatora are caught in great numbers in all the rivers and lagoons. The tiger (balam), puma (coh), picote (chic), monkey (maash), tapir (tzimin), squirrel $(k u u k)$, cane rat $\left(t s_{0}\right)$, and other animals are hunted from time to time, either for their skins or flesh. Deer are secured in considerable numbers in the rutting season by imitating their call with a wooden whistle (fig. 6); they are also found in the milpas, just after the burning,

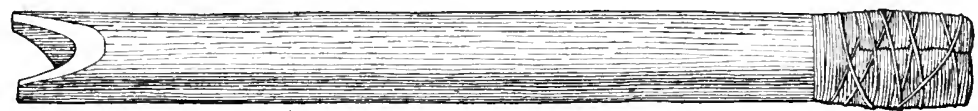

FIG. 6. - Whistle for attracting deer by imitating their call.

where they come to lick the slightly saline ashes. At this time the owners build platforms on poles 10 to 12 feet high, on top of which they spend the whole night in an extremely cramped and uncomfortable position, waiting for deer or other game to approach near enough for an easy shot. A favorite method of hunting the larger game animals is to go out at night with a split-pine torch attached to the hat; this attracts aninals of all kinds, whose eyes may be seen gleaming in the dark, affording an easy mark, though not infrequently a neighbor's errant pig pays the penalty of curiosity.

Traps of two kinds are in common use. One employed to snare larger game is constructed in the following way: A path frequented by game in going to and from a watering place is found; along this is dug a shallow trench opposite a good springy young sapling; two stakes are driven in, one on each side of the trench, the one farthest from the tree being crooked at the top. A piece of henequen cord, provided with a noose at one end, and with a stick long enough to extend from one stake to the other, firmly tied by its middle abore the noose, is attached to the top of the sapling by its other end. The sapling is then bent down and held in place by the stick above the noose, which is fixed lightly between the crook in one stake and 
the stake opposite to it, the loop hanging suspended between the two. Lastly, a number of sticks and leaves are scattered lightly over the trench and beside the stakes and loop. Animals coming along the run are very apt to put their necks in the loop, and by pulling on this, to release the cross stick, whereupon they are immediately suspended in the air by the jerking back of the bent sapling. Animals of all sizes, from rabbits to tigers, are caught in traps of this kind, the strength and adaptability of which vary with the size of the bent tree and the adjustment of the noose. Another trap, used only for small animals, consists of an oblong cage made of split bamboo or cabbage bark. Over the opening, which is in the top, rests an accurately balanced strip of board, baited at one end with corn. When the animal endeavors to reach the bait it is precipitated into the trap, and the board swings back into place, covering the exit. Before they obtain guns the boys use slings, with which they can throw pebbles with remarkable force and accuracy, bringing down birds, squirrels, and other small game. They keep many tame animals, some for food, others as pets, including pigs, dogs, cats, peccaries, gibnuts, rabbits, quashes, nicos de noche, and squirrels; also birds, as parrots, doves, quam, curassow, chichalaca, sinsonte, pavo real, and many others.

\section{FISHING}

Many fish are found in the coastal waters, in the rivers, and in the lagoons of the interior, including cazones, tarpon, skipjacks, snappers, ecls, haracoulas, stone hass, cobarli, jewfish, tubers, bay snooks, river snooks, and a variety of others. They are caught with hook and line, in cast and seine nets, in traps, and by spearing or harpooning. Fish traps are cylindrical in shape, with a funnel-shaped opening at each end, the apex of the funnel pointing toward the center of the trap, so that entrance is easy but exit very diflicult. The traps, made of split bamboo, are placed upon the bottoms of rivers or lagroms, baited with "masa," which attracts multitudes of the tiny fish there abounding; these in their turn attract larger fish, which cnter the trap in pursuit of the small fry and are captured. Harpooning at night by the light of a split-pine torch bis about the nearest uppronch to real sport which the Indian enjoys; this is usunlly done near the bar of a river, on a calm dark night, by three men in a canoc, one paddling, one holding the toreh, and the third wieldingr the harpoon. This implement eonsists of a slendere eme 10 to 12 foet in longth provided with a sharp barbed spindle-shaped stod head, fitting into the hollow at one end, so that on striking the fish the houd parts from the shenft to which it is attuched by a cord held in the hand of the harpooner. The fish are attrated by the liegh of the toreh, and the harpooner strikes at the swirl which they make 
alongside the dory. IIarpooning is rather an exciting form of sport, as it is impossible to tell what sort of fish has been struck until it is landed. Hicatee and bucatora are harpooned with an unbarbed triangular point, this giving the best hold on their tough shells; they are captured also by spreading small nets in the vicinity of the stumps and holes along the river banks, which they frequent.

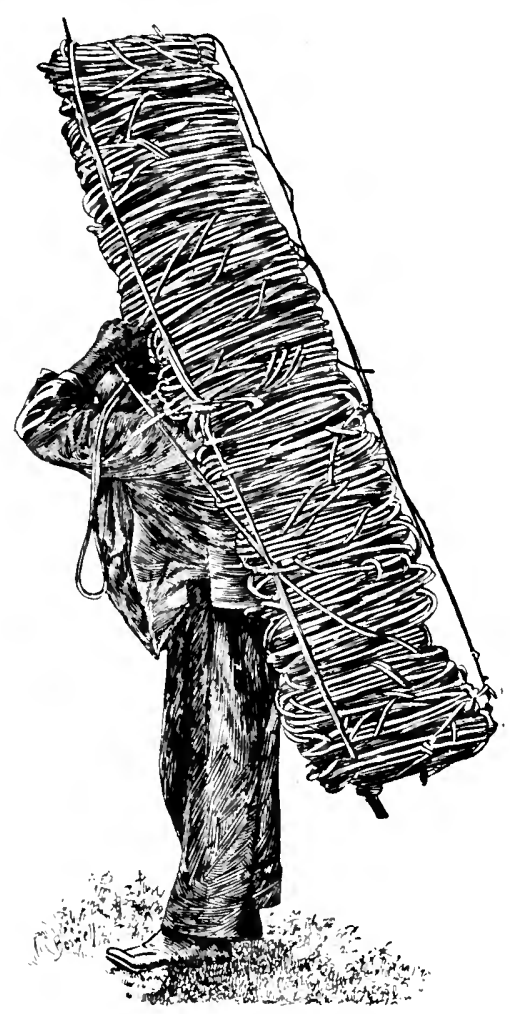

Fig. 7.-Indian carrying load of hejuco, a liana used as rope in houes building.

\section{CONSTRUCTION OF HOUSES AND} FURNITURE

The Indians construct their houses in the following manner: First a number of straight trees about 8 inches in diameter at the base and crotehed at the top are seleeted in the bush for posts. These are usually Santa Maria, chichem, sapodilla, or some hardwood. They are cut down, and after having been peeled are dragged to the site of the new house, where they are firmly planted, one at each of the four corners and others, the number depending on the size of the house, at short intervals between in the lines of the walls. In the crotehes other slightly smaller poles 5 to 6 inches in diameter, also peeled, are laid; to these are attached still smaller poles, which run up to the ridgepole (honache), forming rafters (uinciche). All this framework is firmly bound together by means of ropes of liana (fig. 7). Rows of long thin pliable sticks are next bound round the rafter's, and to these are attached layer upon layer of "huana" (shaan) leaves till a thatch, sometimes 18 inches thick and quite impervious to rain, is formed (pl. 4).

The walls between the posts are filled in with "tasistas," a small palm trunk, or in some cases with strips of split cabbage palm. The outer sides of the walls may be daubed with a mixture of mud and hair, or of chopped fiber (pakloom), and whitewashed, or they may be thatched with palm leaves. The floor is made of marl dust pounded down to a flat hard surface.

Doors and windows may be made of wickerwork of liana, of split eablage palm, or of a frame of sticks thatched with palm leares. When a man undertakes the building of a new house his neighbors 


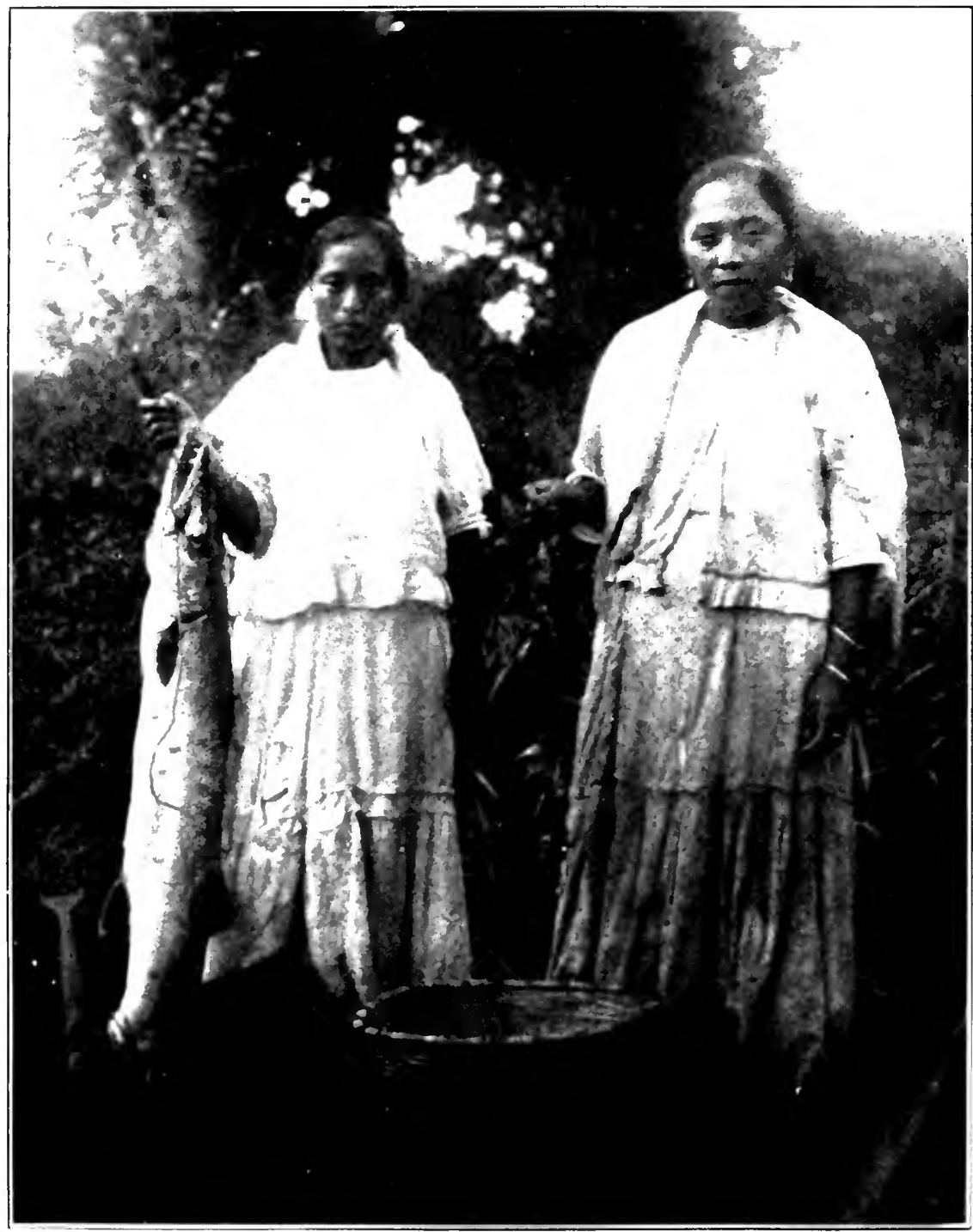

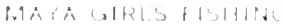




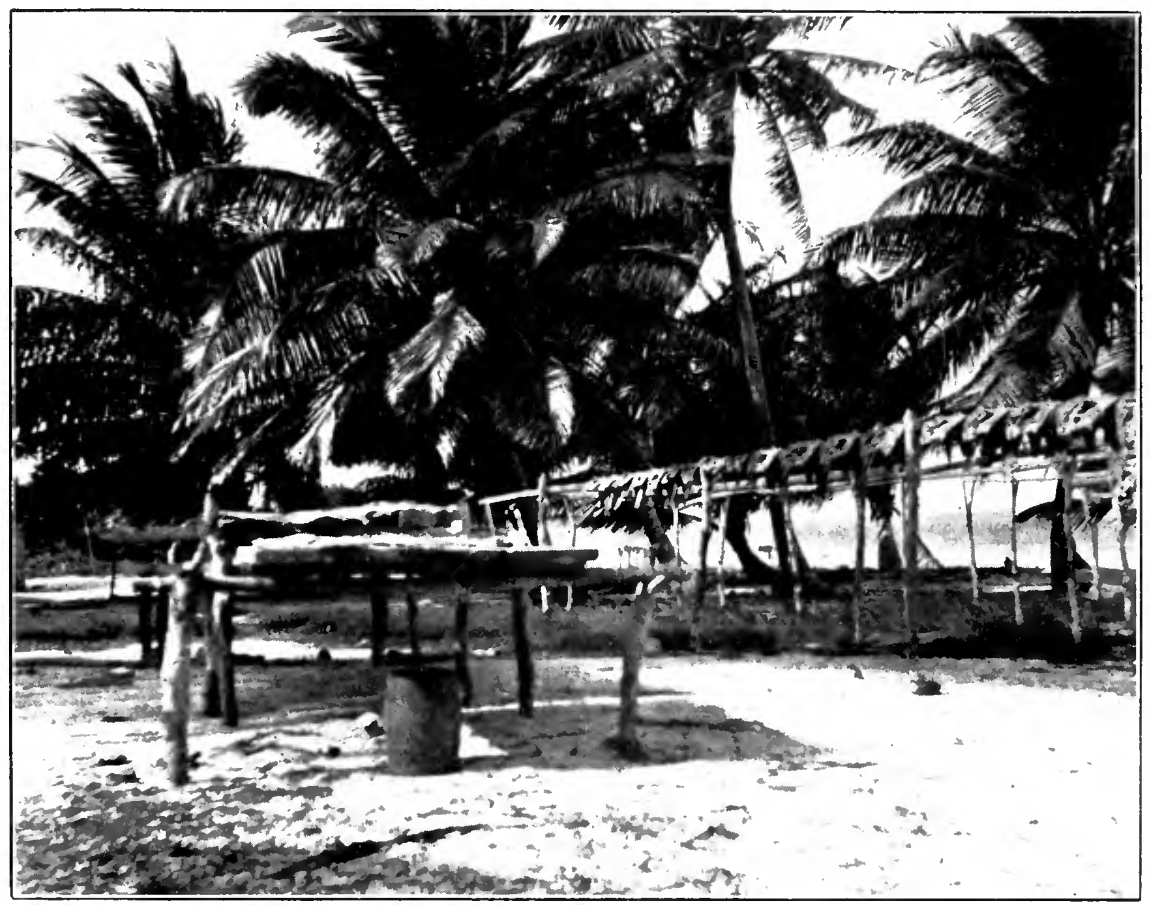

FISH DRYING ON ONE OF THE CAYS OFF THE COAST OF YUCATAN 

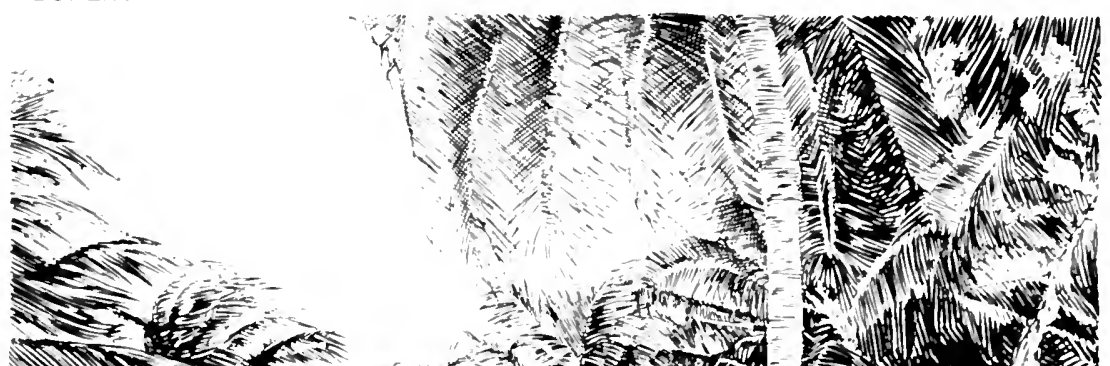
-

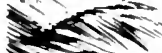

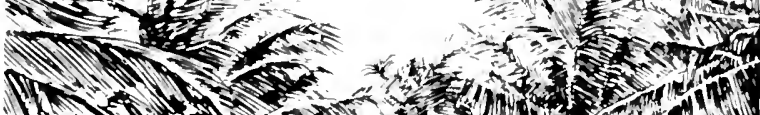

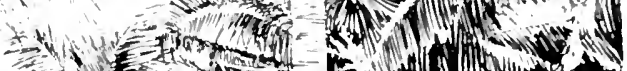
L. 1 .

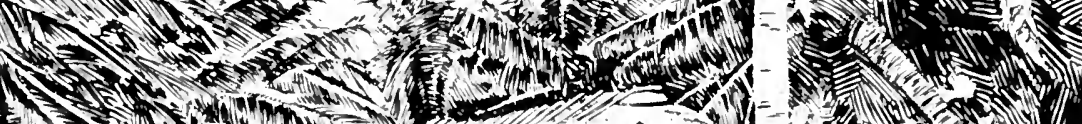

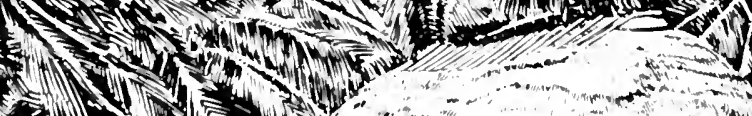

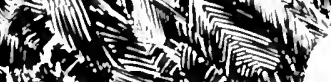

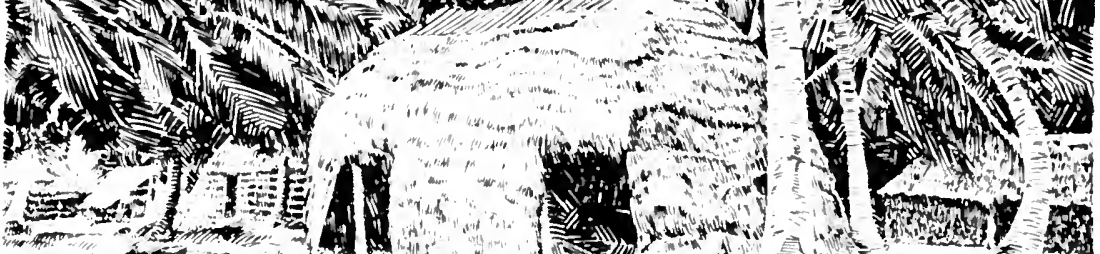

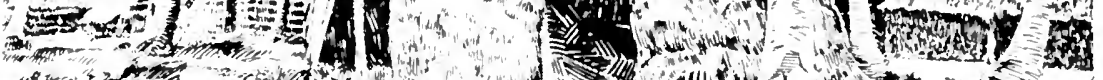

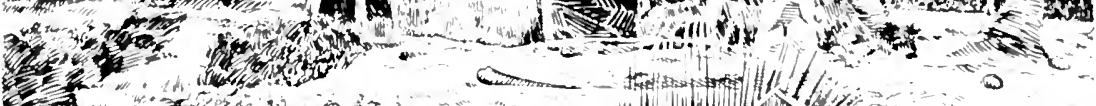
(1)

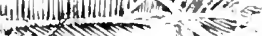

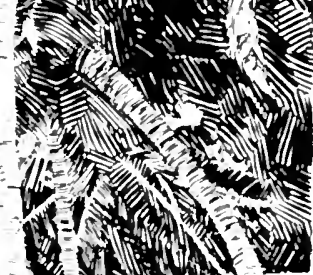

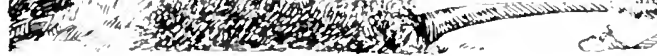

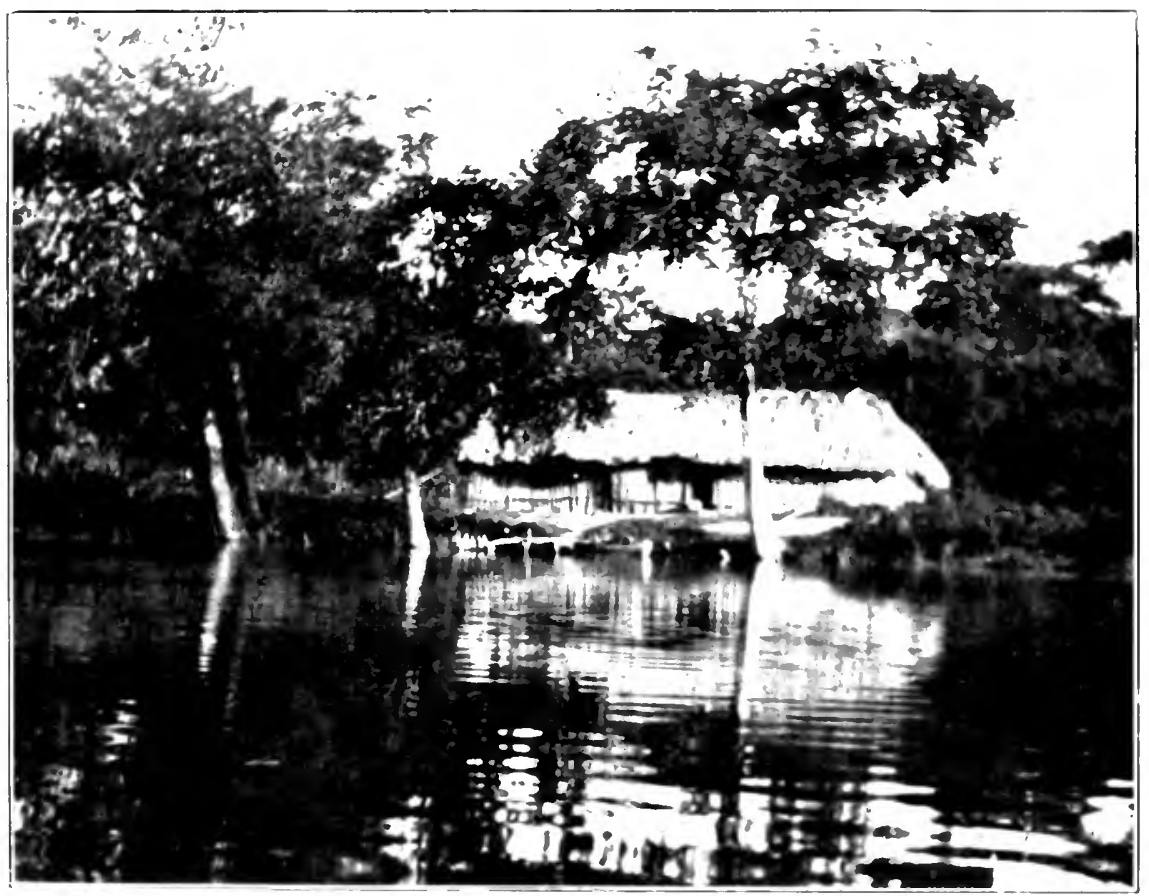



usually help him, and the residence is ready for occupancy in a few days, as all the materials are growing ready to hand in the neighboring forest, and require only cutting down and assembling. The facility with which their dwellings are constructed, and the difficulty in getting more than one or two crops in succession from each plantation, with their primitive agricultural methods, probably account for the frequent changes in site which one notices in Indian villages. As the lands in one neighborhood become impoverished, the population has a tendency gradually to desert the old village, and start a new one in a more favorable locality.

The kitchen, which is a replica of the house on a small scale, is usually placed a few yards behind it.

The furniture is of the simplest, consisting of a small round cedar table, with a little bowl-shaped projection which contains a lump of masa when tortillas are being made and chili peppers or salt at meal times. The seats are mere blocks of wood, 3 or 4 inches high (caanche), with perhaps one or two more pretentious low hollow-backed wooden chairs covered with deer skin or "tiger" skin. A number of calabashes of all shapes and sizes, with a few earthen water jars, iron cooking pots, and placues for baking tortillas, are found in all houses:

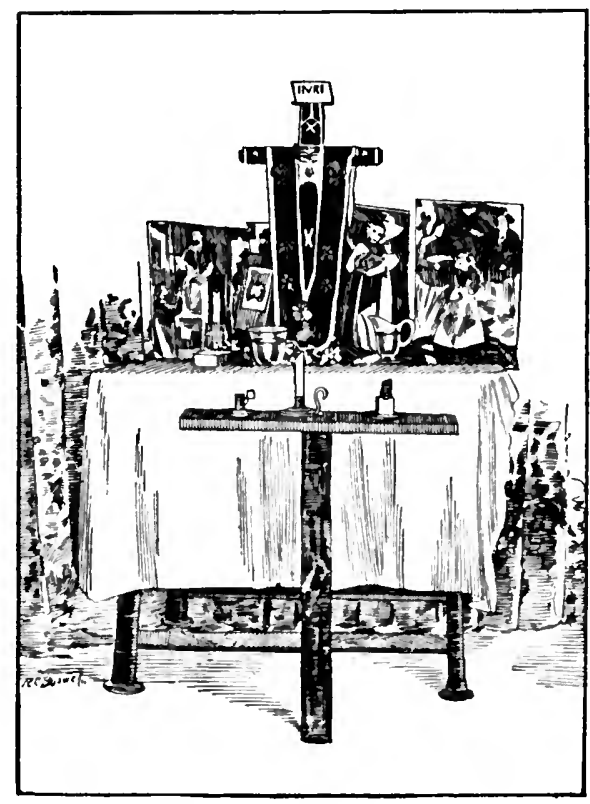

Fig. S.-Domestic altar.

Inammocks (láan) of cotton or benequen fiber are always conspicuous urticles of furniture, as they are slung all around the room, making it very diflicult to move about in it when they are let down. In many houses contact with the hammocks is not desirable, as lice have a habit of lenving the borly of the hammock during the day and secreting themselves in the knots between the berly and the alms, whenee they may transfer themselves to the gatments of the unwary. If the hammock is latree the father and mother often stere in one, their heads at opposite ends, white the smatler rhildren, frecuently to the mumber of theere or forre, ocenpy another. There can be no such thing as privary, as the whole family commonly scepe live, and ant in a single room, which at most is divided inte two apartments by a flimsy cotton curtain. A prominent 
object in most Indian houses is an altar (canche), or high square table, upon which stands a wooden cross (fig. 8). The altar is covered with a cotton cloth, embroidered in flowers and religious symbols; the cross is draped with ribbon or strips of colored fabric, and sometimes with crude models, in silver or gold, of legs, arms, and hands, representing thank offerings to some favorite Santo for the healing of corresponding parts of the body. Little images in wax, and, if the Indian can obtain them, religious oleographs and medallions, with colored-glass vases, are commonly found upon the altar, which is frequently dressed with fresh flowers.

The Indian's only tool is his machete, a heavy cutlass-like knife, about 16 inches long; with this he cuts and cleans his milpa, makes his house and most of his furniture, digs postholes, and fights and defends himself.

His indispensable belongings consist of a hammock, a few calabashes and pots, a machete, and a cotton suit, all of which he can carry slung over his back in a macapal; with his wife and dogs trotting behind him, he can leave his old home and seek pastures new with a light heart and untroubled mind, knowing that the bush will provide for all his needs.

POTTERY MAKING

Pottery making is rapidly dying out through the greater part of this area, owing to the importation of more convenient and durable vessels. It is undertaken almost exclusively by the older women, who employ a fine light yellow clay mixed with sand or powdered quartz. They make vessels in considerable variety, both as to size and shape, which are used for the storage of water and dry material, as corn, beans, and achiote, and as cooking pots. They do not use a potter's wheel, but mold the smaller utensils by hand and buikl up the larger by the addition of fragment upon fragment of cliy. The outside is smoothed over with a little wooden spadelike implement. No polish, glaze, or paint is applied to the pottery, either inside or out; the highest effort at decoration resulting in merely a few incised lines just below the neck, or a rough sealloping around the rim. 'The pottery is burned in a clear, open wood fire; when completed the ware is known as $u l$.

\section{BOAT BUILDING}

The Indians living in the neighborhood of lakes and rivers possess dorices or canoes which rary in size from tiny craft 5 to 6 feet long by 16 to 18 inches beam, capable of holding only a single individual, to large craft 25 feet or more in length, large enough to hold a dozen people. All their canoes are constructed by the simple process of hollowing out linge logs, the more durable ones being male from cedar, the lighter ones from wild cotton (yaxche). The boats are 


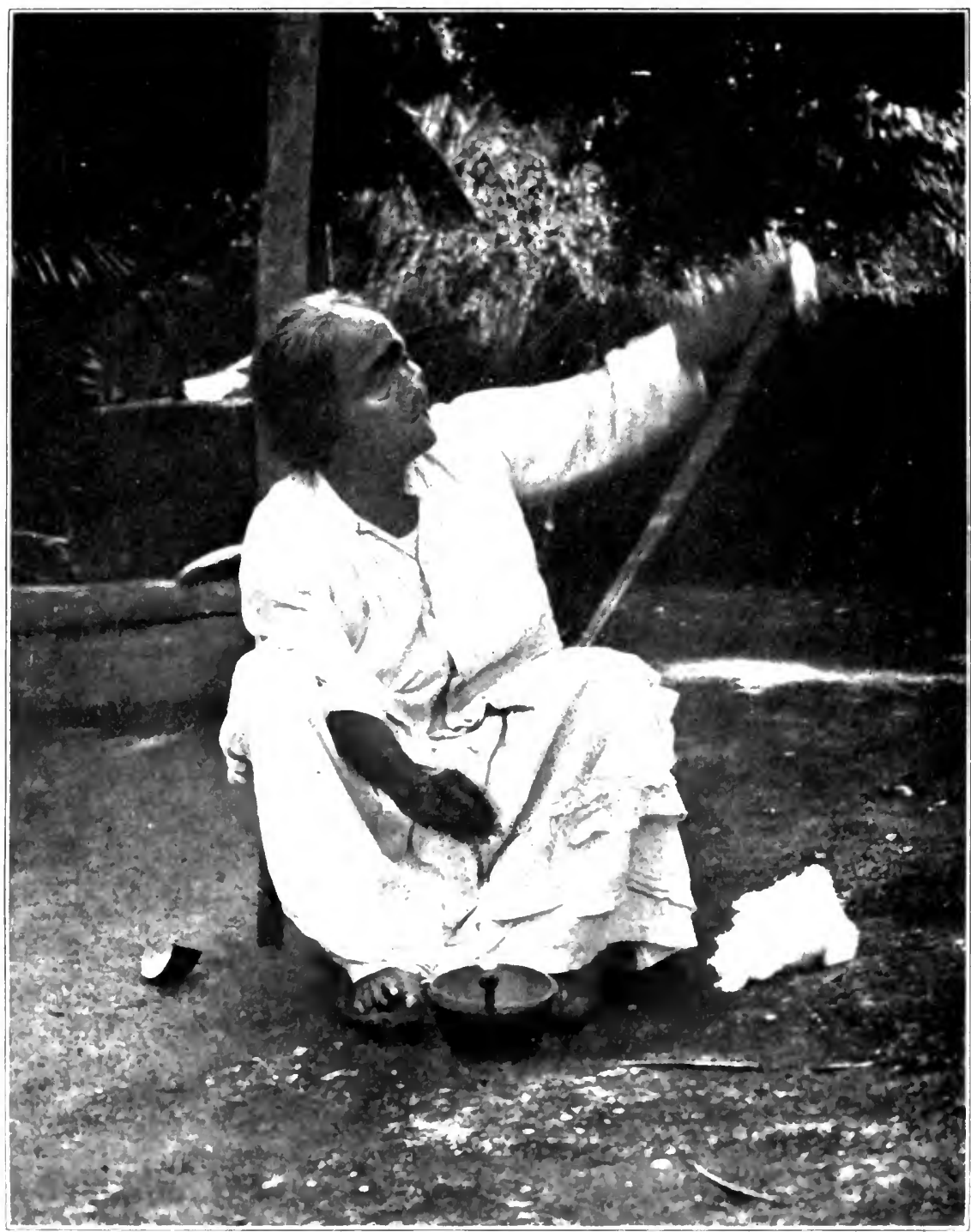




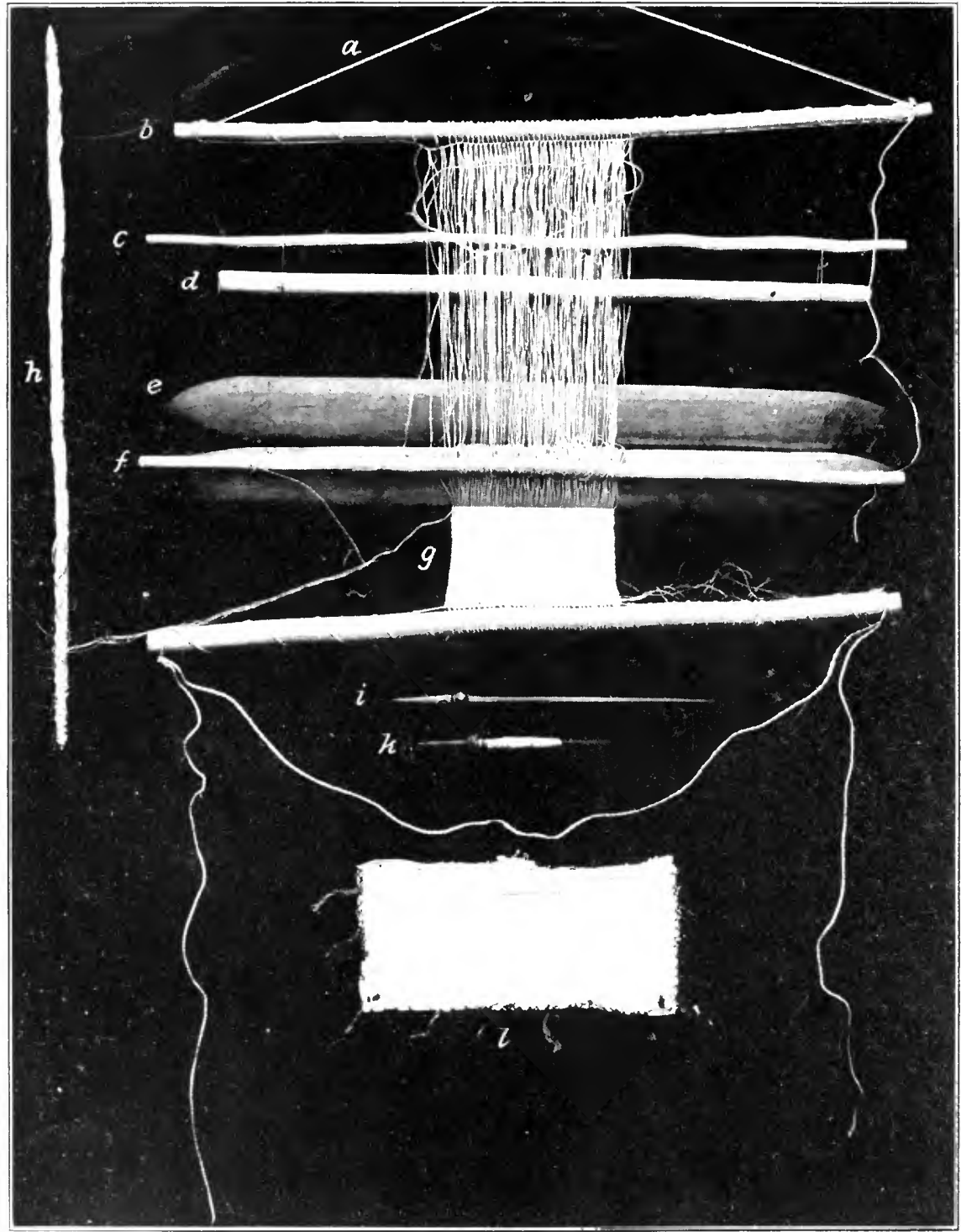

MAYA LOOM

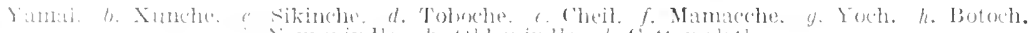

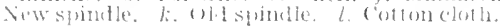


pointed, bow and stern, and when steel tools are arailable to their makers the lines are often very graceful. Many of the boats, however, follow to some extent the contours of the logs from which they were made, being exceedingly clumsy and difficult to manage. On the rivers and lakes the only methor of propulsion is by means of a broad-bladed cedar paddle about 5 feet long, or, where the water is shallow and the bottom hard, a long pole. Both men and women have acquired considerable dexterity in paddling and can keep it up at a 4-mile-an-hour gait from early morning till late at night, with very short intervals for refreshment. They use their canoes for trading corn, vegetables, lime, and live stock among villages along the river banks, for line fishing, spearing, and netting, and for getting from place to place. On the large lagoons and along the seacoast they sometimes use the pole to support a lug sail.

\section{SPINNING ANI) WEAVING}

Spimning (kuch) is done by means of a spindle (hechech) of hardwood, 12 to 14 inches long, weighted about 3 inches from the bottom with a hardwood or pottery ring (pl. 5). The upper end is revolved by the finger and thumb of the right hand, which are constantly rubbed on a picce of stonelike substunce, made from decrskin burned and ground to a powder, to prevent them from sticking (fig. 9). The cotton (toman) may be held in the left

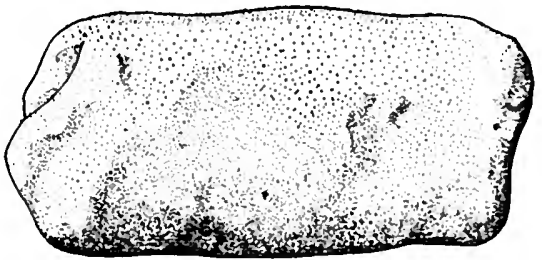

Fig. 9. - Stonelike sulistance nised to prevent fingers from sticking while spinning. hand, or on the shoulder; the lower end of the spindle rests in a small calabash (luch), which is cemented into a support of woven liana (met), the luch and met together being known as toh (fier. 10).

Weaving is done on a simple loom consisting of a cloth beam and yarn beam (xunche) of light strong wood, connected by the warp (cheil) (pl. 6). The (roth beam is attached round the back of the weaver by a thick henequen cord (yamal), enabling him to tichten the warp at will by simply loming backward. The yarn beam is usually attached to a doorpost. The shuttle (botosh) consists of a light stiek, pointed at both ends, on which the woft is wound obliquely. All the alternate warp strands may be raised togrether by means of a hedelle (mamacehe consisting of a number of loops at auched to a rod, areh loop passing round a warp strand, so that when the rod is raised the warp threats are raised with it. The lease rods (helehteh) consist of splints of hard heary wood, usually sapodilla, 2 to 3 inches broad, one-third of an inch thick in the conter, with sharp oderes and pointed ends. A loose rod (tebreche) about the size of the yarn beam 
is used to roll up the completed material (yoch). The loom for cotton cloth is usually $2 \frac{1}{2}$ to 3 feet broad, but much smaller looms are frequently used for narrower strips of material

\section{MINOR INDUSTRIES}

\section{Tobacco Curing}

The tobacco leaves are lung in bunches, often under the roof of the com house, in the milpa, in a free current of air, till they are thoroughly dry; they are then powdered in a shallow basin, or the bottom cut from a large calabash, and mixed with the leaves of the chiohle, a species of vanilla, which gives a distinetive flavor and fragrance to the tobaceo; finally the mixture is rolled into cigarettes (chiople) in a covering of corn husk (coloch).

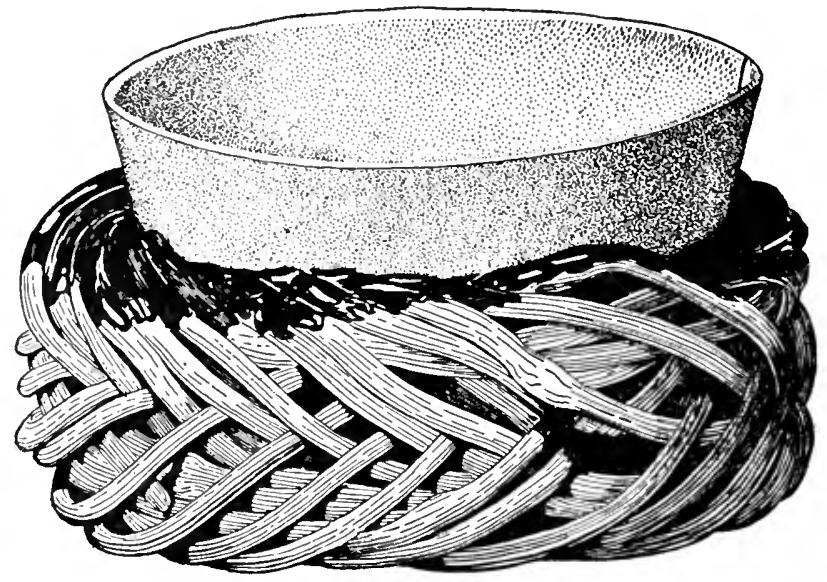

FIG. 10.-Calabash with liana base used in spinning.

Basket and Mat Weaving

Baskets are woven from a special thin tough liana and from split cane; those of liana $(a k)$, which are large and coarse, are ecmmonly used for earrying corn from the milpa, slung over the shoulders like a macapal. The split-cane baskets, which are smaller and more neatly woven, are used in the house for all sorts of domestic purposes.

Henequen fiber is used by the Indians for a great variety of purposes. The fiber is obtained from the leaf, which is cleaned upon a smooth board (pokche) about 4 feet long by 6 inches broad, in the following way: The top of the board is held against the lower part of the operator's chest while the lower end rests on the floor. The leaf is placed on the board and the pulp scraped from the fiber with a bar of hardwood, triangular in section. At the upper end of the board is a deep notch in its side, in which the cleaned part of the leaf is clamped, thus fixing the part which is being scraped. The 
cleaning has to be done very early in the morning, as when the sun gets hot the juice from the pulp produces an unpleasant itching rash upon the skin. The fiber when cleaned and dried is made into rope and cord; from the cord hammocks, sacks, a coarse kind of cloth, and many other articles are manufactured. Candles are made by dipping a wick of twisted cotton in to melted black beeswax (boxkeb), obtained from wild bees. Sometimes a number of the logs in which the wild bees hive are brought in to the village and placed one above the other, on trestles, to form a sort of apiary, in order that honey and wax may be always obtainable.

Oil for cooking and for burning in small earthenware lamps with twisted cotton wicks is obtained by breaking up the kernel of the cuhoon nut and boiling it in water. A clear rather thin oil floats to the surface, which may easily be skimmed off. Near the sea coconut oil is prepared in the same way. 


\section{SOCIAL CHARACTERISTICS}

\section{VillaAges}

The villages vary in size from two or three houses to two hundred or more, with inhabitants numbering from 10 or 12 to more than 1,000 . In the smaller villages the houses are very irregularly disposed; in the larger they are arranged more or less regularly so as to form streets around a large central space, or plaza, where the dance house and church are usually situated. Each house is surrounded by its own patio, or yard, generally inclosed in a fence of "tasistas," in which the bush is allowed to grow to a considerable height in order to provide a convenient latrine for the women and children. Dogs, pigs, and vultures serve as seavengers. Many of the Indians, especially the Santa Cruz, are at great pains to conceal the whereabouts of their villages. Along the main roads only a few scattered groups of huts will be seen, while the larger villages are approached by tracks so inconspicuous that they may easily be missed. The villages themselves are surrounded by a maze of narrow tortuous paths, in which a stranger may wander about for some time before finding his way in. The Santa Cruz are said sometimes to cut the tongues from their cocks in order to prevent them erowing and so betraying the situation of the village.

'The Indians are very jealous of outside interference in their affairs and lo not permit foreigners to reside in their villages. An exception was made in the case of a number of Chinese coolies imported into British Honduras many years ago, most of whom ran away to the Santa Cruz country, where they were well received and married Indian wives. Among their offspring, it is interesting to note, are found a very unusual proportion of defectives. On one oceasion the Mexican Governmeit commenced to cut a road through from Peto to Santa Cruz, the Indian capital. Five of the Santa Cruz Indians went to see the work going on and were well received and given useful presents. On returning to their own country, however, they were executed by the head chief as traitors for encournging the entry of outivilers into their territory.

\section{Marriage and Childoren}

The Indian girls married formerly at about 14 or 15 , the boys at about 17 or 18 years. After the conquest of Bacalar, however, and the expulsion of Yucatecans from Indian territory a law was passed making marriage compulsory for all girls of 12 years of age 
and upward. 'This was probably done with the idea of increasing the population, which had been considerably depleted by the longcontinued war. Formerly, the first question of a girl's father to her suitor was "Ilai tzak a kul hai tzak taman?" (How many macates of corn and cotton have you?); but at the present day there are not enough men to "go round." 'The Indians of British Honduras are usually married by the Catholic priest, though the actual ceremony is often performed months or even years after the young couple have set up housekeeping together, since owing to the remoteness of many of the Indian settlements the priest can visit them only at long intervals. Among the Santa Cruz marriages are not considered legal unless performed by an official known as the yumxcrib (probably derived from the Maya Yum, "lord," and Spanish escribano), who holds a position somewhat anulogous to that of colonial secretary in a British colony.

The babies and smaller children in general are pretty, merry little things. The mothers almost invariably nurse them well into the second year, as the mammary glands are renarkably well developed and the secretion is abundant and long continued. Children are much desired by both parents and are well treated and loved, though not spoiled. If the father and mother separate, the very young children remain with the mother; of the older children, the boys go with the father, the girls with the mother. If small childron are left destitute by the death of both parents, the nearest relative takes them, and in the absence of relatives they are distributed by the subchief among families of his choosing in their own village. When a man dies his widlow takes the home, furniture, domestic animals, corn, and plantations; other possessions, if such exist, are divided equally between the widow and the older children, each taking such articles as will be most useful to him or her. When a woman dies her jewelry, ornaments, and clothes are divided between her daughters. The marriage tic is a somewhat loose one, and the more the Indians come in contact with civilization the looser it secms to become. In British Ilonduras, where the Indians are clescly associated with Spaniards, Mestizos, Negroes, and other races, the women change their partners with the utmost facility. The Negroes are called kisinbosh, "black devils," by the Indians, a term which, however it originated, is now employed without any particularly opprobrious significance, as many of the Mayn women show no repugranere to a Negro husband. A good deal of the immorality is brought about by the cheapness of rom and the facility with which it is obtainable by the Indians. The husband takes to drink, neglects his wifo and fimily, and probubly gets entangled with some other woman: the wife, in order to obtain food, clothing,

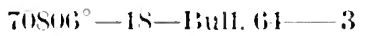


and $a$ shelter for herself and children, is driven to an alliance with some other man who is a better provider. The consequence is that in British Honduras all degrees of racial mixture are to be found between Indian women and European, East Indian, Chinese, and Negro men, who, again intermarrying, produce a bewildering racial kaleidoscope.

The Indians are a short-lived race, a fact due partly to their indigestible and badly cooked food and partly to the prevalence among them of malarial fever (chokuil), with aceompanying anemia (xcan mucui) and splenic enlargement (canchikin), but chiefly to overindulgence in alcohol whenever an opportunity offers. Notable exceptions to this rule are, however, not uncommon, and once an individual passes the four-score mark he or she is quite likely to live to well over 100 years: dried up, wrinkled, and feeble, but clinging to life with an almost incredible tenacity.

\section{DrunkenNess}

Landa frequently mentions the fact that in his day drunkenness (kaltal) was the curse of the Indians and the cause of many crimes among them, including murder, rape, and arson. ${ }^{1}$ It the present time these remarks apply equally well; indeed, drumkenness is probably more prevalent than formerly, as the rum is made locally and is far more intoxicating than the balchè, which Landa describes as a drink made from fermented honey, water, and roots. Moreover, the people drink rum at all times and seasons, whereas both the preparation and consumption of balchè were to some extent ceremonial, as was the resulting intoxication. Drunkenness is not considered in any way a disgrace, but is looked on rather as an amiable weakness. The women, especially the older ones, drink a good deal but they usually do so in the privacy of their own houses. I have seen, however, a little girl of 14 or 15 purchase a pint of rum in a village liquor store, and go out on the plaza, where she drank it in a few gulps; then, lying down in the fieree heat of the afternoon sun, she lapsed into alcoholic coma. Alcohol effects an extraordinarily rapid change for the worse in the Indian's temperament; from a quiet, polite, rather deferential individual, he is converted almost in a moment into a maudlin idiot, staggering about singing foolish snatches of mative songs, and endeavoring to embrace everyone he comes in contact with. When thwarted while in this condition his temper is likely to flare up at the slightest provocation, whereupon the thin rencer of eivilization and restraint is sloughed in a moment, and he becomes savage, impudent, overbearing, and contemptuous,

\footnotetext{
1 Que los indios eran muy dissolutos en bever y emboracharse, de que les seguian muchos males, como. matarse unos a otros, violar las camas. . . y pegar fuego a sus casas.-landa, Relacion de las Cosas de. Yucatan, chap, $\mathrm{x} \times \mathrm{II}, \mathrm{p} .122$.
} 
toward the stranger, and ready to draw his machete and fight to kill, with friend or foe alike.

\section{Chiffs}

On the death of the head chief (noh calan or nohoch yumtat) among the Santa Cruz and Icaichè the oldest of the subchiefs (chan yumtopilob) is supposed to suceced him; as a matter of fact there are always rival claimants for the chieftainship, and the subchief with the strongest personality or grentest popularity among the soldiers usually succeeds in grasping the office. There are nearly always rival factions endeavoring to oust the chief in power, and the latter rarely dies a natural death. The village subchicfs are elected by the people. The power of the head chicf is practically absolute over the whole tribe. Some years ago, when Roman Pec was head chicf, one of the subchiefs came to Corozal, the nearest town in British IIonduras, to purchuse powder, shot, and other supplies. Ife remained some time, as he had many friends in the place, and obtained, among other things, a bottle of laudanum to relieve toothache. On returning to his village he was met by three soldiers, who informed him that he was to go with them at once to the head chief, as the latter was angry with him on account of his long absence from the country. Nware that this was equivilent to a sentence of death, he asked permission to retire to his house for a few minutes, to get ready for the journey, and taking advantage of the opportunity, he swallowed the whole contents of the bettle of laudanum. This began to take effeet very shortly, and long before reaching the capital he was read.

The method of executing those sentenced to death is eurious. The aceused does not undergo a formal trial, but the evilence against him is placed before the head chief; if he is convicted, he has an opportunity of defending himself and of producing witnesses in his behalf. Three or four soldiers are chosen by the chief to carry out the sentence; this they do by chopping the vietim to death with their machetes when they catch him askeep or off his guard. Several men always perform this atet, all ehopping the vietim at the same time, so that no singhe individual may be directly respomsible for his death. Imprisonment as a punishment for arime is unkuown, fine, flogging, and death being the only threes mothods comployed for dealing with criminals. Fines and flogrging may be administered by the subehiefs, but sentence of death can be pasied mly by the heal chicf. The severity of the flogging is renuluted by the nature of the offense, and after it is orer the recipient is compelled publicly to axpress sorrow for his crime and go arouml humbly kissing the hands of all the spectators, after which he is given a larere calabash of anise to drink. 'The heariest pun- 
ishment is inflicted for witcheraft or sorcery, as the pulya, or sorceress, is greatly dreaded by the Indians. She is literally chopped limb from limb; but whereas the bodies of other victims executed in this way are always buried, that of the pulya is left for the dogs and vultures to dispose of.

Military servico is compulsory for all adult males among the Santa Cruz, though many avoid such service by payment to the chief of a certain sum in money or its equivalent. Small garrisons were kept up at Santa Cruz, Chan Santa Cruz, Bacalar, and other Indian towns where soldiers were permanently stationed. No uniform was provided, though many of the men were armed with Winchester rifles. They were provided also with a ration of corn and beans, and often took their wives along with them as cooks.

\section{Diseases and Medicines}

Indian men and women of all ages and classes, when attacked by any serious malady, are found to be lacking in vitality and stamina; they relinquish hope, and relax their grip on life very easily, seeming to hold it lightly and as not worth a fight to retain. An ellerly man or woman will sonietimes take to the hammock without apparent physical symptoms of disease beyond the anemia and splenitis from which nearly all suffer, and merely announce Ile in cimli, "I am going to die." They refuse to eat, drink, or talk, wrap themselves in a sheet from head to foot, and finally do succumb in a very short time apparently from sheer lack of vitality and absence of desire to continue living.

Malaria is without doubt the chief scourge of the Indian's existence. Many of the villages are built in low-lying situations, with mosquitobreeding swamps all round them, while the scrubby bush and rank vegetation are allowed to grow in the yards right up to the houses, furnishing good corer and an excellent lurking place for the insects; moreover, the Indians seldom use mosquito curtains, as they seem to have acquired a sort of immunity to the irritation caused at night by the noise and biting of the pests. Practically all Indians suffer from malaria, which is the main cause of the splenic enlargement and anemia so prevalent among them. In some cases the spleen reaches an cnormous size, nearly filling the abdominal cavity, and deaths from a slight blow or fall, causing rupture of this organ, are by no means uncommon. Malaria is usually treated by means of profuse sweating (hilcabankil), the patient lying wrapped in a cotton sheet in the hammock, with a fire burning beneath and drinking sudorific bush medicine. This in itself is an excellent remedy, but in the midst of the sweat patients frequently plunge into cold water, thus becoming thoroughly chilled, a procedure very apt to bring on pneumonia, to which they are peculiarly subject. 
The splenic enlargement is treated by applying a number of small circular blisters (xacal) containing chichem juice to the skin, over the affected organ, which seem to be remarkably efficacious in reducing the swelling.

In the winter when the nights are cold the Indians often lie out all night in the wet, a practice which frecuently results in pucumonin and death. Hookworms and many other varieties of intestinal parasites are prevalent, owing to the earth-eating habits of the children, the earth being taken usually from the immediate vicinity of the house, where pigs and other domestic animals have their quarters. This disgusting habit no doubt accounts in part for the swollen beilies and earthy color of many of the children.

Smallpox $(k a k)$ invading an Indian village is a terrible scourge, far worse than in a more civilized community of the same size, where partial immunity has been aequired. Sometimes the whole unaffected population depart 'en masse, learing the dead unburied and the stricken lying in their hammocks, with a supply of food and water, to do the best they can for themselves. The Indians employ the same mole of treatment for this disease as for malarial feversweating followed by immersion in cold water, treatment which, it need hardly be said, is not infrequently followed by disastrous results.

Venereal diseases of all kinds are remarkably rure among all the Indian tribes. Among the Santa (ruz and Icaichè such diseases were practically unknown. Even among the mixed breeds of British I Fonduras they are comparatively rare, notwithstanding the fact that these natives have come much in contact with people of many other races, cspecially of late years with Mexican Chicleros, nearly all of whom are affected with rencreal disease in one form or another.

simple fractures of the long bones are set very neatly and skillfully in the following way: The fractured limb is pulled away from the body with considerable force in order to overcome the displacement; over the fractured bone is wound a thick layer of cotton wool, and orer this are applied a number of small round, straight sticks, completely surrounding the limb, their centers corresponding nearly to the scat of fracture; these are kept in place by a firm binding of henequen cord. The limb, if an arm, is supported in a sling; if a lew, the patient is confined to his hammock till the fracture is firmly knit. Excellent results are secured by this method, the minion being firm, and the limb nearly always uniting in grood position.

Btoedingr, a farorite remedy for all complaints, is esperially resorted to in cascs of headache and malarial ferer. Lsually the temporal vein. lasis frecplently one of the veins in the front of the forearm, is opened. having been first distended with hlood by tying a ligature around the eppere arm. A chip of obsidian, a sharp splinter of bone. or a

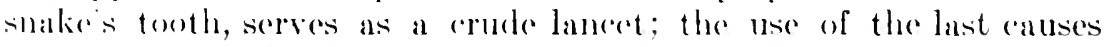


considerable pain, but is believed to have some esoteric virtue connected with it.

Decoctions made from the charred carcasses of animals at one time were much employed, certain animals being regarded as specifics for certain diseases. Thus, during an epidemic of whooping cough (xinki sen) a decoction from the charred remains of the cane rat was almost exclusively given to the children to relieve the cough, though in this case it is difficult to trace the connection between the remedy and the disease.

Many eye troubles are treated by placing a small rough seed beneath the lower lid of the affected eye, where it remains for a day; when the seed is withdrawn it is covered with mucus, to which the doctor points as the injurious matter, the cause of all the trouble, which he has removed.

Massage is practiced chiefly for uterine and ovarian pains by the older women, who also act as midwives; it is used also in conjunction with kneading and manual manipulation in the cure of neuralgic pains, strains, stiffness, and rheumatism.

In confinements, which usually take place either in the hammock or on the floor, the dorsal position is invariably assumed. In such cases also massage over the uterus is performed by the midwife. If the desired results are not secured, the patient is made to vomit by thrusting a long coil of hair down her throat, while a woman of exceptional lung power is sent for to blow into her mouth, with the object of hastening delivery.

The Indians use for medicinal purposes a great variety of plants which grow in their country; some of these are purely empirical remedies; others produce definite physiological results and are frequently used with good effect, while a few, apparently on the assumption that "similia similibus curantur," are employed because of some fancied resemblance in form to the diseased part, as $x h u d u b$ pek, twin seeds of the size of small eggs, the milky juice of which is used as an external application for enlarged glands and for various forms of orchitis.

The following plants are used medicinally by the Indians as remedies for the diseases named, respectively:

Aitz.-The milky juice of a tree, used als an application for chronic sores and ulcers.

Acum.- The leaves of this plant are applied hot to reduce the swelling and relieve the pain in enlargement of the spleen and liver.

Purgarion Xiu.-An infusion male from the leaves is anministered warm in blakler and urethinal troubles.

Pakaal.- In infusion made from the leaves of the orange tree is given as a sudorific.

Picki-A paste marle from the leaves of the guava is applied to "bay sore." a specific ulcer somewhat resembling "oriental sore."

Pomolike. A mouth wash marle irom the milk of this tree is used in cases of stomatitis ancl ulceration of the mouth. 
Quimbombo.-The wild okra is greatly esteemed as an external application in cases of snake lite.

Sisim.-An infusion made from the leaves is used as a sudorific in cases of malarial fever.

Sirilpuz.-A yellowish fruit sometimes used as a purgative.

Cabalpixoy. - The fruit of this tree is given in cases of diarrhea, and an infusion made from the hark is used in diarrhea and dysentery.

Claurliosa $X i u .-A_{n}$ infusion malle from the whole 1 ush is greatly esteemed as a bath and lotion in all uterine and ovarian. complaints.

Challhe.-The spinous leaf of this plant is used as a local application to relieve neuralgic pains, and an infusion made from the leaves is given for rheumatism.

Chamico.-An infusion made from the leaves of the convolvulus mixed with other leaves is given to relieve asthma and lyonchial catarrh.

Chaac.-The arrowroot, eaten raw, is regarded as a useful remedy in all 1.ladder and urethral complaints.

Cusuc.-The wood, ground into a paste, is applied to the heats of small children suffering from fever and convulsions.

Ruda.-The leaves of this plant are universally used as an external application for children suffering from convulsions, and frequently in the same inanner for the relief of almost any nervous complaint in arlults.

lict pica.- I sort of cowhage which, mixed with atol or some corn beverage, is largely used as a vermifuge for children.

\section{Gumes}

Both children and adults play many games, most of which have probably been introduced since the conquest. A favorite among thowe is a game known as tak in kul, in which a number of players stand in a row with their hands behind their backs while one, who holds a small pottery disk in his hand, stands behind the row another standing in front. The one holding the disk places it in the hands of one of those in the line, who in turn passes it to his neighbor, so that it travels rapidly up and down the line. The player in front has to gruess in whese hand the disk is at the moment of guessing. If he is right, the holder of the disk hats to come in front while the one who gruesised correctly joins the line.

Chac is a sort of "knucklebones," played with pottery disks, which are tossed from the palm to the back of the hand and back again: the one who drops fewest disks in a given number of double throws wins the grature.

The boys make little bows (pohoche) and arrows (hul) tipped with black wax, with which they play war and honting games.

1 sersaw made from a small tree balaned on a stump is popular, as is also a sort of merry-rotround construeted from a cross of poles fixed on top of a stmomp hy means of a wooden pin, which rotates freely. The ehildere sit at the cxtreme onds of the poles and make the contrivanere rotate by kicking anamst the groumd vigorously at intervals as they gro around. 
The bull roarer, made from a dry seed pod, is popular in some villages and is probably one of the few toys used by the natives before the conquest.

Cricket, baseball, marbles, kites, and spinning tops have been introduced among the Indians of British Honduras, and all have their devotees.

\section{ReLigion}

The Indians, who are extremely superstitious, believe that the air is full of pishan, or souls of the dead. They imagine that these souls are at liberty at all times to return to earth, and that at certain seasons they are compelled to do so. They are regarded as being capable of enjoying the spirit, though not the substance, of food or drink provided for them. Some of these pishan the Indians believe to be friendly and some inimical to mortals. They believe also in spirits, usually mischievous or harmful, known as xtabai, who often take the form of beautiful women, though they have never been human. The natives will whisper a message into the ear of a corpse with the certainty of having it conveyed to a friend or relative in the next world. They firmly believe that the clay images of the gods upon incense burners, at one time found in considerable numbers in forests which had been uncut since the days of their ancestors, live, walk about, and dance at certain seasons. Another belief held by the Indians is that the images of Christian saints are endowed at times with life and perform acts desired by their devotees. A celebrated wooden image, supposed to represent San Bernardo, was credited with considerable powers in this respect, and when an Indian wanted rain for his milpa, the return of an errant wife, or any similar blessing, he would come and pray to the image to obtain it for him. On one occasion an Indian came asking the saint to aid him in the recovery of pigs which he had lost, and on returning to his village found that the pigs had arrived home before him. Next day he returned with the intention of making an offering to the saint, and incidentally to the owner of the house where the image was kept. He found the poor Santo with torn clothes and many burs sticking all over him. On inquiring how this happened he was informed that the saint had been out in the bush hunting for pigs, a quest which had given him a great deal of trouble before he could find and drive them home, and that when he got back he was tired out, his clothes torn by thorns, and covered with burs-an explanation with which the Indian was perfectly satisfied.

The men are very unwilling to dig either in ancient mounds or ruins, as they are afraid of being haunted by the pishan of those whose remains they may disturb; and nothing will induce them to 
go into caves or burial chambers in mounds. Many curious superstitions hang about the ruins found throughout the country. I was assured by an Indian at Benque Viejo that he had gone on one oceasion to the ruins situated near the village, and seeing a pigeon seated on a tree, ruised his gun to shoot it; before he could do so, however, the pigeon turned into a cock, and this almost immediately into an ongle, which flew at him, driving him away. There is another superstition about these ruins to the effect that when the first settlers camo to Benque Viejo they wished to build the village near the ruins, where the land is very good for growing corn, but wero repeatedly driven off by a littlo old man with a long gray beard. At last, giving up the idea, they contented themselves with the present site for the village.

For many years, between the expulsion of the Yucatecans from Bacalar by the Indians and the conquest of the latter by the Mexican troops, some 12 years ago, no Catholic priests were permitted to visit the Santa Cruz country. The Inclians, however, appointed priests from among themselves, who curried out, so far as can be ascertained from those of their number who left the territory and settled in British Honduras, a sort of travesty of the rites of the Roman Catholic Church frecly interspersed with many of those of their ancient religion, which had survived. The headquarters of this religious cult was the capital, where it centered around what was known as the "Santa Cruz," a plain wooden cross, 2 to 3 feet high, which had probably been removed from some church after the expulsion of the Spaniards. This cross was supposed to be gifted with the power of speech (at belicf arising no doubt from the exereise of ventriloquial power's $b y$ one of the priests), and acted as a sort of oracle, to whom all matter's of importance - civil, military, and religious-were submitted for decision. It need hardly be said that the cross never failed to return an answer to all these questions, in entire conformity with the wishes of the chief. ${ }^{1}$

\footnotetext{
In 1859 a mission was dispatched )y the superintendent of British II onduras to the chiefs of the Sunta Cruz, with the object of reseung spanish prisoners held by them. The following account is from ". I narrative of a journey across the unexplored portion of British llonduras, with a sketch of the history and resources of the colony," by llonry" Fowler, colonial secretary (130lice, 14:9):

"That night as usmal all the avilalile luelins in Bas:al ar urrived in front of the home where the santa Cruz is kept. The boy attentants or sent ries on the idol, called ancels, wore in front of it and the drums and bugles sounderl at recurring parts of the song. The chinf was inside with the image and the angels. The subordinate chiefs and soldies knelt ontside, and dith not rine unt il the service was over, when they

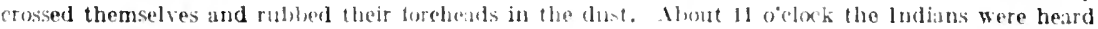
running backward and forward, and an oreter was gri en we bring out the priconers, who were placed in a

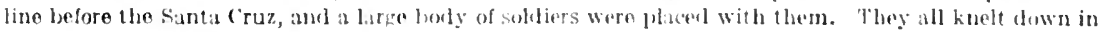
the road. 'There were about 10 female prisoners, with one aren tied to the side, and 12 or 14 men pinioned

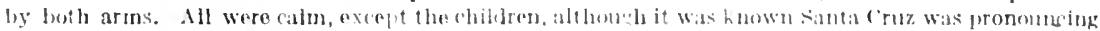

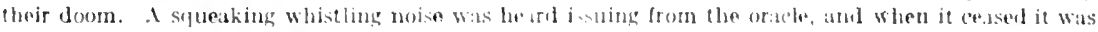

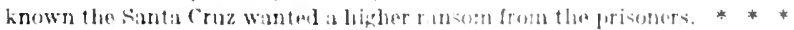

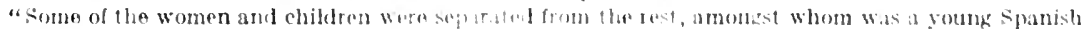
garl well known in high circles. A prowe

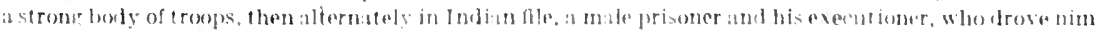
on with his machete, holling him ly a rope; new came the women, 35 in number, driven and held in a
} 
The Indians here under consideration oceupy an intermediate position between the civilized Maya of northern Yueatan, who have lost nearly all tradition and traces of their former civilization, and the Lacandones of the Usumasintla Valley, who have probably changed but little in their customs and religious observances since the conquest. Nominally they are Christians, but the longer one lives among them, and the better one gets to know them, the more he realizes that their Christianity is to a great extent merely a thin veneer, and that fundamentally their religious coneeptions and even their ritual and ceremonies are survivals-degenerate, much changed, and with most of their significance lost-but still survivals of those of their ancestors of pre-Columbian days. To Christianity, not as a separate religion, but as a graft on that which they already practieed, they seem to have taken kindly from the first; and at the present day, as will be seen, the sun god, the rain god; St. Laurence, and Santa Clara may all be invoked in the same prayer, while the Cross is substituted in most of the ceremonies for the images of the old gods, though many of the latter are called on by name. The four principal religious ceremonies of the Indians are, as might be supposed, closely associated with agriculture, espccially with the corn crop. The first of these ceremonies takes place at the cutting of the bush in which the corn plantation is to be made, the second at the planting of the corn, the third during its ripening, and the fourth at harvest time. Of these the third, known as the Cha cliac, which takes place during the ripening of the corn, and whose object is to secure sufficient rain for that purpose, is by far the most important, and it alone will be described, as it embraces the offerings and ritual of all the other ceremonies.

The day previous to the ceremony the men of the family prepared the pib, an oblong hole in the ground, in which the various corn offerings were to be baked, while during the night the women were busy grinding corn to make masa (a thick paste of ground maize) and pumpkin seeds to make sikil. Very early in the morning of the day of the ecremony the priest with his assistant arriced at the house of the giver. This priest called himself men, but was called by the owner a chac, while the Chichanha priest called himself an ah kin. The Indians chose a site in the midst of a grove of large trees. After clearing away the undergrowth they swept clean a circular spare about 25 feet in diameter. In this they proceeded

similar manner; then another hody of soldiers closed the rear; the Englishmen were not allowed to follow. The procession halted under a clump of trees about 150 yards off. And soon the butchery commenced; shrieks wero hearl, but in 10 mimutes all was over.

"The santa (ruz was mixed up) with some (atholic rites, but retains the leading characteristics of the god who was best propitiated by placing bleeding human hearts within his lips."

In 1 siz the Icaiche were beaten by the santa ('ruz, and, says the chronicler: "The account of the slaugliter and human sacrifice made on that occasion is appalling." 
to erect two rude huts, one 12 feet the other 6 feet square; both were thatched with huano leaf, and the floor of the smaller hut was covered with wild plantain leaves. In the center of the larger hut was erected a rough altar 6 by 4 feet and 4 feet 6 inches high, built of sticks bound together with bejuco (fig. 11). The central part of this

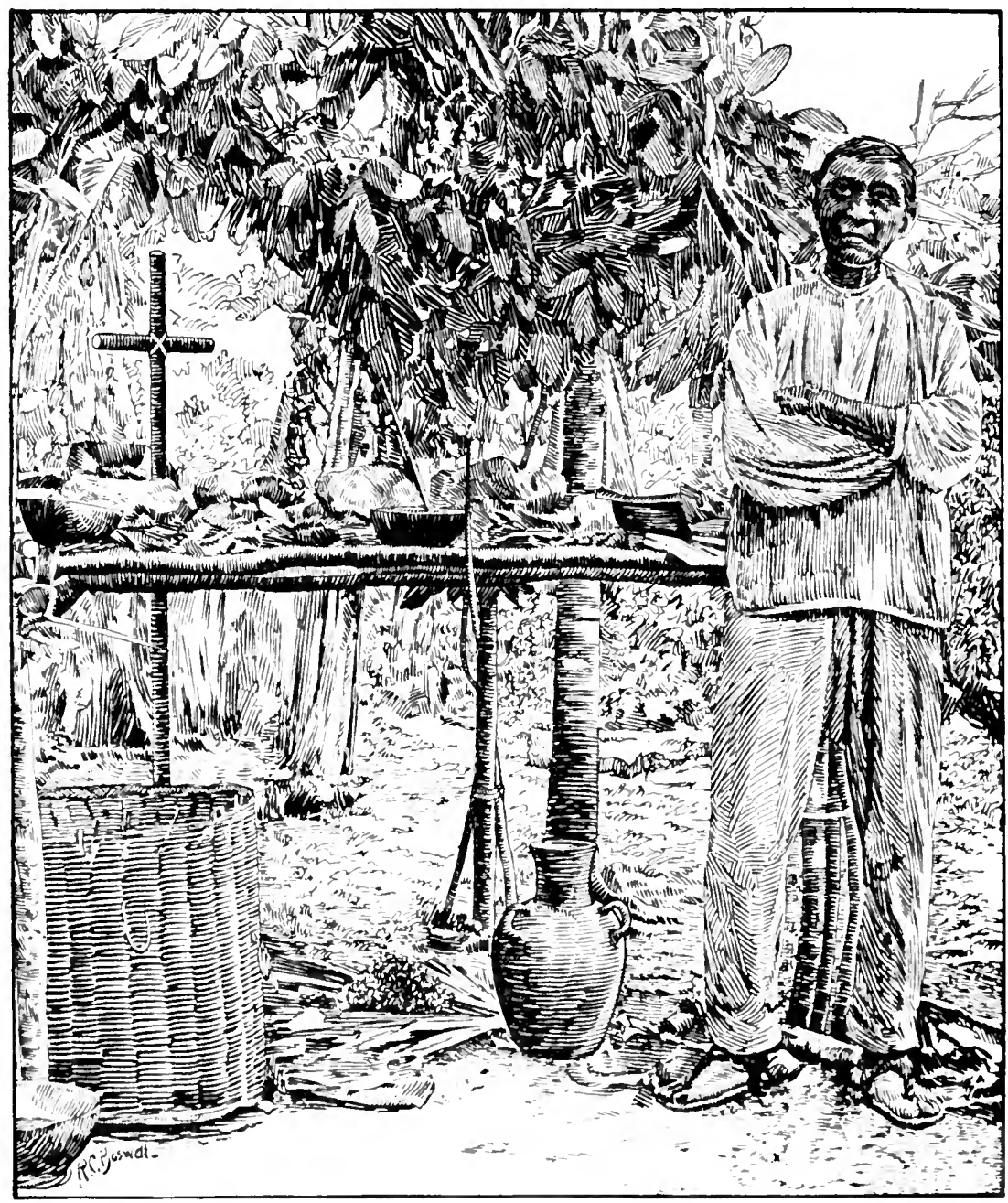

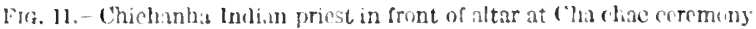

altur was covered by an areh of "jabin" branches with the hases still attached. About a dezen small calab)ashes in their ringropperts (Matyat cheyub) were plated on the altar, and three mose were hung to a string pasing from the side of the shed to a post an few rard away. The masil prepared the previous night wis then brought out in four large calabashes, two of these being placed under the altar 
and two on top of it; a large calabash of sikil and one of water were also placed on the altar and a jar of balchè (a drink made of fermented honey in which is soaked the bark of a tree) beneath it. Bencath the suspended calabashes was placed a small table containing piles of tortillas and calabashes of masa and water. In carrying out this ceremony it is essential that everything used in it be perfectly fresh and new; the leares, sticks, bejuco, and jabin must be freshly cut, and the masa, sikil, balchè, and even the calabashes must be freshly made. The masa was taken from the large to the small shed, where

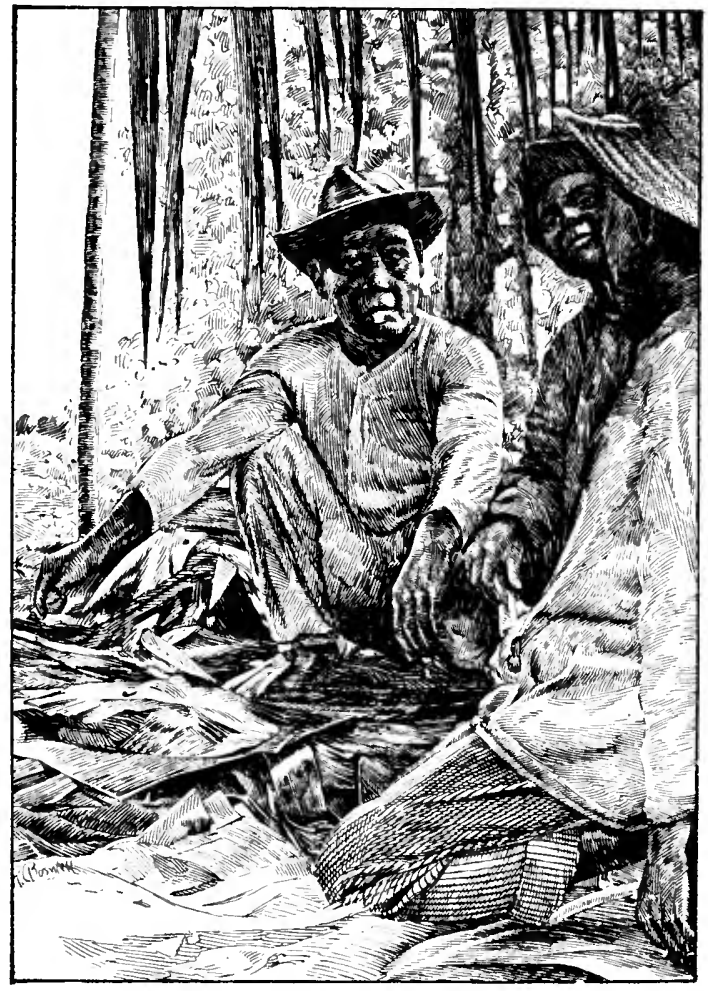

Fig. 12.-Pricst tracing cross on cake and filling it in with sikil. the priest and several male members of the family sat around it. After flattening out a small ball of the masa the priest placed it on a square of plantain leaves and poured over it a little sitil (a thin paste made of ground pumpkin seed and water). Then the next man flattened out a piece of masa, which he placed over the sikit, and the process was continued until a cake was formed containing 5 to 13 alternating layers of masa and sikit. On top of each calke, as it was completed, the priest traced with his forefinger a cross surrounded with boles; these were first partly filled with balchè, which was allowed to soak into the cake, after which they were filled completely with sikil, whereupon the whole cake was carcfully tied up in plantain leaf, with an outer corering of palm leaf (fig. 12). These cakes are known as tutiua; their number is gencrally gauged by the number of participants in the cermony. When sikil is not arailable, a paste of ground black beans is used; in this case the cakes are known as buliua (Maya bul, "bean"; uu, "bread"). The priest next male a deep depression in a ball of masa about the size of a tennis ball, which he filled with sikit, covering it with the masa, so as to leave a ball of 
masa with a core of sikit. A number of these balls, known as yokua, were made, each wrapped in plantain leares. When finished, all of them were wrapped in a large palm leaf and tied into a bundle with split palm-leaf strunds. Two more tutiua were next made, and lastly all the masa and sikil left were mixed together with a few ounces of salt. After being well kneaded this mass was divided into two portions, each of which was tied up in plantain and palm leaf covering.s. In the meantime some members of the family had filled the pib or

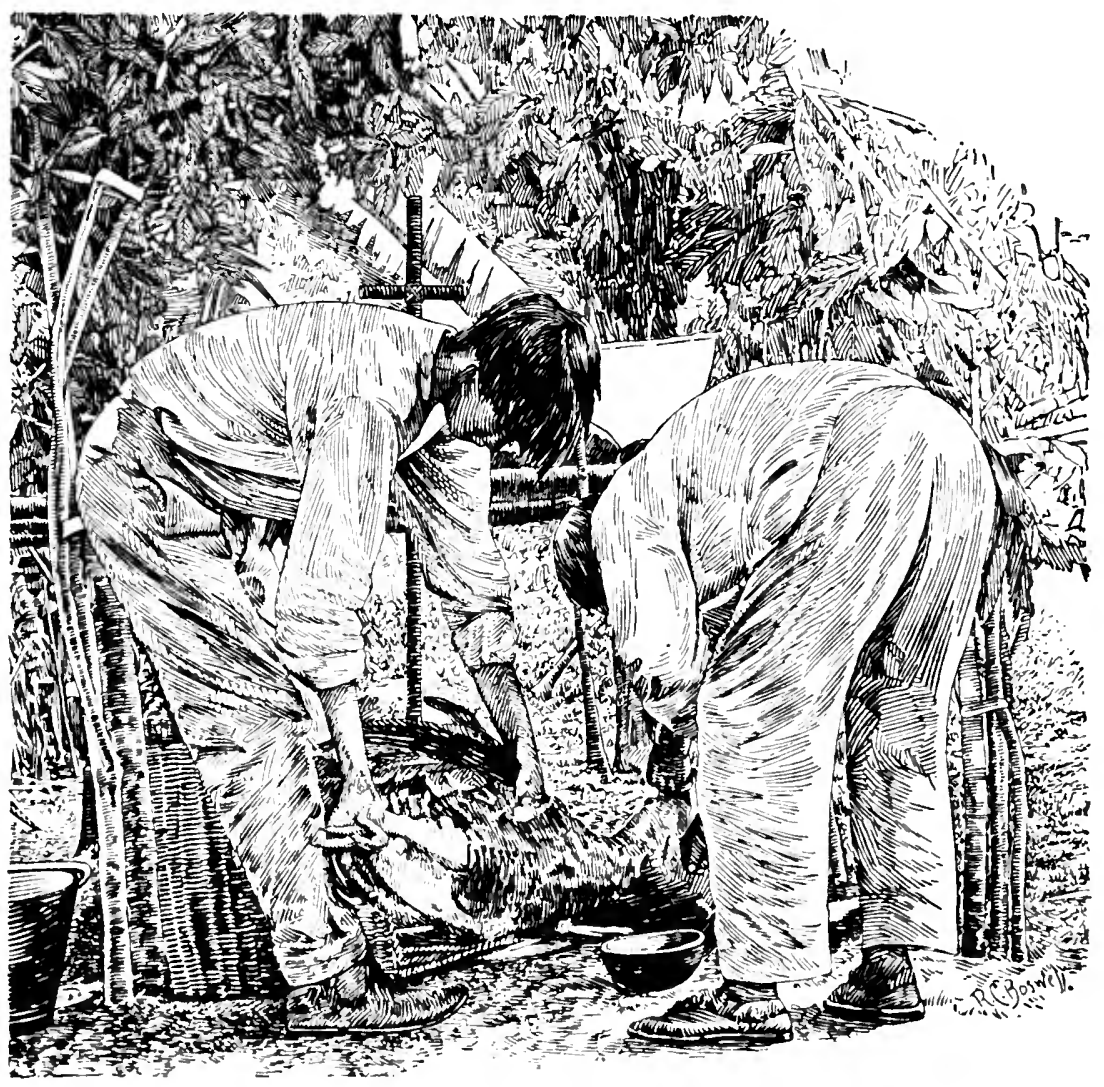

Fis. 13. -Sacrificing at turkey at the Cha chac ceremony.

oren with firewood, orer which they placed a layer of small blocks of stome. The priest next made a bowl of sachà (literally "white water," a drink made from ground eorn and water), witli which he filled

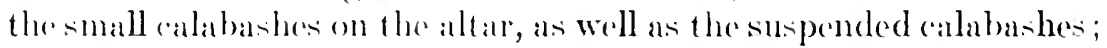
these he explained were for the tuyne pishem, or solitary souls. A turkey and four fowts were then placed in front of the altar, alive. white the priest lighterl a black wax candle by blowing a pieree of glowing woed to a llame; this candle he placed upon the altar. He next took up the turkey, around whose nerk the asistant had placed 
a wreath of jabin leaves, and poured a little balchè down its throat, its legrs being held by the assistant (fig. 13). While doing this the priest murmured the following prayer:

In kubic ti hahnal cichpan colel, ti San Pedro, San Pablo, San Franeisco.

\section{Translation}

I offer a repast to the beautiful mistress, to San Pedro, San Pablo, San Francisen.

The turkey and the other fowls were then killed by having their necks wrung, and the carcasses of all five were remored to the house to be prepared by the women. The various bundles of masa and sikit in their leaf corerings were next remored to the pib, where the fire had burned itself out, leaving the hole half full of ashes and red-hot stones. A lining of plantain bark was laid over the stones, upon which the bundles were arranged; over these were placed more hot stones and over the latter palm leaves; lastly, the earth which had been dug from the pib was raked over all. The priest next took a small quantity of the sachì from a ealabash, in a jabin leaf, and scattered it on the ground in three-directions, meanwhile murmuring this prayer:

Cin kubic ti atepaloh, ti noh yum kih yetel uahmetan, atepalob, tiaca tzib nah.

\section{Translation}

I offer to the majestic ones, to the great lord, corn cake, great ones. [Tiaca tzib nah is somewhat olscure. The reading, according to Don Juan Martinez, of Merida, should be tia ca vib-nah.]

Afterward the priest repeated the performance with sach à from the calabashes on the altar, and lastly with some from the calabashes of the tuyun pishan. The sachà was then distributed in calabashes to the participants, it being essential that every drop of it be drunk. After a wait of about an hour all proceeded to the pib, which, after it had been sprinkled by the priest with balchè from a small calabash, was opened. The red-hot leaf-wrapped bundles were carried to the small shed, where the coverings were removed, exposing the tutiua and yokua, crisp, brown, and hot. These were placed upon the altar, with the exception of one tutiua, which was tied to the string holding the calabashes of the tuyun pishan. The cakes made from the remainder of the masa and sikit were now crumbled into a large calabash and mixed with another large calabash of koot (a reddish liquid made from water, ground corn, black pepper, and achiote). The two mixtures were stirred with a peeled wand of jabin till they formed a thick paste known as sopas. While the sopas was being made the hearts, heads, and intestines of the fow's were remored to the pib where they were buried, lest some animal by eating them should defile the offering. The cooked and dismembered turkey and other fowls were brought out to the small shed in calabashes; the livers, gizzards, and immature eggs were chopped up fine and well mixed with the sopas. A small 
calabash full of this mixture was placed with the calabashes of the tuyun pishan, while the rest, in a large calabash, the fowls' claws standing upright in it, was placed upon the altar, together with the dismembered birds wrapped in a clean cotton cloth. The priest next removed some balchè from the jar and filled a calabash, which he placed upon the altar, as he did so murmuring these prayers:

Ea, in cichpan colel kanleoox, yetel bacan tech in richkelem tat yum San Isidro, ah kolkal, yetel bacan terh yum kankin, culuchalech ti likin, yetel bacan in chanttupchaac, culucbal chumuc caan, ti likin, yetel bac'an yum canchacoob; kin kubic yetel bacan ahooil atepalo chumuc caan, yetel bacan tech in cichkelem tata ahcanan kakabool, yetel bacan tech in cichkelem tata Cakaal Cxmal, yetel bacan tech in richpan colel Santa ('lara, yetel bacan terh in cichkelem tata yum xualakinik, yetel bacan tech in cichpan colel Xhelik, yetel bacin tech in cichkelem tatayum santo lorenzo, yetel bacan tech in cichpan colel Giradelupe, yetel bacan tech ton yum Mosonikoob, meyahnaheex ichil cool kat tocah. Cin kubic bacan letie Santo Gracia, utial a nahmateex, yetel hacan terch u nohchi santo uai yokol cab halibe in yumen sittes ten in eipil. Minan a tzul pachkeech letie Santo Pishan, Doki in mentic letie Santo Promicia.

\section{Translation}

Now my beautiful larly of the yellow-leaf breadnut, as woll as yon, my handsome father San Isidro, tiller of the earth; as well as you, lord sun, who art seated at the east; as well as you, (hanttupchaale, who art seated in the midlle of the heavens. in the east; as well as you, Yumcanchaacoll): I deliver to you, with the majestic servants in the middle of the heavens. As well as you, my handsome father, Aheanankakabool; as well as you, my handsome father (akaal Ixmaal; as well as you, my. beantiful lady Santa ('lara; as well as you, my handsome father Xualakinik; as well as you, my beatiful lady Thelik; as well as you, my handsome father San Iorenzo; as well as you, my beautiful larly of Guarelupe; as well as you, Lord Mosonicool, that blows within the milpa when it is burnt. I deliver then to you this Ifoly Grace. that you may taste it, and because you are the greatest Santos on earth. That is all my master. Pardon my sins; you have not to follow tho holy souls, because I have made this holy offering.

Cin Kubic ti nah tatail, ti u cahil San Ropue, u cahil Patchacan, ti chan Sapote.

\section{Translation}

I offor you, great father, for your town of Sun Roque, your town of Patchacan, and ('han siapote.

The asistant then brought up) some burning incense (pome) on a piece of plantain bark, which the priest took, and after waving it about for a short time placed it upon the altar. after which he dipped out a small portion of balche and soattrered it in thror directions, murmuring while doing so the following prayer:

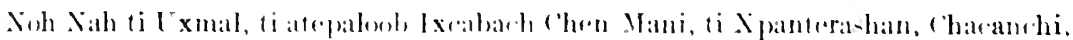

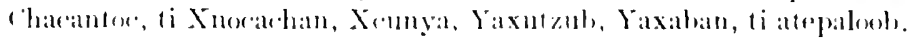

\section{Trarstation}

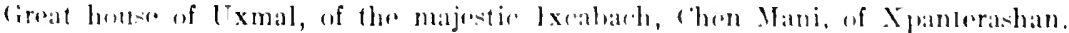

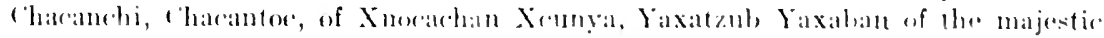
ones. 
A small portion of balchè was next passed around to each of the participants, the priest again scattering a little on the ground and repeating the prayer. The calabash, which was now nearly empty, was then removed to the house for the benefit of the women. It was soon brought back by the assistant and refilled from the jar, and the same procedure gone through again. 'This was repeated till no more balchè remained to be drunk. 'The priest then scattered some of the sopas in four directions, using one of the fowls' claws to scoop it up from the calabash, after which what remained of the sopas was divided up among the participants, each one being given a calabash in which a fowl's claw was placed for use as a fork. A small quantity of the mixture which remained was taken to the house for use of the women. Lastly the priest removed the tutiua and yokua from the altar, and divided these among the participants, giving each one at the same time a corn-husk cigarette. The ceremony was now finished, and the last act was completely to destroy all the objects used in it, including buildings, altar, calabashes, and chuyubs; this was done by fire.

This Cha chac ceremony as performed by the Santa Cruz and Icaichè Indians bears a strong resemblance to certain ceremonies performed before the conquest, in honor of the Chacs, or Rain gods, and also to ceremonies carried out at the present day by the Lacandon Indians.

The names given to the modern priests were, according to Landa, all in use in his day. The Chacs were four old men chosen to assist the priests. ${ }^{1}$ The men was an inferior priest or sorcerer, while the name Ahkin ${ }^{2}$ wis applied after the conquest, both to their own and to Christian priests by the Maya. Landa also mentions (Chap. xL, p. 260) a fiesta given to the Chacs, in conjunction with other gods, held in one of the plantations, when the offerings were consumed by the people after being first presented to the gods; these offerings consisted of turkeys and other fowls, corn cake, sitit, and posol, ${ }^{3}$ all of which are used in the molern Maya (ha chac.

The god Yumcanchacoob (Lord of all the Chacs) of the Santa Cruz probably corresponds to Nohochyumchac (Great Lord Chac) of the Lacandones, as does the Ahcanankakabol (keeper of the woods) of the Santa (ruz, to the Kanancash of the Lacandones, whose name has practically the same significance. A belief in Xtabai, or spirits, and Ihoob, or Wind gods, seems common alike to the Santa Cruz, the Lacandones, and the Indians of Yucatan.

1 "Los chaces eran quatro hombres ancianos elegidos siempre de nuevo para ayudar al sacerdote a bien y complidamente lazer las fiestas."-L.1vi.l, op. cit., chap. xxvil, p. 160.

2"En contrario llamavanse $y$ se llaman oy los sacerdotes en esta lengua de Maya Ahkin, que se deriva de un verbo kinyah. que significa "sortear 6 e har suertes." - LANDA, ibid., p. $3 i 2$.

${ }^{3}$ Landa, ibid., chaps. xxxy, p. 212; xxxry, p. 222. 


\section{PART 2. MOUNI) EXCAVATION IN THE FASTERN MAYA AREA}

\section{INTRODLCTION}

\section{Classifichton of the Mounds}

In the following pages is a description of the mounds opened during the last fow yours in that part of the Maya area now constituting British Honduras, the southern part of Yucatan, and the castern border of Guatemala (pl. 7). For descriptive purposes these mounds may be divided, according to their probable uses, into six main groups:

1. Sepulchral Ilounds.-This group includes mounds which, originally constructed for other purposes, were afterwards used as burinl sites.

2. Refuse Mounds.-This group includes kitehen middens, shell heaps, deposits of waste material remaining after the manufacture of lime, and heaps of stones gathered from the surface of the grounel.

3. Foundation .Hounds. As the buildings themsolves invariably stood on the summits of flat-topped mounds, such mounds, capped with the dobris of the earlier structures, formed the bases of later ones.

4. Deforsive Ifounds.-Some of these mounds were crescent-shnped: others were in the form of a horseshoe.

5. Lookent Mfounds. - These mounds extend in ihains, at intervals of 6 to 12 miles, along the coast and up some of the rivers: they are lofty, stecp-sided, and usually form the nuclei of groups of other mounds. As a rule they contain neither human remains nor artifacts, thourh in one or two of them superficial interments secm to have berom marle at a remparatively late date.

6. Mounds of lenertain I'se.- No trate of human interment was found in these mounds. Many of then are too small at the summit to have supported buildings, and it serms probable that they are scpulchal mombls, in which no stone, pottery, or other indestructihle objects wore placed with the corpsese, and in which the bones

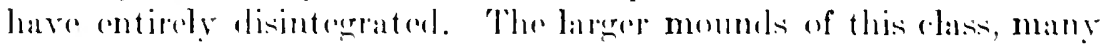
of them fhat topperl, are arofully comstrueted of blocks of limestone. mart dust, and earth, and no douht at ane time served ats bases for buildinges rither small tomples or houses which, boing huilt of word, have lenge since vamished. 
Most of the mounds are distributed in small and large groups, the latter usually containing one or more examples of each class, the former consisting for the greater part of small burial mounds, probably of late date, as they are less carefully constructed than the mounds of the larger groups, and the objects which they contain are of rougher and cruder workmanship.

The burial mounds compriso more than half of all the mounds opened, followed in order of numbers by (a) foundation mounds; (b) mounds of uncertain use; (c) refuse mounds; (d) lookout mounds; (e) defensive mounds.

It has been found that, as a rule, rich land contains many mounds; poor land, fewer; and sour-grass savannah, pine ridge, and swamp, none at all. The better the land the more numerous the mounds scattered over it, as is natural, since the more fertile the land the denser the population it would sustain. Not all the mounds opened have been described, as small burial mounds, especially in the same group, in both construction and contents, resemble one another closely, as do foundation mounds also.

This part of the Maya area must either have been occupied during a very considerable period or at one time must have supported a dense population, as wherever it is possible to cultivate the soil, especially to raise maize, mounds are to be found in great abundance; moreover, the surface everywhere bears such indestructible rubbish as potsherds, flint chips, and fragments of obsidian knives. It would probably be impossible to find anywhere in this area an acre of moderately good land on which dozens of such objects could not be discovered. This indicates that what is now dense tropical bush, with a few small Indian villages scattered through it at considerable intervals, was at one time a highly cultivated and thickly populated country.

Referring to Yueatan before the conquest, Landa uses the words: "toda la tierra parescia ull pueblo;" 1 while 200 years after the conquest Villagutierre ${ }^{2}$ mentions by name 10 tribes with whom the Itzas were at war, who lived to the east of the lagoon, nine days' journey away - in a region corresponding to the territory of coastal tribes of British Honduras and Quintana Roo.

\footnotetext{
1 Que estas gentes tuvieron mas de XX años de abundancia y cle salud y se multiplicaron tanto que toda la tierra parescia un puelolo, y que entonces se labraron los templos en tanta muchedumbre, como se vee oy en dia por todas partes y que at ravesando por mon tes se veen ent re las arboledas assientos de casas y edificios labrados a maravilla.-LAN1), op. cit., p. 58.

${ }^{2}$ Que en $A$ ños passados tuvieron quatro Batallas con los Inclios Aycales (que son los Mopanes) Chinamitas, y Tulunquies, $y$ Taxchinchán, Noh, y Acahob, Zuacuanob, Ahtimob, Teyucunob, Ahchemob, Ahcamulol, ... y que todas estas Naciones estavan viviendo juntas al Leste, ú Oriente, y que de aquél I'eten, át sus Pohlaciones, avia nueve dias de Camino, que era cl que ellos gastavan en ir á ellas.-Villagutierre, Historia de la conquista de la provincia de el Itza, p. 554.
} 


\section{Ancient Inhabitants of the Region}

From the contents of the mounds we are able to deduce many valuable facts relating to the physical appentance, social life, religion, and art of the forner inhabitants of this aren.

\section{PIIYSICAL APTEARANCL}

A very aceurate idea of the physical appearance of these people may be derived from the figurines, paintings, stuceo moldings, and skcletons found in the mounds. It would appear that they very elosely resembled the modern Maya Indians.' They were broad of face, with small features and rather high eheek bones; without beard or mustache, but with straight, black, coarse hair, which was allowed by both men and women to grow long.

The skull was naturally brachicephalie, and as this characteristic was (and is now by the Maya) admired, it secms to have been almost invariably accentuated artificially by pressure applied over the occipital and frontal recions during early infancy. ${ }^{2}$ The average cephalie index of eight skulls removed from the mounds was found to be 110 . The following list gives the average longths of a mumber of bones of adults taken from the mounds, though in no atse wore all the bones of one indiridual found in a sufficiently perfect condition to permit of their aceurate meisurement:

Ilumerus, $29.21 \mathrm{~cm}$.

Llina, 25.38 cm.

First phalanx (little finger), 3.04 ram.

Fenur, $36.83 \mathrm{~cm}$.

Tili,il, $33.27 \mathrm{~cm}$.

Metatarsil bone of great toe, $5.33 \mathrm{~cm}$.

The bones are small, the riclges for muscular attachment not well matked, and the phalingere, metacarpal, and metatalsal bones small and delicate, indicating a body with rounded contours, poor muscular derelepment, andi small extremities. 'The front teeth in some cases wore filed, in others filled with round pluges of obsidlian, iron prerites, or. jarleite, for ormannentill purposics.

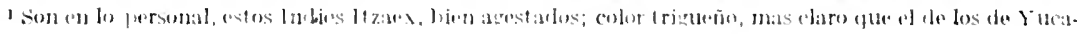

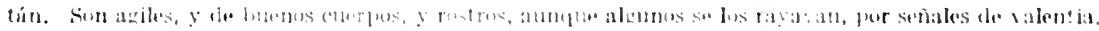

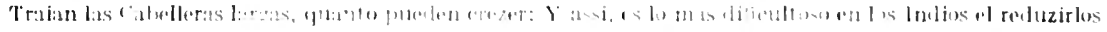

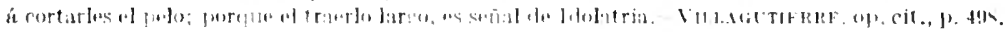

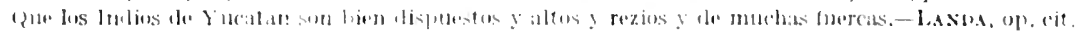
112

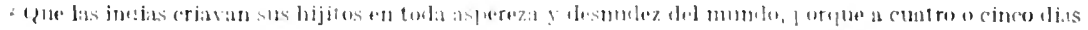

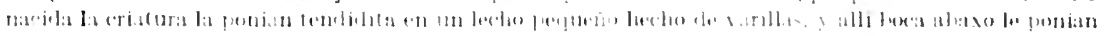

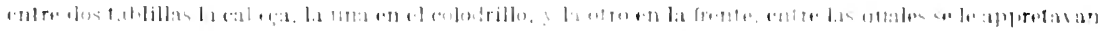

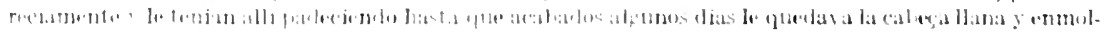

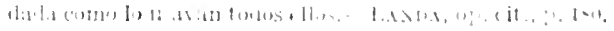


DRESS

Among the lower class the men seem to have worn no garment except the maxtli, eonsisting of a loin-cloth wound several times around the waist, the ends hanging down in front and behind, like small aprons. The women wore two garments, similar to those of the modern Maya, the huipil, or loose, sleeveless upper garment reaching to the hips (at the present this is worn longer, reaching well below the knees) and a short, loose skirt, both of cotton, and both embroidered in eolors at the borders.' The warriors wore in addition to the maxtli a breastplate of thick quilted cotton, saturated with salt, arrow and spear proof, and ornamented with bows, studs, and tassels. To its upper border was attached a hollow bar, through which passed a cord, continued round the back of the neck, holding the breastplate in place.

Both warriors and priests wore very elaborate headdresses. Those of the former were decorated with plumes of feathers and many of them held in front the head of some animal carved in wood, ${ }^{2}$ as the jaguar, eagle, peccary, snake, or alligator. Some of the headdresses of the priests were shaped like a bishop's miter, while others resembled the Egyptian headdress. All classes wore sandals of leather or platted henequen fiber. The ornaments worn consisted of large circular ear phugs of shell, greenstone, or pottery, many with a tassel dependent from the center; studlike labrets at each side of the mouth; and oceasional triangular ornaments attached on each ala of the nose. Round the neck were worn strings of beads, some in the form of human or animal heads, others with a gorget of greenstone or shell in the form of a human mask dependent from them. Wristlets and anklets of large oval beads, fastened with ornamental loops, were common, and copper finger rings have been found on two. occasions, though it is possible that these may not hare been introdueed till after the conquest. Among the upper classes the ornaments were made from jade, greenstone, iron pyrites, obsidian, mother-of-pearl, and copper; among the lower, from pottery, shell, and stone.

\section{WEAPONS}

The offensice weapons of the natives here dealt with consisted of flint and obsidian tipped arrows, ${ }^{3}$ javelins, and spears, flint and stone

1 Sus vestirurus, de que varan, eran vnos $A$ yates, 6 Gabachas, sin Mangas, y sus Mantas, todo de 1 Irodón texido de varius colores: $Y$ ellos $y$ lus $\mathbf{M}$ ugeres, vnas como Faxas, de lo mismo, de cosa de quatro varas de largo, y vila tereia de ancho, con que se çeñian, y cubrian las partes; y algunas al canto, ú orilla, mucha l'lumeria de colores, (fue era su mavor crala.-Villa gutierre, op. cit., p. 498.

2 Tenian alrunos señores y capit anes como moriones de palo y estos eran pocos, y con estas armas ivan a la guerra, y con plumajes y pellejos rle tixres, y leones, puestos los que los tenian.-Landa, op. cit., p. 172.

3 Y en las orillas de la l'laya, solo se veíun amontonadis la mult itud de Flechas, que la resaca de las olas avia llevalo á Tierra. De atonde se puefe inferir, quan inmenso seria el numero de ellas, que los Infieles arrojaron á los Pobres Christianus.-Vil. I.AGUTIERRE, op. cit., p. 483. 
axes, with slingstones, and stone-hended clubs, made for the most part of hard limestone. Their clefensive woapons were small circular shields of leather-covered wickerwork and thick cotton breastplates.

\section{rOUSES}

The lower elasses probably lived exclusively in thatehed pimentowalled houses, identical in construction with those used by the Maya of the present day; naturally, these have completely disappeared, but the former sites of villnges composed of such huts may ensily be recognized by the presence of half-choked wells and the great number of malacates, broken pots, weapons, implements, ornaments, and rubbing stones, which are to be found seattered all over them. The priests, caciques, and upper classes doubtless lived in the stone houses, the remains of which lie buried in considerable numbers in the mounds. The walls of these houses were of stucco-covered stone und lime, the floors of hard cement, and the roofs, no doubt, of beams and thateh, as many of them are too wide to have been covered by the so-ealled "American arch."

Many of these buildings were doubtless used as temples, but probably the majority of them were private houses.' In one of them an interment had taken place beneath the floor of the house before the structure was destroyed. ${ }^{2}$

\section{ARTS}

The former inhabitnnts of this part of the Maya area do not seem to have fallen far behind those of northern Yucatan in the ants of sculpture upon stone, stueco molding, mural painting, ceramics, and the manufacture of stone implements and weapons, us excellent (r.samples in all these fields have been founc!

It Sabibal, Hohmul, Narnnjo, and Bencpue Viejo, cities of the old Empire lying along the Brit ish I lomelums-(iuatemala front iere c.xamples of souptured stolie and altars have been fomml, equal in fineness of workmanship to those found at any other site within fla Marn aren.

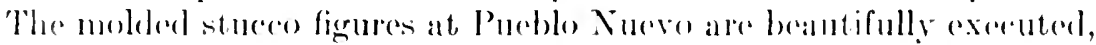
while the painted stuece upon the temple walls at santa lita is probably the finest example of this kind of deroration vert broughte to

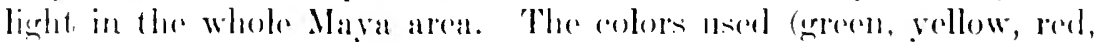

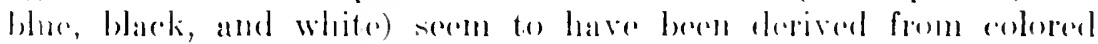

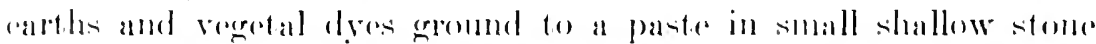

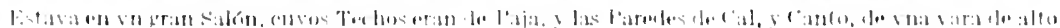

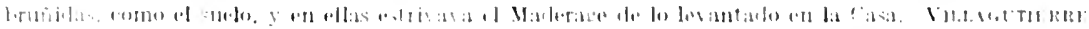
(i) $111 ., 11.3 \% ?$.

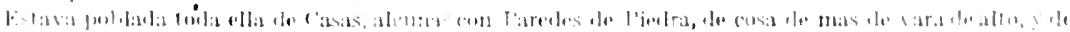

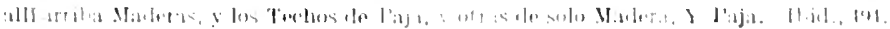

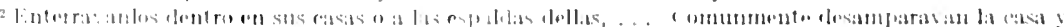

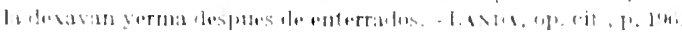


mortars with spatulate flint grinders, which have been found with traces of paint still adhering to them. Ornaments in the form of human and animal faces and heads nicely cut from jadeite and greenstone are not uncommon. Some bear incised hieroglyphic inscriptions. The greenstone shell from Kendal, described later on, in its fineness of finish and accurate imitation of the natural form, is a remarkable example of gem cutting.

Most of the domestic pottery used was of a rather coarse hard red ware. This comprises large amphora-like water jars, shallow dishes, saucers, and bowls, used probably to hold food; cooking pots of various sizes and shapes, chocolate pots with upright spouts, and disks for baking tortillas. In addition to these, thick brittle vessels of very coarse pottery, some of exceptionally large size, are found, which were probably used as receptacles for com, beans, pepper, and other light dry substances. Of the finer kinds of pottery some are ornamented with incised devices, executed after the vessels had been fired, others are covered with derices in polychrome, and still others with ornaments molded while the clay was plastic. Lastly, these three methods, or any two of them, may be combined in the decoration of any one vessel.

The objects most frequently depicted on the vases are human heads, simple glyphs, animal and mythological figures, and flowers. Most of the vessels are polished, some of them to a high degree, but the art of glazing does not seem to have been understood. The finer kinds of pottery are thin, tough, light, and very hard. The appliqué work, displayed best in incense burners, upon which the figure of the god in ligh relief is built up bit by bit, is rather coarse, but in some examples very effective. Stone implements and weapons of great varicty have been discovered, including ax, spear, javelin, and arrowheads, knives, clubs, throwing stones, hammerstones, scrapers, chisels, borers, paint and corn grinders, fiber cleaners, and many others. Flint, chert, obsidian, greenstone, and limestone were the materials most commonly used in the manufacture of implements and woapons. Very remarkable eccentrically shaped objects, inrluding crosses, crescents, rings, and a variety of other forms, chipped with great care and precision, from flint, chert, and obsidian, are also found, though not in great numbers. They seem to be confired almost exclusively to this part of the Maya area.

\section{MISICAL, INSTRUMENTS}

With the exception of clay whistles of from one to four notes, no musical instruments have boen found in the mounds, unless the hollow crlinder (10 $\frac{1}{2}$ inches high by 4 inches in diameter) from Yalloch may be regarded as a small hand drum similar to those men- 
tioned by Landa as having been in use at the time of the conquest, ${ }^{1}$ and somewhat resembling the clay jar with a piece of gibnut hide stretched orer the opening for a head, still in use as a drum among the Lacandones. ${ }^{2}$ The late Sir Alfred Moloney obtained in the village of Succots a tunkul, or wooden drum, with two rubber-tipped drumsticks, which had been brought by the Indians from Guatemala at the time of their emigration from that country. This had been handed down from Alcalde to Alcakle from time immemorial, and was used to summon the villagers on special oceasions, as a fire or the election of new Alealdes.

\section{FOOD}

The staple article of diet among the ancient Maya seems to hare been maize, as it is at the present day among their descendants. Numbers of rubbing-stones and rubbers, both broken and whole, are found in the mounds, as are also the clay disks used for baking corn cakes. The bones of various animals, which had probably been used for food, are also found; among these are the peceary, gibnut, armadillo, puma, tapir, and manatee, together with woula (snake), alligator, and (of birds) the curassow and wild turkey. Shells of the conch, cockle, oyster, and fresh-water suail are also found in abundance. The Maya probably kept small domestic animals and birds, ${ }^{3}$ as great numbers of rough stone troughs are found in the mounds, precisely similar to those mamufactured and used by the modern Maya Indians for watering their fowls, while eggs, with turkers and other birds, have been found, held in the hands of figurines upon the incense burners, as offerings to the gods. They seem to have made periodical expeditions to the cays and islands off the coast to fish and collect shellfish, as quantitios of net-sinkers, flint chips, potsherds, and broken javelin heads are found on many of the cays. But fow monnds, however, which give evidence of permanent humnn occupancy have been discovered in this situation.

\section{SIINING ANI) WHAVING}

Judering by the grent mumber of spindle-whorls foumd in the mounds and on villare sites, cotton spinning must have been practically universal among the women. Oval perforated stones of a size suitable for loom wrights halve been found, and it is probable that

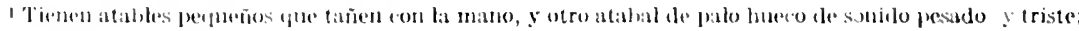

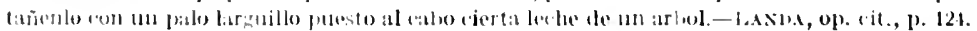

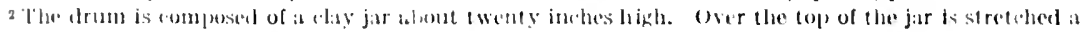

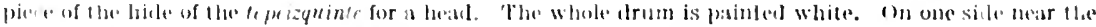

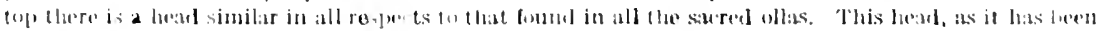

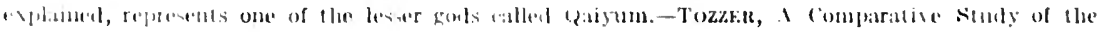

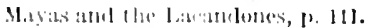

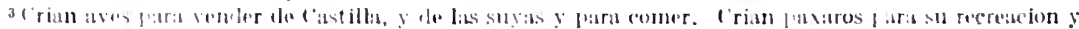

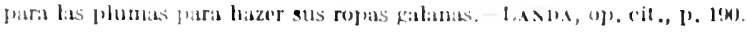


they were used as such, as they do not seem to be adapted to any other purpose. With this exception we learn nothing of the art of weaving from the contents of the mounds. Henequen fiber was doubtless used for the manufacture of rope, mats, hammocks, and other objects, as grooved flat stones for beating the pulp from the fiber are common.

\section{GAMES}

The appliances for at least two distinct games have been found. ${ }^{1}$ The first consists of a large spherical block of limestone, nicely polished, and about 1 foot in diameter, found associated with 6 to 12 smaller spherical stones, each about 3 inches in diameter, of very light material somewhat resembling pumice stone. The second consists of a number of small disks of shell, about three-fourths of an inch in diameter. Collections of these have been found together on several occasions; they might have been used as beads or ornaments but for the fact that they are neither perforated nor decorated with incised figures as shell beads usually are.

\section{RELIGION}

Of the 15 gods of the codices classified by Schellhas five may be recognized in this area with a fair degree of certainty. God $A$, the god of death, in the form of a human skull, decorates the outside of not a few small pottery vessels, and is depicted upon the painted stucco wall at Santa Rita. God B, the long-nosed god, is usually identified with Cuculcan. Representations of this god are found throughout the whole area in great abundance, painted upon pottery and stucco, incised on bone and stone, and modeled in clay. This god is associated with the cities of Chichen Itza and Mayapan, and is supposed to have entered Yucatan from the west; indeed it is possiblo that he may originally have been the leader of one of the Maya immigrations from that direction. He appears to have been by far the most popular and generally worshiped deity in this area, and it is his image which is found on nearly half of all the incense bumers discorered. God D, probably Itzamna, appears in the codices as an old man with a Roman nose, shrunken cheoks, toothless jaws, and-a peculiar scroll-like ornament beneath the eye, to the lower border of which are attached two or three small circles. In some representations a single tooth projects from the upper jaw, and in a few the

\footnotetext{
1 Por lo quil se usava tener en cada pueblo una casa grande $\mathrm{y}$ encalada, abierta por todas partes, en la qual se juntavan los moros para sus passatiempos. Jugavan a la pelota y a un juego con unas habas como a los clarios, y a otros muchos.- l AANDA, op. cit., p. lis.

Two curious stones, whieh may have been used in some game, were discovered in a small burial mound in the Orange Walk district of l3ritish llonduras some years ago. They were mate of nicely polished crystalline limest one, about one foot in diameter, and shaped very much like curling stones without handles. The upper part of each was traversed by two round holes, about one inch in diameter, which passed completely through the stone, near its summit, and crossed each other at right angles.
} 
face is bearded. This god is not infrequently found associated with the serpent. A typical representation of him is seen upon the Santa Rita temple wall; ${ }^{1}$ here he is depicted standing upon intertwined serpents, holding in his right hand a feather-pluned serpent. This god is represented upon some incense burners, and is found not infrequently associated with Cuculcan.

God $K$, the god with an elaborate foliated nose, of en closely associated with God $B$, his face in some cases forming the houddress ornament of the latter god, is unmistakably depicted upon the Santa Rita temple wall." God P, the Frog god, is found on some small pottery vases, and on a few incense burners. Nothing found in the mounds proves definitely the practice of human sacrifice in this area, but that it existed is almost certain, as Villagutierre refers to it as prevalent among the Itza of Peten at the time of their conquest, ${ }^{3}$ at the end of the seventeenth century, and Landa mentions it as occurring among the Maya at the time of the coming of the Spaniards. ${ }^{4}$ Near the headwaters of the Rio IIondo a mound was opened, which contained, in a stone-walled chamber, a number of human skulls unaccompanied by other bones. It is possible that these may have been the remains of sacrificial victims, as it was customary to remove the head of the victim after death, which became the perquisite of the priests.

Human sacrifice among the Maya was probably a somewhat rare event, taking place only on extraordinary special occasions, as in times of public calamity - for example, during the prevalence of famine, war, or pestilence-when it was folt that a special propitiatory offering to the god was called for. This practice was confined to one, or at most to a very small number of victims, never reaching the proportions which it did among the Aztec, by whom it was probably introduced into Yuratan. The main offering of the Maya to their gods seems to have eonsisterl of an incense composed of copal gum and aromattic susbtances. Landa mentions this as largely employed at the time of the concpuest: Villagutiere encountered it among the ltza at the end of the seventeonth century; and Tozzer found it in use among the Lateandon Indians at the present day. The incerse itself has berol found all over this area, as woll as great numbers of incenae burners.

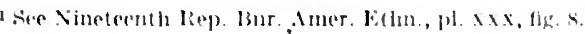

2 hidl., pl. $\mathrm{x} \times 1 \mathrm{x}, \mathrm{nos} .3 \mathrm{~s}$

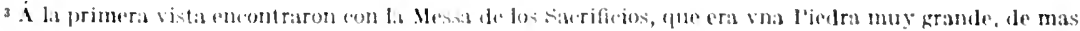

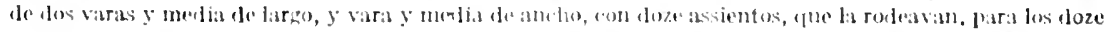

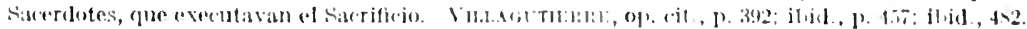

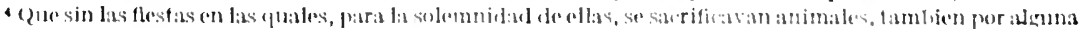

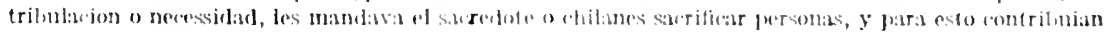

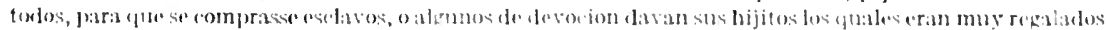

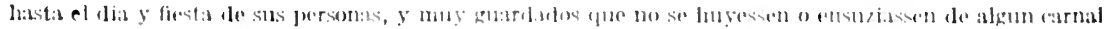

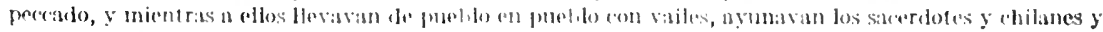

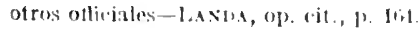


In addition to incense, the blood of fish, birds, and animals was smeared over the images of the gods, as an offering, together with human blood obtained by cutting the ears, tongue, genitals, and other parts of the body. The hearts of various animals, together with live and dead animals (some cooked and some raw) and all kinds of foods and drinks in use among the people, ${ }^{1}$ were also employed as offerings to the gods. In the hands of figurines upon the incense burners are found, modeled in clay, fruit, flowers, eggs, cakes, birds, small animals, and other objects, all evidently intended for the same purpose.

\section{CIIRONOLOGY}

Three distinct periods of Mayan civilization scem to be represented in this area. The center of the earliest of these was along the Rio Grande, in southern British Honduras, within 20 miles of the Guatemala frontier, where the Leyden Plate was discovered, upon which is inscribed the earliest but one known Maya date-namely, Cycle 8, Katun 14, Tun 3, Uinal 1, Kin 12. If the massive stone-faced pyramids and terraces of these ruins are contemporaneous with the Leyden Plate, as seems possible, they must be reckoned among the earliest monuments of the first, or southern Maya, civilization. The Benque Virjo temple, in the extreme western part of British Honduras, comes next in point of time. This was almost certainly contemporaneous with its near neighbor, Naranjo, where the earliest Initial Series found is 9.10 .10 .0 .0 , and the latest 9.19.10.0.0, giving the city an age of at least 9 katuns, or 180 years. It will be seen that the difference between the Leyden tablet date and the eurliest recorded date at Naranjo is rather more than 16 katuns, or 320 years.

The latest of all the sites is undoubtedly Santa Rita, which shows strong Mexiean influence; this belongs to the second era of Maya civilization, which reached its highest development in Iucatan and the northern cities. Excluding the Tuluum Stela, the date upon which, 9.6.10.0.0, is almost certainly not contemporaneous, ${ }^{2}$ the only Initial Series deciphered with certainty in Yucatan up to the present time is that at Chichen Itza, 10.2.9.1.9, nearly 3 katuns, or 60 years, later than the latest at Naranjo; but probably the Santa Rita site is nuch later in clate than this, and if we may juclge by the objects found in the mounds in the vicinity, some of which show strong Spanish influence, it was occupied up to and beyond the conquest.

\footnotetext{
I Mas de todas las cosas que aver podian que son aves del cielo, animales de la tierra, o peseados de la agua, siempre les embadurnavan los rostros al demonio cor la sangre dellos. Y otras cosas que tenian ofrecian; a algunos animates les sacavan el corazon y lo ofrecian, a otros enteros, unos vivos, otros muertos, unos erudos, ot ros guisulos, y hazian tambien grandes ofrendas de pan y vino, y de todas las maneras de comidas, y hevidas que usaran.-LANis, op. cit., pp. 162-164.

${ }^{2}$ Rceent examination of the Tuluum Stela has brought to light upon it, in two places, the glyph representing the lahuntum, and the dite 7 . Ahau; now 7 thau oceurs as a lahuntun ending in 10.6.10.0.0 (approximately $695 \mathrm{~A}$. I). of our era) which is almost ecrtainly the contemporaneous date of the Stela.
} 



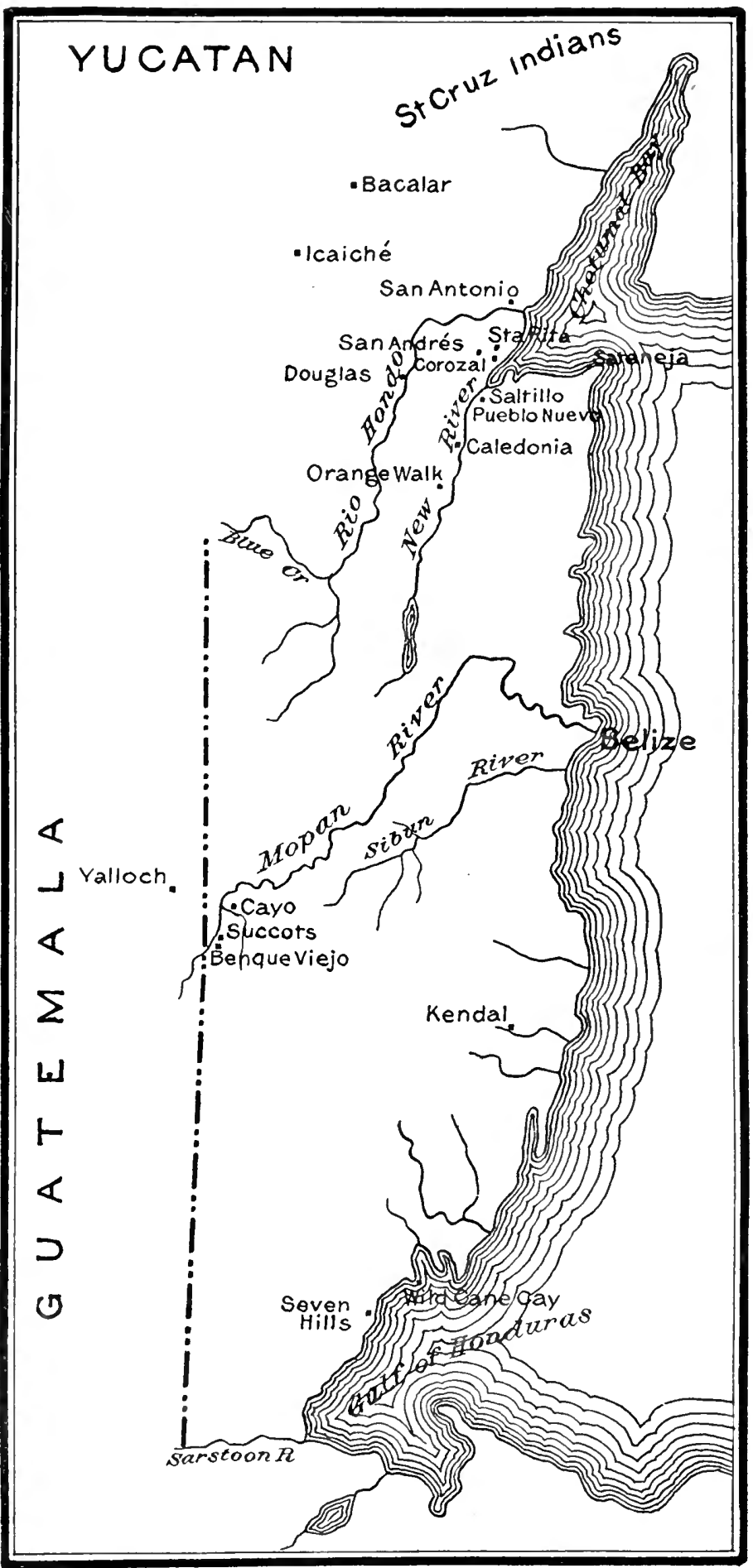




\section{DESCRIPTION OF MOLNDS \\ Mocin No. 1}

Mound No. 1 (No. 24 on the plan of Santa Rita (fig. 14), situated midway between Nos. 6 and 22 ) was conical in shape, nearly circular at the base, 18 foet high, and 90 fret in circumference. It was built throughout of large irregular blocks of limestome, the interstices being

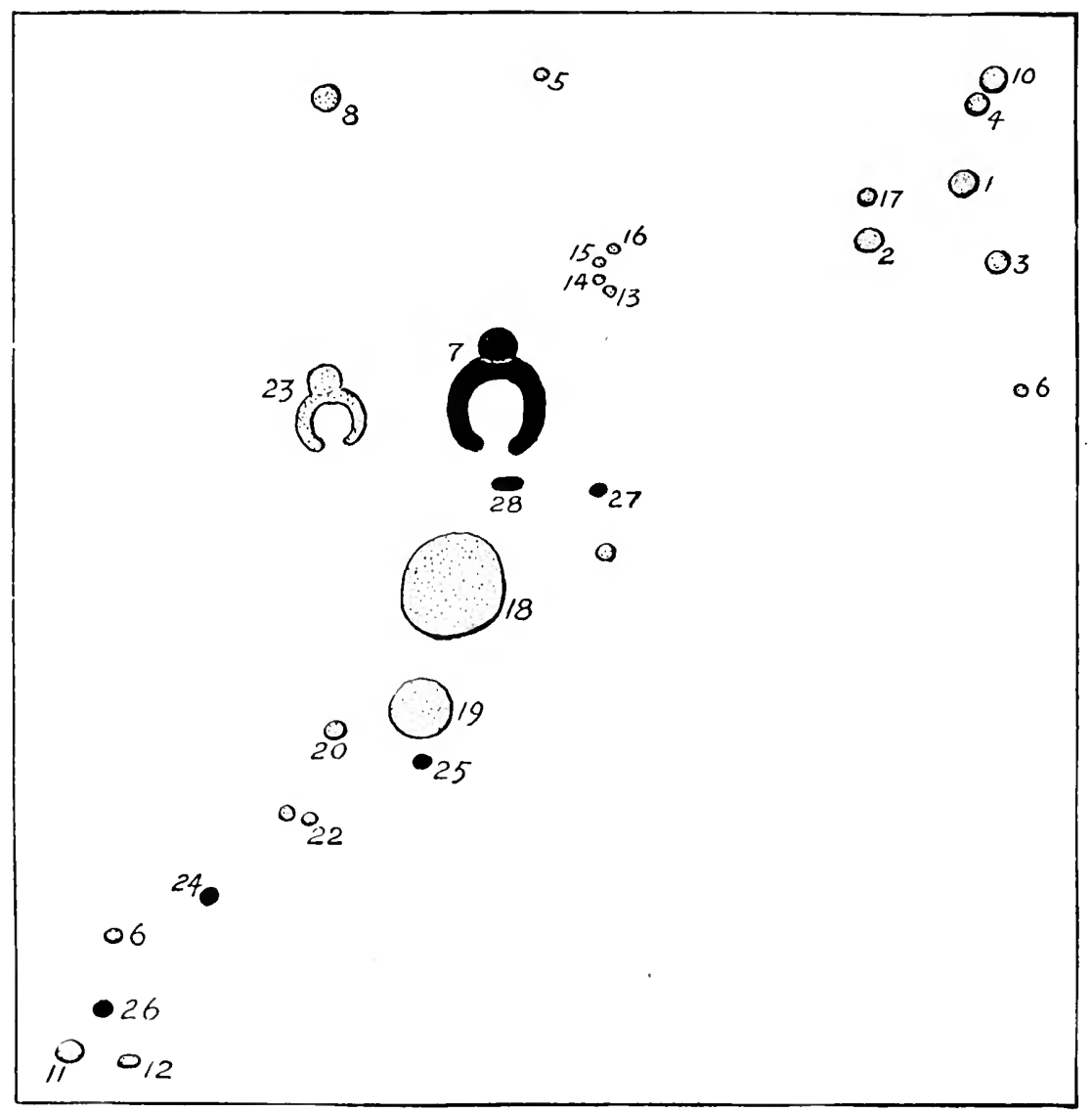

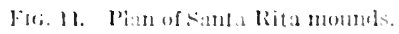

filled with limestone dust and carth, forming together a sort of friable mortan, which rembered the whole structure meary as compant as a solid blerek of masomry.

Exaration near the econter of the moumd, at a depth of 2 foet bolow

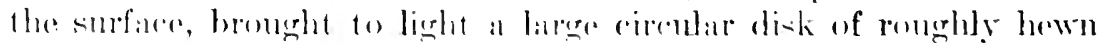
limestene, 3 fort in diameter by sinches thick. (On liftine this it was 
found to cover the mouth of a boll-like eist, nearly 3 feet in diameter and about 5 foet in depth. On opening the cist, which was slightly narrower at the bottom than at the top, it was found to be nearly half filled with rery fine brown dust, at the bottom of which lay a roughly made circular urn 18 inches in diameter, covered by a mushroom-shaped lid.

The urn was filled to the top with small crudely executed pottery figurines of men and animals. There were 49 of these in all, consisting of 4 warriors, with shiekd and spear, 3 seated human figures, 4 standing figures (eating and famning themselves), 4 lizirds, 4 alli-

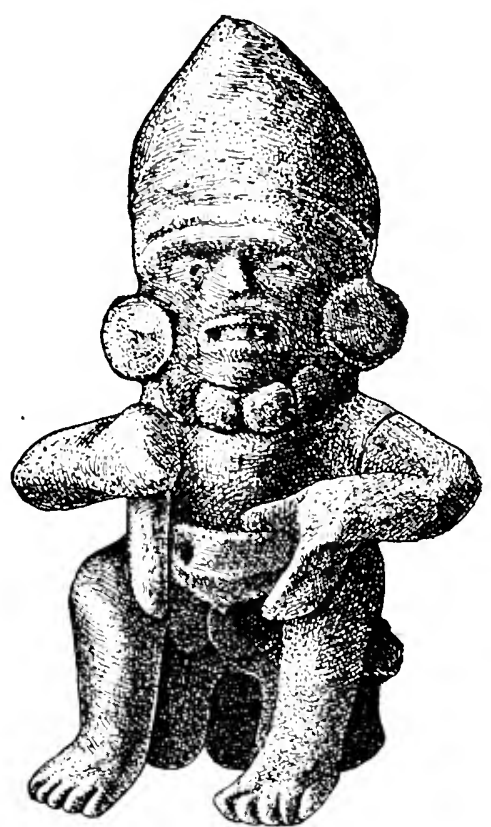

FIG. 15.-Figurine from Mround No. 1. gator's, 4 snakes, 4 birds, 4 dragonlike creatures, 4 tigers, and 14 quashes or picotes. The warriors (pl. s) are represented in a crouching position, with the right knee and left foot upon the ground; each holds in the right hand a small spear and on the left forearm a cireular shicld. ${ }^{1}$ Two of them exhibit tusk-like objects projecting from their mouths. 'The figures are $4 \frac{1}{2}$ inches high ; they are painted in red and white throughout. The headdress consists of a boat-shaped cap worn with the bow and stem projecting over the ears. The seated figures (pl. 9 ; fig. 15) are cach 6 inches in height ; these are painted throughout in red, white, and green. Each is seated upon a low four-legged stool, and grasps in one hand by its greatly enlarged spatulate glans the projecting penis, on which he is seemingly performing some sort of surgical operation with a long knife held in the other lrand.

The headdress consists of a mitre-like erection in front, with a long queue hanging down to the waist behind. Button-like labrets are worn on each side of the month in two of the figures, and all wear large circular ear phugs. The standing figures (fig. 16) are each $5 \frac{1}{2}$ inches high, and hald been painted throughout in red and white, though not much of the original color now remains. The headdress consists of a broad flat (ap) decorated in front with a row of circular beads, and on each side with a large tassel, which hangs down over the ear plugs. Each figure wears a small narrow maxtli and button-like labrets at each angle of the mouth. In one of the figures the right

1 Tenian lanitulas cortis de un extado con los hierros de fuerte pedernal . . Tenian jara su defensa rodelas que hazian de cunas henditlas, y muy texidas redondas y guarnecidas de cueros de venados.-1/ANDA, op. cit., 1). 170-172. 

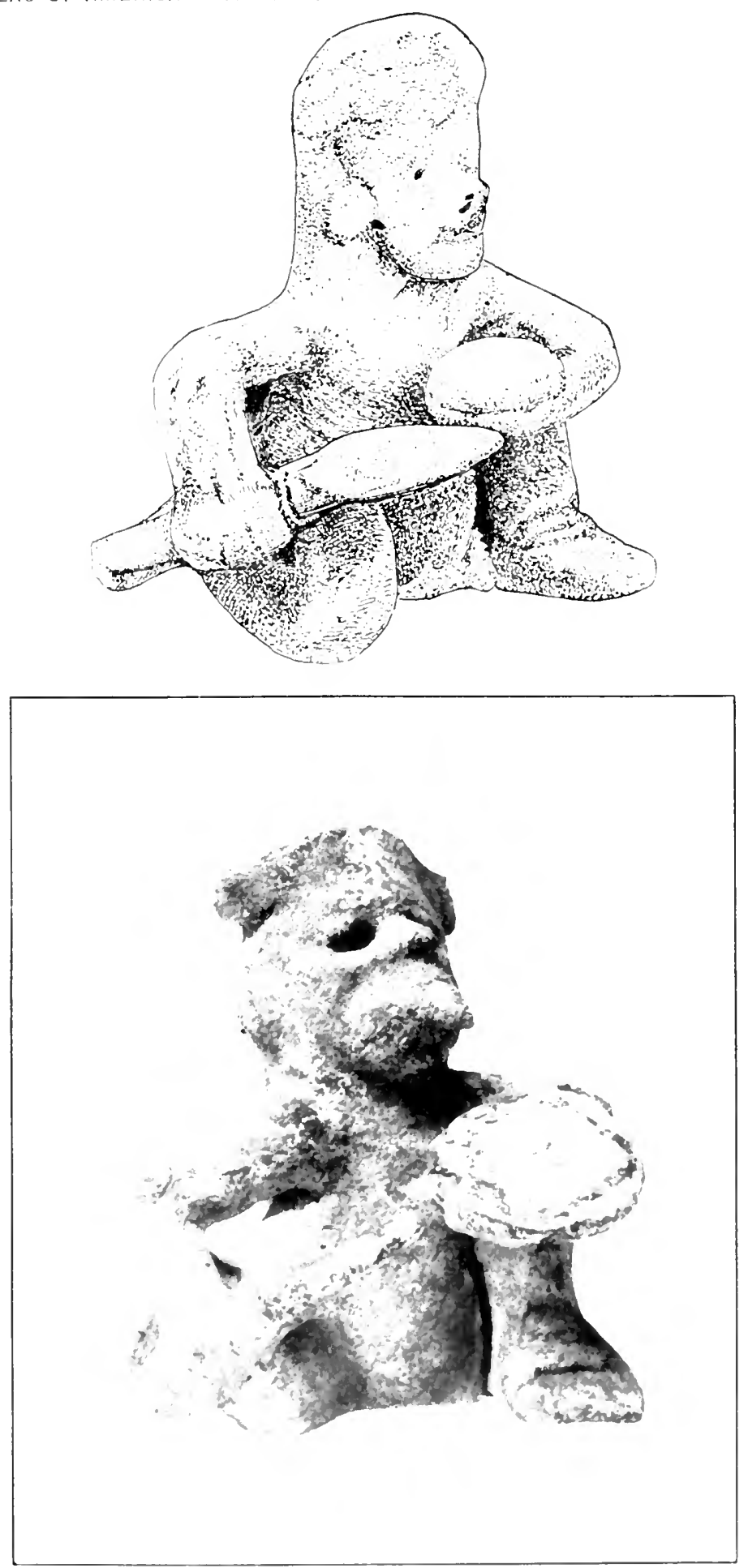

FIGOURITES OF WARRIORS FROMA MOUND NO. 

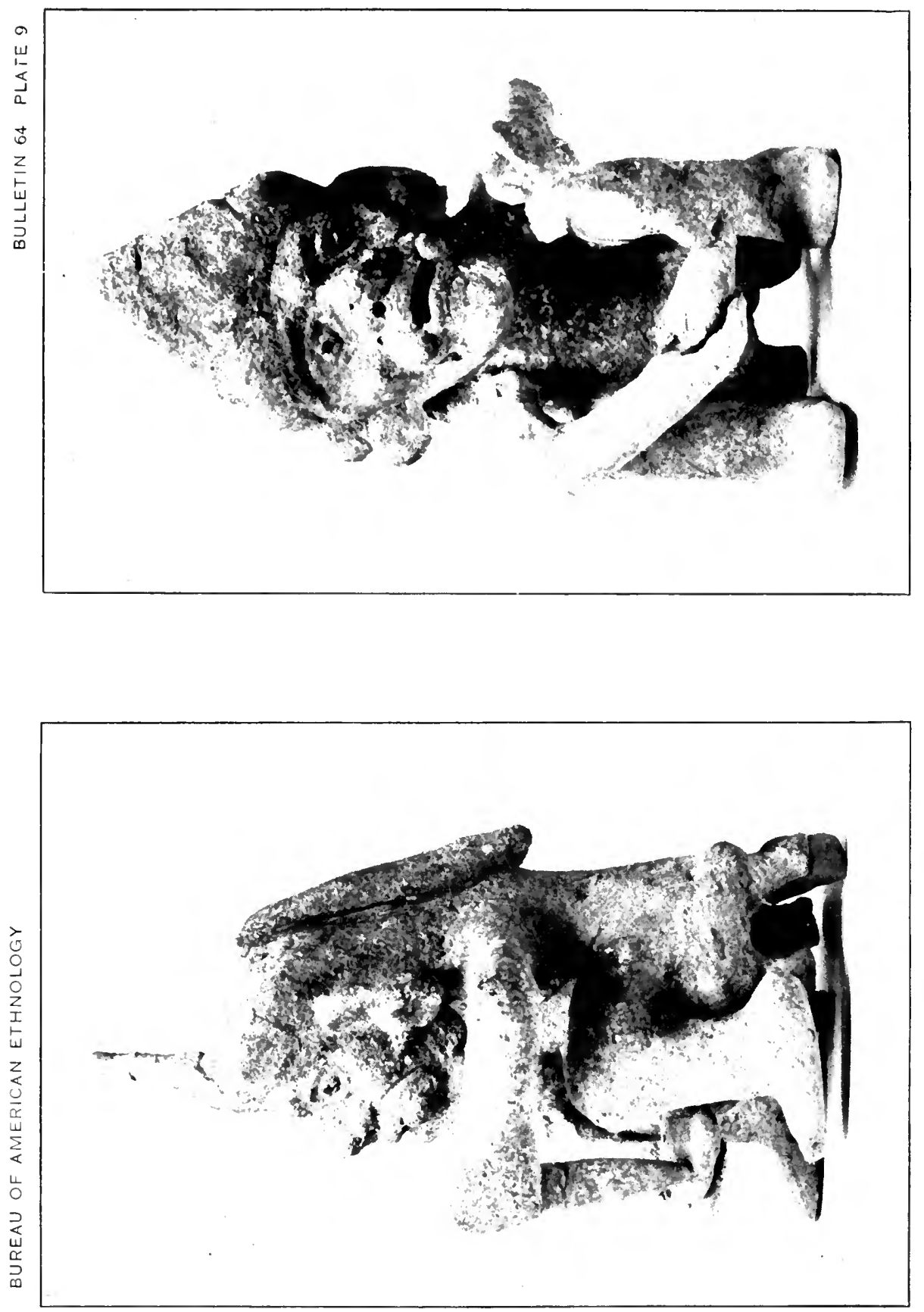
hand is extended, while the left holds a circular fan. In the other the forearms are flexed at right angles, with hands held open in front of the waist, as if about to receive something. The lizard effigies, though crudely male, are most lifelike representations about 6 inches in length. The alligators resemble very closely those taken from another mound at Santa Rita. ${ }^{1}$

The tigers and dragon-like creatures are exactly similar to those figured in Nos. 6 and 4 of the same plate. The bird and snake effigies are very crucle and ill made; the former, about $1 \frac{1}{2}$ inches in length, represent birds in the act of flying, with wings extended. The snakes, each represented with a clouble curve in the body, are about 5 inches
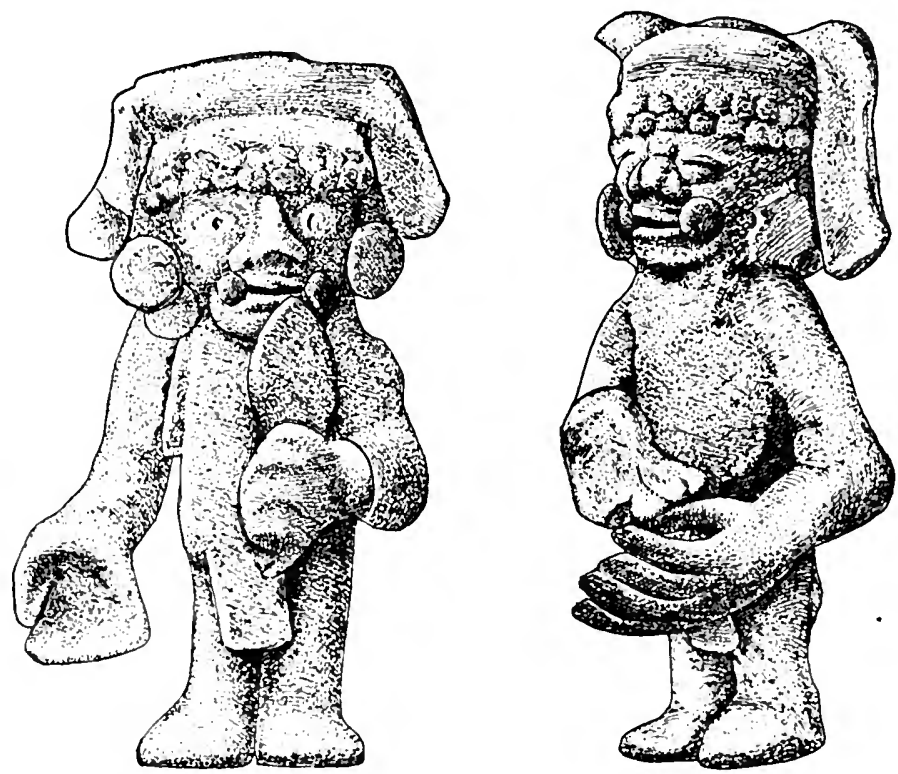

Fig. J6. Figntines from . Inumd No. I.

in length and onc-half inch in diameter: they ane made of rough risy, painted red. The ofligies of the cuatshes, though rough and crudely madre, atre rather vigorous and lifelike in exerution. Each is about 3 inches long. This small urboreal animal, which abounds in the distrive is represented in a varioty of comical positions; so well inderel has the artist studied his moeled that one an not help thinking that he must have kept some of the little animals as pets, as mamy of the Maya Indians do at the present day. The figures when first found were se brittle that it was imposible to remove them from the por withent breakiage, as they had been soemingly only sinn driol. After exposime to the sun and air, however, for a few

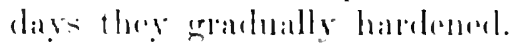


The only unpainted object found in the urn was a natural-size model of the human penis, in a state of semierection (fig. 17). This differed from all the other objects in that it had been fired, instead of merely sun dried, and is on that account much harder. Upon the upper surface of the glans penis are three longitudinal incisions, extending almost from base to apex, evidently made with a sharppointed implement while the clay was still soft.

With these figurines a number of perforated beads of jade and some of a dark-red stone, all nicely polished, were found; also the tooth of a large alligator, perforated at the base, evidently for suspension with the beads.

About 6 feet to the north of the center of the mound, at a depth of 3 feet below the surface, was discorered a small stone cist or chamber, 18 inches square, built of roughly cut blocks of limestone. Within this were found most of the bones of a male of medium height and fair muscular derelopment. These bones were

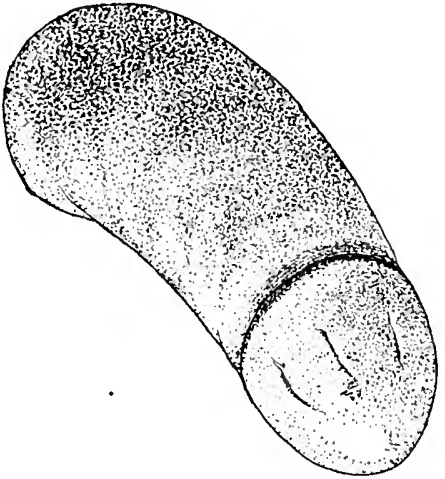

Flg. 17.- - Enpainted object from IIoundNo.1. exceedingly friable, but slowed no effects of fire; with the exception of the tibiæ, they were in no way abnormal. The upper articular surface of the right tibia had disappeared. The shaft was rounded in section, the prominent angles at the front and sides being obliterated. It was slightly bowed, with the conrexity anteriorly, and was considerably enlarged, especially in its upper two-thirds, which were composed chiefly of very friable cancellous tissue, rendering the bone much lighter than its appearance indicated. The surface of the upper part of the bone was marked by the presence of a number of small pits or depressions. Of the left tibia only a few fragments were found, but so far as could be judged from these a change somewhat similar to that observed in the right tibia had taken place in it. The bones and other objects found in this mound would suggest at first sight the possibility of the individual buried beneath it haring suffered during life from some form of venereal disease, ('losely allied to, if not identical with, syphilis. On reading Landa's account ${ }^{1}$ of two forms of ceremonial self-mutilation carried out by the Yucatecen Maya at the time of the conquest there

tolras, se harjavan to superfluo deł miembro vergonçoso, dexan lolo como las orejas, de lo qual se engaño el historiador general de las lndias, diziendo que se circumeidian. Otras vezes hazian un suzio y penoso sacrificio añulan lose los dur lo hazian en el templo, donde puestos en ren la, se hazian seaclos agujeros en los minthos virifes al soshyo for el ledo, hechos jassavan toda la mas cantidaul de hilo que nodian querlanito assi tolos asilos, y ensartados; tambien untavan con la sangre de todas estas partes al demonio y el cue mas hazia, por mas valiente era tenido.-L.Axn, op. cit., p. 162. 
can be little doubt, however, that the figurines shown in plate 9 and figure 15 are meant to represent individuals inflieting on themselves one or other of these, but, owing to the crudeness of the workmanship, it is diffieult to detemine which. In one the foreskin was pierced and expanded in much the same way that the ears were treated when sacrifieing to the idols. In the other, a number of men, sitting in a row in the temple, each piered his glm penis from side to side, and passing a long piece of cord through all the apertures, strung themselves together in this way.

\section{Motil) No, 2}

Mound No. 2 (No. 25 on the plan, fig. 14) was situated a short distance to the south of Mound No. 19. It was cireular at the base, conical in shape, 6 feet high at its highest point, and 40 rards in cireumference. On the summit of the mound, partially inuried in the earth, was found a conch shell, much worn by the weather, with the tip cut smoothly off, and still capable of being used as a trumpet. The surfuce layer of the mound was composed of arth, in which were embedded a few limestone blocks. Within this layer, which was 18 inches thick, near the conter of the mound and a fow inches beneath the surface, was found a turtle, hewn from a hlock of limestone, measuring i3 inches in length and 10 inches in breath. The next layer was composed of ashes, charreal, and piecess of half-charred wood. This layer, which varied from 3 to $s$ inches in thieknoss. extended orenly orer the whole surfare of the mound, and within it were found 16 beads of jade, two small round thres-legged vases, and the fragments of two pottery images. The beasls were all perfornted and timely polished; two of them reppesented human faces. and one the head of some animal, probably an alligator. One is unusually large, measuring 33 inches in length by 3 inch in breadth.

The clay images are so fragmentary as not to be worth figuring. but in construction. ormanentation, and size they appear to be almost identical with those found in the monnels at sintar Rita. alleady described.' One of the vases is 31 inches and the othere 2 inches in lecight: both are ovate. All the objocts taken from this

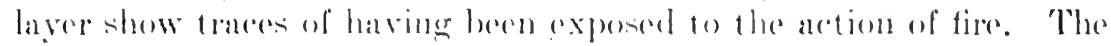
beats are all more or lesis cracked and biakened, and the pottery

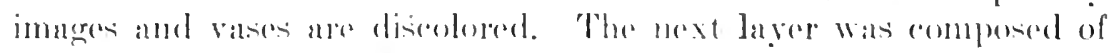

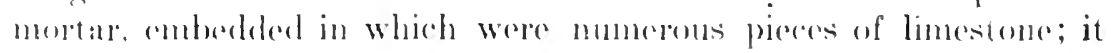

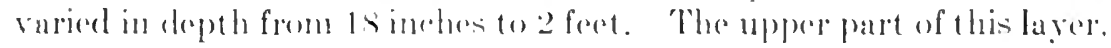

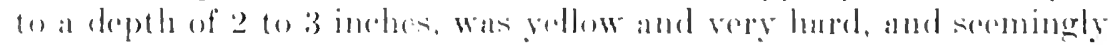

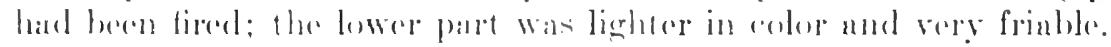

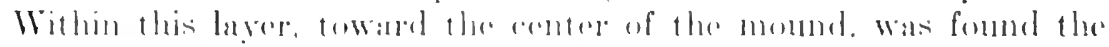


alligator effigy shown in figure 18 . This animal is $15 \frac{1}{2}$ inches in length from the snout to the tip of the tail. The interior is hollow, and in the center of the dorsal region is a circular opening $3 \frac{1}{2}$ inches in dianeter, surrounded by a rim $1 \frac{1}{2}$ inches high and covered by a saucerlike lid. Within the widcly opened jaws is seen a human face, having at each corner of the month a small pottery disk, and in the ears two large circular ear plugs. ${ }^{1}$ Between the eyes of the alligator are two claw-like horns, 1 inch in length, each terminating in three curved prongs, which point forward. Within the botly were found two small perforated beads of polished jade. The inside of the jaws is colored red; the whole of the body, together with the head and limbs, is colored brown; the forehead and cheeks of the face held between the animal's jaws are colored blue; the nose, mouth, and chin, white.

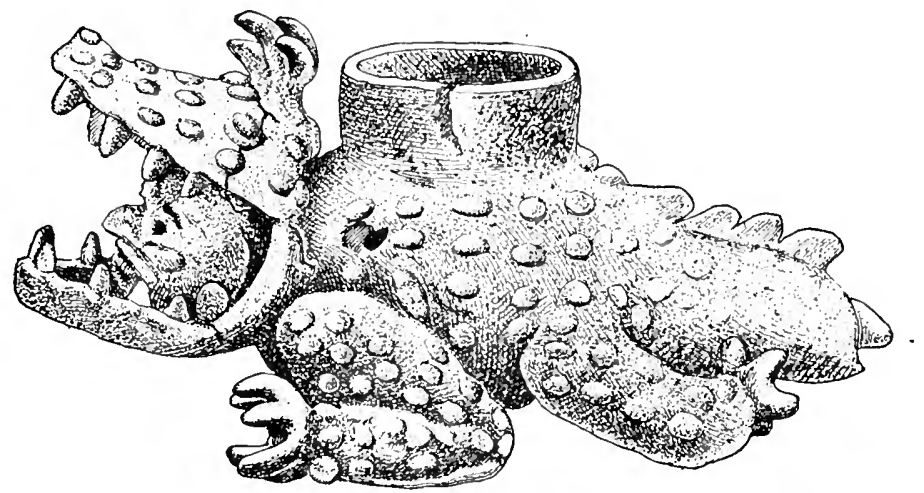

FIG. 1s. - Clay alligator found in Mound No. 2.

This is by far the largest and most carefully modeled of the pottery figurines found at Santa Rita, the smallest detail having received careful attention, and the scales, claws, and teeth being separately and accurately formed. ${ }^{2}$ Tho fourth and deepest layer was $2 \frac{1}{2}$ feet

\footnotetext{
1 These large round ear plizs seem to liave been universally worn; they are found in the paintings, on figurines, and on the incensarios. The plug may be funnel shaperl or flat, plain, or decorated with a stud, rosette, or tassel. Deseribing the ear ornaments worn by the Itzas, Villagntierre says: "Si bien muchos de ellos rayadas las caras, y ahujerearlas Ias orejas. . . . I que algunos InIIos traían puestas, en las orejas que traía vnas Rosas de Plata, y otros Ias traían de Uro; y otros de Oro, y I'lata."-VillagutierRe, oP. cit., PP. 402-103.

Landa, speaking of the Maya women, says: "lloradavanse las orejas, Jara ponerse zarzilloa al modo de sus maridos."- LANDA, op. eit., p. 1s2.

2 Figurines of animals witl lnuman heads projecting from their widely opened jaws are common in this area. The turtle, alligator, tiger, shark, and snake are usually the animals selected. Thomas says of this figure: "If we may judge from its use there is no doubt that the Iexis an cipactli figure is a symbol of the earth or underworld. The usual form of the day symbol in the xfexican codices is shown in plate Lxw, Iit, and more elatorately in plate Liv, 17." [These correspond almost exartly with some of the figurines found.] "As proof that it indiales the earth, or underwork, there is shown on plate 73 of the Jorglan Codex an individual, whose neart has been torn from his hreast, plunging downward through the onen jaws of the morster into the slade of the e:t (In helow. . . . It is therefore more than Iikely that the animat indi"ated by the Mexican name of the lay is mythical, represented acrording to lorality by some known animal which seems to indicat thest the mythical eoncept ion. Some figures evidently refer to the alligator, and others apparently to the ignana: that on plates 1 and 5 of the 1)resden Codex is purely mythieal." Thomas, Day symbols of the Ifaya Jear, 11. 212.

Spinden explains these part human, part animal, monsters differenty. He regards the human face as symbolical of the humian mind eontained within the animal body of the god. $-\Lambda$ study of Maya Art, pp. 35 and 62 .
} 
in thickness, and was built of blocks of limestone, each weighing from 50 to 200 pounds, roughly fitted together, without clay or mortar to fill in the crevices. Scattered all through this layer were great numbers of fragments of pottery censers decorated externally with human figures; nearly 150 pounds of these were taken from it, representing probably 20 incense burners. Tho whole of the pottery when first found was exceedingly brittle, but hardened in a few hours on being exposed to the air and sun. At the bottom of this layer, and resting on the ground, were found a number of pieces of black porous material with a peculiar odor. The bottom of a large round pot, 10 inches in diameter, was also found full of the samo substance, which is probably a mixture of copal gum with various aromatic substances, which had been used as incense and partially charred at the bottom of the incense burner. Fragments of the bottoms of round pots were found scattered about on the ground level, many of them having bits of this charred incense still adhering to them.

The mound appears to have been constructed in the following manner: First, a number of pieces of burning incense and round jars containing the same substance were strewn thickly over an area approximately 40 yards in circumference; next a foundation or platform $2 \frac{1}{2}$ feet in height was formed by placing together a number of large rough blocks of limestone, among which were seattered the fragments of about 20 incense burners, decorated outside with human figures in high relief. Over this was plastered a layer of mortar 18 inches to 2 feet in thickness in which was embediled the alligator seen in figure 1s. Fires were lighted on top of this mortar till its upper layers were discolored, and into the fire while still burning wero thrown fragments of two clay images, two small oval vases, and a number of beads. Over the ashes and charconl left by the fires earth and blocks of limestone were heaped to a height of 18 inches, and in this layer was buried the stone turtle already referred to; finally on top of the earth layer was placed a conch-shell trumpet.

\section{Mound No. 3}

Mound No. 3 (No. 26 on the plan, fig. 14) was situnted immediately betwern Mounds Nos. 6 and 11. It was roughly rircular in shape, 120) feet in circumference and 3 feet in beight. (On being dug away to the ground level it was found to be composed of earth and small blocks of limestonc, among which were mumerous potsherds and franmonts of terra-cotta images, though the latter wore so small that it was imposible to tell how many images they represented. The potslacels varied very much, somo boing rough and undecorated, others polished and weil painted in geometrical deviers. Fragments of flint speratheads and obsidian knives wero also found in this mound.

Tosot; $-15-$ Bull. $64-5$ 
On reaching the ground level the opening of a narrow passage 18 inches square was discovered which led obliquely downward toward the east for a distance of 8 feet; it was lined with roughly squared flags of limestone and terminated in a small stone-lined chamber 2 feet square. On the floor, half buried in fine dry earth, lay a small urn, roughly made of eoarse pottery, neither painted nor glazed. It was circular in form, $38 \frac{1}{2}$ inches in cireumference, with a semicircular handle at each side, and was covered by a mushroom-shaped lid; with the lid in situ the whole formed a somewhat irregular sphere. In the urn and almost completely filling it were 20 small pottery figurines, comprising 3 warriors, 1 seated human figure, 4 alligators, 4 dragons, 6 quashes or picotes, and 2 serpent-like creatures.

The warrior figures resemble very closely those found in Mound No. 24 (see pl. 8), the only difference being that while two of them hold shields on their left forearms, and grasp spears in their right hands (as in pl. 8), the third warrior from this mound grasps a long dagger, instead of a spear, in his right hand. The seated figure is very similar to those from Mound No. 24 (see fig. 15), the only difference being that the glans penis is grasped in the left hand while the right hand wields the knife. The alligators are closely similar to those already described, except that they are solid throughout instead of being hollow. They are painted red, white, and black, and vary in length from $5 \frac{1}{2}$ to $6 \frac{1}{2}$ inches. The tigers are similar to those found in Mound No. 24, but are rougher, and not so carefully modeled; all are hollow and are painted red throughout. The four dragon-like creatures vary from 6 to 7 inches in length; the body, which is round and slender, ends in a flattened bifid tail; the mouth, which is held wide open, is furnished with a set of formidable teeth. Upon the upper lip is a horn-like excrescence, and over the thorax are one dorsal and two lateral fins. Each animal is painted white over the whole surface; the inside of the mouth is painted red over the white layer. The six quashes are exactly similar to those found in Mound No. 24, as are also the two serpents.

Mounds containing animal and human effigies appear to be singularly limited in their distribution. At Santa Rita seven have been explored in all, eich containing 1 to 49 effigies, some very erudely and roughly made from sun-dried clay, others nicely modeled and painted in various colors. Probably several more of these mounds had been removed by the former owners of the estate to obtain stone for building and road-making purposes, as figurines similar to those taken from the excavated mounds were found in the possession of coolie laborers working on the estate, which they said they had found from time to time when digging for stone. The effigies comprise figures of men, alligators, turtles, quashes, lizards, birds, sharks, 
and snakes, together with two-headed dragons and other mythologic animals. Similar mounds containing animal effigies have been found at Douglas, about 18 miles southwest of Santa Rita; at Bacalar, 25 miles northwest; at Corozal, less than a mile south; and near San Antonio, about 9 miles north of it. In each of these localities only a single effigy was found, the workmanship of which resembled so closely that of the Santa Rita specimens that it wou!d be difficult to decide from which locality they had come.

So far as it has been possible to ascertain, no similar human and animal effigies have been previously discovered in this section of the Maya area. The significance of these figurines appears to be somewhat obscure. They are not invariably found associated with human remains, though this may be owing to the fact that the bones have completely perished through decay or because cremation has been practiced. They show no signs of use or wear and were evidently made only to be buried. The hollow specimens frequently contain one or more beads of red shell, greenstone, or clay in their interiors, while in most cases they have been found associated with fragments of pottery incense burners, which in this region seem to have been very commonly mortuary in use. On the whole it secms probable that these figurines were merely votive offerings to the gods, buried with the dead. Some of them may indicate the occupation of the individual with whom they were buried. $A$ priest and warrior from the same mound have been described, whose occupant may have combined the double office, while a small statuette of an old man, with a macapal slung over his shoulders, by a strup pasingr across the forehead (typieal of an Indian laborer of the present c!ay), was found by a coolie digging out stone from a mound at Santal Rita many years agoo.

\section{Mound No. 4}

Mound No. 4 (No. 7 on the plan of the Santa Rita mounds) ${ }^{2}$ has recently been exearated, together with nearly the whole of the earthwork on its south side. The mound was eireular at the base, conical in shape, 57 feet in height, 471 feet in cireumference, and was built of blocks of limestone hedd together by mortar. On the south side of the mound and continuous with it was a cireular carthwork 100 yards in diameter. The walls inclosing the cireular space varied from 10 to 25 feet in height. They were higher towarl the north, where they were continuous with the large mound, and lower toward the south, where an opening 30 foed wide grave acerss to the inclesure. The summit of the mound was trunciated, cireular, and about 20) fort in diameter. It was coreced by a layer of allurial

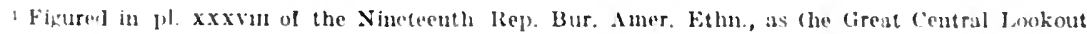
II ound. 
earth 4 inches in thickness, on removing which the following objects were brought to light, lying on the layer immediately subjacent, near the center of the mound: (a) A leaf-shaped spearhead of very light yellow flint, 5 inches in length; (b) a leaf-shaped spearhead of reddish flint, $5 \frac{1}{2}$ inches in length; (c) an eccentrically-shaped flint object (fig. 19, a), $4 \frac{1}{4}$ inches in breadth by $2 \frac{3}{4}$ inches in depth, of light grayish flint, very neatly and carefully chipped; (d) a large, well-made flint arrowhead, deeply grooved on each side of the base, $2 \frac{1}{2}$ inches in length, and of light grayish color (fig. $19, b)$; (e) the broken end of a roughly chipped flint hook or crescent (fig. 19,c). With these flint objects were found a small red-stone bead and a quantity of pieces of broken images, as arms, legs, faces, hands, breastplates, etc., in rough pottery. Bclow the alluvial layer the mound was composed of large blocks of limestone, held together by mortar, giving it the consistency of masonry and rendering digging in it very difficult. At a depth of 6 feet a small oblong chamber was opened, built of rough blocks of limestone, about 8
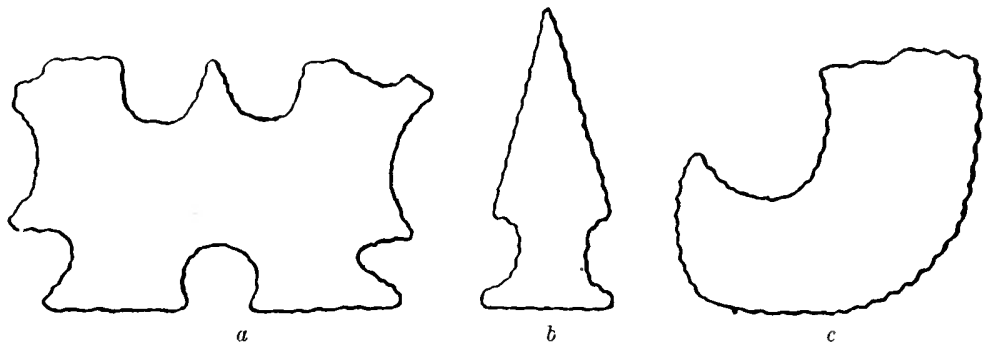

FIg. 19.-Objects from Mound No. 4.

feet by 3 feet, within which were found fragments of human bones, the head pointing to the north. At both head and feet a few rery roughly chipped spearheads were found. $\Lambda$ t a depth of 10 foet another small chamber, 4 feet in length by 2 feet in height and 2 feet in breadth, was opened, also composed of rough blocks of limestone. Within this were four basin-shaped ressels; two, somewhat larger than their fellows, were superimposed upon them (fig. 20). These basins were made of rough pottery, colored yellow, with a broad red stripe round the rim. Each was piereed by a pair of small round holes, 1 inch apart, repeated at equal intervals four times round the circumference, about one-half inch from the margin. The perforations in the upper vase corresponded exactly to those in the lower when they were discovered, suggesting that they had been connected by cords of henequen fiber, $t i-t i$, or some perishable material which had disintegrated. It was considered certain that these ressels would contain a number of the small pottery figures which similar ressels from neighboring mounds had yielded. On removing the cover from the first one, however, it was found to contain nothing 
but a small quantity of impalpable dust. The second contained about an equal quantity of similar lust, together with a small rough opal. The excavation of this mound was continued to a depth of about 18 feet, but nothing further was discovered.

The circular space inclosed within the earthwork was surfaced by a layer varying from 2 feet to 3 feet in thickness, resting on the bedrock, and composed of rubble and powdered marl beaten into a compact mass, covered by two layers of cement, one beneath the other, which formed a smooth level floor over the whole inclosure. A great part of the earthwork and the rubble from the flour of the inclosed space have been removed to repair the Corozal streets. Nothing, however, was found within them with the exception of a few broken flint axheads and spearheads, some hammerstones (which are found practically everywhere), fragments of obsidian knives, and quantities of potsherds. Plate 10 shows a section through the earthwork in process of removal at its western extremity.

The wall is 21 feet 8 inches in height at this point, though only about 17 or 18 feet are shown in the photograph, as the ground was filled up behind the men excavating by a heap of limestone dust 3 or + feet high, left after the stones had been removed. The wall is composed here from the ground up of -(1) a layer of small rubble, 18 inches in thickness, the stones composing which had apparently been picked off the land; (2) a layer of cement, 6 to 8

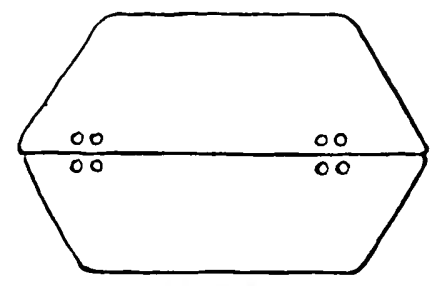

FIG. 20.-Pottery vessels from Slound No. 4. inches in thickness (the upper surface of this laver is continuous with the upper surface of the cement covering the inclosed space, and the two together eridently formed originally one continuous flat, smooth pavement); (3) a layer of large rough blocks of limestone, 8 feet in thickness, built in together with some care, but without the intervention of mortar (these blocks had evidently been quarried out especially for this purpose, as they were quite fresh and showed no signs of weath(oringr); (4) a cement layer 3 feet in thicknesis, composed of alternate thin layers of bluish gray cement and thick layers of yollowish coment, which can be faintly seen in the photocraph. At the point B, plate 10 , were found a cuantity of ashesind smull pieces of charred wood; the litrese stones in the neighborhood wore nlso blackened by the aretion of fire, and ashes were mixed with the lower part of the coment layer, whirh wonld semingly indiente that a larere fire, lasting a considerable period, had been kept up at this point on top of layer c before the coment capping was added. The top lilyer, 8 foet high, is composed of loose, friable mortar with rough blocks of limestone sot in it irregularly and finished with a conical apl. In the 
upper center of plate 10, $b$, may be distinguished a trench, 3 feet in width, which runs through the whole thickness of this layer. Its walls are composed of rough limestone blocks mortared together. The trench was completely filled in with small loose rubble similar to that found in layer $a$.

The high, steep, solidly constructed mounds, the bases of many of which are connected with more or less circular earthworks, were probably lookouts or observation mounds. Most of these mounds terminate in a narrow flattened summit too small to have supported even the smallest temple, while many of them form the centers or nuckei of other groups of mounds. Few contain anything besides the stone, mortar, and earth of which they are constructed, though some of them contain superficial interments. That at Santa Rita is exceptional in that it includes stone-faced cysts. These mounds extend in a more or less regular chain along the coast of Quintana Roo and British Honduras, reaching from the top of Chetumal Bay nearly as far south as Northern River, and extending inland in a southwesterly direction along the courses of the Rio Hondo and Rio Nuevo, though many are situated at a considerable distance from either sea or rivers.

\section{Mound No. 5}

Mound No. 5 (No. 27 on the plan, fig. 14), situated about 200 yards to the southeast of the fortification, was 3 feet in height, 30 feet in diameter, and nearly circular. It was built of blocks of limestone, rubble, limestone dust, and earth. Many of these blocks had evidently been taken from some building, as they were well squared. About the center of the mound, at the ground level, a small cyst was discovered, 3 feet long, 2 feet broad, and 1 foot high, built throughout of rough flags of limestone. Within it were two vases; one, shown in figure $21, a$, is of rough umpainted pottery, $4 \frac{1}{2}$ inches high, with a small earlike projection on each side, each of which is ornamented with an ear plug. Vases with these earlike projections and ear plugs are not uncommon in this area, and are probably highly conventionalized incense burners. The figure of the god outside (which, as will be shown later on, was represented after a time by the face only) has here had every feature and ormament of the face eliminated with the exception of the ears and ear plugs, which would always be unmistakable.

The other, seen in plate 11 , is an egg-shaped vase standing on three short legs. It is decorated outside with a human face and was originally painted white throughout and ornamented with black lines. It has a small opening at the top covered by a triangular stopper. Within this vase were found two small polished beads, one of greenstone, the other of red shell. Throughout the mound were found numerous fragments of incense burners, with the small head of a 


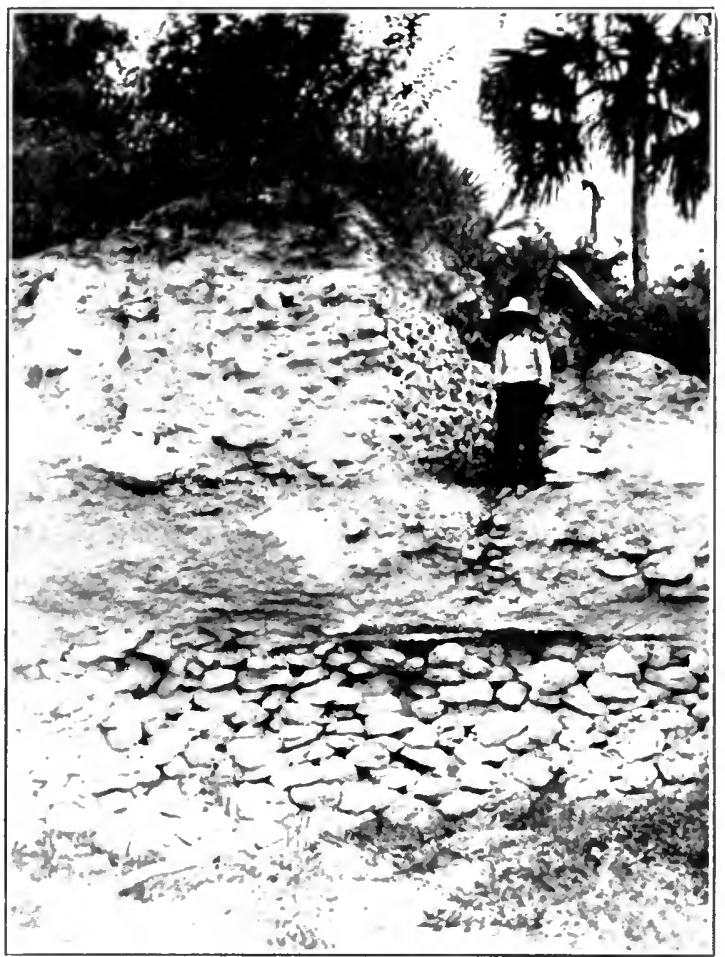

a. SECTION THROUGH EARTHWORK INCLOSING CIRCULAR SPACE, SANTA FITA

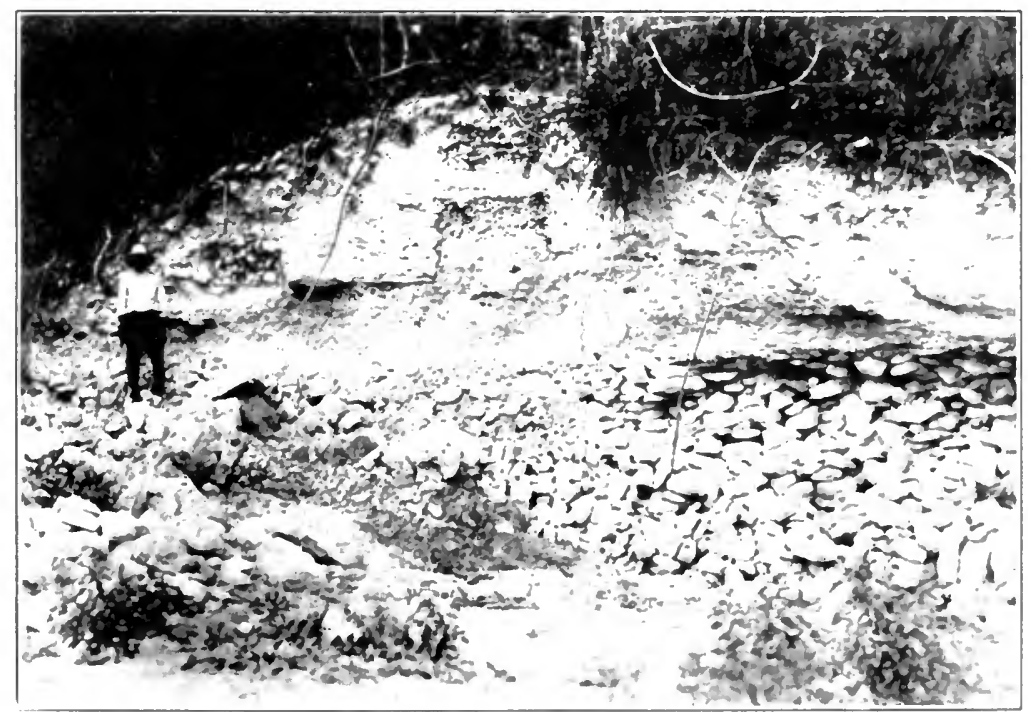




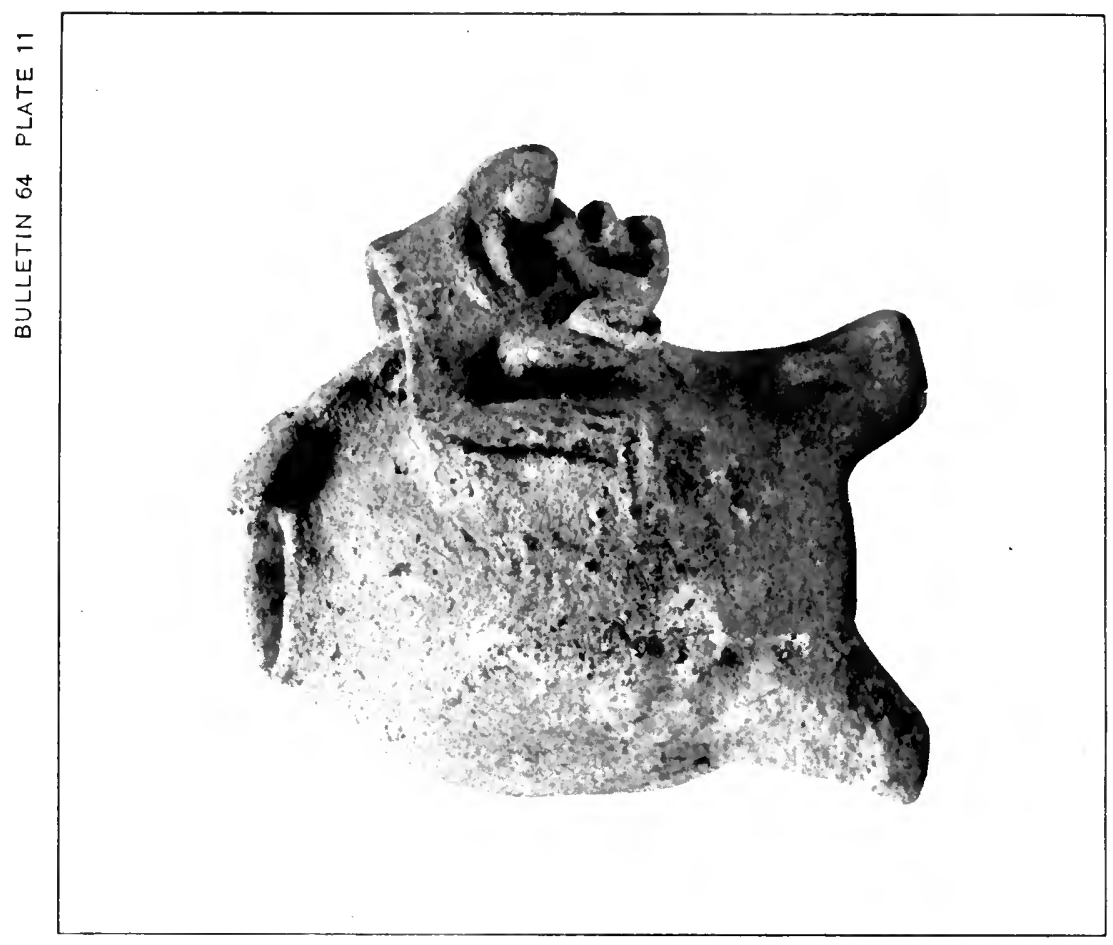

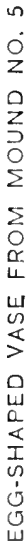

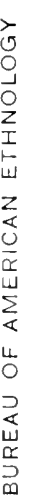

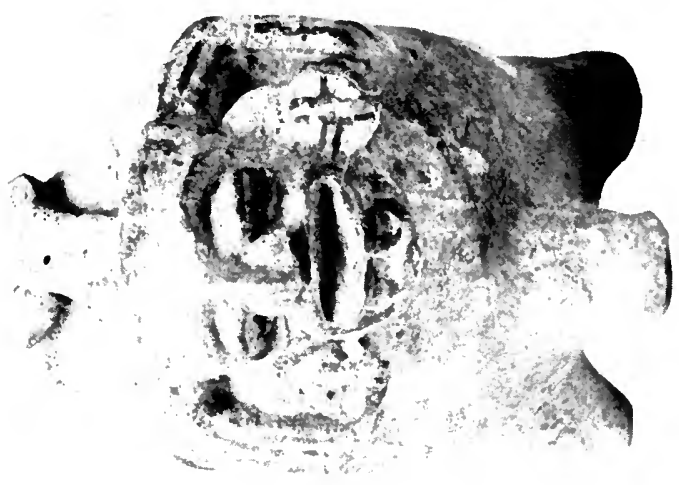


tiger, 2 birds, 5 small beads, 2 malachates, 4 net sinkers, and the ceremonial bar shown in figure $21, c$; all in rough pottery. About 5 feet from the northem edge of the mound were found human bones, representing a single interment, seemingly of a male of middle age. The skull and long bones, which were very brittle, though they hardened on being exposed to the air for a day, were gotten out only in fragments. The molar and premolar teeth are hearily coated with tartar but are not greatly worn down at the crown; the incisors, on the other hand, are rery much worn and in life must have been nearly level with the gum. Marked attrition of the incisors seems to be present in nearly all the teeth of individuals past middle life found in sepulchral mounds throughout this area, which
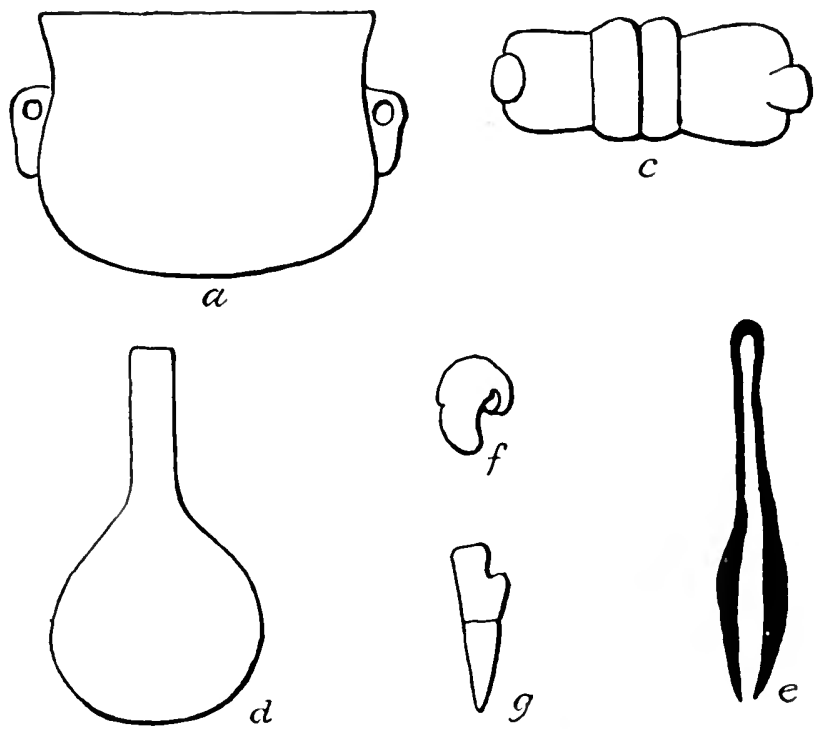

Fir. 2l.-()jects found in Mound No. 5.

is rather remarkable, as the staple diet of the ancient inhabitants must have been nearly identieal with that of the Indians of the present day; that is, maize ground to a fine paste on a stome motate, which of neressity contains a crood deal of grit from the motate, so much so that the modern Maya say that an old man rats two rubling stone's and six rubbers during his life. This gritty nistamal wears down the back teeth of the modern Maya almost to the gum, but does not materially affect the front teeth; yet it is the latter, not the former, which we find affecterl in maxille from the momme. One of the molar teeth from this hurial has had a triangular piece remoxed from its crown (fig 21, $f^{\prime}$ ). Along one edge of the gap left the torth is carious. 
Mingled with the human bones were found: (a) A flat, oblong object, made of finely polished bone, 1 inch broad and one-tenth inch thick. Its original length could not be determined, as the upper part had been broken away. (b) Three beads, one of polished greenstone, two of polished red shell; one of the latter was $1 \frac{1}{3}$ inches long, with two ineomplete perforations passing through it longitudinally. It had probably been intended to form part of a wristlet. (c) Parts of three small obsidian knives which had evidently seen considerable use, as their edges were much chipped. (d) The curious object shown in figure $21, d$, front riew, and $e$, side riew. It is made of copper, and was evidently used as tweezers, either for the removal of hair, for which purpose it would be admirably adapted, as the lower expanded parts of the blades when pressed together come into such close apposition that the smallest and most delicate hair can be remored by means of them $;^{1}$ or for the extraction of small thorns from the skin. Landa mentions the fact that the Maya were in the habit of removing the hairs from their chins and lips, but if this little implement was the only one employed for the purpose the custom ean not have been a very common one in this locality, as no other similar specimen was found in any of the mounds. Passing from north to south through the mound, about 8 feet from its center, were two parallel rows of limestone flags, set perpendicularly, about 18 inches apart. Against the outer of these rows lay a considerable accumulation of animal bones, probably those of the tapir. In the space between the outer row of flags and the elge of the mound were found 10 oblong blocks of limestone, a veraging 18 by 10 inches, the upper surfaces of which were hollowed out to a depth of 3 or 4 inches. These were probably intended as water receptacles for the use of fowls or small animals kept about the home, as precisely similar small stone troughs are made and used by the modern Indians for this purpose. The space between the rows of flags was floored with mortar, but nothing was found within it.

\section{Mound No. 5 A}

Mound No. 5 A (No. 28 on the plan, fig. 14) was situated within a few yards of the opening into the circular earthwork attached to Mound No. 7. It was long and narrow, nowhere exceeding 2 feet in height. It was built throughout of small limestone bowlders, mixed with a large proportion of black earth. The limits of the mound were difficult to define, as the earth of which it was

1 Landa, in mentioning the beardlessness of the rucatecans at the time of the conquest, says it was reported as being hrought about by applying hot cloths to the chirs of the children. This seems improbahle. "No criavan barhas, y clezian que les queinavan los rostros sus madres con paños calientes, siendo nirios, por qtie no les naciessen, y que agora crian barbas aunque muy asperas como cerdas de tocines."1...11.A, op. cit., 1. 114 .

The jure-bluod Indians of the present ray have hut a very scant $y^{*}$ growth of lair on the face and pubes, ant in some cases even the few straggling hairs which they lossess are pulled out. 
built had been washed down and mingled with the surrounding soil to so great an extent that it was almost impossible to determine where one began and the other ended. This mound or ridge has not as yet been completely explored, but in the part which has already been dug down two interments were found. The first was quite superficial, about 1 foot below the surface, near the custern extremity of the ridge. The bones were those of a well-devcloped male, of rather unusual height and muscular development for a Maya Indian; they were in an exceptionally good state of preservation, though not protected from the surrounding earth by cist or burial chamber. Unfortunately, the skull was smashed into small fragments by a careless blow of the pickax before it was realized that a burial existed at the spot. The body appeared to have been buried lying upon the right side, with the legs flexed at the knees and thighs. From one of the incisor teeth a quadranglar piece had been cleanly removed (fig. $21, g$ ). Unfortunately, the tooth in contact with it on the other side could not be found, so that it was impossible to ascertain whether a corresponding picce had been removed from this also. The tooth was much worn at the cutting elge. Landa describes a grinding down of the teeth to a sawlike edge, for ornamental purposes, practiced by the Yucatecans at the time of the conquest, ${ }^{1}$ and it seems probable that this tooth was operated on for a similar purpose.

With the bones were found: (a) An oblong picce of marble-like stone, 2 inches long, $1 \frac{1}{2}$ inches broad, and 1 inch deep, polished on all its surfaces, probably usod for smoothing or burnishing; (b) what appeared to be a piece broken from a rubbing stone which had been squared, and which showed marks on its upper surface indicating that it had been used for giving an edge to stone implement:; (c) fragments of rough unpainted pottery.

The second interment was that of a child 8 to 10 years of age. The site of this burial was within a few feet of the first, at a depth of about a foot below the surface. The bones, which were in a fair state of preservation, were in contact with the earth of which the mound was built. The corpse appeared to have been laid on the side, with the legs drawn up. With the bones were found only a few ornuments broken from pottery incense burners, as ear plugs, small animal heads, and part of a quilted breastplate.

This mound was probably of a much later date than the other mounds described at Santa Rita. It is merely an irregular ridgo huilt of earth and stomes, whilo the earlior mounds just referred to are well defined and constructed of blocks of limestono with rubble, limestone dust, and mortar filling in tho interstices. The bones,

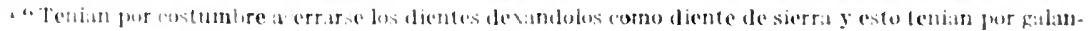

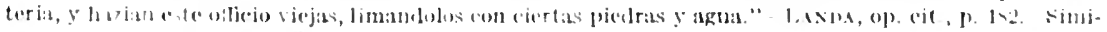
larly filed theth habe been descovered at copan and in caves at Loltun. See Joyce, Mexilas . Archacology, 1. 231. 
though placed under the most unfavorable conditions, having been in direct contact with the damp earth, are in an excellent state of preservation, far better, indeed, than even the best preserved of those in the other mounds where the conditions are decidedly more favorable. The skeletons of children are practically never found in the other mounds, as the bones have long since disappeared completely, while here we find the bones of a child under 12 years of age in a faily good state of preservation. There are a number of these sepulchral ridges at Santa Rita, many of them hardly distinguishahle from the surrounding soil; they are all seemingly of much more recent date than the other mounds, and are probably the work of Maya Indian tribes who flourished long after the conquest.

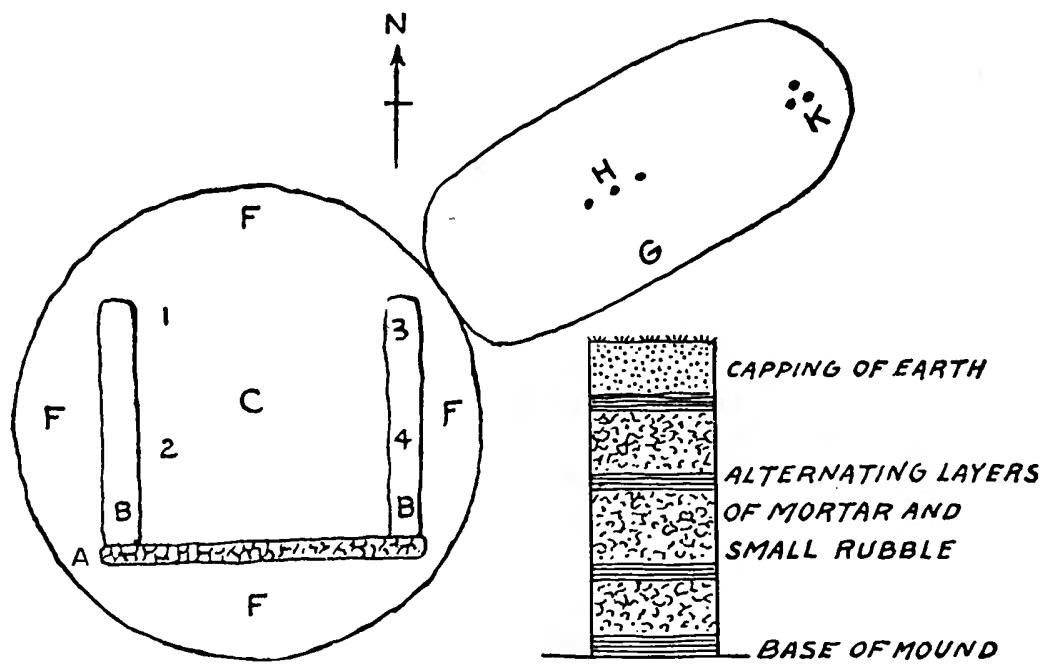

FIG. 22.-Diagram of Mound No. 6.

Mound No. 6

Mound No. 6 was situated near the southwestern boundary of Santa Rita. The mound was nearly circular, with flattened top, 25 yards in diameter, and 10 feet high at its highest point. Toward the southern sicle of the mound was unearthed a wall (fig. 22, A) 2 feet thick, 2 feet high, and about 15 yards long. From the ends of the wall roughly made masses of limestone and mortar (fig. 22, BB) passed almost through the mound, inclosing a rectangular space, $C$. The wall was evidently the remains of an older structure, as it was built of well-squared stones and had been broken down at both the top and sides. The masses of masonry (fig. 22, BB) were 5 to 6 feet thick by about 5 feet high. The space $\mathrm{C}$ was filled with alternating layers of nortar and small rubble. 'The spaces (fig. 22, FFF) at the periphery of tho mound were filled with rubble mixed with earth. 


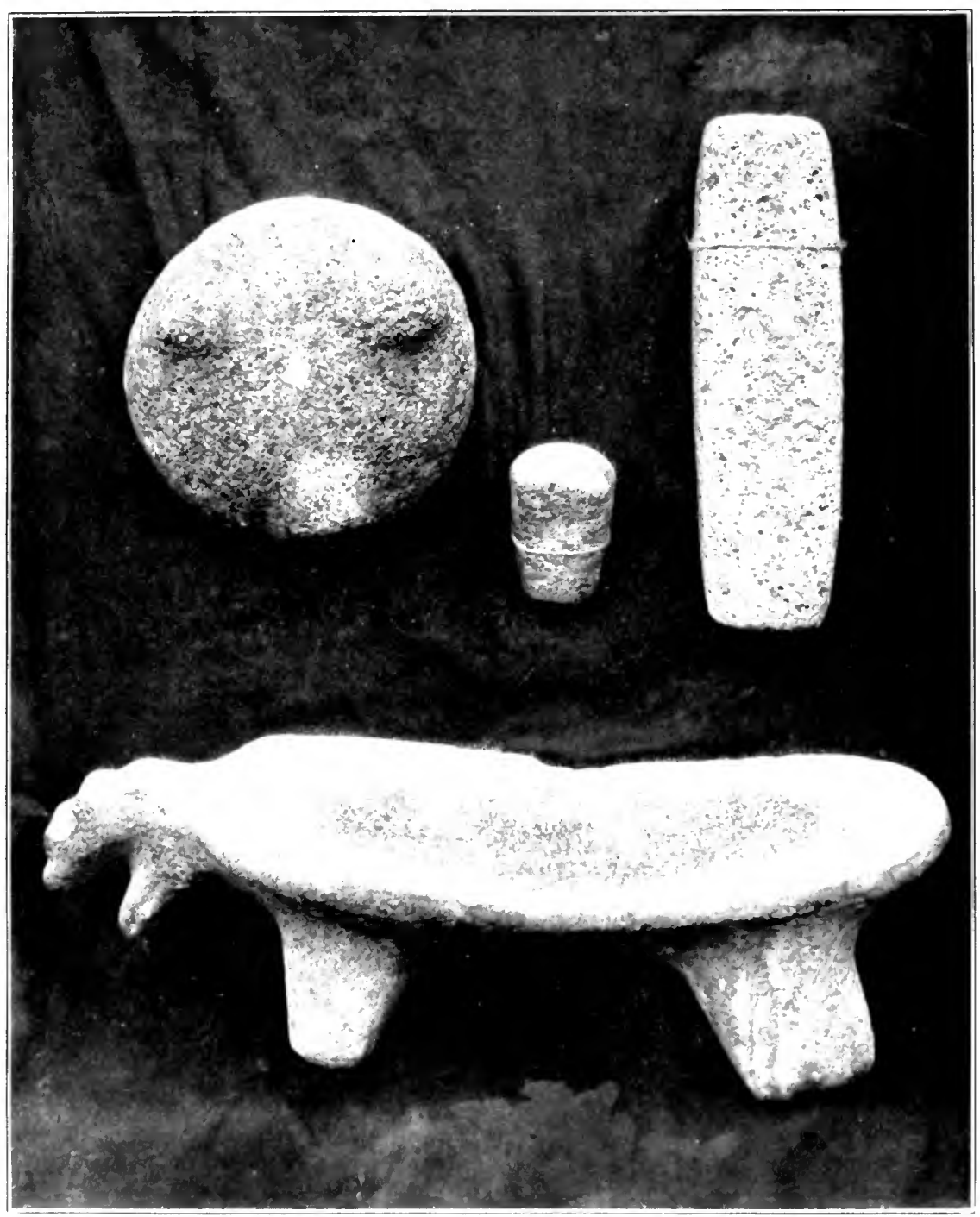




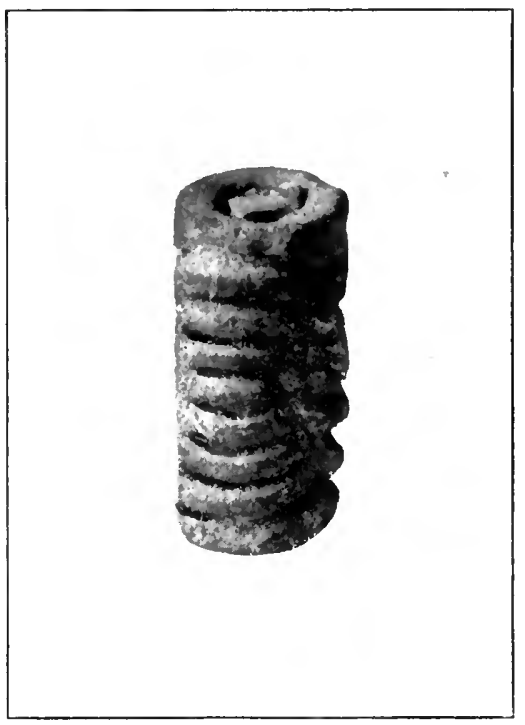

a. SMALL POTTERY SEAL

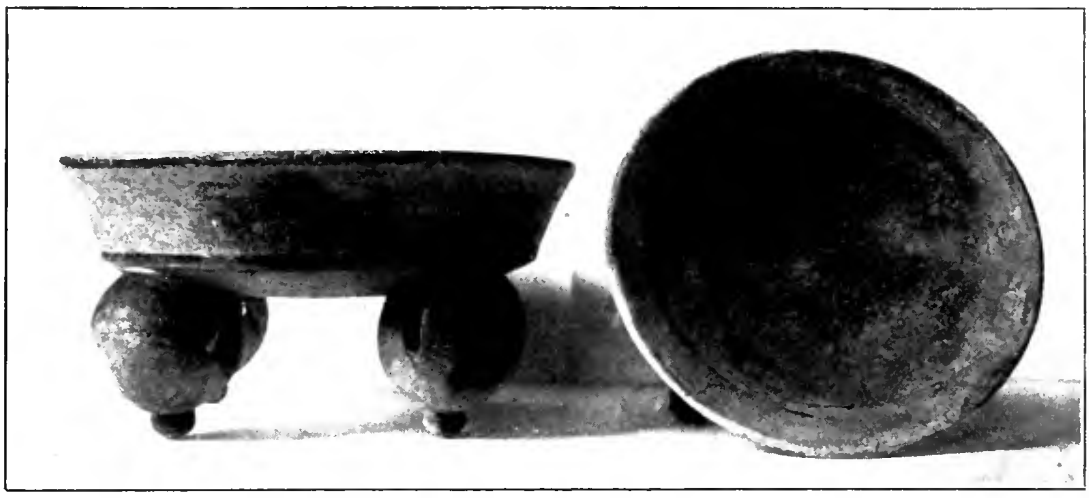

b. BOWL IN WHICH SKULL WAS FOUND

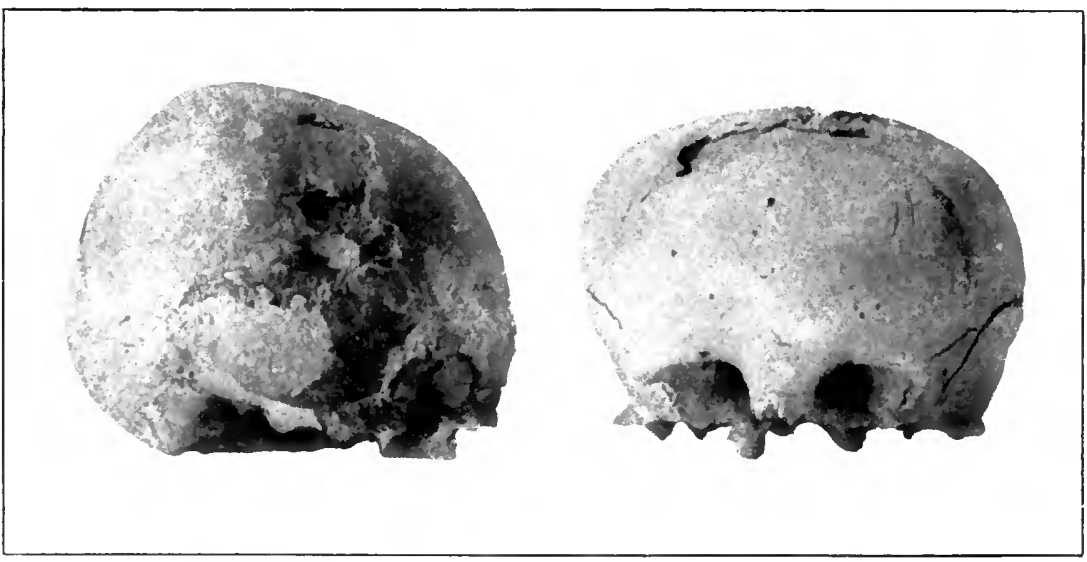

c. SKULL

Length, $15.9 \mathrm{~cm}$; brathth, $1.5 .4 \mathrm{~cm}$; height, $13.3 \mathrm{~cm}$; circumference, $4.9 \mathrm{~cm}$ 
The rubble, whererer found in the mound, contained large quantities of potsherds, together with flint chips and a few hammerstones. In the spaces FFF were found numerous fragments of metates and brazos, with one unbroken specimen of each (pl. 12). At the points marked (fig. 22, 1, 2, 3, 4) four human interments were encountered at a depth of 12 to 18 inches beneath the surface. The bodies had been buried lying on the back, fully extended. The bones were in a very poor state of preservation, and with each interment were found a few flint chips, hammerstones, broken spearheads, obsidian knives, and one or two small, very roughly made, round cooking pots. The whole mound was removed to provide material for the Corozal streets. On reaching the ground level it was found that a series of trenches had been eut through the earth beneath, to the bedrock, and filled in with small rubble. Figure 23 gives a plan of these trenches, which are in the form of two parallelograms, measuring 9 yards by 6 yards, joined by a third of approximately the same area. The trenches varied from 3 to 4 feet in breadth and from $1 \frac{1}{2}$ to $3 \frac{1}{2}$ feet in depth, according to the thickness of the layer of earth over the bedrock. The space marked figure $23, \mathrm{~A}$, contained remains of at least 30 interments; some of these were in small semicircular exeavations made in the surrounding earth from the sides of the trenches; these are shown at figure 23, D; others were made in holes dug in the earth at various points within the space $A$. The bodies buried in the excarations at the sides of the trenches seem to have been crowded in, in a variety of positions, in order to accommodate themselves to the size and shape of the cavity. Most of those in the space $A$ had been buried head downward, the skulls resting in some cases in earthenware bowls, with the back bent, legs flexed, and knees; drawn up against the chin. Nearly all these bones were decayed and friable, and could not be removed without crumbling away. The only exception was the burial marked figure $23, \mathrm{D}^{\prime}$, from which the upper part of the skull was recovered almost entire, though the facial bones and lower jaw were lost. This skull (pl. 13, c) rested in the bowl shown in plate $13, b$, a handsome piece of pottery. standing upon four nearly globular hollow legs, with slits in their sides, and within them small spheres of clay which rattled when the bowl was movel. It is painted yellow and red throughout, and is nicely polished. A great number of objects were found accompanying the bones in the space $A$. These included flint ax heads and spearheads, flint scrapers, and hammerstones, two obsidian spearheads, and fragments of obsidian knives, shell and chy beads, and a small cylindrical pottery seal about 3 inches in length, with a geometrical device in low relief stamped upon it $(p) .13, a)$. The bones of the peceary, curassow, snake, and of somo variety of fish were also found, together with the sholls of 
conches, cockles, snails, and hooties (a large variety of freshwater snail still eaten by the natives). A block of crystalline limestone, 18 inches long by 8 inches high and 12 inches broad, was found in one of the semicircular pits leading from the trench at the upper border of space $\mathrm{A}$, figure 23. It was traversed by 14 longitudinal grooves on its upper surface, which was slightly concave; each groove was $\frac{1}{2}$ inch broad by $\frac{1}{4}$ inch deep, quite smooth, and nearly straight. The stone had seemingly been used as a hone for' giving an edge to small stone implements.
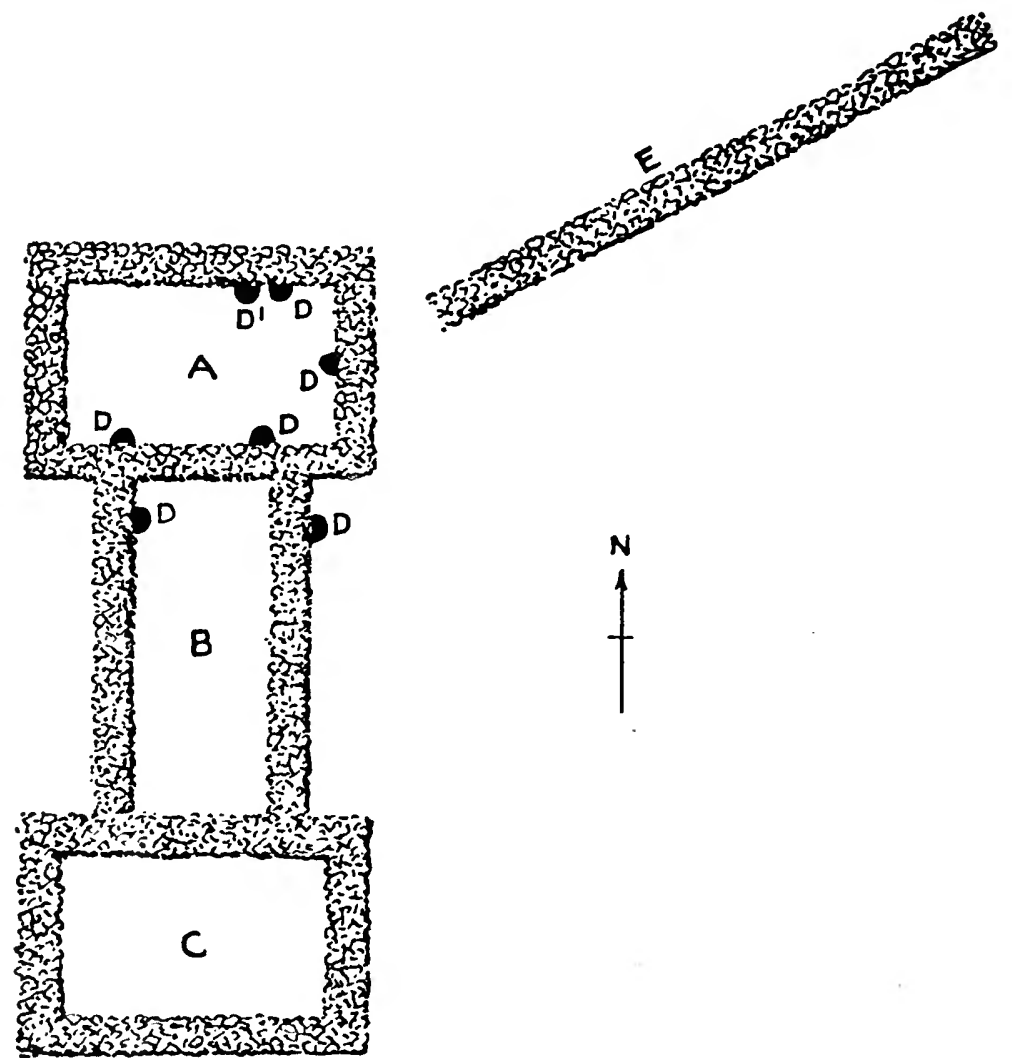

FIG. 23.-Diagram of trenches in Mound No. 6.

Extending out toward the northeast from the main mound was a low structure (fig. 22, G) 4 feet in height and 25 yards in length. It was composed throughout of layers of clay, rubble, and limestone dust, not very clearly separated. Three separate interments were found beneath this mound near its center (fig. 22, H), the bones in all of which were very much decayed. From the first of these the shallow bowl (fig. 24, a), $7 \frac{1}{2}$ inches in diameter by $1 \frac{1}{2}$ inches deep, together with the vase $d, 8$ inches in height, were taken. The rase was of rather fine pottery, painted a uniform dark red throughout. Nothing else was found with this interment. 
From the second grave were taken a bowl exactly similar to that shown in figure 24, $a$, two flat dishes 12 inches in diameter (fig. 24,e), and a small polished bone ring 1 inch in length, seemingly a section from one of the larger long bones of some large animal. The vessel $g, 6$ inches in diameter, was also found with this burial; it is made of fine pottery, painted red, and possesses a curious upturned spout, which bends inward toward the rim of the pot to such an extent that it would be impossible either to drink or pour out the contents therefrom. These curious pots, usually with the spout parallel to the perpendicular axis of the ressel, are quite conmon

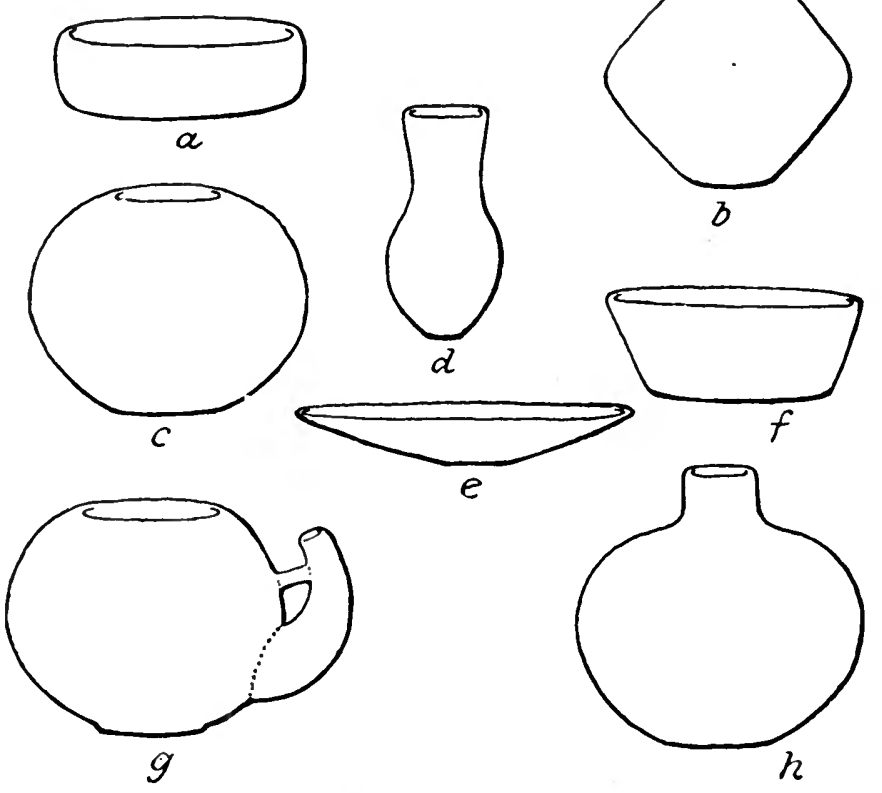

FIG. 24.-Bowls, vases, and dishes found in Mound No. 6.

among Maya pottery from this distriet ; they were supposed to have been used as chocolate pots, but drinking from them must have been a fout of leugerdemain.

From the third grave came two bowls, both almost spherical, the onc 12 inches, the other 6 inches, in diameter (fig. 24, c). At the point $\mathrm{K}$, near the end of the mound $\mathrm{G}$ (figr. 22), three interments were found, very close together, on the ground level; these had evidently bern contained ut one time in a small oval cist, built of rough blocks of limestone, which had now completely caved in. With the bones were found the vases shown in figure $2 t, b, f, h$, of the simme rod-painted pottery as wis found elsewhere in tho nound. Six wollmade bone awls, or lance houds, euch about 6 inches in length, 
together with a heap of the shells of some large bivalve, one of which was polished and perforated for use as an ornament, were also found among these bones. The stones of which the eist had been built, the bones, and the objects accompanying them were so inextricably mixed that it was impossible to tell which objects belonged to each set of bones. Passing through the long axis of this mound was a rubble-filled trench, 3 feet in breatth, dug down to the bedrock,

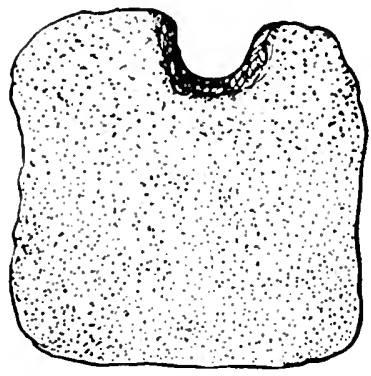

Flag of limestone shown in $\mathrm{D}$, fig. 25. exactly similar in structure to those already described. No interments were found at the sides of this trench, which is shown in figure $23, \mathrm{E}$.

\section{Mound No. 6 A}

Mound No. $6 \Lambda$, another of the group of mounds adjoining the southwesterly boundary of Santa Rita, measured 18 feet by 15 feet at the base, by about 3 feet high at the highest point, and was built throughout of earth, largo blocks of limestone, and limestone dust. The mound rested directly on the limestone formation. Into this, near the center of the mound, an oral exoavation had been made (see C C, fig.

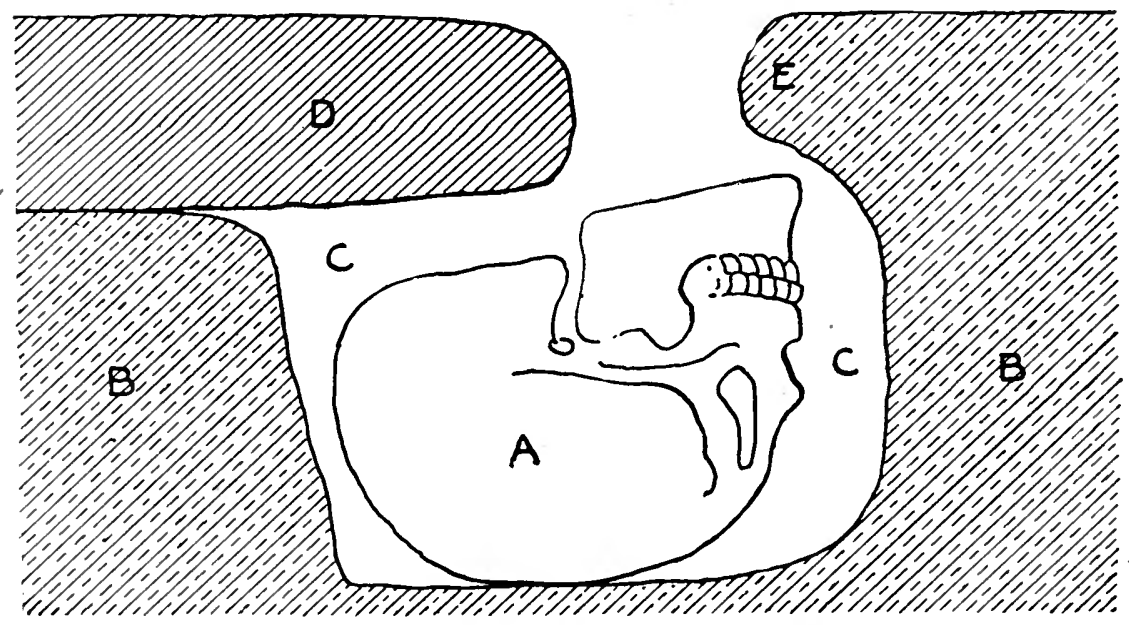

FIG. 25. $-A$, skull; $B$, limestone formation; $C$, excavation; $D$, grooved flag in situ; $E$, projecting lip.

$25)$ about 10 inches in depth, and in size just large enough to contain the skull which was found within it. A ledgelike projection was left at one edge of the excavation (see E, fig. 25), and just beneath this rested the point of the jaw. A large heavy flag of limestone (see D), fig. 25), from which a semicircular segment had been chipped, was placed above the excavation opposite the lip, so that the groore in the stone inclosed the neck and clamped the skull 
tightly down in the little hole which had been made to recoive it. On each side of the skull the femora were found, in a nearly vertical position, condyles downward, and between the femora many fragments of other bones were brought to light, including the tibia, arm bones, and vertebræ. Resting upon the limestone flag which eovered the skull lay a large, rudely made chert hammerstone, 8 inches long by 4 inches broad, which had probably been used in chipping out the semicircular groove to fit the neck. Near the center of this mound, 2 fect below the surface, two very noatly made flint hammerstones were found. 'The dimensions of this skull were: Length, $14.22 \mathrm{~cm}$.; breadth, $16.76 \mathrm{~cm}$; cireumference, $48.26 \mathrm{~cm}$; cephalic index, 123. The base of the skull was so mueh clamaged that the height could not be ascertained. The extreme breadth in comparison with the length, giving it a remarkably brachicephalio appearance, was possibly, to some extent at least, the result of post-mortem compression from before backward within the little cavity which contained it.

\section{Mouxd No. 7}

Mound No. 7, situated very close to No. $6 \mathrm{~A}$, was oval in shape, measuring 30 yards by 10 yards at the hase, and 8 feet high along the summit. It was built throughout of large blocks of limestone, limestone dust, and a small proportion of earth. It rested upon the natural limestone formation, into which, near the western end of the mound, a shallow oval pit 18 inches in length by 10 inches in depth had been dug. In this was found a somewhat imperfect skull, resting with the foramen magnum uppermost. The other bones, which were distributed irregularly around the hole, were in a poor state of preservation. Upon one side of the skull lay a small shallow bowl, with four hollow legs, each containing a pellet of dry clay loose in its interior; and upon the other side a small three-legged vase. Both of these were of rather crude pottery, painted dark-red throughout and polished. Two other excavations similar to this were found in the limestone beneath this mound, each containing fragments of a skull in a very advanced state of decay, surrounded by fragments of the other bones. No additional pottery or other objects were found beside them. The two mounds last described are the only one's in which this peculiar method of interment appears to have been employed. The procedure seems to have been somewhat as follows: First, the earth capping was removed from the limestone rock, over the area to be oceupied by the mound; next, shallow oval pits were due in the rock into which the skulls wore wedged; eath body was bent, and the thights wore flexed on the ablomen, so that the knees touched the rock on eanch side of the head; finally, the momol was built up of linestone dust, arth, and blocks of limestone around the body, in this position. 


\section{Mound No. 8}

Mound No. 8, situated very close to Mound No. 7, was roughly circular, 36 feet in diameter and 4 feet high on its flattened top. It was built throughout of earth, limestone dust, and blocks of limestone. Projecting from the western edge of the mound was a large, roughly hewn block of limestone, 3 feet by 4 feet, and 8 inches in thickness. Ruming through the center of the mound from east to west were two parallel rows of limestone flags, 2 feet apart, projecting $1 \mathrm{~s}$ inches from the limestone rock upon which the mound was orected and in which they were embedded. Near the center of the mound, between the rows of limestone flags and resting on the earth, coverea only with limestone dust, was found a single interment. The sku!l is shown in plate 14. Its dimensions are: Length, $17.01 \mathrm{~cm}$; brearth, $16.51 \mathrm{~cm}$; height, $10.68 \mathrm{~cm}$; circumference, $51.30 \mathrm{~cm}$; cephalic index, 97. The body, which was stretched at full lengt;, had probably been laid face downward, as the bones of the forearms, also shown in plate 14, were found beneath the skull. With the

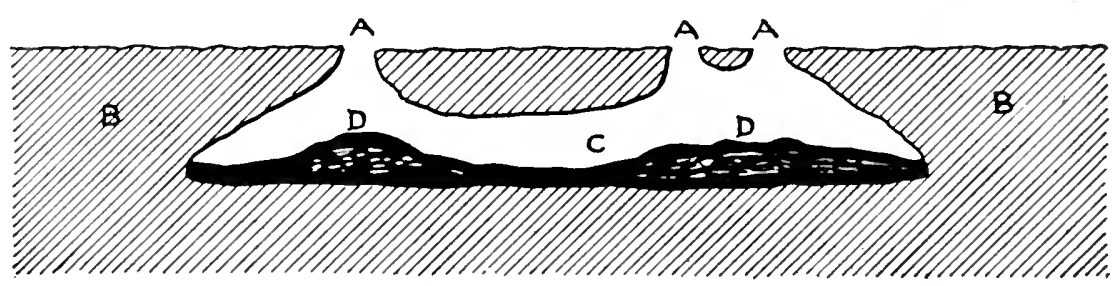

FIG. 26.-Circular openings leading into natural carity.

bones of the hands were found four copper rings, considerably oxidized; three were plain narrow bands, while the fourth was a broad flat band decorated with incised double volutes. Some of the phalanges were colored a bright-greenish tinge, from contact with the rings. Three of the rings and three phalanges are shown in plate 14. These bones were all in a remarkably good state of preservation, probably owing to the fact that they were completely surrounded by fine limestone dust.

Within a fow yards of this mound was the opening of a small chultun, with steps leading to the interior. It was oval in shape, 15 feet long, and at one time had been covered with plaster, which had nearly all peeled off. The floor was covered with earth, of which there was a pyramidal heap under the opening. Nothing was found in this chultun except great quantities of fragments of large, rough earthenware water vessols.

Ahout 300 yards to the east of the mound three circular openings were found (see $A \mathrm{~L}$, fig. 26) leading into a largo irregular natural cavity (see C, fig. 26) formed in the limostone (see BB, fig. 26). Each of 


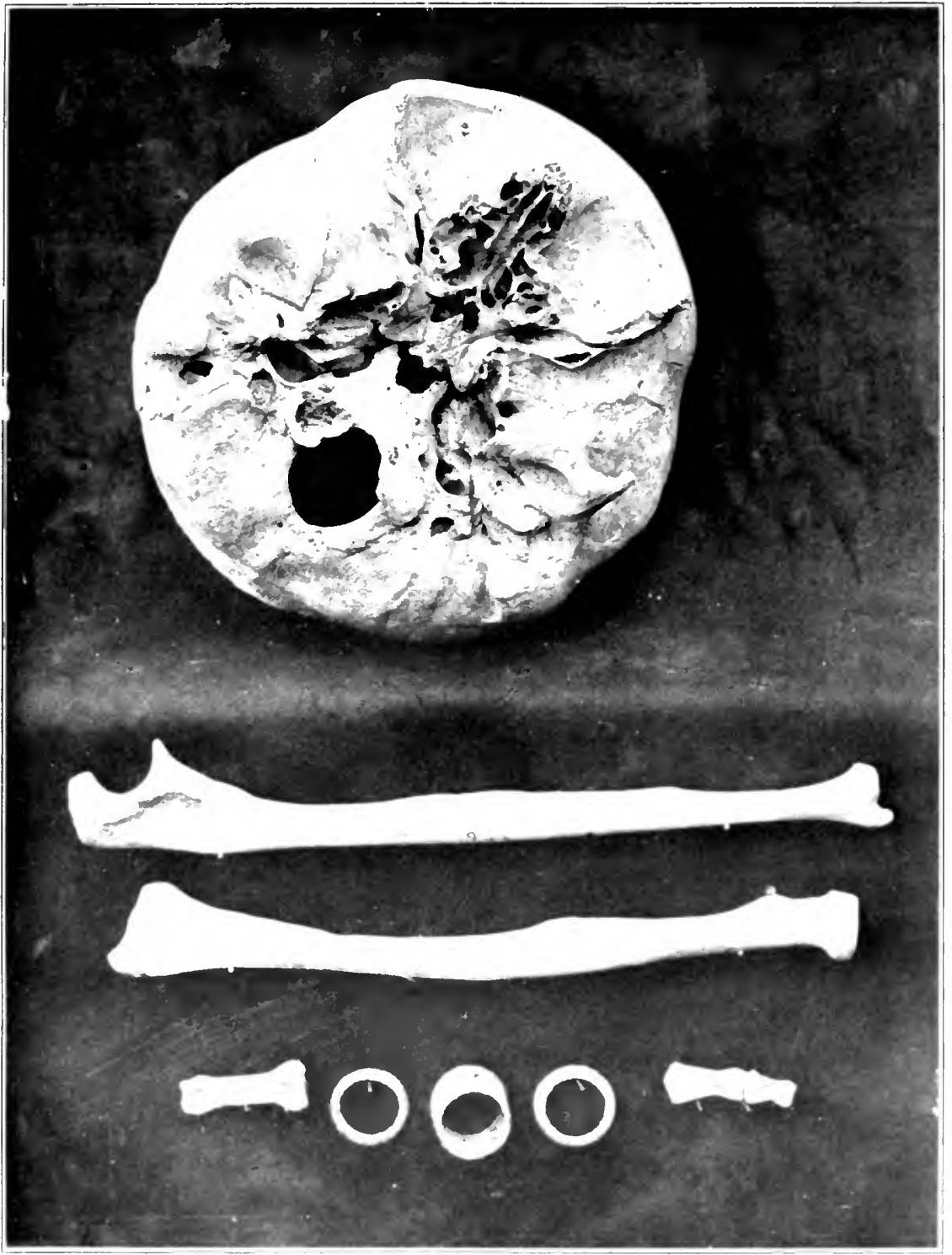



these openings was about 2 feet in diameter, and close to one of them a circular slab of stone, 6 inches in thickness, and of about the same diamoter as the opening, was found, which had probably been used as a cover for the latter. This chultun, unlike the first one, was of purely natural formation; the walls, which wero rough and irregular, showed no signs of tool marks. The chamber varied in height from 8 to 9 foet benoath the openings, where it was highest, to 2 to 3 feet at the sides. There was a considerable accumulation of earth upon the floor (see DD, fig. 26), which had evidently fallen and been blown in, as it was collected in two heaps beneath tho openings. Thero were no stono steps leading down into this chultun, and access must havo been gained to the interior by moans of wooden ladders, which had long since disappeared. Numbers of potsherds, shells, pieces of charcoal, chy beads, and fragments of flint and obsictian implements wero found upon the floor. Several skeletons of small mammals were also found among the earth, but these creatures had probably fallen in after the chultun ceased to bo used, and had been unable to get out.

At a distance of less than half a mile from the last-mentioned chultun another was discovered under somewhat curious eircumstances. A large flat mound was completely removed for the sake of the stone and limestone dust which it contained, to be used in repairing the Corozal streets. About the eenter of the mound, at the ground level, a heavy circular flag of limestone, 2 feet 4 inches in diameter, was brought to light. On removing this it was found to cover a round woll-like opening, which expanded below into a smatl chultun, 1.2 feet long by 9 feet in greatest diameter. Tho chamber was egrershaped and showed no signs of having crer been stucco-covered. From the opening a short flight of steps, cut in the rock, led to the bottom of the chultun. Nothing was found in this chultun with the execption of two small bowls of rather conrse earthenware, painted red and polished; one almost globular in shape, 6 inches in diameter; the other circular, flat-bottomed, $3 \frac{1}{2}$ inches in height. The mound which covered this chultun appeared to have been one of the commonest kind of burial mounds. At its summit fragments of a rude circular carthenware pot were found, and near its eenter fragrments of human bones, together with three flint hammerstones and twosmall round resicels, one of light yellow, the other of yellowish-red, pottery.

One of the most remarkable of the cludtuns found in this area is situated at San Andres, within a mile of the village of Corozal. It was areddentally fommd by some coolies in digging marl, and at, unfortumately, the entire roof of the larger chamber and a comiderable part of that of the smatler had cared in, it was impossible to iosot $-15-$ Bull. 6 t- 6 
discover how it had been entered from outside, as no trace of steps remained. A ground plan of this chultun is shown in figure 27. The small chamber, $A$, is 8 feet long, 7 feet broad, and 5 feet 6 inches high in the eenter; it is cut out of solicl rock. The large chamber (C) is 15 feet in diameter, but as nearly the entire roof has fallen in, it is impossible to estimate its exact height. The ehambers are partially separated by a wall (B) built of rough blocks of stone and tough mortar, which has been partly broken down. In the sicle of the small chamber, opposite the wall, are three oblong shafts $(\mathrm{D}, \mathrm{D}, \mathrm{D}$, fig. 27) cut into the rock, by the side of the chamber wall, which

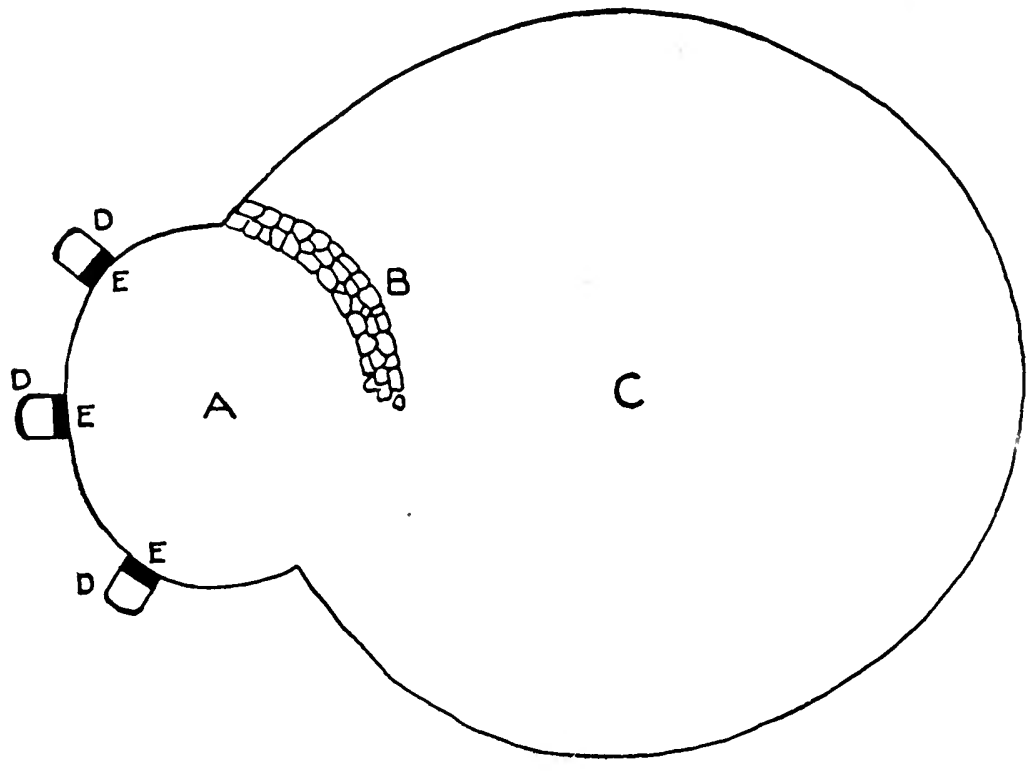

FIG. 27.--Ground plan of chultun.

is here nearly perpendicular. Each of these is about 1 foot in depth by 8 to 9 inches in brealth, and is separated from the chamber by a single row of bricks (E, E, E, fig. 27) mortared together, reaching from the roof to the floor, so that there is no communication between the shafts and the chamber. Each shaft opened originally on the surface of the ground, but the openings lad become blocked by regetable refuse from the surrounding bush. The bricks which fill in one side of each shaft are of two kinds. The first, by f:ar the more numerous, are made of sun-dried clay, yellowish in color, and very friable: they contain considerable powdered marl. They measure $s$ by $+2 y-2$ inches. The bricks of the second kind also are made of clay, mixed with many pebbles; they have been fired, are of a reddish color, far harder and tougher than the first variety; they measure 8 by 4 by $2+$ inches. Nothing was found in either chamber except a few potsherds of various kinds. 
These underground chambers, or chultuns, seem to be fairly common throughout Yucatan. Considerable doubt exists as to the uses to which they were put. ${ }^{1}$ It seems probable that those the walls of which were plastered with an impervious cement lining were intended as water receptacles, since they could easily have been filled by drainage from the thatched roofs of buildings in the vicinity, which have long since completely disappeared. Though the southern part of Yucatan, unlike the northern, is fairly well watered, plastered chultuns are not infrequently found there, but always situated at considerable distances from a good permanent water supply, as a lagoon or river. The uncemented chultuns would not hold water, and had probably been used as storehouses for corn and other provisions. Some of these chambers were undoubtedly used as burial places, as one at Platon, on the Old River, ${ }^{2}$ was covered by a burial mound, and itsclf cont ained human bones; but it is possible that their use for this purpose may have been secondary only. The San Andres chultun is somewhat puzzling, as it was certainly not a reservoir for water, nor were any traces of human burial found within it. It had probably been used as a storehouse for food, though it is difficult to understand the object of the oblong shafts, leading into the open air, found at the side of the smaller chamber, as they must have been quite useless for ventilating purposes, not having any opening into the chamber itself through which the air might circulate.

\section{Mouni) No. 9}

Mound No. 9, situated close to the chultun, with three openings, was oval in shape with flattened summit, 44 foet in breadth, 66 fort in length, and 14 feet high at its highest point. On removing the summit of the mound to a depth of about 4 fect the floor of a building, with parts of the walls, was exposed. The cap of the mound, eovering the ruins of the building, was composed of blocks of marl, clay, rubble, and limestone. The lower part of the mound, upon which the building stood, was eonstructed of large blocks of limestone mortared together, forming a solid block of masonry. The building was in a very ruinous condition; as much of its ground plan as could be

1 Tozzer, in commenting on these chultuns at Nakum, says: "There is widently no close connection, as in Yucatan, het ween the water suphly and these underground rooms. In faw they are frepuently found near sites where there is an ahundant supply of water throughout the year. In almost no case do we find any drainage Into them. They are usually found on grenund slightly higher than that of the surrouneling country. In this respect they differ from those in Yucatan. Another point agsinst their tive as storiso for water is shown in the lact that in several the rock from which they are excavated is porous, and the walls do not seem in all cases to have been covered with an impervions layer of plaster. That they were used in some cases lor the storage of maize und ot her foods is possilble, as they are gencrally dry and would le suitable for suwh a purpose. That some were used for burial plates is very probable." - Tozzen, I l'reliminary Stuly" of the Prehistoric Ruins of Nakum, liuttemala, p. 191.

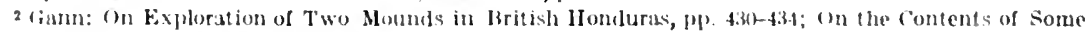
Ancient Mounds in Central Amerin, pp. 304-317. 
traced is shown in figure 2S. The walls, $\Lambda, \Lambda, \Lambda$, are 3 feet 4 inches in thickness. Such parts as remain standing are built of well-squared stones held together by mortar (see fig. 30). They are corered with

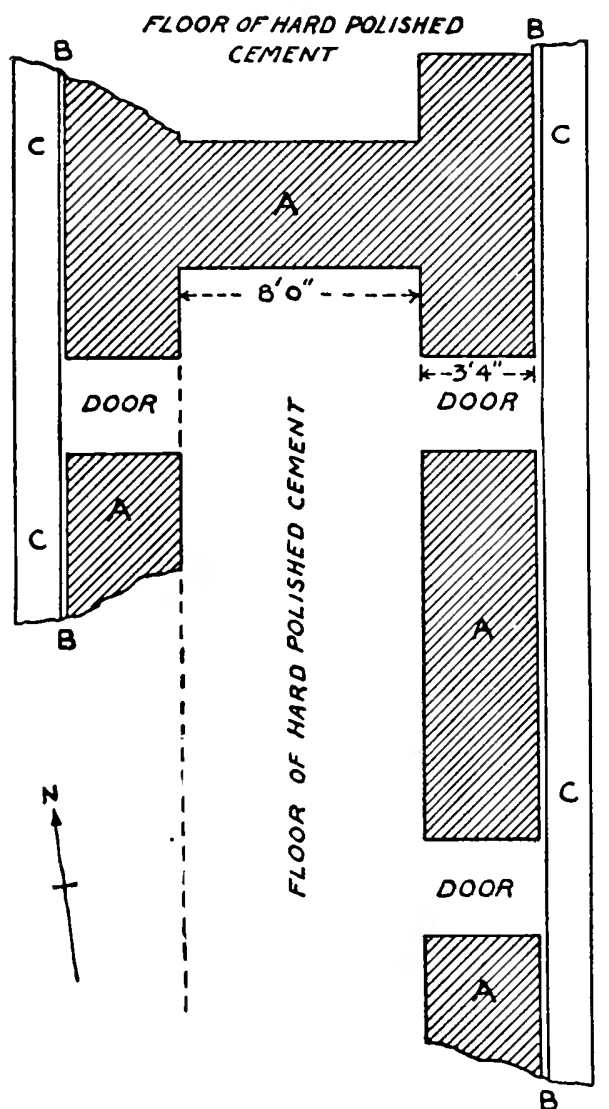

FIG. 28.-Ground plan of MIound No. 9.

stucco inside, which is continuous with the cement flooring of the rooms; outside they were also covered with stucco above the water table(B,figs. 28 and 29) but nearly all of thishad been broken away. The water table, which projects 3 inches from the wall, is 12 inches deep; it is built of well-squared stones not eovered with stuceo, and is continuous below (figs. 29 and 30 ) with $C$, a layer of hard eement 18 inches broad, which apparently ran completely round the building, and possibly acted as a drain to carry off the water after heavy tropical showers. The main room was 8 feet in breadth and had probably been about 30 feet in length; with four doors opening into it, two on each side. This was floored with very hard, smooth, polished cement, which even now is in an excellent state of preservation; this flooring is continuous through the doorways with the top of the water table, with which it is on the same level. Nothing was found in excarating this mound, with the exception of a fragment of a conch-shell trumpet, a piece of an obsidian knife, numerous potsherds, and half of a flint paint grinder, with traces of green paint still adherent to it. All of these objects were found on the floor of the main room.

Mounds erected over the ruins of buildings are extremely common all through this part

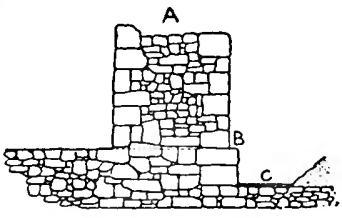

FIG. 29.-Wall construction of Mound No. 9. of the Maya area; some are very large, covering buildings which had been placed on lofty stone pyramids; some are very small, as when they cover buildings of a single small room, built almost 
on the ground level. All the buildings are in ruins, all are raised more or less on stone platforms above the ground level, and all show traces of having been corered with stuceo, both internally and externally. In some cases this stucco is very beautifully decorated in colored devices, as in the mound already described at Santa Rita; ${ }^{1}$ in others the stucco is molded in various designs and ornaments, which may or may not be colored, as in the mound at Pueblo Nuero on the Rio Nuevo, presently to be described. Most of these mounds contain nothing except the building which they cover, but some had

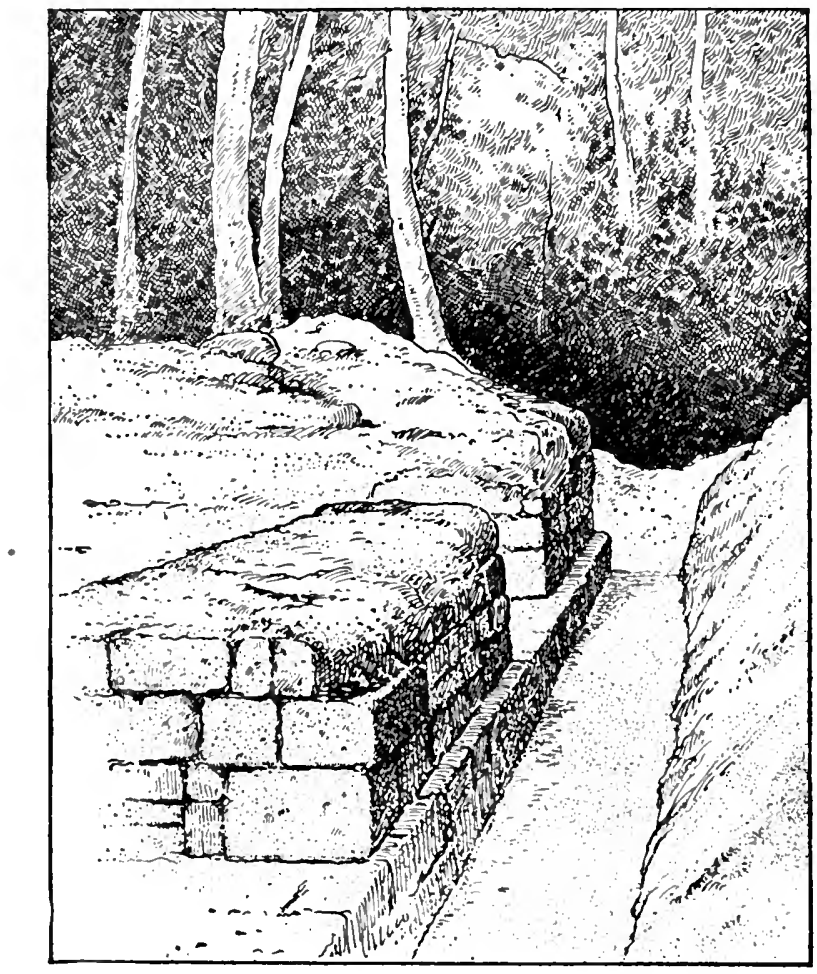

FIG. 30. -Detials of Nound Nu. 9.

becn used as burial places, the interments evidently having taken place after the building had boen covered in, as they are found irregularly distributed through the loose superstrueture which forms the cap of the mound, quite close to the surface. ${ }^{2}$

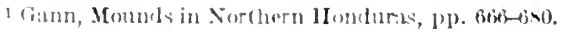

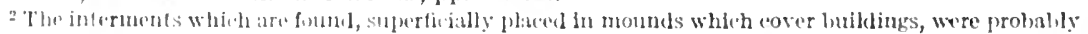

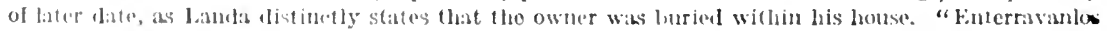

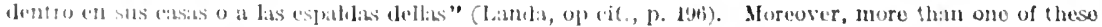
superlial internents are found in monts covering huillings, and, lastly, human remains havo beed fomith leneat h the floors of ruined holses, where one wuld naturally expect to fund thetn.
} 


\section{Mound No. 10}

Vague reports had been in circulation for some years as to the existence of a mound ciose to the headwaters of the Rio Hondo, where the Indians still practiced to some extent their ancient religion. It was said that the mound contained a stone chamber in which stood on a stone pedestal a life-sized image, painted in various colors, and that around the walls of the chamber were niches in which rested life-sized stone turtles, also painted; furthermore, that the bush Indians of the neighborhood were in the habit of coming to the mound for the purpose of burning incense before the idol.

The mound was found situated quite close to the bank of the Rio IIondo, buried in the bush which covers this part of Yucatan. It was 80 feet in height, 350 feet in circumference, conical in shape, and completely covered by high bush continuous with that of the surrounding forest. After elearing the underbrush from the mound an opening 3 feet square was discovered about 17 feet from the summit of the mound on its northern aspect, the walls of which were faced with cut stone. From this opening a low passage led to a small stone-faced chamber 8 feet high, 6 foet broad, and 10 feet long, the floor of which was composed of earth and lime well beaten down to form a hard, smooth surface. Projecting from the walls were eignt small stono brackets, upon which nothing was found. No trace whatever was seen of a painted image or of turtles. The walls and ceiling of the room, especially the latter, were considerably blackened by smoke, possibly caused by burning incense.

Excavation was commenced at once in the floor of the chamber. At a depth of 8 inches the hard floor gave place to soft brown sand, which was continuous to a depth of 2 feet, where several small deposits or pockets of lime were found inclosed within it, each of which contained a number of obsidian knives and small cores. The knives were deoply indented on each side of the hase, as if to facilitate hafting. The cores, of which 20 were found, were slender and varied from 1 to 3 inches in length. On cligging down through an additional 18 inches of the brown sand a layer of lime was exposed about 18 inches in thickness, filling the entire lumen of the chamber, in which were found irregularly scattered 60 cruciform objects, finely chipped in obsidian, each from 3 to 4 inches in length (fig. 31,a). These would have served as either arrowheads or small jarelin heads, or possibly were intended. for coremonial purposes only. With them were a single pottery vase and two small triangular javelin heads of obsidian. The rase (fig. $31, b$ ) was circular in shape, 6 inches in diameter, with a long piglike face protruding from one side. It was made of dark-brownish pottery, painted red and finely polished externally. It was filled with small mussel-like bivalve shells embedded in lime. A number of these 
shells were found also closely adjacent to the vase in the lime which surrounded it. Beneath the layer of lime lay a layer of brown sand, 3 feet thick, in which absolutely nothing was found. Below this appeared another layer of lime, mixed with sand, 4 feet thick, near the bottom of which were found 40 human skulls, neatly disposed in rows. 'These, when first uncovered, seemed to be in a moderately good state of preservation, but when removed from their bed of lime and sand they crumbled so easily that it was found impossible to preserve them. The skulls were all placed in the same horizontal plane, each one nearly in contact with its neighbor. No other bones were found with them, or in fact in any other part of this mound, with the exception of two small oblong objects of bone, about 2 inches in length, each still bearing traces of paint, which were discovered among the skulls. These skulls would seem to have been either the result of secondary interments or the remains of sacrificial victims whose bodies were either eaten or buried elsewhere. In favor of the first theory is the fact that

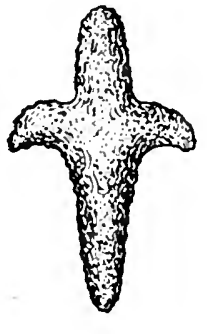

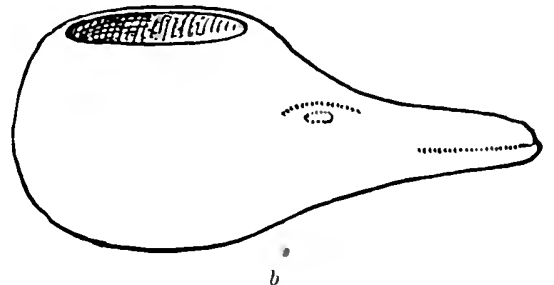

b

Fig. 31.-Obsidian olject and pottery vase from Mound No. 10.

the Maya did not practice luman sacrifice to anything like the same extent that their neighbors, the Aztees, did, and sliughter involving forty-odd victims must have been practically unknown among them. Furthermore, in one or two instances small shallow stone-lined graves, covored with large slabs of stone, have been found at and around the bases of large mounds, and it seems quite possible that these graves may have held the bodies of distinguished dead unt il their skulls were in a fit condition to be removed to the monnd or until a sufficient number had arecumulated to make it worth while opening the chamber for their reception. In faror of the second theory is the fact that, judgring by what could be seene of the tereth and lower jaws, all the skulls were of individuals in the prime of lifo, no jaws of very young or of rery old individunls being discovered. lummerliately beneath the skulls wore unearthed 12 objects of chert fashoned with great eare. Soven of these worespentheuds, the other fivo

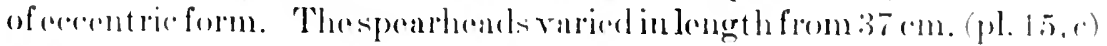
to $29 \mathrm{~cm}$. (pl. 15, $f$ ); the $y$ were very well made, some from gray others 
from brownish-yellow, chert. The eccentric flints comprised: (a) An animal form, possibly meant to represent a bush rabbit, $30 \mathrm{~cm}$. in lengtli from the forehead to the tip of the tail (pl. 15,a); (b) an animal form, evidently meant to represent a turtle or tortoise, 28 cm. in length from the head to the tip of the tail (pl. 15, g); (c) a halberd-shaped implement (pl. 15, $b$ ), exquisitely chipped from lightocher-colored chert, $44 \mathrm{~cm}$. in its greatest length by $19 \mathrm{~cm}$. in breadth across the widest part of the head. This implement is furnished with two sharp-pointed cutting projections in front, separated by a groove; at tho back is a larger triangular sharp projection. The whole implement is well balanced, for use in the hand, by a bulging or thickening of its body between these three projections; (d) an implement chipped from yollowish chert, $44 \mathrm{~cm}$. in length, serrated on each side, pointed at one end and rounded at the other (pl. 15, d); (e) a crescentic implement, chipped from yellowish chert, $26 \mathrm{~cm}$. in its greatest length, $17 \frac{1}{2} \mathrm{~cm}$. across the widest part of the crescent. From the convexity of the crescent project three spines, the central one long and serrated, the lateral ones merely pointed knobs. This object is more crudely chipped and less symmetrical than any of the others (pl. 15,e).

These eccentrically shaped flint and chert objects seem to be limited in their distribution to that part of the Maya area comprised in southern Yucatan, eastern Guatemala, and most of the colony of British Ifonduras. The earliest known specimens are probably those now preserved in the Salisbury Museum, England, which have been thus described:

Imong the numerots stone weapons and implements which have been discovered, and serve to illustrate the primitive arts of the New World, three remarkable relics from the Bay of IIonduras, in South America, are deserving of special attention. They were found about the year 1794, with other examples, in a cave between two and three miles inland. * * * One is a serrated weapon, pointed at both ends, measuring $161 \frac{1}{2}$ inches long. [This object is al most exactly similar to plate $15, d$, except that the latter is pointed at one end only, the opposite one being rounded.] Another is in the form of a crescent, with projecting points. It measures 17 inches in its greatest length, and it is conjectured may have served as a weapon of paradc, like the state partisan or halbert of later times. The third, which is imperfect, has prohably resembled the previuus one in general form. ${ }^{1}$

The second of these implements very closely resembles that shown in plate 15 , e, the Salisbury specimen being somewhat larger, more symmetrical, and more carefully chipped.

About 3 foct beneath these flint objects, embedded in the sand which filled this part of the chamber, were discovered 20 cruciform obsidian alrowheads or javelin heads, similar to that shown in figure $31, a ; 40$ small obsidian cores; 2 obsidian arrowheads, of the shape shown in figure $32 ; 12$ well-made obsidian knives, grooved on each

1 From Wilson, 1)anicl, J'rehistoric Man, vol. I, pp. 214-15, Cambridge and London, 1962; quoted by Stevens, Edward T, in Flint Chips. 


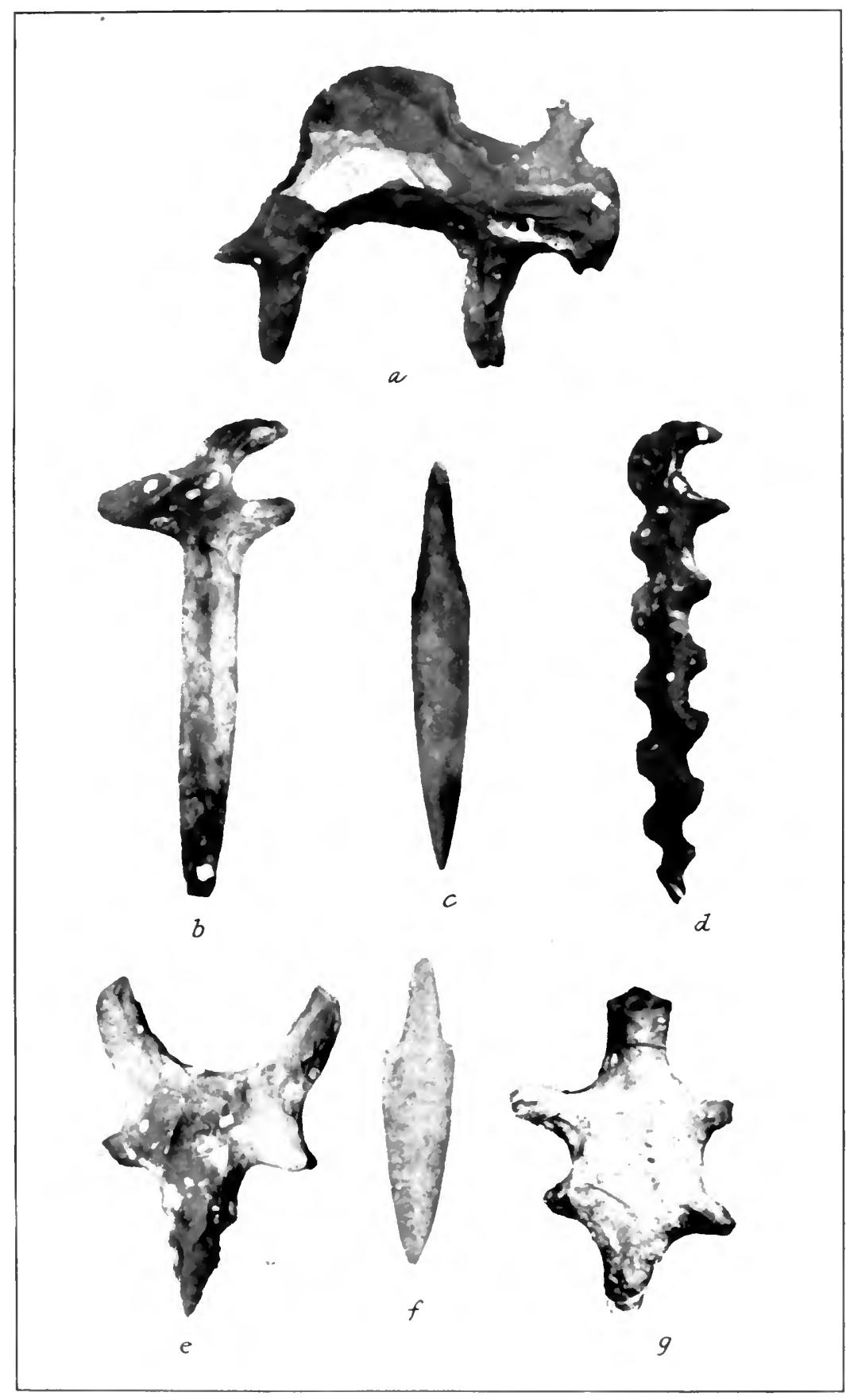

STONE OBJECTS FROM MOUND NO. 10 

side of the base, and two crescentic objects chipped from chert, somewhat resembling that seen in plate $15, e$, but smaller, without projecting spines at the convexity of the crescent, and altogether more crudely and carclessly made.

After the sand and lime liad been removed from this chamber to a depth of nearly 30 feet it was found that the walls became continuous with the solid foundation of masonry upon which the mound stood. This was very difficult to penetrate, and so far as was ascertained contained nothing further of interest. The roof of the chamber was next attacked from the summit of the mound. To a depth of nearly? feet nothing was found but fine, brown alluvial soil, full of the roots of plants and trees. Beneath this the real structure of the mound began, for not so much as a solitary potsherd or chip of flint was found in the earth

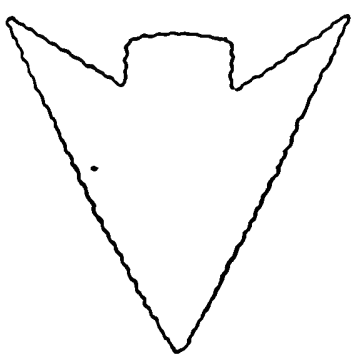

FIG. 32.-Obsidian arrowhead from Mound No. 10. on the summit of the mound, indicating elearly that this layer had accumulated since its construction. Beneath the earth layer, to the roof of the chamber, the mound was composed of blocks of limestone of varying size, loose friable mortar, and powdered limestone. In the first $S$ feet nothing except a few potsherds was found. At this depth two shallow circular saucers, each $7 \frac{1}{2} \mathrm{~cm}$. in diameter,

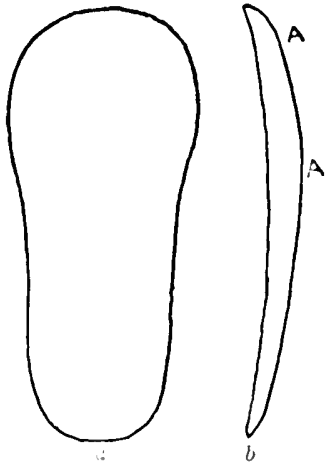

Fif; 33.-Finit oliferet from Molind $>0.10$ were unearthed. These were made of coarse red unpainted pottery, and close to them lny a finely chipped flint object (fig. 33, $a, b$ ). 'This was rounded at both ends. narrower at the handle than at the base, and markedly convex on its under surface (fig. $33, a, b)$. The front part of the under surface wins quite smooth and polished, evilently from attrition, while that purt of it marked $A$ \& bore distinct traces of blue paint. There can be little doubt thut this implement was a paint grinter, us a specimen almost exartly similar was found in a mound near Corozal, bearing truces of green paint on the under surface. Fourtern nicoly polisherl redelish stone beads, spherical in shape, tewether with four smuller beads of a lighte-green color, and a leaf-shaped spenrhead of flint, were found adjarent to the paint grinder. Immediately bencath these was formel an objeret made of what seems to be reddish-brown

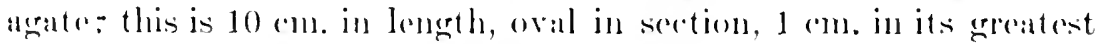
brealth, tapering off to a blunt point ut and end, and fincly polished

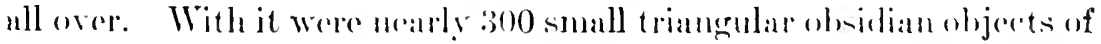
the shape shown in figure 34 . These vary in length from $1 !$ to $2 !$ em. 
They are thick at the upper angle, the side subtending this forming a sharp cutting edge. In some of the implements this edge is notched, as if from use. These implements were probably used as scrapers, or small chisels or gouges, for which purposes they would be suitable, either hafted or unhafted. It is possible that they may have been used as teeth for the sword known to the Aztec as mextatl, which was also in use among the Maya at the time of the conquest. This weapon was constructed by setting a number of sharp obsidian splinters in deep lateral grooves, cut in a long piece of hard wood, which were filled with liquid resin in order to prevent the splinters from shifting from their positions.

In the Stann Creek district of British Honduras, on the banks of the Sittec River, at a distance of approximately 15 miles from its mouth, there exists an extensive clearing in the bush known as "Kendal Estate." The soil here is remarkably fertile and well suited for the cultivation of every kind of tropical vegetable product. As has been pointed out before, wherever throughout northern Central America one finds patches of exceptionally rich soil, there, on clearing

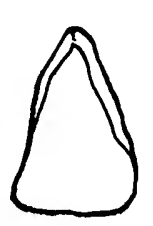

FIG. 34.-Olısidian olject from Mound No. 10. the bush, will be found in greater or less numbers the mounds erected by the former inhabitants, together with the indestructible refuse usually associnted with former village sites, as fragments of pottery, flint and obsidian chips, broken and rejectod implements and weapons, shells of various edible shellfish, clay boads, net sinkers, malacates, broken rubbing stones, etc. The converse of this holds true to some extent, as one of the guides relied on by the modern degenerate Maya Indian in his annual selection of land for a milpa, or corn plantation, is the number of mounds which he finds upon it. Indeed this remarkable index as to the degree of fertility of the soil appears to bo almost the only useful heritage transmitted to him by his courageous and comparatively highly civilized ancestors.

\section{Mound No. 11}

Mound No. 11, at Kendal, occupies a conspicuous position upon the summit of a small natural elevation, situated on the left hank of the river close to its margin. It is 60 feet long, 40 foet broad, and 20 feet high, its long diameter running due east and west. An exeavation was made into the north slope of the mound, which exposed a three-walled chamber, 8 feet in length by 4 feet 8 inches in width. There was no wall on the south side. The north wall, owing to the outer slope of the mound trending over it, was only 1 foot in height; the cast and west walls were each 4 feet high. All three walls were about 18 inches thick. The chamber was packed with water-worn 



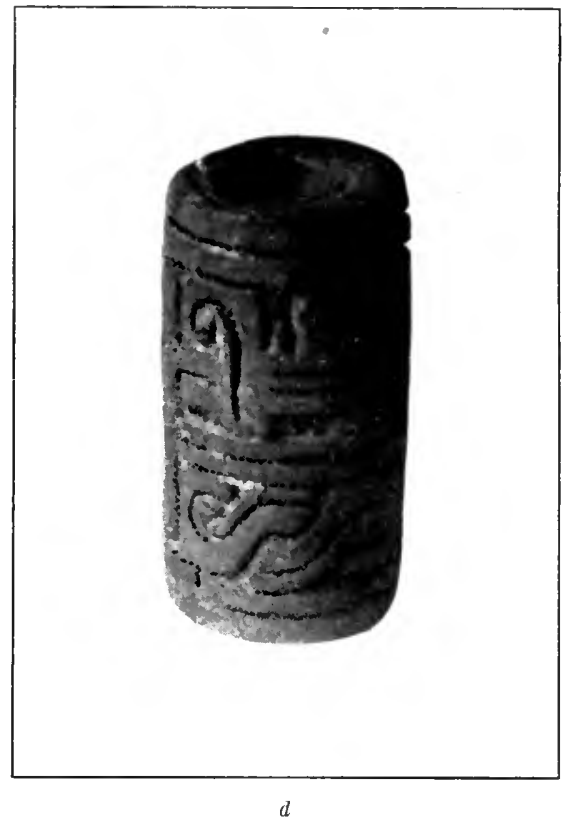

$a$

$b$

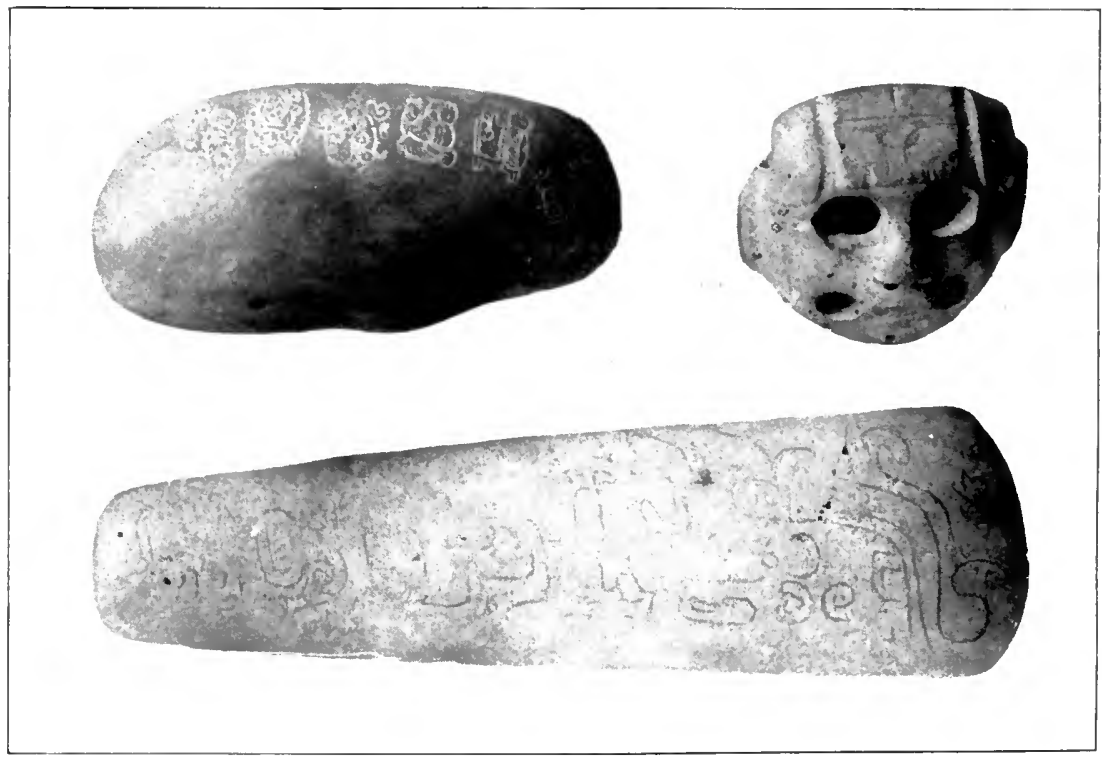

$c$

a. MODEL OF JADEITE BIVALVE SHELL, b. LIGHT-GREEN JADEITE MASK. c. AX HEAD, OR CELT. d, TERRA-COTTA CYLINDER 
bowlders and earth, among which nothing was found but scattered patches of charcoul, with a fow small red pots, so rotten and friable from long exposure to the damp that it was found impossible to remove them. Had thero over boen bones in the chamber, as seems probable, they must have completely disintegrated long before from contact with the damp clay. The floor was composed of flags of shale. About the center of the west wall a recess was discovered 2 feet wide by $1 \frac{1}{2}$ feet high. This was half filled with earth, in which the following objects were found:

(1) The model of half a bivalve shell in light-green jadeite, very well executed and polished both inside and out (pl, 16,a). On its outer surface, following the contour of the outer edge, are seven glyphs, the chief component of each of which is a grotesque human face. ${ }^{1}$

(2) A small mask of light-green jadeite, well polished on both surfaces, measuring approximately $7 \mathrm{~cm}$. in both diameters (pl. 16, $b$ ). Inscribed on the forehead in shallow lines are the glyphs shown in figure 35, somewhat enlarged from the actual size. Around the edge of the lower half of the mask are seven minute perforations, while ruming across the back of the forehead from ear to ear is a larger hole, evidently used for
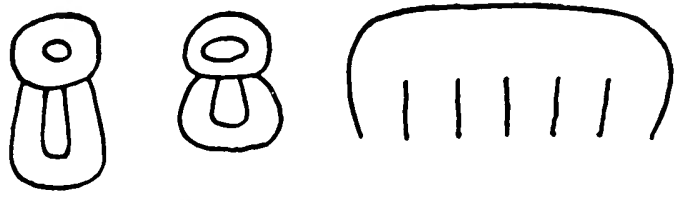

FIG. 35.-Inscription on mask, plate $16, b$.

suspension. No doubt this mask was used as a breast ornament, similar to those portrayed in the codices and on the monoliths, the small holes being intended for the suspension of the alligator-hend beals found with the mask, which again may have been connected along their outward-pointing snouts by the cytindrical beads.

(3) An ax head, or colt, of light-green stone, finoly polished throughout (p) $16, c), 21 \mathrm{~cm}$. in length by $6.5 \mathrm{~cm}$. in breadth at the cutting edgo. One side is engraved with hieroglyphs dono in shallow lines, mucle less carefully and neatly than those on the shell. The lower two-thirds of the engraved side havo ovidently bern subject od to considerable attrition, as the surface of the stone, especially along the lower third of the ax, has bean so worn away as to render tho lines almost underipherable. This inseription, somewhat smaller than the original, is shown in figure 36 . With these engraved objects wore a number of cylindrical beads, piored in their long diameter, made of very protty mottled light and dark green jadk, well polisherl. They variod from 1.2 to $1.6 \mathrm{~cm}$. in longth, and the substance of the stone from which they wore made was distinctly arytalline

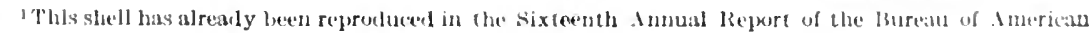
Ethnology, pl. Lyix. 
on fracture. With them were a number of small alligator heads, made of similar stono and about the same size as the beads, pierced at the base of the skull for suspension, six celts of green and chocolatecolored stone, all finely polished, varying from 9 to $18 \mathrm{~cm}$. in length, and a circular disk of iron pyrites $8 \mathrm{~cm}$. in diameter by $5 \mathrm{~mm}$. in thickness. This object was milled round the edges like a coin and perforated in the center. With it was the broken half of a similar ornament; probably both of these had been used as oar ornaments. Trenches were dug through this mound in all directions, but nothing further was found thorein.

\section{Mound No. 12}

Mound No. 12, at Kendal, was situated close to the last-described mound. Its flattened summit measured 28 feet by 20 feet; the average height was approximately 15 feet. The mound extended east and west, and on its eastern slope large slate slabs were seen protruding from the surface. On excavating round these they were found to be part of a chamber measuring 7 feet by 3 feet; the south wall had

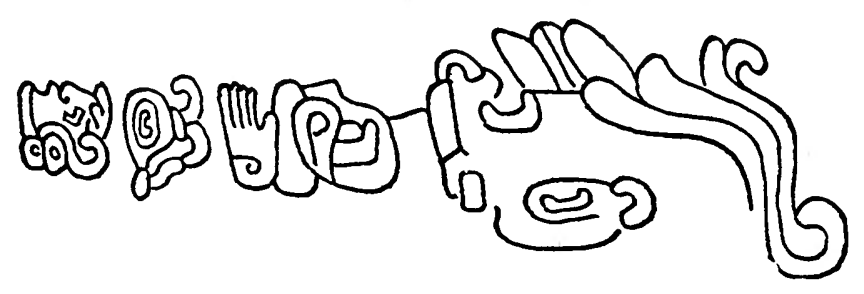

FIG. 36.--Inscription on ax head, plate 16, $c$.

caved in and the roof slabs also had been somewhat displaced. The chamber was filled with earth, on removing which the following objects were found upon the floor slabs: (1) Three nearly spherical red pots, averaging 6 inches in diameter; they were so rotten from the effect of moisture that it was impossible to remove them. (2) Two small, rather erudely executed human faces cut in mottled jadeite, and fincly polished, with which were three green jadeite beads. (3) A small quantity of greenish powder. (4) Four small chisels of polished greenstone, varying from 2 to $4 \mathrm{~cm}$. in length. (5) One chisel made of very soft gray stone, which had been covered extemally with greenish paint somewhat resembling enamel, and very closely simulating the genuine greenstone chisels with which it was placed, except that it was much lighter in weight. Instances of counterfeit implements and ornaments buried with the dead have been found more than once throughout this area.

Excavations we made along the flattened top of this mound, and about 16 feet to the westward of the first one a second grave was discovered. This was in a much better state of preservation than 
the first, as all the walls and the roof were in situ. It was composed throughout of large flat irregular slabs of slate, averaging about 2 inches in thickness. It measured 8 feet by 2 feet by 2 feet in height. The chamber was filled with earth, and the roof was not more than 6 or 8 inches below the surface of the mound. The following objects were found in this chamber, all resting upon the slate slabs which formed the floor. At the north end five nearly globular red earthenware pots, of rather coarse manufacture, each containing a stone celt, were found. These pots had been packed closely together, in earth, and over them a large slab of slate had been placed as if to protect them; this, however, it failed to do, as the pots were so saturated with moisture that it was found possible to remore only one unbroken. The celts areraged 6 inches in length; all were well made and polished; four were of greenstone, one of a bluish-gray stone. Close to the pots were found a small jadcite face and three greenstone beads or pendants. Nearer the center of the floor of the rhamber were found two small cubical objects of light greenstone $1 \mathrm{~cm}$. in diameter, very closely resembling dice, with a geometrical device inseribed in rather deep lines upon two of their opposed surfaces; these might have been seals or stamps, or they might have bern used in playing some game. With them were a small solid cylinder, of light greenstone, finely polished for suspension, 12 small obsidian knives, seemingly quite new, as they showed no signs of notching from use, and six convolvulus-shaped ornaments of light greenstone, fincly polished, which had probably been used as ciar plugs. Close to the last lay a hollow cylinder of extremely hard terra cotta 7 cm. in height, inseribed externally with a geometrical deviee in low relief (pl. 16, d). This objecet was undoubtedly a "ylindrical seal or stamp for use on a handle; similar specimens are not uncommon in the south of British IIonduras and in Guatemala, though in the morth of the colony and in Yucatan they are of much less frequent oecurrence. Small patehes of chareoal and of greeri powder wore found in several places seattered over tho floor of this chamber. Nothing further was found in this monnd, which was composed throughout of anth and water-wom bowlders.

Severnl more mounds wore excavated at Kindal, but nothing wa found in them. 'They were all composed of earth and larere, waterworn bowlders, the formere greatly predominating. (Clese to many of the mounds a decp excavation in the surface is to be seren, from which the material to construet the mound was evidently talene These mounds form a deriderd contriat to those in the north of British Ilonduras and in southern Yucatan: they are lower, flatter, mose diffuse and irregrular in outline, with the line of demareation between the hase of the mound and the surrounding soil rerre poorly defined. The northern mounds are more clearly defined. with stoper 
sides, smaller summits, and base lines easily distinguishable. The reason for this difference is to be sought in the material from which the mounds were constructed, which in the south is clay, with a small admixture of river bowlders, both of which are easily washed down by the torrential tropical rains of the district. Year by year

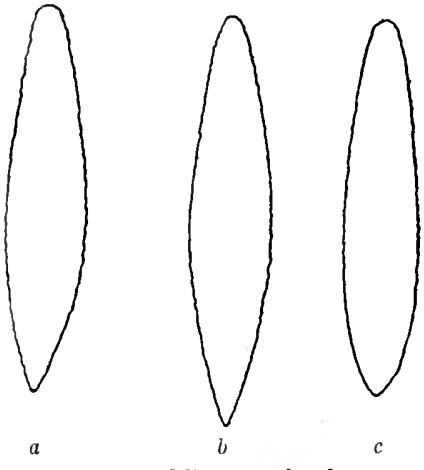

FIG. 37.-Flint spearheads. the mound becomes flatter and less well defined, till at length most of these mounds will be hardly distinguishable from the surrounding earth. In the north, on the contrary, the mounds are built of large blocks of limestone, with only a small admixture of earth and limestone dust. In many cases the blocks are mortared together, and in nearly all cases layers of cement are alternated with layers of stone. The whole forms a practically solid block of masonry, capable of withstanding for all time the less heary rainfall of this part of British Honduras and Yucatan. About the center of a triangular space, bounded at each angle by a small mound, situated close to the mound last described, was found a piece of water-worn rock measuring 4 feet 10 inches in length, which had evidently been carried up from the river bed a quarter of a mile away. Three or four inches of it appeared above the soil. Beneath the rock extended a layer of water-worn river stones to a depth of 2 fcet. Among these were found numerous fragments of pottery and patches of charcoal. On the western side of the rock, close to its elge, and buried 10 inches beneath the surface, were found three rather well-chipped flint spearheads, the largest of which was $25 \mathrm{~cm}$. in length (fig. $37, a, b, c)$; these were placed erect in the earth, points upward, and close to them lay the small, eccentrically shaped object seen in figure $38, b$, very well chipped from dark-blue flint, measuring $7 \frac{1}{2} \mathrm{~cm}$. in length. A few feet to the north of these objects, buried at about the

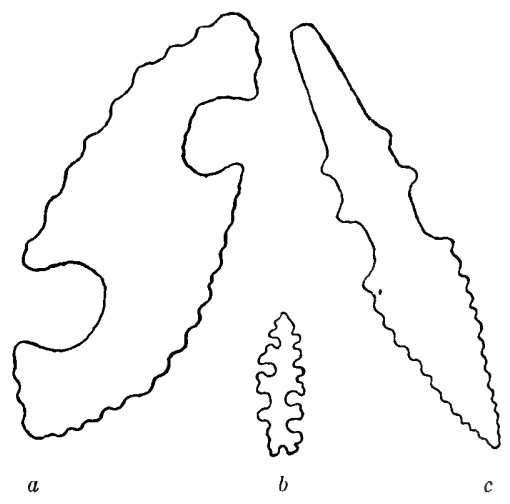

Fig. 38.-Flint objects. same depth and quite close to the rock, were found the serrated flint spearhead shown in figure $38, c, 27 \mathrm{~cm}$. in length, together with the eccentrically shaped object seen in figure $38, a, 28 \mathrm{~cm}$. in length; both of these were placed perpendicularly, the spearhead point upward.

About $1 \frac{1}{2}$ miles from the rillage of Benque Viejo, in the Western District, is the only considerable aboriginal building in British Hon- 
duras, still in a fairly good state of preservation. This is a two-story temple standing upon a small natural elevation. Each story contains 12 small rooms, three on the north side and three on the south side, each of which has a narrower room in the rear. The central rooms are 27 feet in length, the side rooms 17 feet 6 inches. The brearlth of the smaller rooms is 4 feet 6 inches; the dividing walls are 3 feet thick. All the rooms in the lower story are filled in with large blocks of stone, loosely held together with a small amount of mortar. This seems to have been a favorite device among the Maya architects, its object probably having been to give greater strength and stability to the new upper story erected upon a building of older date. All the rooms are roofed with the triangular so-called "American arch." The height of the rooms is 5 feet 10 inches to the top of the wall, and 5 feet 10 inches from the top of the wall to the apex of the arch. Nlt the rooms had been covered with stuceo, and upon the wall of one of the iuner chamhers completely covered over with green mold the devices shown in figure 39 were found, rudely scratched upon the stucco. In both the upper and the lower part of the drawing are what may be taken as crude representa-
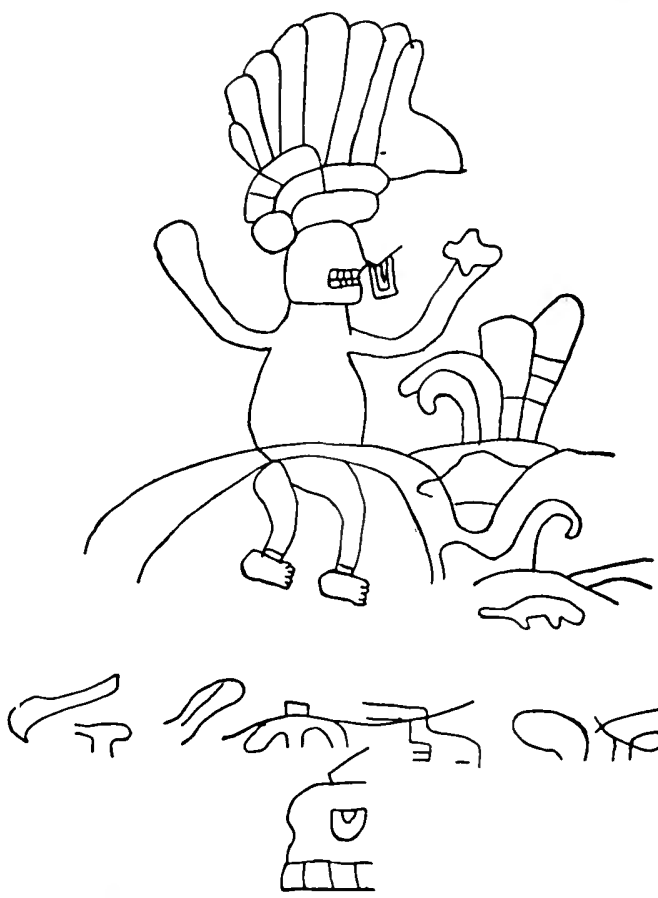

FIg. 39.- hevices seratched on stucco in ahoriginal luilding. tions of "Cimi," the God of Death, probably, like the "grafiti" of Rome and Pompeii, scratehed on the wall after the abandomment of the temple by its original builders.' Whoerer executed the drawing must have had some knowledge, however crude, of Maya art and mythology, as the Cimi head shown in the lower and the comventional fenther ormaments in the upper part of figure 39 are ummistakably of Maya origin. To the north of this building lies a considerable group of ruins. Amongr these there larere promidal

1. Similar graliti were discovered on the wall of a temple at Nakum, in tillatemalab. Sien Tozzer, l're-

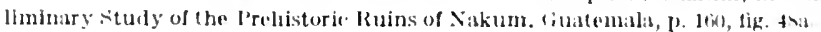


structures are conspicuous, which no doubt at one time carried small temples upon their summits, some remains of which are still to be seen. At the base of these pyramids stand three sinall plain stelæ, quite unornamented. Upon the summit of one of these mounds the eccentrically shaped implements shown in figures 40 and 44 were found. Of these, figure $40, a, b$, and figure $44, m, n, o, p$, are of obsidian, while the rest are of flint. Sixty-four of these objects were found in all, at depths varying from one or two inches to a foot beneath the surface; all were within an area of about 2 square yards. Some of the objects, especially the obsidians, were chipped out with great care and accuracy; others were merely flint flakes with a

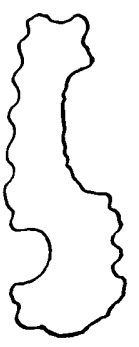

$\imath$

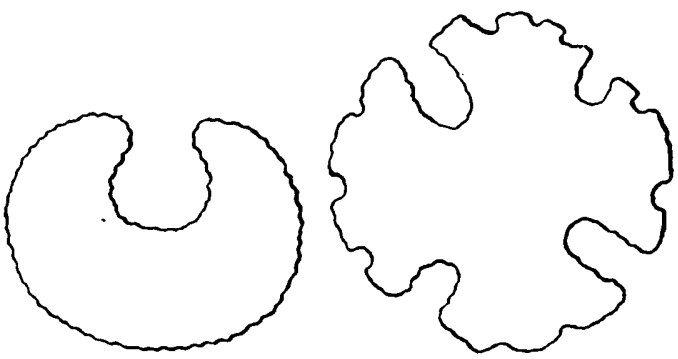

$d$

Fig. 40.-Eccentrically shaped implements found at summit of mound.

few shallow indentations chipped in their sides. On the south side of the largest of the pyramids stood a large sculptured stela, the upper part of which had been broken off and lay close to

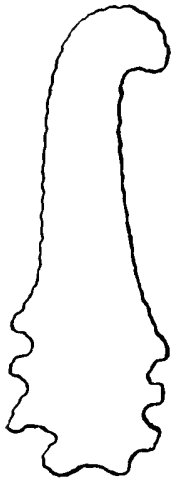

FIG. 41.-Flint object found at hase of stela. the lower part, which was still embedded in cement. The sculptured part of this stela measured 10 feet 2 inches in length by 4 feet 3 inches in brearth, and about 16 inches in

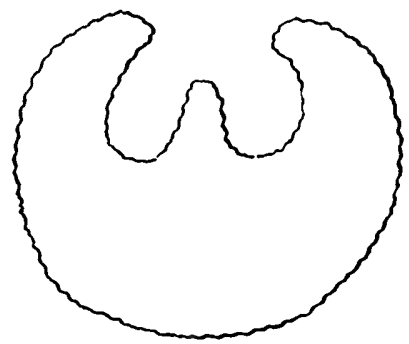

Fig. 42.-Flint ohject found at base of stela. thickness. 'The sculpture, which is in low relief, represents a captire, or sacrificial victim, prone on his face and knees, while above him rises the figure of the priest or warrior, with elaborately decorated feather headdress, holding in his extended right hand a small

figure of the manikin god. The limestone from which the stela is cut has been rery much defaced by the weather, and the finer 
details of the sculpture can not now be deciphered. 'The back and sides are plain and unseulptured. Close to this monolith lay a small stone altar, 2 feet 6 inches by 2 feet 4 inches; on its upper surface is represented the figure of a skeleton with head bent over the extended right arm, while the left is held in to the side, the elbow joint at right angles. In front of the skeleton is a double row of hicroglyphs, each row containing 7 glyphs, most of which are in a fairly good state of preservation. An excavation was made round the part of the monolith still standing. It was found to be surrounded by a solid foundation of blocks of limestone, held together by cement,
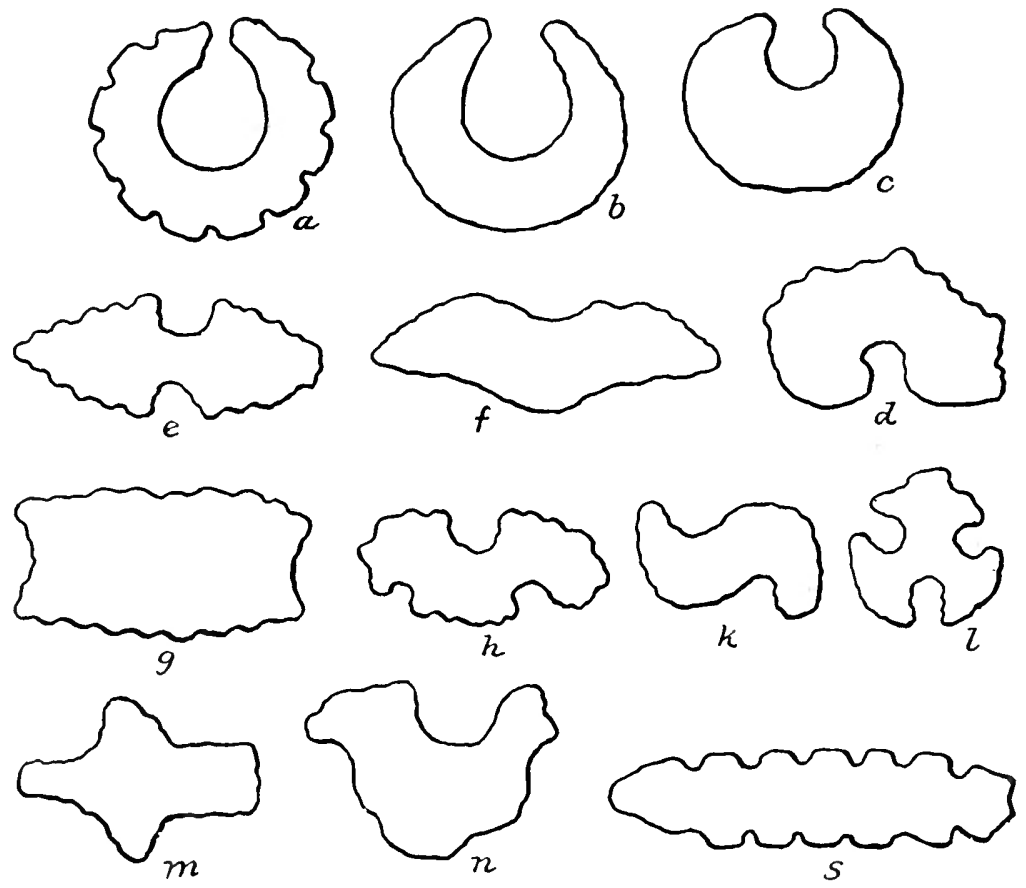

Fra, 43.-Fints found in ruins at Naranjo.

among which were found, near the base of the stela, and actually in contart with it, the two eccentrically shaped flint objects shown in figures 41 and 42 . In excarating a stcla at the ruins of Naranjo, Republic of Guatemula, Teobert Maler found the flint illustrated in figure 43, $a$, and in clearing another stela at the same ruins $2+4$ similar flints were found (fig. 4.3, $b-s)$. Of these he says:

During the excavation of this "starfish stola" quite a collection of very interesting flint ormaments, 24 in number, "ane to light. Among them were creserents, suld

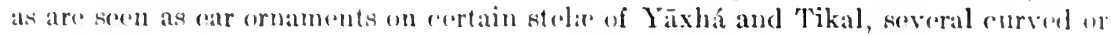
ron S-shaped pieces, which, perhapes, wore used as nose ornaments, a serrated lanep and a serrated plate, a piece in the shape of a cross, and one composed of thren leaves.

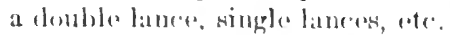

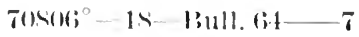


We may assume that near many stelæ, as well as in the interior or on the exterior of temples, in addition to incense burners and sacrificial bowls, there were placed certain death's-head masks or other figures of perishable material tricked out with ornaments, feathers, and locks of hair, which have long since mouldered away, leaving behind only those of indestructible stone. For elsewhere, in the vicinity of stelæ, objects of flint and obsidian are found in addition to pottery sherds. ${ }^{1}$

It will be scen that figure 43 , a, from Naranjo is practically identical with figure $44 ; h$, from Benque Viejo, as is figure $43, c$, from Naranjo with figure $40, d$, from Benque Viejo, and figure $43, k$, from Naranjo with figure $44, k$, from Benque Viejo, while
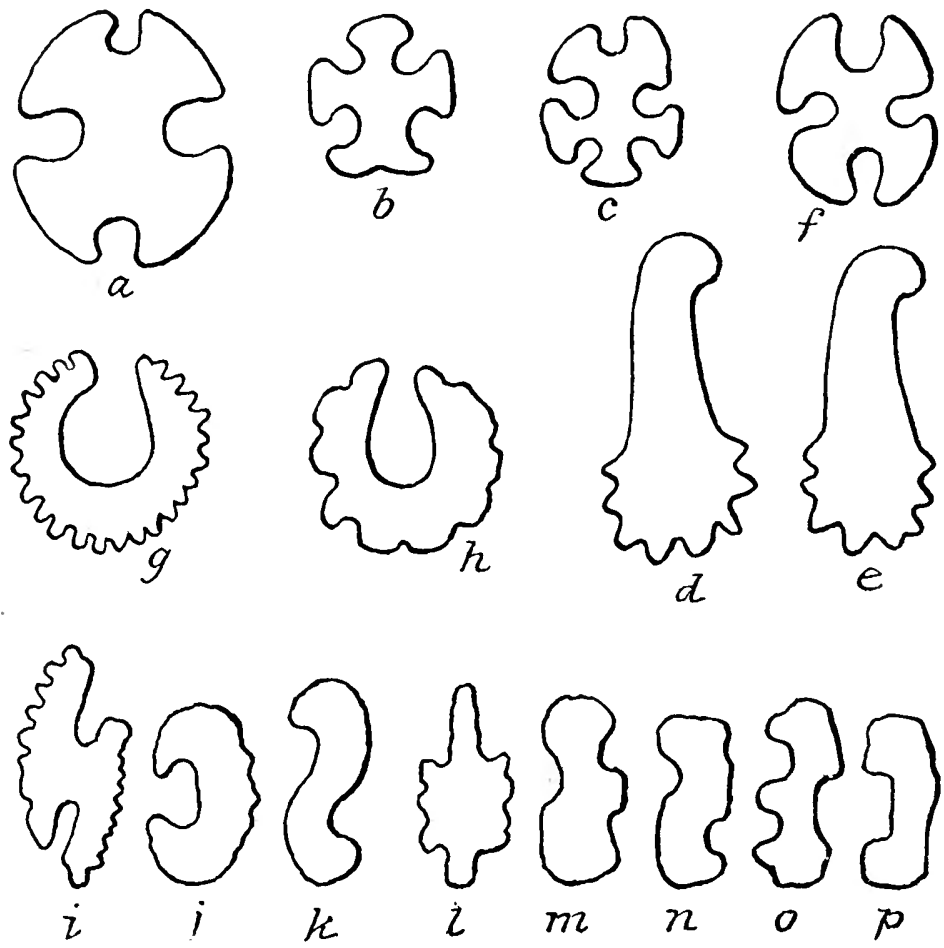

FIG. 44.-Objects from Benque Viejo.

the objects shown in figure $43, h, l, m$, respectively, from Naranjo very closely resemble those secn in figure 44,,$a$, $l$, from Benque Viejo.

Close to Succots, which is an extension of the village of Benque Vicjo, a small mound was opened by Dr. Davis some years ago, within which were found the objects illustrated in figure 45 . These are all of obsidian and of very eccentric and irregular shapes. The object shown in figure $45, c$, closely resembles that shown in figure $43, c$, from Naranjo, and that in figure 40, $d$, from Benque Viejo, 
and still more closely figure $44, p$, from Benque Viejo, both being made of obsidian.

\section{Mound No. 13}

Close to Corozal, in the northern district of British Honduras, the sea in its gradual encroachment along the coast had partially washed away a small mound. On the beach, hy the side of the mound, wore found a few fragments of human long bones, a small triangular arrowhead or javelin head of black flint, a number of potsherds of coarse, thick, reddish pottery, and two small obsidian knives. These had evidently been washed out of the mound by the sea. The remaining part of the mound was dug down. It was found to be 18 feet in diameter, less than 4 fret high at its highest point, and built throughout of water-worn stones, sand, and earth. Near the center and on the ground lerel were found human vertebra and parts of a skull, probably belonging with the leg bones found on the
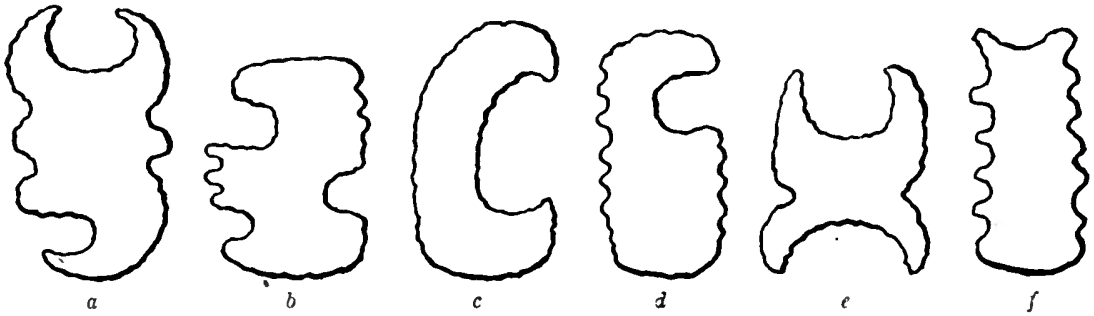

FIg. 45.-Obsidan objects found in a mound near Benque Viejo.

bearli. Close to these were found a small threr-legged earthenware beald vase, containing two pottery and one small polished greenstone brad, together with one eccentrically shaped flint object. This is probably meant to represent a "quash," or picote, with bushy tail coiled over his back. It is rather neatly ehipped from dark-yellow flint. It measures nearly 3 inches from the curve of the tail to the tije of the forepaw.

\section{Mouxd No. 14}

Tho next mound in which an eccentrically shepod flint was discovered is a rery larero ono situated far away from any settlement, at the headwaters of the Rio IIonde, in northern British IIonduras. The stone implements found in it lay near the summit, about a couple of feet beneath the surface. They were ciscovered aceidentally by an Indian (from whom they wore purchased) while diggring out a halib, or gihmut, from its hole, and consist of : (a) $A$ spindleshaperd stone brazo 12 inches long by 9 ? inches in circumference, fimely polisherd from grinding corn on al metate. (b) A chipperd flint brazo, $7 \frac{1}{2}$ inches long by $10 \frac{1}{2}$ inches in circumference, polished on one 
side only. Flint brazos are exceedingly rare, as the rough surface necessary for corn grinding must have been difficult to producc on so refractory a material. (c) Eight stone ax heads, varying from $3 \frac{1}{2}$ to $8 \frac{1}{2}$ inches in length. (d) A dark greenstone ax head, $9 \frac{1}{2}$ inches in length, with two shallow notches, one on each side of a shoulder situated 3 inches from the base, probably intended to afford greater facility in laafting the implement. (e) 'Two well-chipped flint spear-

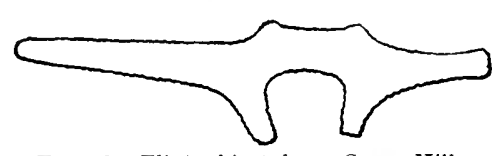

Fic. 46.-Flint object from Seven IIills. heads, one $10 \frac{1}{4}$, the other $7 \frac{1}{2}$, inches in length. (f) An oblong block of flint $6 \frac{1}{2}$ inches in length and $6 \frac{1}{2}$ inches in circumference. 'This hat probably been used as a hammerstone, since it exhibits well-defined percussion marks at each extremity. (g) A rather roughly chipped stellate disk of flint, 10 inches in diameter, with 13 sharp-pointed triangular rays or spines, each about 2 inches in length, at equal intervals around its periphery. Near the center of this object is a natural hole $3 \frac{3}{4}$ inches in diameter.

The upper part of this mound consisted of earth and blocks of limestone; the lower part was not excavated. The implements were found lying close together in a cache, loose in the soil. Numerous rough potsherds were found, but there was no trace of human interment discorered.

In the southern part of British Honduras, not far from Punta Gorda, is a group of small natural elevations, known as Seren Hills. Upon the summit of the highest of these, some years ago, the object illustrated in figure 46 was found. This somewhat resembles a horsoshoe with two long bars, each tapering off to a point, projecting from either side. It is very meatly chipped from grayish flint. Its extreme length is $\mathbf{1 6}$ inches. This implement was found just beneath the surface, covered only by a few inches of soil. At a later date a number of trenches were dug on the summit of this mound, but nothing except potsherds of various kinds with flint and obsidian chips camo to light.

In figure 47 is seen one of the finest of

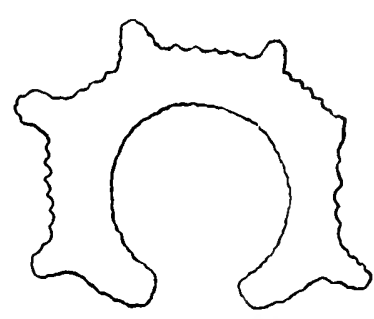

FIG, 47.-1Iorseshoe-shaped flint object found near San Antonio. these eccentrically shaped flints ever found in this part of the Maya area. It is horseshoe-shaped, chipped to a sharp edgo all round, and has six sharp spines projecting from the outer periphcry (one of which has been broken off, as shown in the figure), with shallow indentations between then. The implement, which is 35 cm. in its greatest liameter, is made of nearly black flint, covered with a beautiful creamy white porcelain-like patina. It 
was found by an Indian in the neighborhood of San Antonio, on the Rio Hondo, which here forms the boundary line between Mexico and British Honduras. He was idly scratching on the top of a small mound, buried in the bush, with his machete, when a few inches below the surface he came upon this very remarkable flint. Unfortunately, he took no pains to locate the mound, and as the bush in this neighborhood is literally covered with mounds in all directions, he has never been able to find this particular one again.

The implement shown in figure 48 was dredged up from the River Thames, near London, at a spot where foreign-going ships were in the habit of dumping their ballast. There can be little doubt that it came originally from British Honduras, as flint implements of such large size and of this peculiar type are not found outside the Maya area. This object, as may be seen, is a crude representation of the human form; it is $9 \frac{1}{2}$ inches in length and is neatly chipped. A closely similar anthiroponorphic specimen is preserved in the Northesk collection, a cast of which may be seen in the British Museum.

It is extremely difficult to form any satisfactory theory as to the use of these eccentrically shaped flints which will cover all the instances in which they have been found. Teobert Maler, julging by the small specimens, closely packed, which he found at Naranjo, considers that they may have been used as omaments upon death'shead masks, placed near stelæ and temples, the more perishable parts of which have disappeared. This theory could hardly apply to the immense specimens from the Douglas, Orunge Walk, and Seven Hills mounds, some of which are, moreover, obviously intended as weapons,

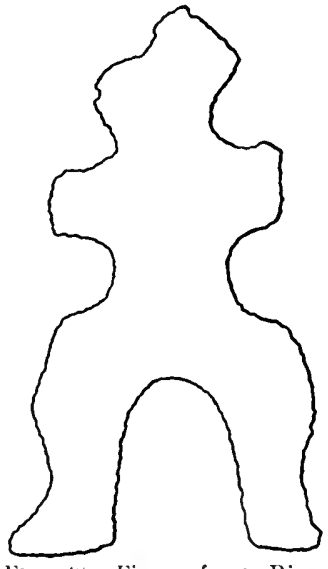

Flit. 4 - Figure from River Thames, near London.

and not as ormaments. Stevens, the author of "Flint Chips," with only the three large specimens found in a care inlanel from the Bay of Hemduras to judge from, considers that they may have served as "wenpons of parade, like the state partisan or halbert of later times:" it is perfertly obvious, however, that the zoomorphic forms from corozal and Douglas, and the small specimens from Bongue Viejo, Naranjo, Kondal, and Santa Rita, could not have beon intended for this purpose. Finding small, beantifully ahipped crescents, crosses, and rings of obsidian and varieolored flints, as have been discovered at Benque Viejo and Sureots, one would be inelined to think that they were intended as earrings, gorects, and breast ormaments, esperially as one sees such forms frecpuently recurringr

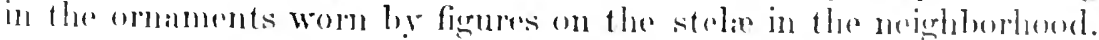
Finding the louge flints pietured in plate $15, b, d$, esperially when 
associated, as they were, with the largo flint spearheads illustrated in plate $15, c, f$, the conclusion that they were intended as weapons would be almost irresistible.

The number of these objects found at each of the 11 sites which have been described varies from 1 to 64 . On 5 of the 11 occasions they were undoubtedly associated with human interments; in 4 of the remaining 6 they were found lying, superficially placed, on the summits of mounds, which for various reasons were not thoroughly excavated, and may or may not have been sepulchral in function; in the two remaining finds the flints were placed closely

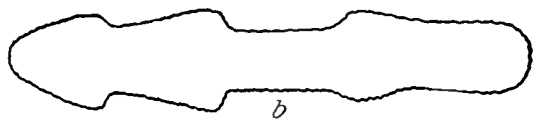
adjacent to sculptured stelæ, and these again may have been used to mark the grave of some priest or eacique, though they more fre-

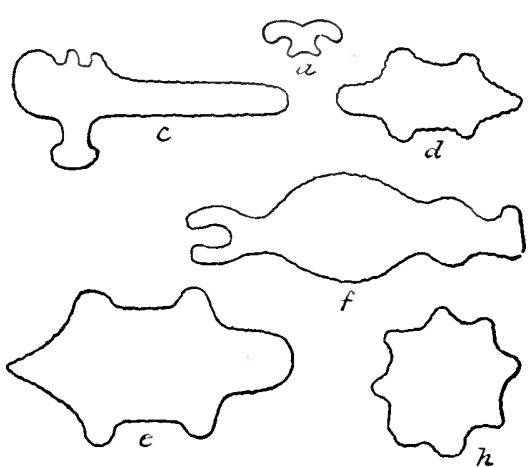
quently marked the lapse of certain time periods. The commonest form assumed by these objects is the crescent or some variant of it. Of the 11 sites excavated, this form was found in no fewer than 8. The crescent is in some cases quite plain, in some indented or spiked along the convexity, and is in one instance furnished with long spines on $t$ ach side.

In every instance (except that of

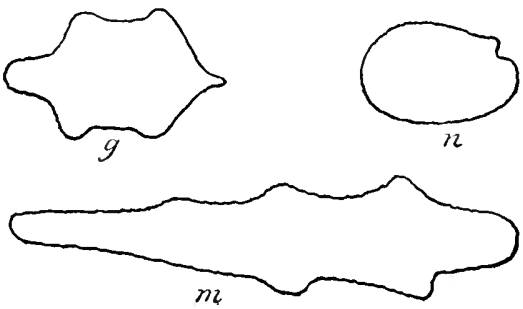

Frg. 49.-Fint objects from Tennessee. the chambered mound at Douglas) where these implements were found in mounds they were placed quite superficially at the summit of the mound; indeed at Benque Viejo, Seven Hills, and Santa Ritaitseems probable that they had not been buried originally at all, but merely placed upon the summit of the mound and in course of time became corered with a layer of humus from decaying vegetation in the vicinity.

Similar flint objects have been found in other parts of the world, notably at Brionio in Italy and in Stuart, Smith, and Humphrey Counties, 'Tennessee. In figure $49, b-n$, are shown somewhat rough outline sketches of the Tennessce objects, and in figure 50, $a-p$, are represented a selection of the most important objects found at Brionio, now in the collection of the late Professor Giglioli at Florence. 'The Tennessee objects are to be seen at Washington. The latter are small when compared with the largest of the Maya 
specimens, but are neatly chipped, whereas the Brionio objects are very crudely blocked out, mostly from black flint.

It will be observed that figure $49, c, d, g$, from Tennessee, shows specimens almost identical with figure $50, p$, from Brionio, and with the turtle, pictured in plate $15, g$, from the Douglas chambered mound; again the spiked crescents, figure 50, $b, c, n$, from Brionio, closely resemble the very much larger spiked crescent illustrated in plate 15, e, from the Douglas chambered mound, and still more closely the spiked crescent figured in "Flint Chips" (from Wilson, Prehistoric Man, op. cit., p. 214). Though these objects are not found in Central America outside the Maya area, the Aztec were sufficiently expert in the art of flint and obsidian chipping to have produced them had they wished. In figure $49, a$, is seen the outline of a type of labret worn by the Aztecs, chipped out of both flint and obsidian, which compares favorably in workmanship with any of the objects from the Maya area.

In reviewing the evidence it would appear that these eccentrically shaped objects were not employed either as implements or as weapons, most of them being utterly unsuited in both size and shape for such purposes; moreover, none of them show any signs of wear or use. Neither were they used as ormaments, as many of them are toe large and heavy, while the more roughly chipped specimens would be quite unadapted for such a purpose. Judging by the fact that 5 at loast of the 11 separate finds

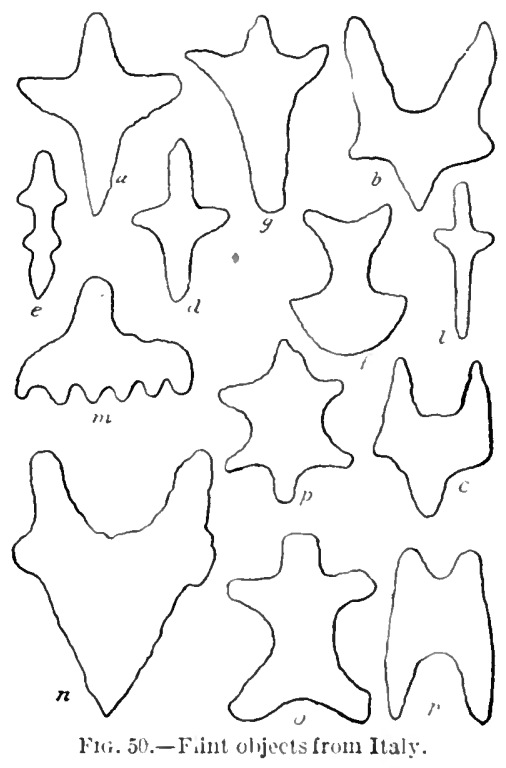
were associated with human burials, it seems probable that these objects were purely ceremonial in use; that they were most frecuently, if not invariably, buried with the dead, either on top of the sepulchral mound, in close association with the corpso, or by the side of a memorial stela; and that they were manufactured and used solely for this purpose

\section{Motril No. 15}

Mound No. 15 was situated on the south hank of the Rio IIondo, about is miles from its mouth, near the village of Sintia llelema. This wak a (onkenl mound 2.5 fort in height and 120 foret in rireumforedere at the bate. Excavation was beran at the summit of the mound, which was somewhat flattened. For the first foot the coil 
consisted of light-brown earth, which contained nothing of interest. For the next $3 \frac{1}{2}$ feet there were large blocks of limestone, the interstices between which were filled with limestone dust and débris. In these were found large quantities of potsherds, some well painted and polished, together with part of the inferior maxilla of a mediumsized carnivore, probably a puma. At a depth of $3 \frac{1}{2}$ feet a number of

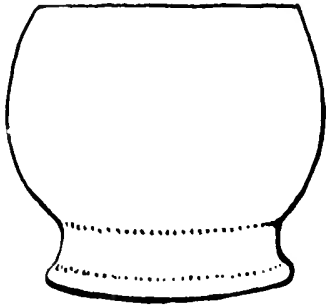

Fig. 51.-Small cup-shaped vase from Mound No. 15. stone flags, each nearly 5 feet in length and from 4 to 6 inches in thickness, were exposed; on removing these a small chamber appeared, of which the flags formed the roof. The walls of the chamber, or cist, were built of squared stones mortared together; it was 6 feet long, 6 feet high, and 4 feet broad; the floor was of lightbrown, very fine river sand. On carefully removing the sand the following objects were brought to light at depths varying from 3 feet below the surface of the sand to the bottom of the chamber: (a) A small round, cup-shaped vase, shown in figure 51, painted bright yellow and finely polished. It is $10 \mathrm{~cm}$. high by $8 \frac{1}{2} \mathrm{~cm}$. in its greatest diameter. Onc its outer surface are two grotesque monkey-like figures, the outline of one of which is shown in figure $52, a$. small thin bowl of the shape shown in figure $52, e$, painted yellow throughout, well polished, and ornamented exteriorlywith geometrical devices in red and black. A somewhat larger bowl than the next preceding, of the shape seen in figure $52, f$. The geometrical ornamentation on the outer surface is executed in low relief, and was afterwards painted over. (d) A large circular
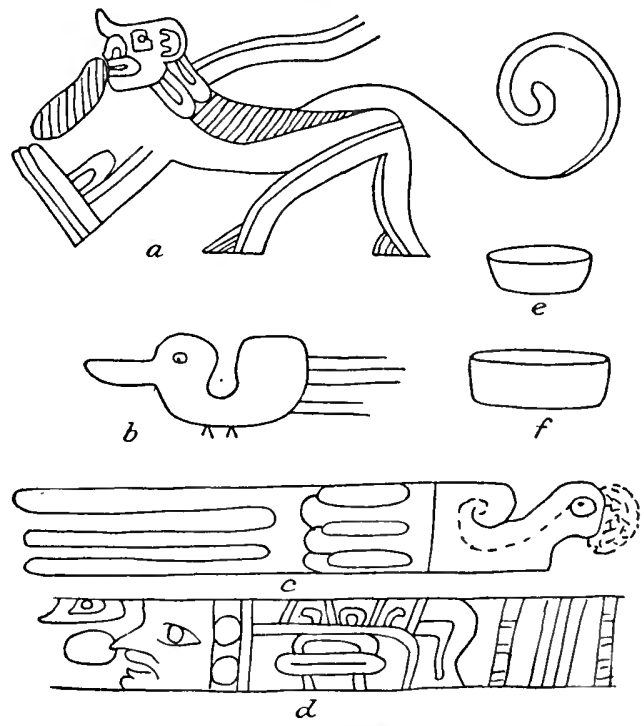

FIG. 52.-Objects from Mound No. 15.

plaque painted yellow throughout, $42 \mathrm{~cm}$. in diameter. This plaque had been polished but shows considerable signs of hard usage before burial. (e) $\Lambda$ plaquo-like vessel, $9 \mathrm{~cm}$. in height, with the design represented in figure 52, $\bar{d}$, of a human face separated from a dragon's head by the Maya numeral 7, repeated around the outer surface of its rim. A shallow plaque, $36 \mathrm{~cm}$. in diameter, painted yellow throughout, and 



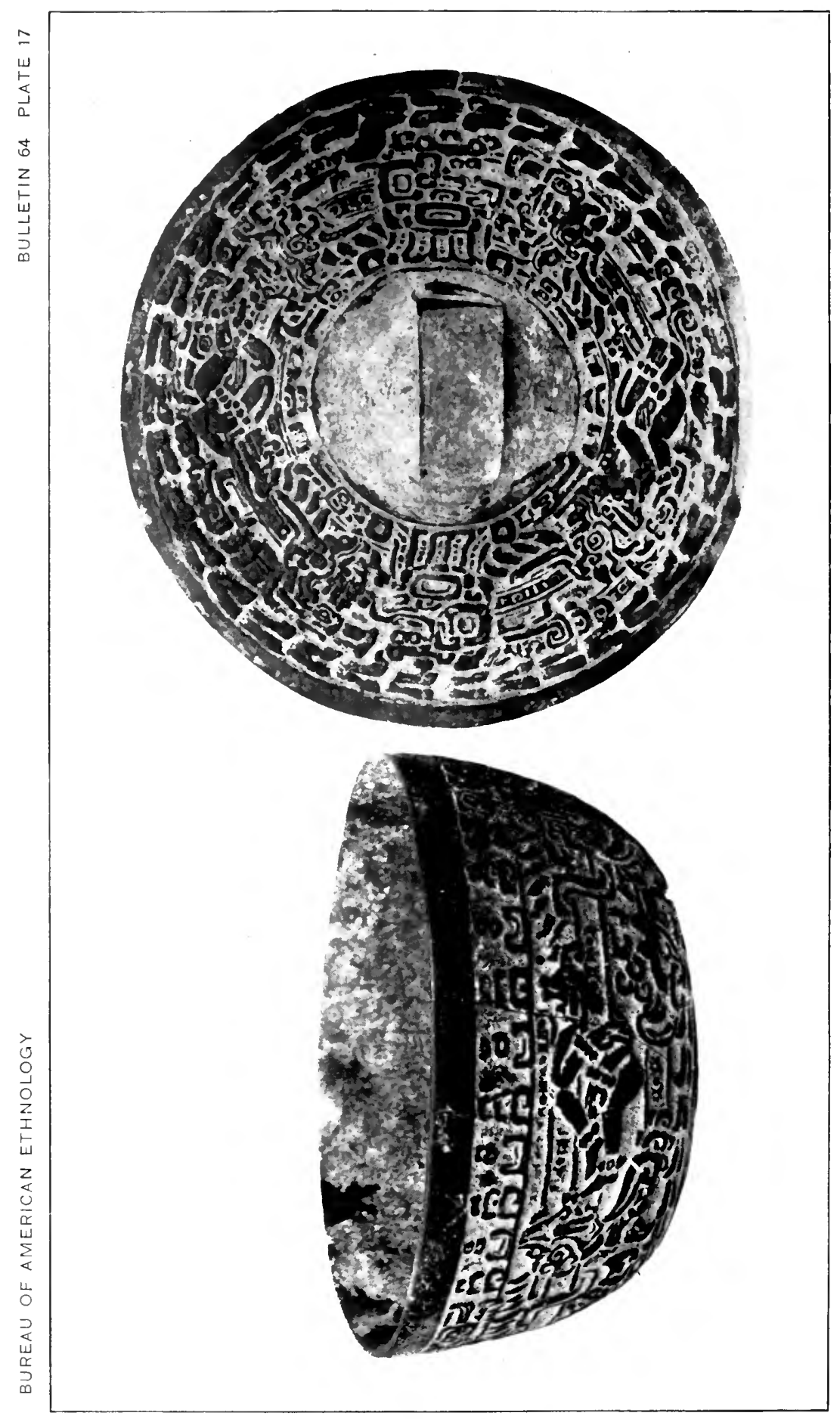

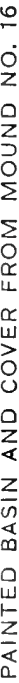


polished; on the inner surface of the rim aro repeated twree, outlined in black lines, the bird and the curious mythological animal seen in figure $52, b, c$. (g) A basin-shaped vessel, painted a deep reddishbrown and finely polished throughout, with a very attractive and intricate device of interlacing diamond-shaped figures around tho inside of the rim. (h) A vessel closely similar to the preceding, but smaller and not so well polished. It was broken into a number of pieces when found. (i) A small round pot, with flaring rim, of common red ware, showing no attempt at decoration. (j) Scattered throughout the sand, in the midst of these pots, were found 35 very small, flat, circular disks or beads, averaging about one-twelfth inch in thickness. Some were of greenstono, others of a reddish-yellow stone mottled with white. All were well polished.

On removing the sand to a depth of 12 feet the bottom of the chamber was reached. The floor, which was composed of hard mortar, measured 4 by 3 feet, as the chamber was somewhat funnelshaped, narrowing as it descended. On the bottom of the chamber were found a number of small oyster and cockle shells, with fragments of human bones. Among these was an inferior maxilla in fairly good state of preservation; from the facts that the tooth sockets had disappeared, that there was considerable atrophy along the alveolar processes and widening of the angle between tho horizontal and rertical sections of the bone, it had probably belonged to a person of adranced age.

\section{Mound No. 16}

Mound No. 16 was situated about 2 miles due north of tho lastdescribed mound, close to the north bank of the Rio Hondo, within the territory of Quintana Roo. It was discovered by an Indian, who had cut a piece of virgin bush with the object of making a milpa. The mound was 35 feet in height by 250 feet in circumference at the base; in shape it resembled a truncated cone, the flattened summit of which measured 30 feet in one direction ly 6 feet in the other. The mound was composed throughout of rough bocks of linestone, the interstiees of which were filled in with limestone dust and an unusunlly large quantity of light-brown earth. Excivation was commeneed at the top of the mound; for the first 6 feret nothing execept a few potsherds was found. Scattered through the next 2 feet of the mound the following objects were brought to light; these were mingled indisoriminately with the limestone blocks of which the mound was built, quite unprotected by eyst or chamber: (a) A basin-shaped vessel $20 \mathrm{~cm}$. in dinneter, $10 \mathrm{~cm}$. in height (pl. 17), covered by a round conical lid with a semicireular handle. Both basin and cover aro painted black and polished, inside 
and out. Cpon the outer surface of the vase and the upper surface of the lid are incised in low relief a series of pictographs, identical upon both. From the nature of the design and the fact that the vase contained a number of fragments of human bones, it seems probable that it was intended for a cinerary urn. The design is of considerable interest and worthy of detailed consideration. The most prominent object upon both the lid and the vase itself is a naked human figure in a re-

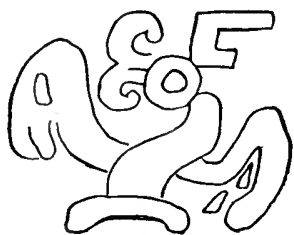

FIG. 53.-Conventionalized representation of bird on vessel shown in plate 17 . cumbent position, with the arms flexed over the chest and abdomen and the knees and thighs semiflexed. The ornaments worn consist of an elaborate feather-decorated headdress, a labret, or nose ornament (it is somewhat difficult to determine which), and large bead anklets and wristlets. Below the head, on the body of the rase, is the conventionalized representation of a bird (fig. 53) with extended drooping wings, and a rectangular object occupying the position of the beak. On the lid, probably from lack of room, this bird is represented only by the rectangular object, beneath which is seen the conventionalized serpent's head, represented only by the upper jaw, from which project the head and hand of a human being, whom it is in the act of swallowing. This monster, with a human head projecting from its mouth, is frequently represented in mounds in this area, usually in the form of a clay figurine.

The next figure is probably intended to represent Quetzalcoatl, the Cuculcan of the Maya, and God B of the Codices. It is the shrunken bearded face of an old man, with a single tooth in the lower jaw, very prominent nose, and a bird's head (probably that of the owl) in the headiless. These are all woll-recognized characteristics of this god. At the back part of the headdress of the god, and connected with it, is a human face. Immediately above the head of Cuculcan is depicted a fish, with a flower-like object in front of its mouth (fig. 54), which is probably connected with this god, who is frequently associated with objects connoting water, regetation, and fertility, as fish, flowers, water plants, leaves, and shells.

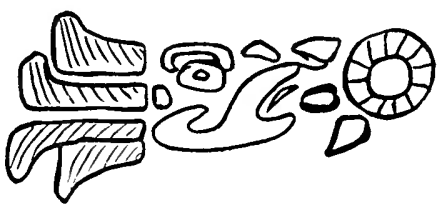

FIG. 51.-Decoration on ressel shown in plate 17.

The next figure probably represents Schellhas's God $K$ of the Codices. 'This god possesses an elaborate foliated nose, and is usually closely associated with God B, as he is in the present instance; indeed Brinton and Fewkes regard him as being merely a special manifestation of the latter god, while Spinden is of the opinion that his face is derived from that of the serpent so constantly associated with God B.' The lower jaw of the god seems to consist of a dry bone. Imme- 


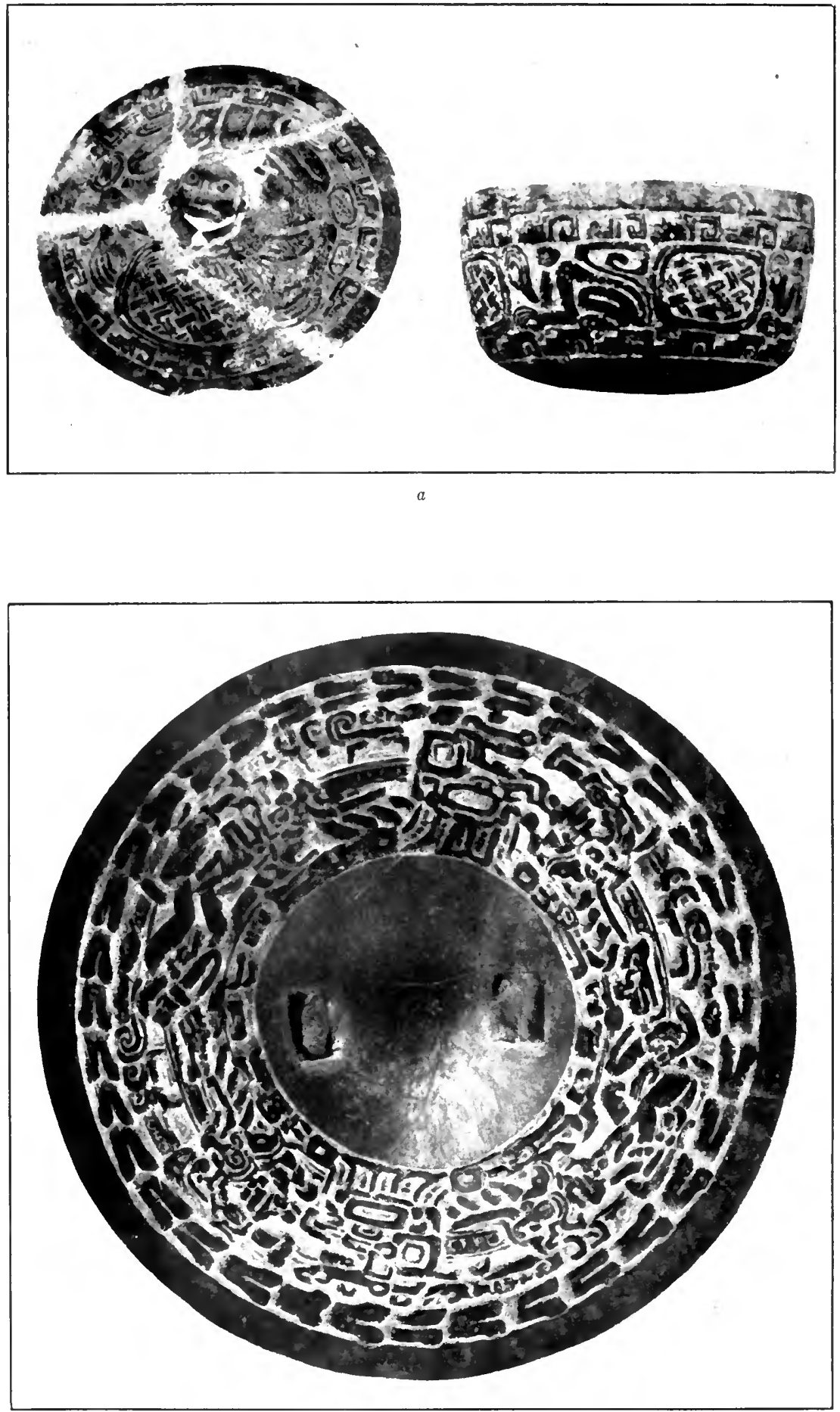
diately behind God $\mathrm{K}$ is repeated the design of the serpent swallowing a human head, above which is a striated bar, whose sole purpose secmingly is to decorate a vacant space. Above this again is a bar with feathers or leaves projecting from it, which may possibly be connected with the headdress of God B, and at the top is repeated the figure of the fish, with the circular object in front of its mouth. Next

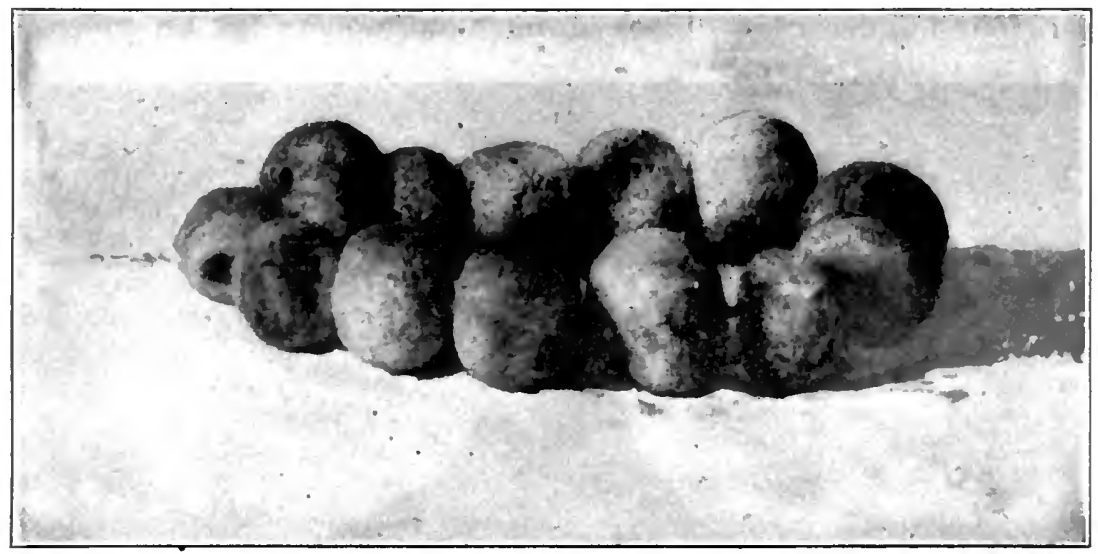

FIG. 55.-Perforated beads found in Mound No. 16.

to these is again seen the head of the god Cuculcan, after which the whole series recommences with the prone naked human figure. (b) $\mathrm{A}$ vesiel exactly similar in size, color, and shape to the one last described (pl. 1s,a). The outer surface is decorated by four curious monkeylike creatures, sculptured in low relief, separated from each other by ovate spaces inclosed in double parallel lines and filled with reresshatching. Above and below is a border of frets, also exeruted in low relief. The faces of these monkeys are represented by a simple oval, no attempt having beren made to depiet any of the features. The hands are furnished with huge clawlike fingers, and the tails, which are of erreat length, are curled over the back. The rover of this vessel (pl, 18, a) is cireular, somewhat fumel-shaped, 2:3 (m. in diameter. Lpom its outer surface is executed, in low relief, a monkey almost exartly similar to those which appear on the oviter surface of the rase, except that it is somewhat larerer

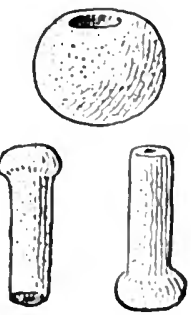

Fli, jis. - Juleill beras found in Mound No. li. and is seen in front viow, not in profile. The fares of the monkey is carefuly molked in high relief to form the hamble of the lid,

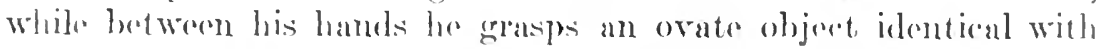
these on the rase. (a) The lid of a ressel eroresponding exaldy to the lid of the vessel first deseribed. The jout to which it

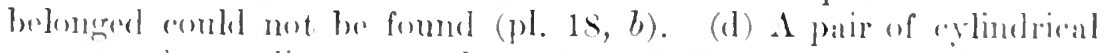

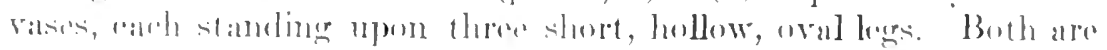


made of extremely thin, brittle pottery painted a dirty yellow and polished throughout, with no ornament except a broad red stripe, which passes obliquely around the whole of the outer surface of each vase. (e) Two shallow circular plaques, painted reddish-brown, and polished throughout, with a gtometrical device in thin black lines around the inner surface of the rim of each. (f) A quantity of bones, probably those of a halib or gibnut, and of a wild turkey. These were found under a large block of rough limestone. (g) A number of

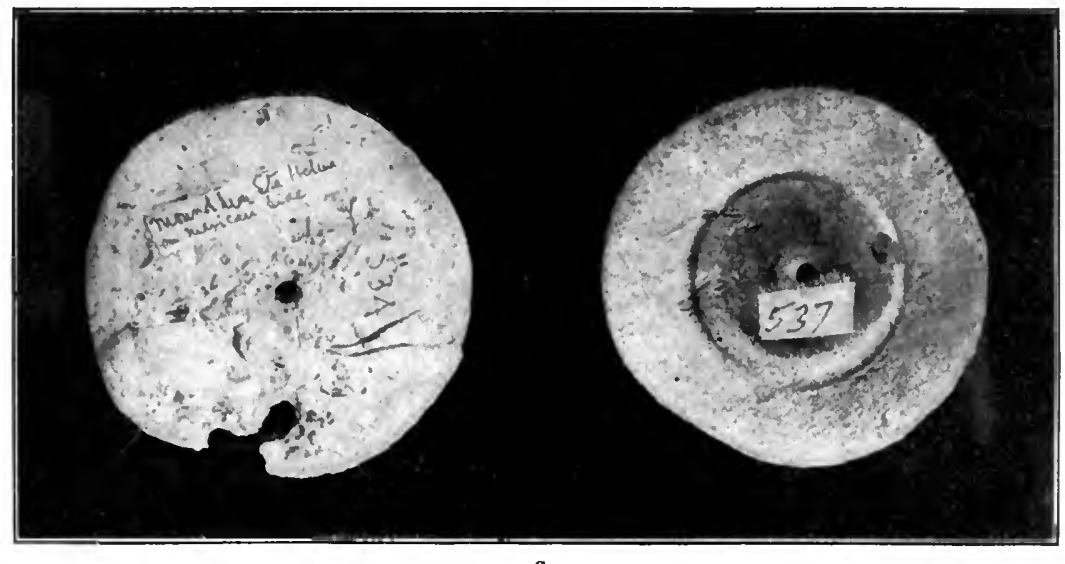

$a$

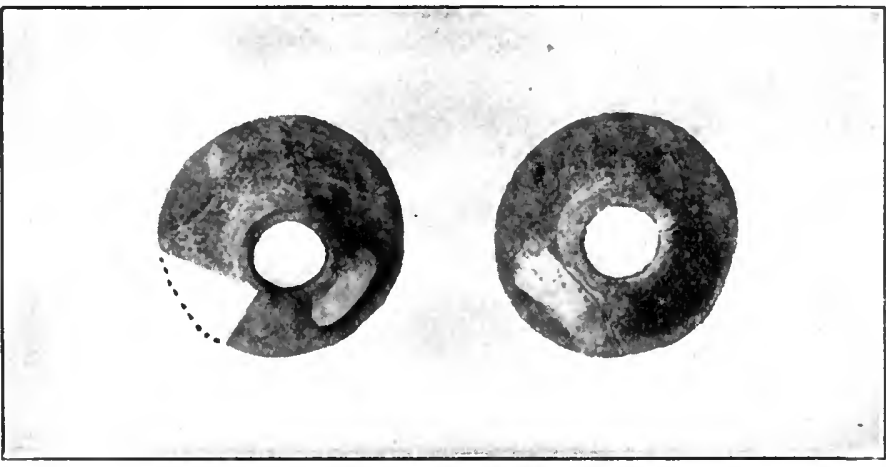

FlG. 57.—a. Circular shell disks from Mound No. 16. b. Greenstone ear plugs from Mound No. 17.

univalve shells, each about 1 inch in length, perforated at the apex in two places, as if for suspension in the form of a neeklace or ornamental border. $\quad$ With these shells was found half of a large cocklelike bivalve, painted red throughout, and perforated, possibly for use as a gorget. (h) Thirteen large, round, perforated beads (fig. 55). Some of these are reddish in color, and show traces of polishing. With these were the three jadeite beads pietured in figure 56 ; two of these

1 See Mcmoirs of the Peabody Huscum, vol, II, No. 1, Rescarches in the Valley of the Usumatsintla, where on several illustrations rows of similar shells are secn decorating the edges of the garments of the persons represented. 
are cylindrical, with a knob at one end, while the third is nearly spherical; all are finely polished; they are made of light and darkgreen mottled jadeite. (i) A single small oyster shell, with a great number of cockle shells. (j) Two circular disks of shell, represented in figure 57, a, exhibiting the front and back view. The central part is of a deep reddish color, and is well polished. Each disk is $5 \mathrm{~cm}$. in diameter and is perforated at the center. They were probably used as ear ornaments. Excavations were made in this mound to the ground level, but no additional objects wore found in it.

\section{Mouni) No. 17}

Mound No. 17 was situated within a mile of the mound last deseribed, on high ground, about $1 \frac{1}{2}$ miles from the Rio Hondo, from which it is separated by a belt of swamp. It was conical in shape, about 40 feet high, nearly 90 yards in circumference, and was built throughout of large blocks of limestone, the interstices being filled with a friable mortar, made seemingly from limestone dust, earth, and sand mixed together. Near the summit was an irregular opening, about 4 feet across, which led into a small stone-faced chamber, 15 feet long, 5 feet broad, and 6 feet high. The opening had been made by the falling in of one of the flags which formed the roof of the chamber; this was found within the chamber with a pile of débris. The floor was composed of large

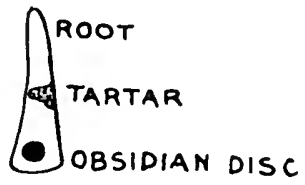

FIG. 58.-Obsidian disk in. serted in tooth of skeleton found in Mound No. 17. flat flags, on removing one of which an aperture was made which led into a sccond chamber, of exactly the same size as the first, and immediatcly beneath it. The floor of this was covered to a depth of about 12) inches with a layer of sof brown river sand, in which were found: (a) Parts of a human skeleton, seemingly belonging to an adult mulc, the bones of which were very friable and greatly eroded. In one of the incisor teeth was inserted a small disk of obsidian, the outer surface of which was highly polished (fig. 58). These ornamental tooth fillingrs are rather rare, though they have been found from time to time in Yucatan and as far south as Quirigua. They wore usually made from greenstone, obsidian, or iron pyrites, all higrly polished, the only teeth ormanented being the incisors and canines, usunlly in the upper jaw. The phurering seems to have been exclusively for ormamontal purposes, not with any iden of filling a cavity, the result of rarios in the tooth.'

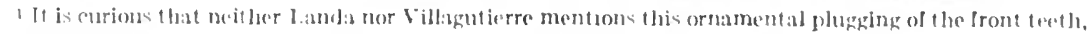

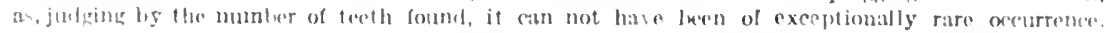

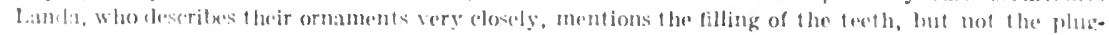

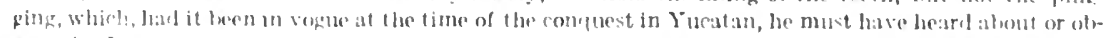

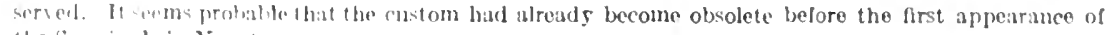
the spuniards in Incatan. 
(b) A shallow plaque, $28 \mathrm{~cm}$. in diameter, painted throughout a dark reddish-yellow, and finely polished. Upon the upper surface was outlined in fine black lines a bird, apparently a sea hawk, carrying in its claw a good-sized fish, possibly a stone bass (fig.. 59). The artist probably witnessed this event many times, as the mouth

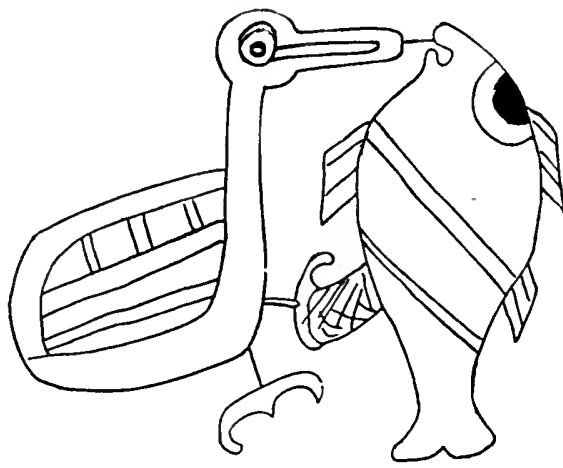

FIG. 59.-Bird carrying a fish outlined on shallow plaque found in Mound No. 17. of the Rio Hondo, where stone bass abound, is a favorite fishing ground for sea hawks and frigate birds.

(c) A number of painted and glazed potsherds of all sizes.

Beneath this second chamber a third was discovered, roofed in with rough flags, of the same dimensions as the other two. The floor of this chamber was cemented over; nothing except limestone blocks and mortar was found between it and the bottom of the mound. Upon the floor lay a solitary plaque, of a deep reddish-yellow color, the upper surface divided by black lines into four equal spaces, in each of which was erudely outlined in black a fish, probably meant to represent a stone bass. On digging into the summit of the mound outside the area occupied by the chambers, the following objects were brought to light: (a) A cylindrical vase of light, thin, well-made pottery, $16 \frac{1}{2} \mathrm{~cm}$. high by $13 \mathrm{~cm}$. in diameter, painted light yellow throughout and finely polished (fig. 60). Upon one side of the vase, within an oblong space outlined in black, are a number of curious mythological animals, above which is a row of six glyphs, seemingly explanatory of the picture beneath (pl. 19,a). Both animals and glyphs are very carefully executed in red, black, and brown, on a yellow background. The lowest figure on the right somewhat resembles that on a vase in the American Museum of Natural History, ${ }^{1}$ upon which the Longnosed god is associated with bulblike objects, flowers, and a bird (probably a pelican). On this vase the Long-nosed god is seen with a bulblike object, possibly a root, from which project interlacing stalks, at the

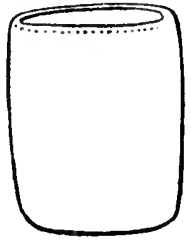

Fig. 60.-Cylindrical pottery rase found in Iound No. 17. ends of which are water-lily buds. Above these is a bird, possibly a sea hawk. The whole connotes water, or fertility. (b) A second vase, similar in shape, but somewhat larger (fig. 61), is painted rollow and polished throughout. Upon this is depieted a cruciform object, with outgrowths from the upper and lateral limbs of the 


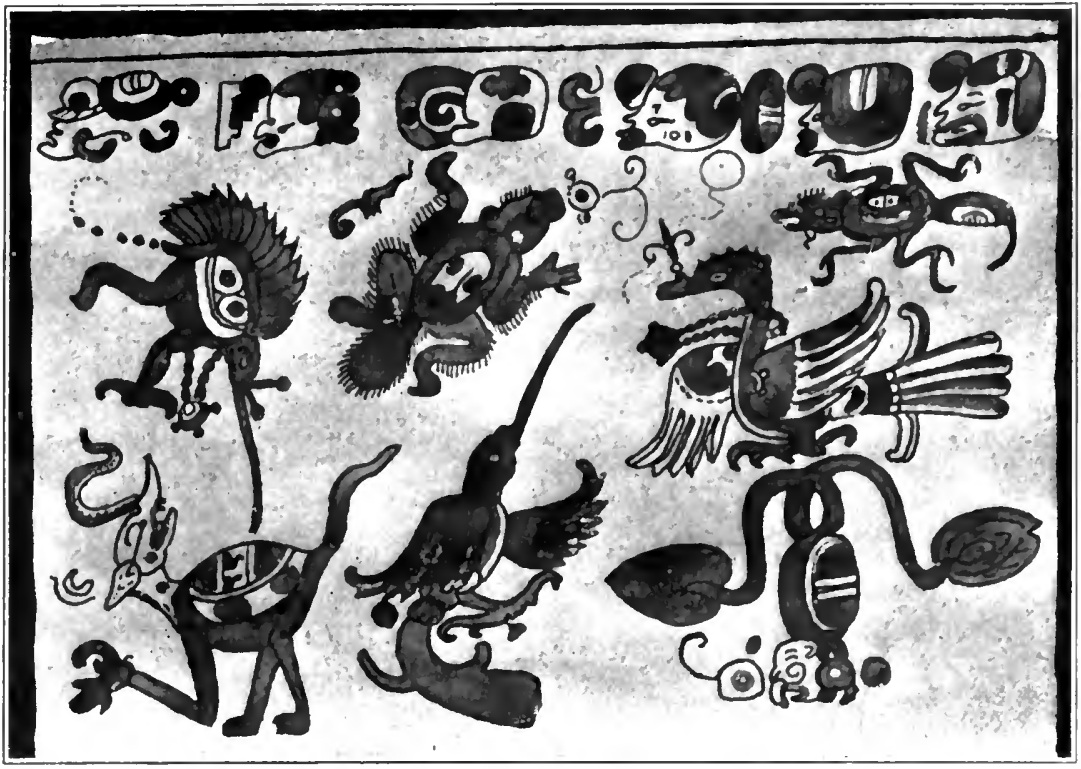

a. DECORATION ON VASE SHOWN IN FIGURE 60

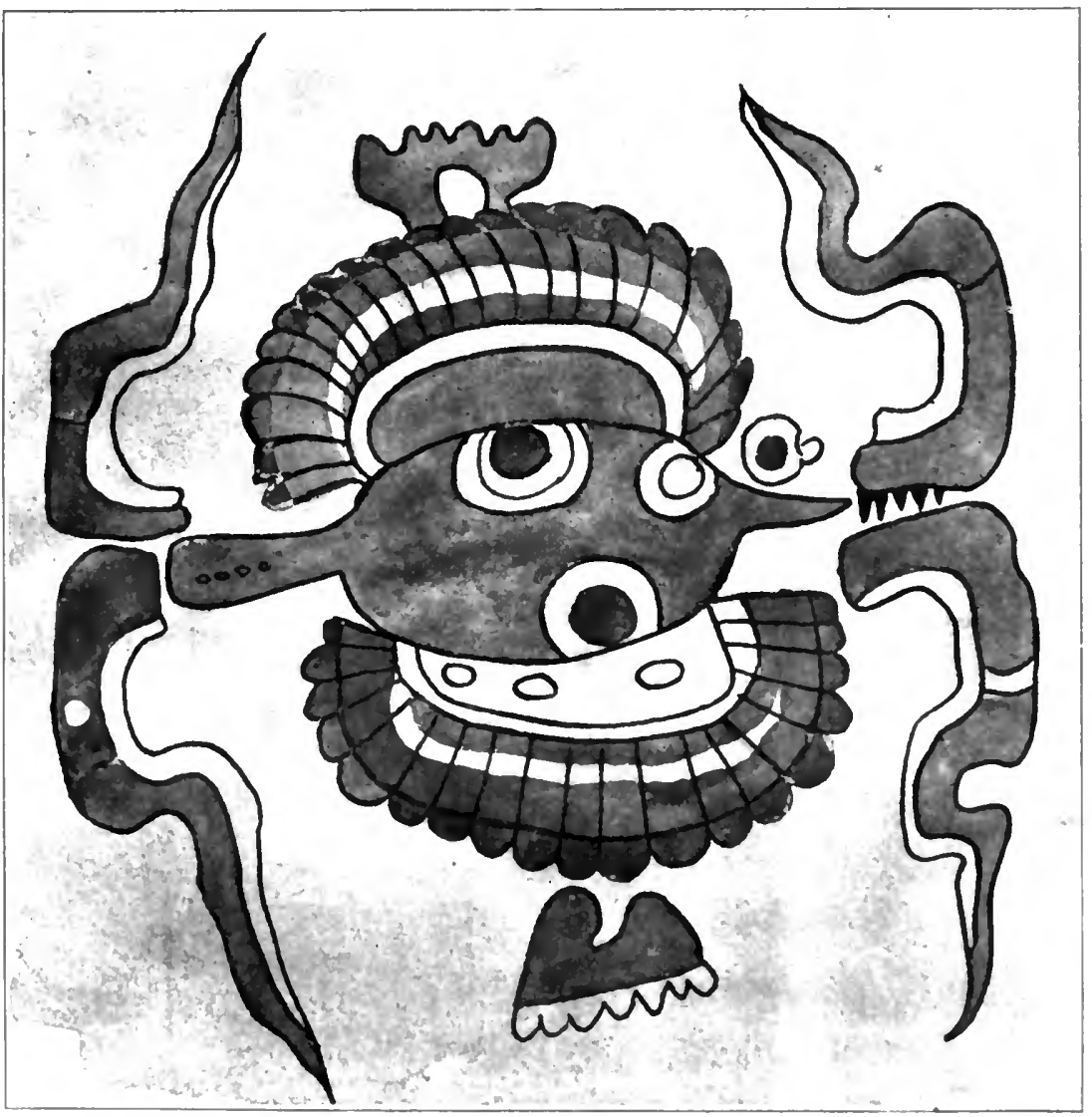



cross, probably a highly conventionalized tree. (c) A shallow circular plaque, $36 \mathrm{~cm}$. in diameter, painted light yellow, and polished throughout. Upon its upper surface is painted, in red and black, a coiled plumed serpent (fig. 62), doubtless intended to represent Cuculcan, the "Feathered Serpent." (d) Two circular objects of polished greenstone, somewhat resembling broad-brimmed hats from which the crowns have been remored (see fig. $57, b$ ). Each has on the upper surface of the brim a small ovate piece of mother-of-pearl, firmly cemented to the stone. These objects were probably used as ear plugs; with them were five small perforated spherical beads of polished greenstone.

At the base of the northern aspect of this mound was a small square enclosure, surrounded by a stone wall 2 to 3 feet in height. On digging into this, near its center, an alligator made of rough pottery, 15 inches long, was discovered. In the center of its back is a small circular opening, covered by a conical stop-

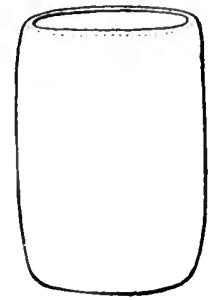

Ficr. 61. - Jarger pottery rase found in Mound No. 17. per, leading into the hollow interior, in which was found a small perforated polished jadeite bead, in the form of a grotesque human face. Close to the alligator lay a basin-shaped ressel, $28 \mathrm{~cm}$. in diameter, painted yellow, and polished throughout. In the renter of this, outlined in thin black lines, is the object seen in plate $19, b$,

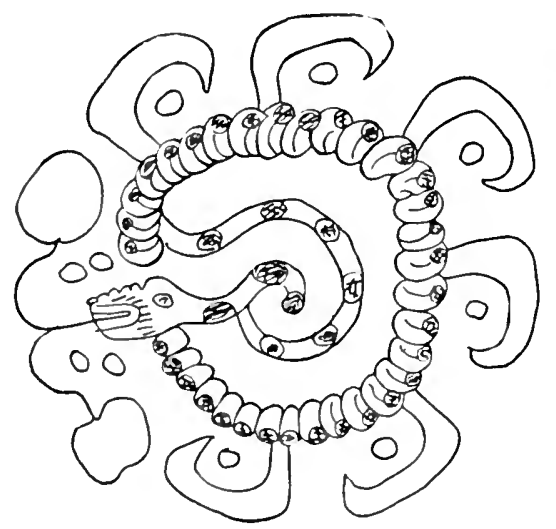

lisi.62.- roiled plumed serpent painced on plaquo found in Mound No. 17. probably meant to represent the two-headed dragon so common in Maya art.

\section{Moring No. 18}

Mound No.18, situated less than half a mile from the next preceding, was 10 foet high, 70 fect in circumference, roughly conical in shape, and firmly built throughout of blocks of limestone the interstiess between which wore filled with earth and limestone dust. It the bottom of the mound, near its center, resting on the sround, was a cist, about 2 feet in diameter, roughly constructed of larere flangs of limestone. Within this were found two vesicels: (a) 1 ba-in-shaped specimen of thin pottery, painted reddish-yellow and polished throughout; on its imnor surf alee is depleted, in fine black lines, an object closely recombling a four-leafod shamrock. (b) A vase of the shape shown in figure 63, 1:3 am. high and $13 \mathrm{~cm}$. in diameter. This is made of rather thick pottery: it is 
painted light yellow and polished throughout. On the outer surface of the rim, outlined in thin black lines, is the glyph represented in figure 64, which is repeated all the way round the circum-

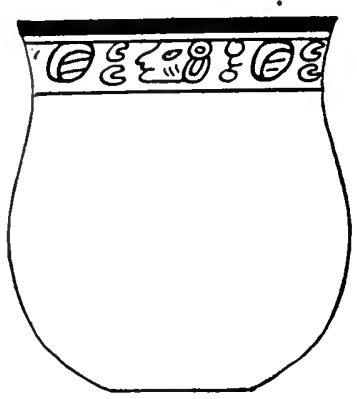

FIG. 63.-Pottery vase found in Mound No. 18.

ference. No additional objects were found in this cyst, nor were there any traces of bones in it, or in the rest of the mound, which was afterward examined.

\section{Mound No. 19}

Mound No.19, situated close to the preceding, was 6 feet in height, with flattened top, built solidly throughout of limestone blocks and a friable mortarlike substance. At the ground level, near the center of the mound, were discovered two cists, placed side by side, separated by a partition wall built of blocks of cut stone. Each cist was 6 feet long, 3 feet broad, nearly 4 feet deep, solidly constructed of stones mortared together. Neither the cists nor the body of the mound contained anything of interest except a few fragments of bone in the last stages of disintegration.

\section{Mound No. 20}

Mound No. 20 was situated at Pueblo Nuevo, about 6 miles from the mouth of the Rio Nuevo, in the morthern district of British Honduras. The mound was about 100 feet in length and varied from 8 to 12 feet in height and from 15 to 25 feet in breadth. It was built throughout of earth, limestone dust, and blocks of limestone, a great many of which had been squared. Immediately beneath the surface, ruming east and west along the long diameter of the mound and nearly centrally placed in it, was the upper surface of a wall, which had evidently at one time formed part of a building of considerable size. This wall was built of finely squared blocks of limestone mortared together, and was somewhat more than 18 inches thick. It extended for 40 feet, turning at right angles at both the eastern and western extremities and was broken by a

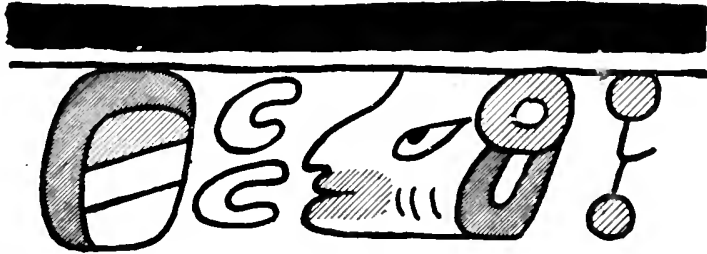

FIG. 64.-Gly ph outlined on outer surface of rim of rase shown in fig. 63. single opening, $3 \frac{1}{2}$ feet broad at the center. 'The part of the wall left standing varied from 2 to $3 \frac{1}{2}$ feet in height and was covered on its inner surface by a layer of smooth, yellow, very hard cement; the outer surface, which still retained traces of painted stucco moldings, 
ended below in a floor of hard cement 12 inches thick. The greater part of these moldings had been broken away, but portions were still alherent to the wall and great quantities of fragments, painted red and blue, were found immediately beneath the wall from which they had been broken. 'The most important of these were: (a) Two human torsos, one (the more elaborate) of which is seen in figure 65, $c$. (b) Three human heads, one of which is represented in figure $65, b$, in situ. Both heads and torsos are life size, and both are painted red and blue throughout. ${ }^{1}$ (c) 'Two headdresses, one of which is seen in situ in figure $65, a$; the other is almost preciscly similar in coloring and design. (d) Fraguents of elabo-

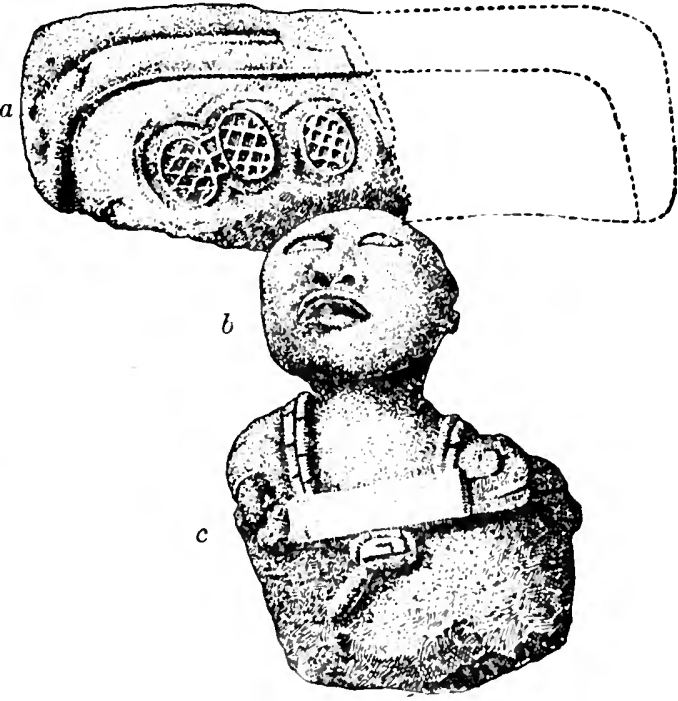

Fig. 65.-Torso, head, and headiless from Mound No. 20. rately molded pillars, which had originally separated the figures on the wall. A portion of one of these is shown in figure 66 . This drsign was repeated three times upon the front of the pillar, the back of which was flattened for attacliment to the wall. Great quantities of fragments of painted stuceo, of all shapes and sizes, were dug out of the mound, but the human figures, with the pillars which separated them, were the only objects the original

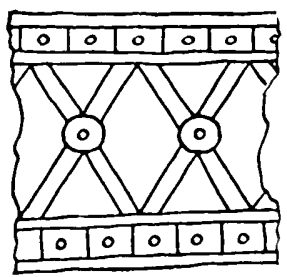

Fite fiti-Frigment of pillatr fomml in Momnal Vio. 2). positions of which on the wall it was possible to detemine with certainty. Resting upon the layer of haud (ement in which the wall terminated below, between 5 and 6 feet from the eastern and and rlose to the wall itself, was found an adult hunnan skeleton, the bones of which were huddled together within a very small compassis, in a manner sugrerest hing secondary burial. In removing these bones nearly all of them crumbled to pieres. Throughout the whole nomel were found numerous potsherds, some of very fine pottery, colored and polished; other's thick, rough, and underorated. Fragments of flint and obsidian, broken flint speartheads and scrapers, and broken obsidlian knives were also found.

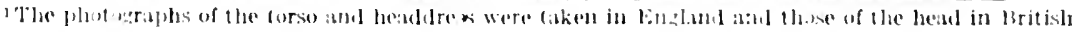

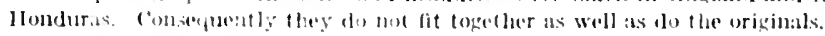

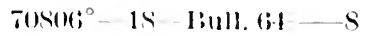




\section{Mound No. 21}

Mound No. 21 was situated near Corozal, in the northern district of British IIonduras. This mound had very steep sides; it was 50 feet in height by 200 feet in circumference, and was built of blocks of limestone, the interstices of which were filled with friable mortar. Toward the west the mound joined a smaller mound, 20 feet in height. A rumor was current among the Indians in the neighborhood that some years before a number of fragments of clay idols had been found lying on the surface of the earth near the mound. Excavations were consequently made all around the mound, for a distance of 10 to 15 yards from its base, through the alluvial soil, down to the limestone rock, a distance of 6 inches to 2 feet. These excavations brought to light enormous quantities of fragments of crude, coarse pottery ressels, for the greater part the remains of large hourglass-shaped incense burners, which had been decorated on their outer surfaces with either a human head or an entire human figure. Among these fragments were animal heads in terra cotta, tho snake and the dragon being of most frequent occurrence, but the deer, alligator, and tiger also being represented. IIeads of the owl, the wild turkey, and the humming bird likewise were found. Fragments of about a dozen human faces were brought to light, with the usual nose ornaments, large round earrings, and labrets. Quilted cotton, stud decorated breastplates, sandaled feet, and bracelet-decorated hands and arms were also plentiful. The right arm seems in most cases to have boen extendod, holding in the upward turned palm some object as a gift or offering. These ohjects vary considerably; three are undoubtedly wild turkeys, -with their long necks coiled around their bodies; two are palm-leaf fans attached to handles; one appears to be a shallow saucer containing three small cakes; while two are pyramilal, spike-corered objects, possibly meant to represent the fruit of the pitaya cactus. With these fragments of pottery were found four entire oval pottery vases, each about 4 inches high, standing on threo short legs, each containing a fow clay and polished greenstono beads. Close to these was a pair of rases, shaped like a right and left foot and leg, of the size approximately of those of a child 7 or 8 yoars of age, greatly expanded abore the ankle. These vases showed trices of white and blue paint, which hal, howevor, almost completely worn off; around them were a considerable number of fragments of the bones of deer and peccary, very much docayed. Close to tho base of the mound was found an oval block of limestone, which formed the nucleus of a small hill, 2 to 3 feet high and 5 to 6 feet in dimmeter, composed almost entirely of pottery fragments, with a capping of humus. It is not improbahlo that this was the spot on which tiro ceremonial dustruction of those 
incense burners took place, the fragments being scattered in all directions around the entire circumference of the large mound.

\section{Mound No. 22}

Mound No. 22, situated at Saltillo, near the mouth of the Rio Nuero, northern district of British IIonchuras, was partially explored it 1908 -9 on behalf of the Institute of Archæology of Liverpool University. The mound was about 30 feet high; it was built of limestone blocks, limestone dust, and rubble. It stands at one comer of a quadrangular space measuring 80 by 35 yards, and el:vated from 4 to 5 fert above the surrounding ground lerel. This spaeo is encompassed by four mounds, joined by a bank or rampart averaging 10 feet high. Around the base of the mound a great number of fragments of pottery incense burners were found, with the images of the gods, which decorated them externally. Eight complete heads and two broken ones were recorered, together with arms, legs, hodies with quilted cotton breastplates and maxilis, elaborate headdresses, and various objects held in tho hands of the figures. These vessels are almost exactly similar to those found along the valley of the Isumasintla and Rio de la Pasion, described by Seler in his "Antiquities of Cuatemala." Rule specimens, with the face of the god only decorating the outside of the vessel, were found by Sapper and Chamay in uso among the Lacandon Indians a fow years ago. The dress and ornaments of theso clay figurines, which vary from 1 to 2 feect in height, are those found almost universally throughout the Maya area. 'The largo circular ear ornaments, with a tassel or twisted pendant hanging from the center, the curious projerting curvel ormannent above the nose, the small button-like labrets at. anch cornere of the mouth, are present in all, and are highly characteristic. On all the feet alaborate sandals are worn, fastened by thongs attached between tho lirst and second and third and fourth tores, with a band pasingr around the ankle ending in a broad depend"nit flap. Around the leges aro plain bands and stringes of beadi: around the wrists, strings of beals, in somo cases fastened by an ormamental loop. Tho breant plates aro of quilted cotton, some rery claborates, and decorated with beads, studs, and tassels, whito betow the breastplate covering the grenitals is the maxtli, or smatl apron. commonly worn by both Maya and Azter. The objects held in the hamdis consist of birds, fans, grobes, incense burners, and of her lesis abily distinguishahle articles. The whole of the space within the arthwork appears to have boen sprinklad with these fragments of pertery valses and idlols, but it was only around the haso of the larene

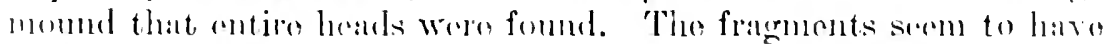

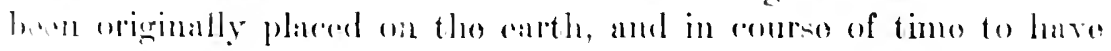
been covored by a thin layer of humus from decaying romation, 
as many of them still lie on the surface, and nowhere are they buried more than a fow inches, except at the base of the mound, where earth from its side, washed down by rains, would naturally have covered them with a slightly deeper layer. On making excavations at various points within the enclosed space, the floor was found to consist first of the earth which contained the broken incense burners, with some blocks of limestone, and beneath this of a layer about 4 foet thick composed of marl dust, very small fragments of pottery, and rubble, welded together into an almost cement-like mass.

\section{Mound No. 23}

Mound No. 23 was situated near tho northern end of Chetumal Bay, on the east coast of Yueatan. The mound was 12 feet in height, roughly circular in shape, and 12 yards in diameter at the base. The top was flattened, and near its center a circular space 10 foet in diameter was inclosed by a low, roughly built stone wall. On digging within this space there were brought to light, immediately beneath the surface, the following objects:

(a) Part of a large hourglass-shaped incense burner in rough pottery, decorated with a human figure in high relief, 20 inches high. Unfortunately the left arm and log and part of the chest are missing from this figure, which, judging by the headdress, curved nose, and tusk-like teeth, is probably intended to represent the God Cuculcan. The left foot is sandaled, and on the left wrist is a loop-fastened string of beads, while over the front of the ehest hangs a breastplate of quilted cotton, decorated with flaps and fastened over the shoulders. ${ }^{1}$ Round the neck is a flat gorget, decorated with round bosses, and in the ears are large circular ear plugs with tassels dependent from their center's. Orer the upper part of the nose is a curious curved, snako-like ornament. The lofty headdress, with broad flaps extending over each ear almost to the shoulders, has in front the head and upper jaw of some mythological animal, the latter projecting woll. over the face of the god, as if in the act of swallowing him. Pointing downwarl from the plumed ornament on the right side of the figure (the corresponding one on the left has been broken away) is a crotalus head, which so often accompanies representations of this god. The figure still exhibits traces of blue and white paint on that part of the face protected by the broad flap of the headdress, and originally doubtless the whole was painted in rarious colors, which first exposure to rain and aftemward burial in moist earth, have almost completely obliterated. (b) An earthenware figure, 26 inches in

\footnotetext{
1 It would alpear that these thick woven or plaited eot ton breastplates were fortified with salt.

Landa, op. cit., p. 4 : "Y sus rodelas y iuc'os fuertes de sal y algodon."

Ibid. 1" 172: "I [azian xacos de algodon colchados $\mathrm{y}$ de sal por moler eolchada de dos tandas ocolehaduras, y estos eran fortissimos."
} 
height, which doubtless at one time ornamented the outer surface of a large incense burner. The left foot and leg are gone; the right foot is covered with a sandal held on by a curved heelpiece rising above the back of the ankle, and fastened in a bow in front of the instop, while a leather thong passing between the great and second toe is attached to this, holding the front part of the sandal in place. Round the leg is a broad band, with a row of semilunar ornaments projecting downward from it. The maxtli has been broken away, but the quilted cotton chest covering is still in position. This is held in place by bands passing orer the shouklers, and is ornamented by a row of five circular studs passing down its center, with long tassels below, which must have hung on each side of the maxtli, and tassels above, attached near the shoulder, which hang down on each side of it. The throat is covered by a broad band, decorated along its lower edge with four pairs of small circular studs. Round the left wrist is a bracelet composed of six flat oval beads, fastened in front- by an ornamental loop. The left arm is extended, and in the hand, held palm upward, is grasped an acom-shaped object from winich project nino spikes. From each side of the mouth project long curved tusks. The nose is of unusual shape, being long, straight, and slender; the bridge is covered by a curved snakelike object. The headdress rises 6 inches above the superciliary rideres: its lower part consists of the head and upper mandible of the bill of some bird, probubly a hawk or eagle. Abore this rises a hollow cylindrical erection, with the upper border scalloped, supportad on each side by objects which suggest broad stone blades, hafted in club-shaped handles, and ornamented in front with a plume of feathers. There can be little doubt that this figure is meant to represent the God Itzamni, as the sunken cheeks, the single large tooth on each side of the mouth, and the prominent, though well-formed nose, are all characteristics of this god. (c) An earthenware figure, elosely similar in size and appearance to those just described. Of the face only the left eye, the left side of the mouth, and the nose are left; the last named is short, rounded, and well formed, and is ornamented at its root with a small round stud. (d) Fragments of a rough bowl of yellowish pottery, which must have beon of considerable size. Unfortunately only four framents were found: these exhibit on their outer surfaces parts of a hieroerlyphic inseription, roughly incised in the daly while it was soft, with some sharp-pointed instrument. Of the many gryphe inseriptions which have been fonnd at diflerent times in British Honduris, painted on pottery and stuceo and incised on pottery, stone, and other material, none has prored to be an initial series, which would fix the period in the May a longreount when the mounds, temples, burial places, and other monuments scattered throughout this 
colony, were constructed. According to recent researches the latest date recorded by an initial series on the monoliths of Quirigua, in Guatemala, is within about 70 years of the earliest date recorded by any of the initial series found up to the present among the ruins of Yucatan. ${ }^{1}$ As the tide of Maya migration was undoubtedly from south to north, and as British Honduras stands midway between Guatemala and Yucatan, it is only reasonable to suppose that the colonization of the greater part of it by the Maya took place at some period between the abandonment of the cities of Quirigua and Coban, and the rise of Chichen Itza, Uxmal, and other Yucatan cities. This theory is borne out by the fact that the hieroglyphie inscriptions and pictographs found in the colony are closely allied to those found both in the northern and southern cities; moreover, the painted stucco and wooden lintels so common in Yucatan, but not found in the south, are present here, while the sculptured stelæ found in the south, but of extreme rarity in northern Yucatan, are (though not very numerous and poorly executed) found in British Honduras. (e) Large quantities of fragments of rough pottery vases and bowls; some of these evidently belonged to hourglass-shaped incense burners, 2 to 3 feet high, decorated with incised lines and glyphs, raised bands, and studs, but without human figures on their exterior surfaces. A number of these fragments were taken down to the camp of some chicle bleeders in the vicinity; unfortunately in the night the palm-leaf shelters caught fire and the whole camp was burned to the ground, most of the potsherds being lost or destroyed. Among these were probably the missing parts of the clay figures and of the hieroglyphic-covered pot. The whole of the mound was dug down, but with the exception of traces of a wall built of squared stones on the ground level, nothing worthy of note was found in it. It is almost certain that this mound had never been risited from the time of its erection till its discovery last year by chicle bleeders looking for sapodilla trees in this very remote corner of Yucatan. The clay images were lying on the top of the mound, partially uncovered, and had anyone, even an Indian, visited the place, they would almost certainly have removed these, as there is always a ready market for $i d o l o s$, as the Indians call every relic of their ancestors, among curio collectors who visit Belize.

\section{Mound No. 24}

Mound No. 24 was situated near the coast, at the northern extremity of Chetumal Bay, in Yucatan. This mound was 10 feet high by about 10 yards in diameter. Upon the summit, which was flattened, were found a great number of rough potsherds, partially buried in a layer of humus from 6 to 12 inches deep. These were evi- 



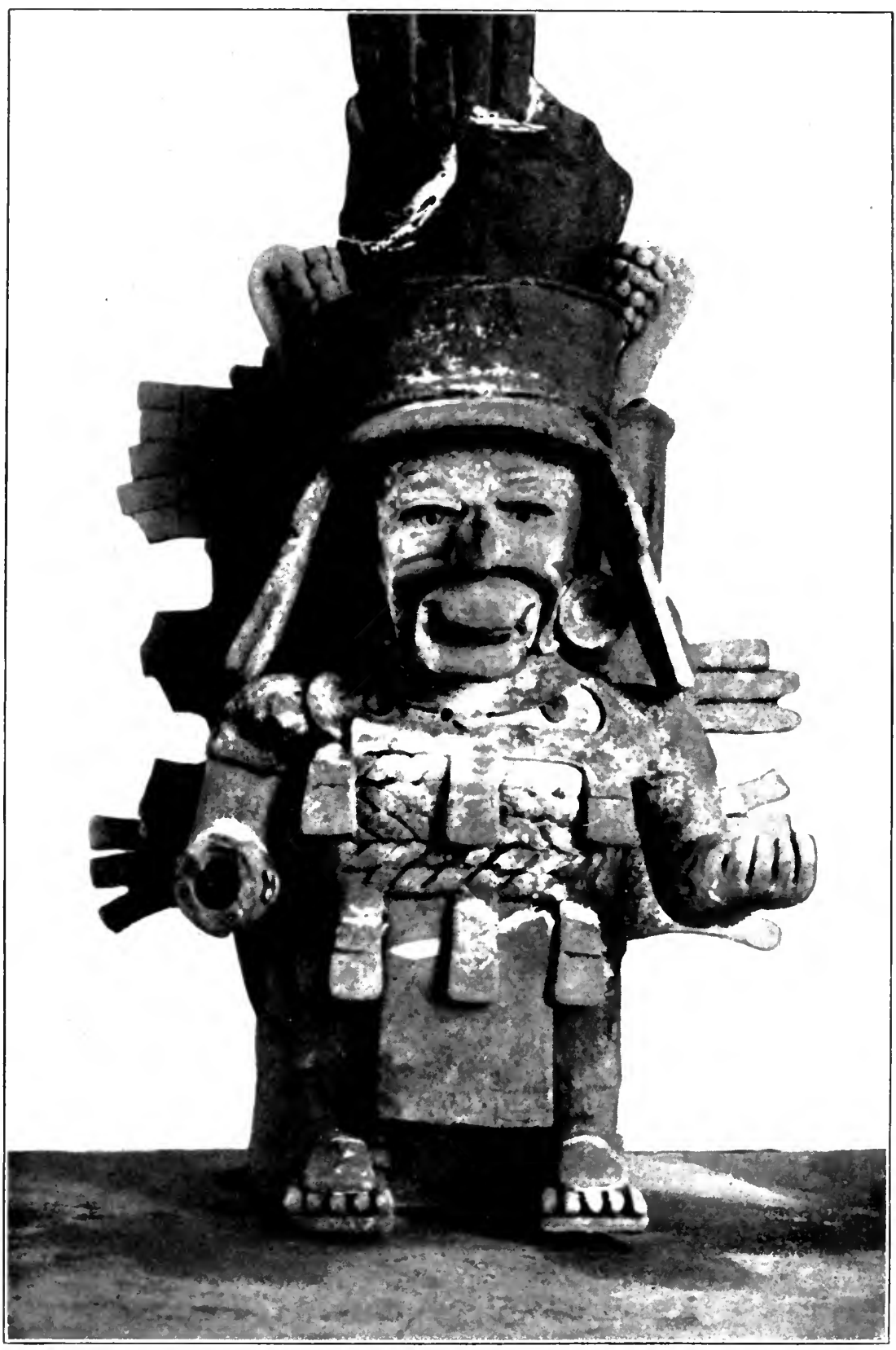

INCENSE BURNER FROM MOUND NO. 24 
dently fragments of incenso burners, as arms, legs, and parts of headdresses, faces, maxtlis, and breastplates were plentiful among them. Near the center of the summit, partially projecting from the earth, was discovered the almost complete incense burner shown in plate 20 and figure 67 . The vessel which served as a receptacle for the incense is $15 \frac{1}{2}$ inches high by 9 inches in diameter at the mouth. The human figure which decorates the side of the vessel is 22 inches in height from the top of the headdress to the sole of the sandals. The figurine was not eomplete when first discovered, as the hands, arms, feet, maxtli, and feather ornaments from the sides and headdress were missing; nearly all of these, however, were unearthed, mixed with other pieces of pottery, not far from the incense burner. The headdress consists of a flat, broad cap with slightly projecting rim and large quadrangular flaps, which extend downward and outward over the large ear plugs. The back of the cap extends upward 3 inches; the crown is decorated with feather ornaments, while on each side appears an object resembling half an ear of maize, from the top of which depends'a tassel. The nose is sharp, thin, and prominent; starting on each side of it and passing down almost to the angles of the jaw, where it ends in a little upward curl, is what might be intended as cither a mustache or some form of nose ornament. From each angle of the mouth projects a circular labret; this avidently passes behind the upper lip, which it causes to bulge considerably. The ear plugs are large, round, and funnel-shaped (pl. 20); these, as well as the shoulders, show traces of blue paint, with which the entire figure

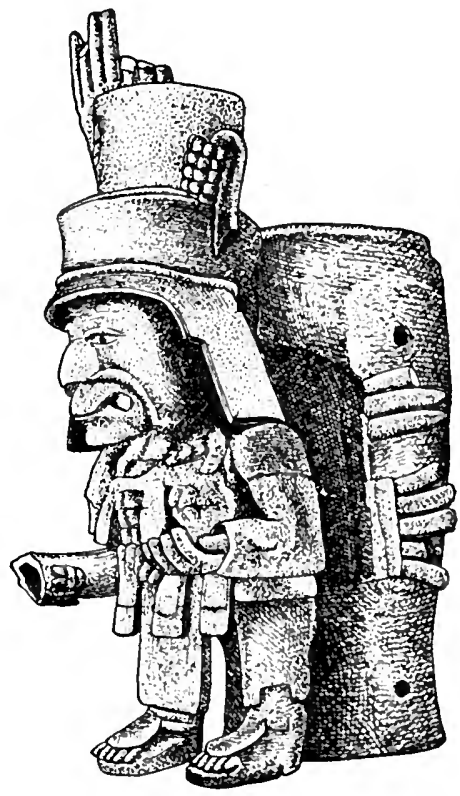

F19. 67.-A nother view of incense burner shwn in plate 20.

was evidently at one time covered. Around the neck is a flat collar decorated with five circular studs, to the sides and front of which is at ached a hollow eylindrical bar, which supports the quilted cotton breastplate. 'The latter is decorated with six tassols, three abore and three below, and below it is seen the pluin apron (maxtli), which descrends almost to the sandals. The shoulders are covered with caps or epaulets reaching just below the armpits; on the forearms are braxelets, fastened with loops on the inner side, and on the feet sandals, hedd in place by vertical heolpieres and thonges, and decorated with large flaps, which almost cover the dorsum of each foot. Attached 
to the incense burner, and forming a background for the figure, are projecting feather ornaments extending from the headdress to the elbow.

The mound was dug away to the ground level. It was found to be built of blocks of limestone and earth, but nothing of moment was fourd in it with the exception of numerous potsherds of all kinds.

\section{Mound No. 25}

Mound No. 25 was situated in the country of the Icaichè Indians, Quintana Roo, Yucatan. The mound was discovered by the Indians when entting down virgin bush to make a milpa, or corn plantation.

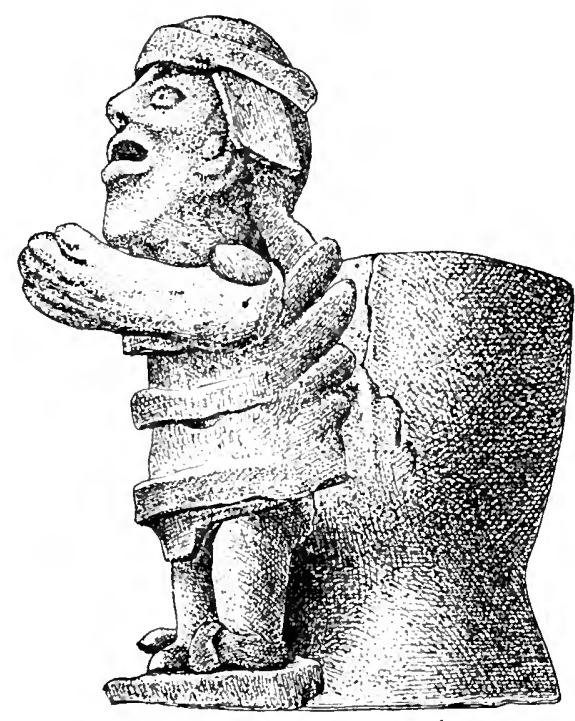
Fig. 68.-Incense burner decorated with crude clay them, the liorizontally striated figurine from MIound No. 25. about 10 feet high, and upon its summit, uncorered, lay the objects illustrated in figures $6 \mathrm{~s}, 69$, and 70. Figure 68 exhibits a roughly formed clay figurine, nearly 1 foot in height, decoriting a small hourglass-shaped incense burner. Both figure and rase are very crudely modeled in rough pottery ; most of the prominent characteristics of the carefully modeled and elaboristely decorated incense burner represented in plate 20 and figure 67 are still retained. 'The large round ear plugs, with long flims from the headdress orerlapping

It was a moderate-sized mound, breastplate, and eren a rudimentary maxtli, together with the extended position of the arms, as if in the act of making an offering,and the background of fea therwork arefea tures which may be recognized. 'There is exhibited, however, a lamen table decarlence from the art which fabricated the more elaborat te rase. In figure 69 may be seen what probably represents a further stage of degeneration-namely, the sulsstitution of the head for the entire figure on the outside of the incense burner. The last stage of all in the decadence of this branch of Maya art is to be seen in the small crude bowls found by Sapper in the great Christa of the settlement of Izan, and by Charnaly in the ruins of Menche Tinamit. ${ }^{1}$ These bowls,

1 . Account s the finding of these incense burners and of copal are common in both ancient and modern

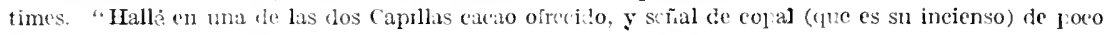
tiempo allí quemado, y que lo era de alcuna supersticion, ó idolatria recién cometida. "-CogoluUno, Historia de lucathan, lik. Iv, Cap. vir, p. $1: 3$.

"Y los que ivan tenían de costumbre de entrar también en templos derelictos, quando passavan por ellos a orar y (Iuemar copal." -LANUA, op). cit., p. 1.s. 
each decorated with a roughly modeled human face, are manufinctured by the modern Indians and used by them in burning copal gum in the ruins of the temples erected by their ancestors. Figure 70 shows a life-sized hollow head, in rough pottery, with a thin hollow neck, probably used to carry aronnd in processions on the top of a long pole. There can be no doubt that these bowts and hourglass-shaped ressels, each decorated externally with a human figure or face, usually that of a gorl, were used as incense burners, since a number of them, as already stated, were found in a mound at Sintal Rita with half burnt out incense still contained in them. Moreover, their use for this purpose persists to the present day amoung the Lacandones ${ }^{1}$ and even among the Santa Cruz Indians. These incense burners orcur most frequently in the central part of the Maya area and are not cominon in northorn Yueatan or southern Guatemala. Three distinct types are found: The first include the large, well-modeled specimens found in and around burlal mounds, decorated with the complete ligure of the god (usually ('urulain or Itzamma), having every detail in elothing and ormament curefully executed in high relief. 'These are all probably pre-Columbian, and such as

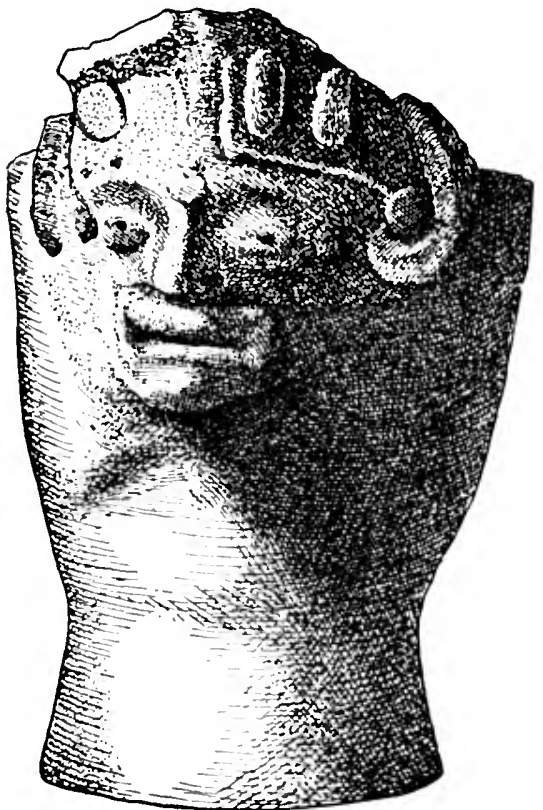

Fig. 6:?-C 'rinde ciay ligurine fouml in Mund No. 25. have been found seem to have been used only as ceremonial morthily incense burners, to be broken into fragments (which were seattered through or over the burial mound) immediately after use.

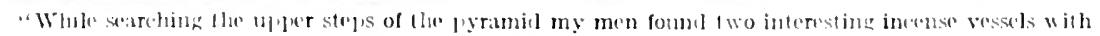

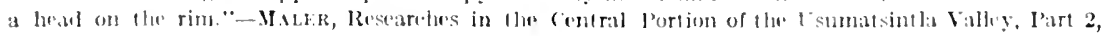
p. I3ti.

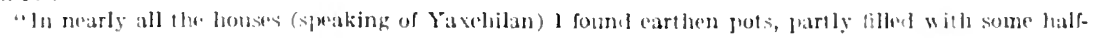

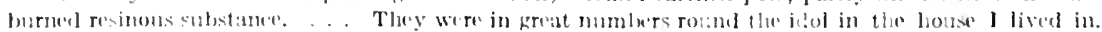

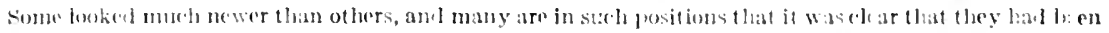

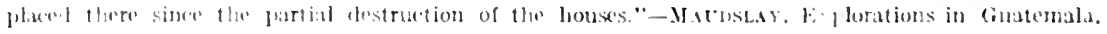
1'i). 121.

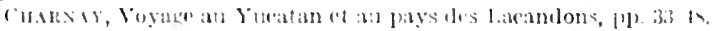

".

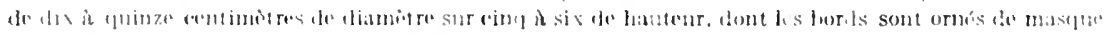

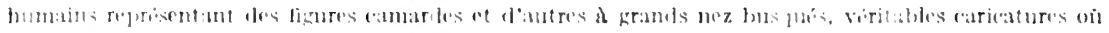

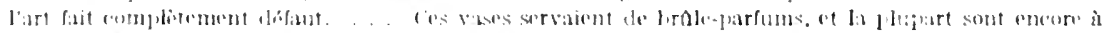

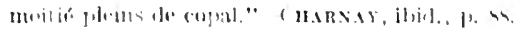

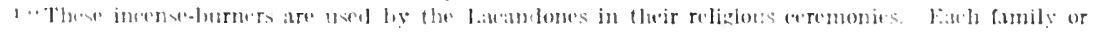

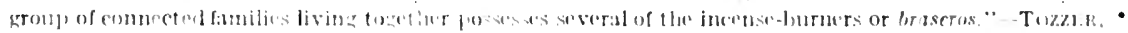

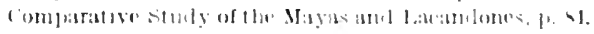


The specimen shown in plate 20 and figure 67 is a typical example of this class.

Incense burners of the second type are smaller, eruder, and probably later in date than those of the first type. Some of these are decorated with the entire figure, but more of them with the face only of the god.

Villagutierre tells us that the Indians of this region as late as the end of the seventeenth century still practiced to some extent the rites of their ancient religion $;^{1}$ and in the royages which he describes

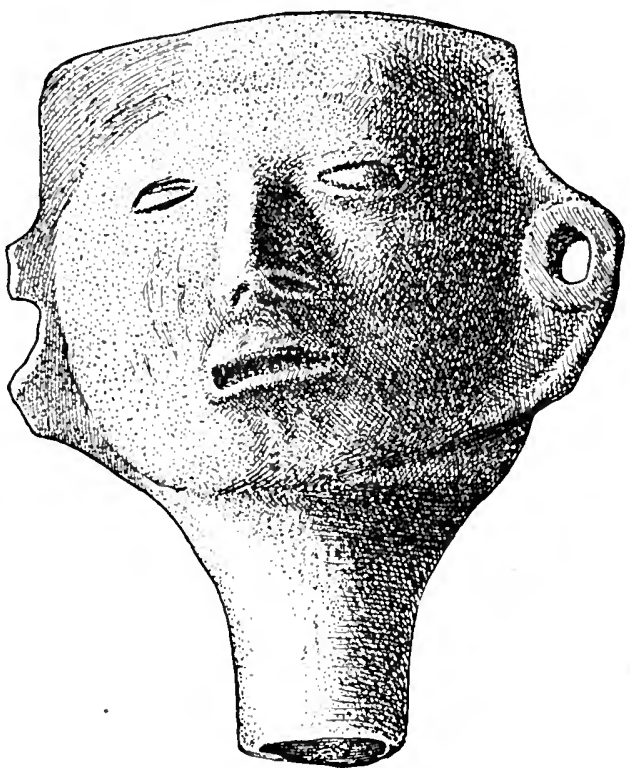

FIG. 70.-Crude elay figurine found in Mound No. 25. up the Rio Hondo, and to Tipu, the Spaniards must frequently have come in contact with the ancestors of the present Santa Cruz and Icaichè Indians, from whose territory the specimens shown in figures 68 and 69 , typical examples of this class, were taken. During the early years of the Spanish occupancy it is probable that the Indians, even in this remote and little visited region, living in a constant state of semiwarfare and rebellion, robbed, enslaved, driven from their villages, with little time to cultirate their milpas, gradually lost their ancient traditions and arts, and, long neglecting, ultimately almost entirely forgot, the elaborate ritual connected with their former religion. Such a decadence may be observed in comparing the incense burners illustrated in plate 20 and figure 68 . The very marked facial characteristics of the former have given place to the crudely modeled, vacuous face of the latter, resembling the work of a child; while the claborate dress and ornament, each minutest part of which probably had a special significance and symbolism, though retaining to some extent the form of their main constituents-the headdress, breastplate, maxtli, and sandalshave almost completely lost the wealth of detail which gave them significance.

1 "Y las dos mas grandes, de Comunidad, y la otra, aùn mas grande, que todas las ot ras, era el Adoratorio de los perversos Idolos de aquellos Lacandones, donde se hallaroa intehos de ellos, de formas raras, como assimismo eant idad de Gallinas muertas, lirasseros, con señales de a:er quemado Copal; y aù se hallaron las cenizas calientes, $y$ otras diversas, ridiculas, $y$ abominables cosas, pertenecientes a la execieuion de sus perversos Ritos, y Sacrificios."-VhllagutierRE, op. cit., p. 264. 
Incense burners of the third type are decorated with a rery crude representation of the face only of the god, consisting in some cases merely of slits for the eyes and mouth, with a conical projection for the nose, on the outer surface of the vessel. Some of the faces are represented conventionally by two ears, with ear plugs, one on each side of the vessel, or by knobs of clay on its outer edge, which represent the hair. Lastly, the incense burner, which may be recognized by its hourglass shape, may be quite plain and undecorated.

The third type is probably the latest in point of time; ${ }^{1}$ this includes the erude face-decorated bowls still used by the modern Lacandones, ${ }^{2}$ among whom the ritual, as is so frequently the case, seems to have survived almost in its. entirety the faith which gave birth to it. This is the more readily comprehensible when we remember that the manufacture and use of these ceremonial incense burners was practiced commonly by all classes of the people, not having been restricted, like most other details of the Maya ritual, solely to the priests.
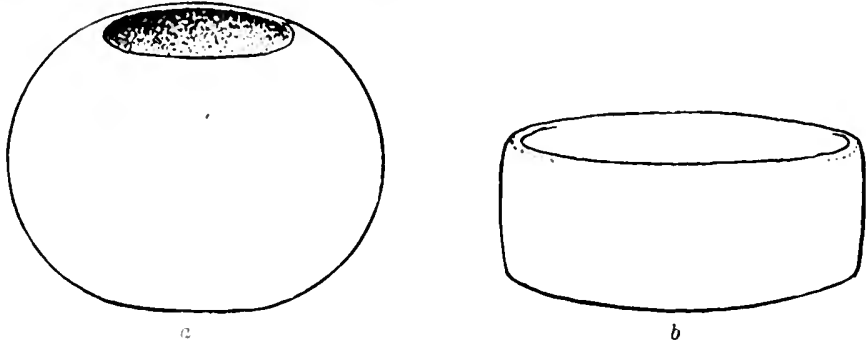

Fiti. 7t.-Small pottery vases fonnd in Mound No. 2t.

\section{Mound No. 26}

Mound No. 26 was situnted in a clearing about 7 miles to the south of Corozal, in the northern part of British Honduras. There were about 20 mounds, irregularly grouped, in this clearing, varying from 6 to 12 feet in height and from 50 to 120 fect in circumference. The nomal was 8 feet high by so feet in circumference. It was built of roughl blocks of limestence, limestone dust, and earth, tightly packed

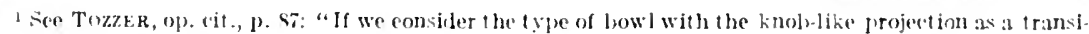
tion form, we are ford to the conclusion that the most firmitive form of incense hurner was the bowl on

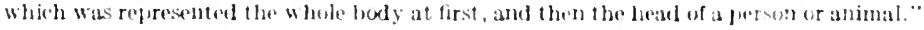

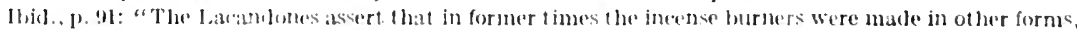
somo pessessing arms and lewt. 'These are seldom made or uxed new."

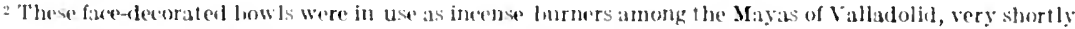

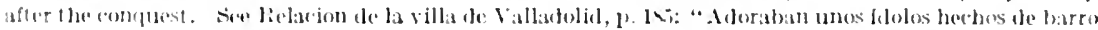

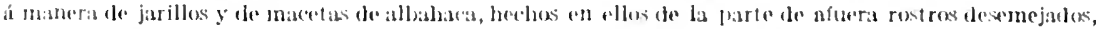

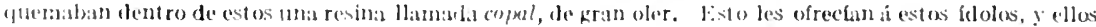

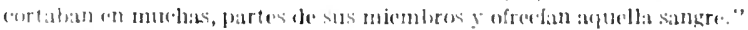

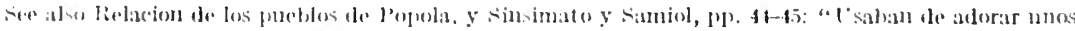

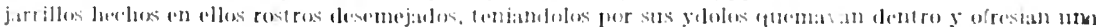

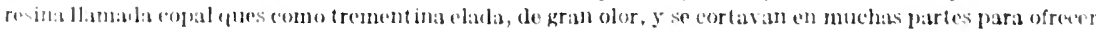
las situger a aguel ydolo." 
together, forming a tough, resistant mass. The mound was completely removed to the ground level, but nothing of interest except chips of flint, fragments of obsidian knives, and potsherds was found till the ground level was reached. Lying upon this, near the eenter of the mound, were found the two small vases represented in figure $71, a, b$. Each is about 6 inches in diameter; the one marked $a$ is of polished red pottery, nearly globular in shape; $b$ is of dark chocolinte-colored pottery, also finely polished. There was a space of about 4 fect between the two vessels, in which were found fragments of human bones.

\section{Mound No. 27}

Mound No. 27 was situated within 100 yards of the next preceding, compared with which it was slightly smaller. It was built of blocks of limestone, limestone dust, and earth. No remains were found in the mound till the ground level was reached. Resting on this, about the eenter of the mound, lay a small vase

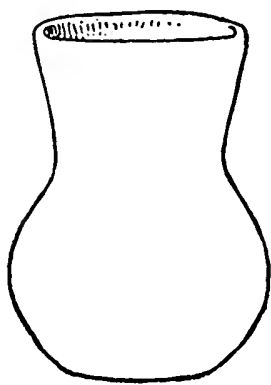

FIG. 72.- Red pottery vase found in Mound No. 27 . (fig. 72), 8 inches in height, of rough red pottery. Close to this were a few fragments of human bones and some tecth. This mound contained nothing else of interest.

\section{Mound No. 28}

Mound No. 28 wis situated close to Nos. 26 and 27 , and was built of similar material. It was 6 feet high by 120 fect in circumference. On the ground level about the center of the mound lay a circular, flat-bottomed bowl 8 inches in diameter, painted a darkchocolate eolorand polished. A hole had been bored in its bottom and the bowl itself was broken into three pieces. With it was an irregularly shaped piece of flint about 5 inches in length, into whieh nearly 20 cireular holes had been bored. It would appear that this piece of flint had been used to test the merits of various boring implements, as some of the holes were shallow depressions, while others were half an inch deep. Most of them were mere circular depressions of rarying diameters, with a smooth flat bottom, and had evidently been made with a solid cylindrical borer, others, however, had a solid core projecting from their bottom, and appeared to have been bored with a hollow cylinder; while a third variety had a small ind entation at the summit of this central eore. No further excaration was done in this group of mounds, as they all appeared to be sepulchral, belonging to persons of the poorer cliss, hence it was considered very improbable that objects of interest would be found in them. 



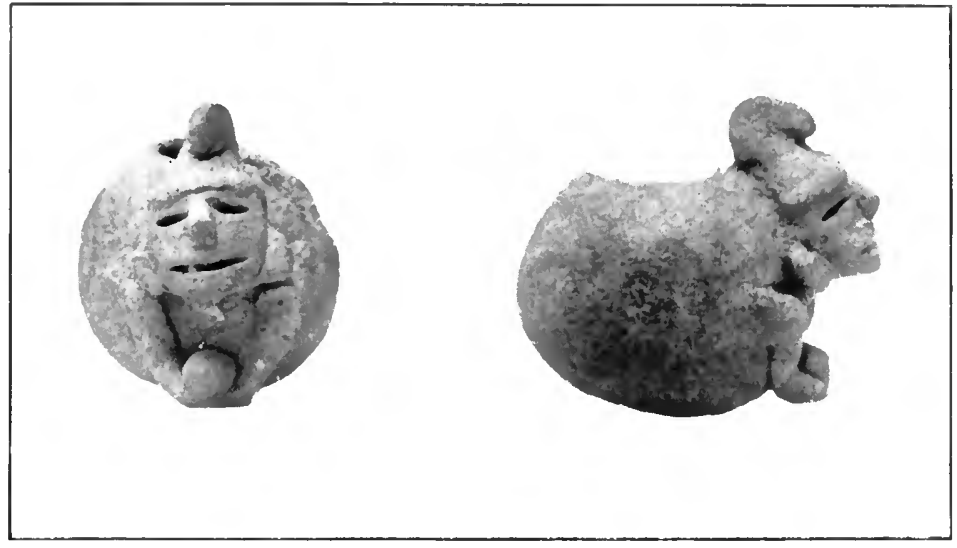

a. SMALL VASE DECORATED WITH HUMAN HEAD

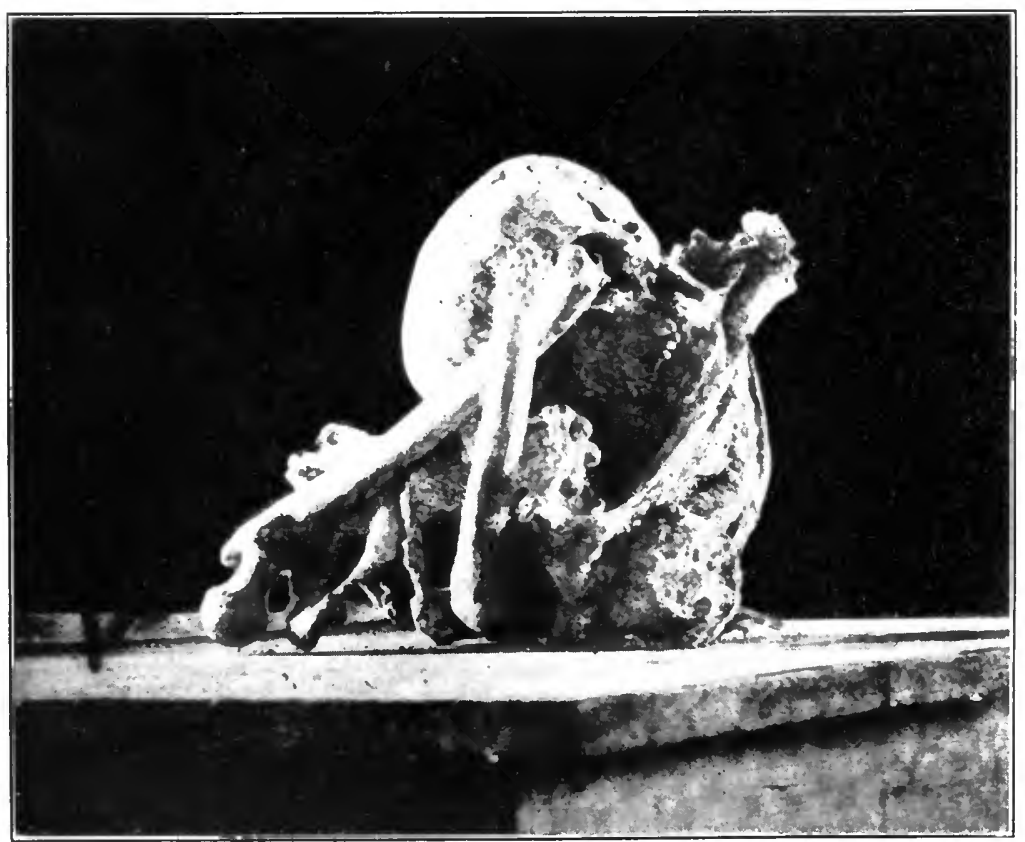

b. HUMAN BONES FROM MOUND NO. 29 


\section{Mound No. 29}

Mound No. 29, situated close to the seashore, near Corozal, was of unusual construction, being built throughout of marl dust. It was a low, flat mound, 2 foet in heirht by 25 feet in diameter. Nothing of human origin was found in it with the oxception of a few rough potsherds. On reaching the ground level two circular well-like holes, 2 feet in diameter, were discovered, about 15 feet apart. At the top both openings were covered with large blocks of limestone, on remoring which it was found that each hole was filled with marl dust, enclosing in both cases a singlo male human skeleton. 'The knees had been forcibyy flexed on the thighs, and the thighs on the pelvis, whilo tho back had been bent till the head, which rested on the folded arms, almost touched the symphysis pubis. Eridently the body had been doubled up at the time of burial, so as to fit tightly into the carity, and had been further compressed by ramming down large stones on top of the marl dust with which it was surrounded.' 'Tho bones in ono of the graves were in an excellent state of preservation, as may he sien from plate $21, b$; they are those of a young adult male, probably somowhat more than 5 feet in height, of poor muscular development. The teeth aro excellent; the skull is decidedly brachicephalie, the measurements being: Length, $15.4 \mathrm{~cm}$; breadth, $17.5 \mathrm{~cm}$.; circunferonce, $52 \mathrm{~cm}$; cephalic index, 113. Beneath this skeleton were found an unfinished flint arrowhead, four fragments of small obsidian knives, and the broken framents of a small, round, unpolished chocolate-colored howl.

'The bones in the other cist, though placed apparently uncler preciscly the same conditions as the one first opened, were found to be so friable that they crumbled into fragments when an efort was mado to renove them Beneath them were found only fragments of obsidian knives.

\section{Motxil No. 30}

Momed No. 30, situated close to Corozal, was completely dug down, and was found to contain multiple burials. The mound was s foet in height, roughly circular, and 40 feet in dianeter. It was calpped by a latere of reddish-brown earth, 6 inches to 1 foot in thickness, beneath which were alternate lavers of soft cement, each about 1 foot thick, and of small limestone rubble about 2 foet thick. Soat tered over the surface of the momal, just beneath the earth capping, were found a number of fragments of day figmeines. The best preserved of these were three human faces, an arm with the hand holding a small hird, a hird's head, an alligator's head, and a plaited cotton breastplate. At depths varying from 2 to:3 fent, six interments were found: of these

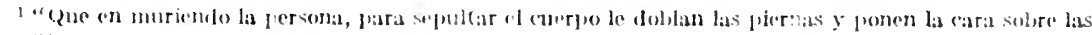
renlillias

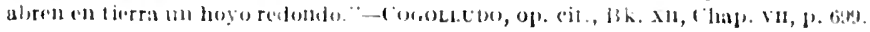


only a few fragments of the skull and long bones remained, not enough to determine even the position in which the corpse had been placed at burial. With the bones, in some cases close to them, in others at some little distance, the following objects were discovered: One rubbing stone (for grinding corn), 2 pear-shaped flints, 9 flint hammerstones, 1 ax head, 1 flint scraper, 1 broken hone of slate, 1 flint spearhead, 2 fossil shells, 2 pieces of brick-like pottery, 1 pottery disk, 3 small boads, and 1 shell.

On reaching the ground lovel of hard compact earth, it was found that an oblong trench had been eut through the latter clown to the limestone rock beneath, 3 feet in breadth, and varying from 2 to 4 foet in depth; this trench had been filled in with small rubble. In its inner wall, at the north side of the quadrangle, three interments had been made by scooping out small cists in the oarth, depositing the remains therein, and filling in with limestone dust and rubble. With one of these burials was found a small three-legged pot, of rough, unpolished pottery: with another, a ressel in the form of a quadruped, 7 inches in length, the identity of which is difficult to determine; and with the third a small saucer-shaped ressel of red ware, and a nearly spherical ressel of dark polished red ware. Within the latter were discovered a few small animal bones, some fresh-water smail shells (as are found at the present day in the neighboring swamps and eaten by the Indians), and a few hivalve shells. It seems probable that this ressel contained food, either as an offering to the gods or for the use of the deceased in his passage to the noxt world. It is not uncommon to find considerable accumulations of the shells of conchs, cockles, snails, and other edible shellfish, with the bones and teeth of deer, tiger, gibnut, snake, and (along the seashore) manatec, in British Honduras mounds; but the remains of food offerings contamed within a ressel are of rare occurrence. ${ }^{1}$

A number of these large flat mounds containing multiple burials in: we been from time to time completely dug down near Corozal, in order to obtain stono for repairing the streets. Beneath nearly all of them were found trenches eut through the earth down to the subjacent limestone. These trenches varied from 2 to 5 feet in breadth; in the case of the smaller mounds they formed a parallelogram, a triangle, or even a sing!e straight line: in the larger mounds two parallelograms were joined by parallel trenches (see fig. 23). They were invariably filled with small rubble, and a few of them contained

1 Among the modern Maya Indians of this area food is no longer flaced with the dead, but every IIanal pithn, or All souls' Iay, tortilla posol, meat, and other fools are flaced upon the graves, on the odor of which the soul of the departed is sup posed to rerale itself. Tozzer mentions the custom of burying feod With the deat as still l ruided by the modern Lacandones. (See Tozzer, A comparative Study of the

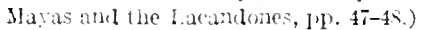

Ste also Cogolicton, op. eit., I3k. xir, Chap. vir, [). 699: "Al rededor le ponen mucha vianda, una xicara, un calabaro con atole, salvados de niniz, y unas tortillas grandes de lo mismo, que han llevado jumtamente con el euerpo, $y$ assi lo cubren despues con tierra." 
interments in their walls. The purpose of these trenches is difficult to surmise, as they could hardly have served as foundations; drainage was unnecessary; and, while the trenches themselves were never employed for sepulchral purposes, it is only occasionally that a few burials are found within cists. excavated in the earth along their margins.

Three kinds of burial seem to have been commonly employed among the ancient inhabitants of this part of the Maya area. The poorest clisse were buried in large flat mounds, some of them a half an acre in extent and containing as many as 40 to 50 interments. 'The body was usually buried with the foet drawn under the pelvis, the knees flexed on the abdomen, the arms crossed over the chest, and the face pressed down on the knees; the position, in fact, in which it would occupy the smallest possible space. With the remains aro usually found a few objects of the ronghest workmanship, as flint hammerstones, scrapers, and speatheads, pottery or sholl beads, stone motates and henequen scrupers, small obsidian knives and cores, and unglized, rough pottery ressels. In the second class of burials, arch individual has a mound, varying from 2 to 30 feet in height, to himself. Soveral mounds of this class have already been described from the neighborhood of Corozal. The objects found with interments of this class aro nsually more numerous and of better workmanship than those found in the multiple burial mounds, though they do not show much greater variety. The position of the skedeton, where it has heen possible to ascertain this, is usually tho sime as in the multiple burial mounds: oecasionally, howover, it is found in the prone position, and, in rare instances, buried head down. The third mode of burial was probably reserved for priests, raciques, and other important individuals. The interment took place in a stone cist or chamber, within al larere mound, varying from 20 to 50 foet in heighte. The skeleton is fouml in the prone position, surrounded by well painted and deropater vases, together with beatiful greonstono, sholl, obsidian, and mother-of-pearl beacls, gorgets, studs, ratr plugs, and other orminments.' Some of these momnds contain two oreven three dhimmbers or eists, superimposed one upon the other. 'The skeletom is

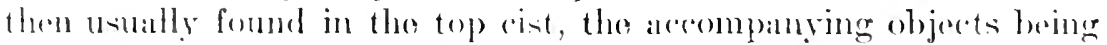
placed in the lowere ones. In one instance partial cremat ion seremed to hase beren practiced, as fragments of half-burmed human boules wore found in al latre pottery urn.

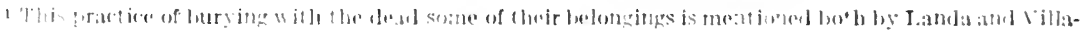

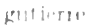

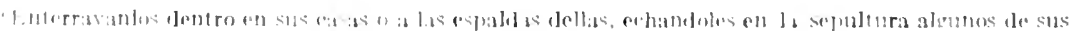

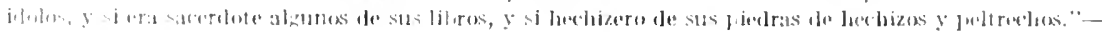

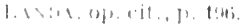

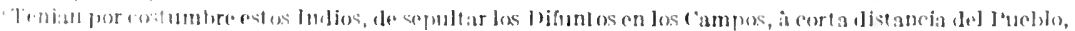

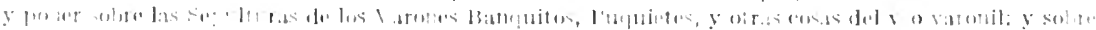

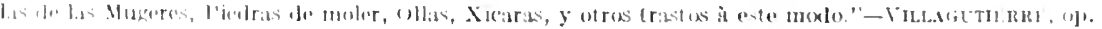
1.ji... 19.313.
} 


\section{Mound No. 31}

Mound No. 31 was situated close to the Rio Nuevo, about 16 miles from its mouth, in the northern part of British Honduras. It was a somewhat flattened mound, 15 feet in height, built of blocks of limestone, limestone dust, and earth. At a depth of 9 feet, the angle of a ruined building, formed by two walls averaging 2 feet high, intersecting at right angles, and built of squared blocks of limestone, was

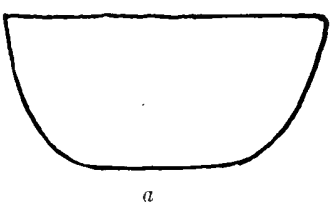

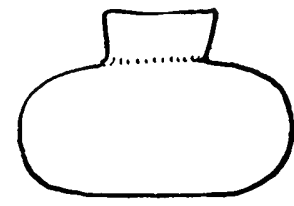

b

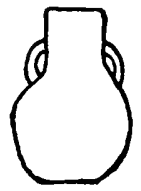

$c$

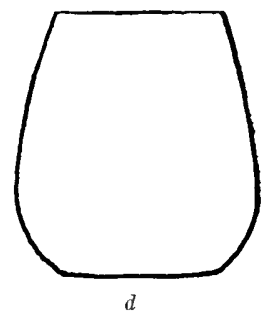

FIG. 73.-Pottery vessels found in Mound No. 31.

brought to light. The walls enclosed part of a floor of smooth, hard cement. Numbers of blocks of squared stone were found throughout the upper part of the mound, which had evidently at one time formed part of the ruined building. Resting on the cement floor, close to the wall, were found nine pottery ressels, corered with limestone dust. Five of these were of the type shown in figure $73, a$, of dark-red, rather coarse pottery, 12 inches in diameter at the rim. One, pictured in figure $7 t$, is the usual Maya chocolate pot, similar to the one already described (see fig. 24, $g$ ), except that the spout, instead of bending

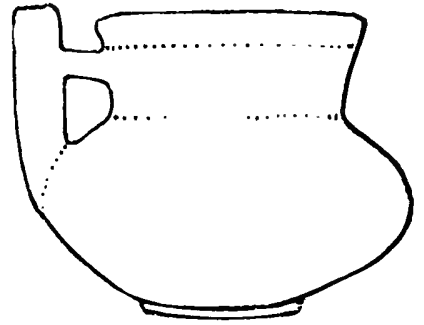

FIG. 74.-Chocolate pot found in Mound No. 31 . inward toward the ressel, passes directly upward parallel to its perpendicular axis, an arrangement which must have rendered it far easier to drink from the ressel or pour fluid out of it. The three other vessels found are illustrated in figures $73, b, c$, and $d ; b$ is of polishod chocolate-brown pottery, 3 inches in diameter by 5 inches in height; $c$ is of thick red pottery, 3 inches high, with two small handles for suspension, one on each side; $d$ is of coarse polished red ware, unusually thick and elumsy, 12 inches high by 8 inches in diameter. Each of these ressels contained a single small polished greenstone bead. No other objects were found associated with them, and there was no trace of human bones. Excavations were made in this mound to the ground level without results. The lower part of the mound was built of large blocks of limestone and rubble, held loosely together with friable mortar. 


\section{Mouxid No. 32}

Mound No. 32 was situnted quite close to No. 31. which it rery closely resembled in hoth sizo and construction. At a dipth of 9 feet the end of a small building constructed of squared blocks of limestono was bronght to light. Tho walls woro still standing to a height of 2 to 3 feot, and showed traces of a red stucco covering on their inner surfaces. The cement floor of the building and the platform upon which it stood could also be traced. Lying upon this: floor were five pottery vessels and an unfinished flint celt. Two of these vossels were precisely similar to that shown in figure 73, $a$ : one is a large, circular, shallow plague, of rather thick reddish-brown pottery, in the conter of which a small hole has been made, evidently with the object of rendering the plaque useless. The last two vessel. aro illustrated in figure $75, a, b . \quad A$ is an unusually large vessel of very coarse, thick, red pottery, 18 inches high, which had probably been
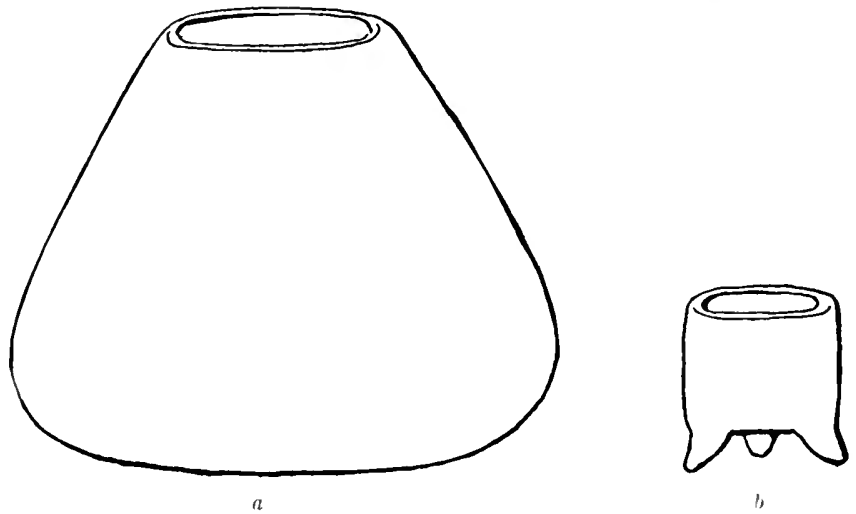

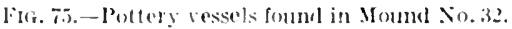

used to contain corn or some such dry material, as the potcery was too friable and soft for a cooking pot, or oven to hold water. $b$ is a small three-lecered vase, 4 inches high, of coarse, unpainted pottery. Each of these fire vessels, with the exception of the pluque, contained a single polished greenstone bead. The celt was roughly blocked out of rellowish flint. No objectsexcept those abovo described were found with theso vensels, nor were there any traces of human burial. Exarvations were mate in the moned to the ground level, and it was found to be composed betow the platform upon which the building stood of a solid mass of rubble and linestono held together by loose, friable mortate. There are numerous groups of mounds of all sizes in the meighborhood, and judging by these, and by tho potsherds and flint and obsidian chipe which one finds st rown over tho surface of the soil in aroat profusion, it must haro beon a densely populated recrion inter - 1s-Bull. (it) -9 
at ono timo. Tho two life-size human heads shown in figures 76 and 77 wero found close to these two mounds in digging a posthole. Figure 76 represents a grotesquo head cut from a solid block of crystal-

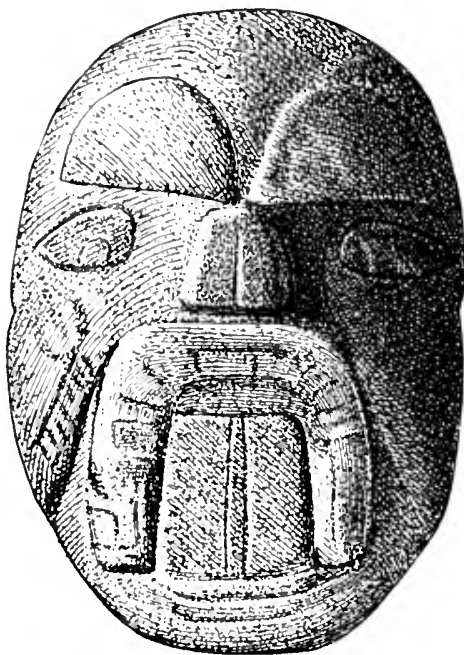

Fig. 76.-IIead cut from limestone found in Iound No. 32.

line limestone. Figure 77 is a mask, rather crudely cut from greenstone and unpolished. Both were buried in tho marl and wore unaccompanied by other objects.

\section{Mound No. 33}

Mound No. 33 was situated near Bacalar, in the Province of Quintana Roo, Mexico. It was 6 feet in height by 20 feet in diameter, and was built of blocks of limestone, limestone dust, and earth. Near the summit of this mound, close to the surface, was found the small soapstone lamp illustrated in figure $78,4 \frac{3}{4}$ inches in length. by $1 \frac{3}{4}$ inches in depth. The lamp is decorated in front with a floral design, and at the back by wing or feather-like ornaments, possibly meant to represent the tail and half-folded wings of a bird. It is finely polished throughout but had probably never been used, as in hollowing out the interior the maker had carried one of lis strokes too close to the surface, making a small hole, which would have allowed the oil to escape. There is a freedomand lack of conventionality, both in the pleasing and naturial florial design and in the flowing lines of the back part of this little lamp, which are totally unlike the cramped and highly conventional style to be observol in similarsmall objects of ancicnt Maya manufacture. So widely does it differ from Maya standards that there (an be but little doubt that it was introduced in post-Columbian days, probalbly very soon

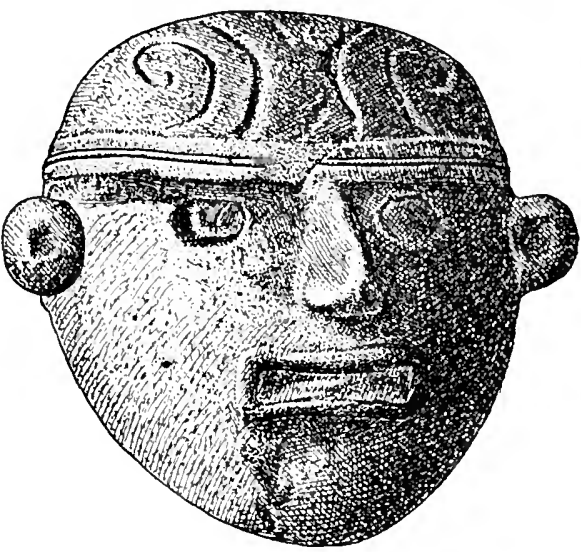

Fig. 77.-Greenstone mask found in Mound No. 32. after the conquest, especially as in the same mound was found one of the small painted (lay figurines so common in mounds in this neighborhood. which with the censers probably belonged to the 



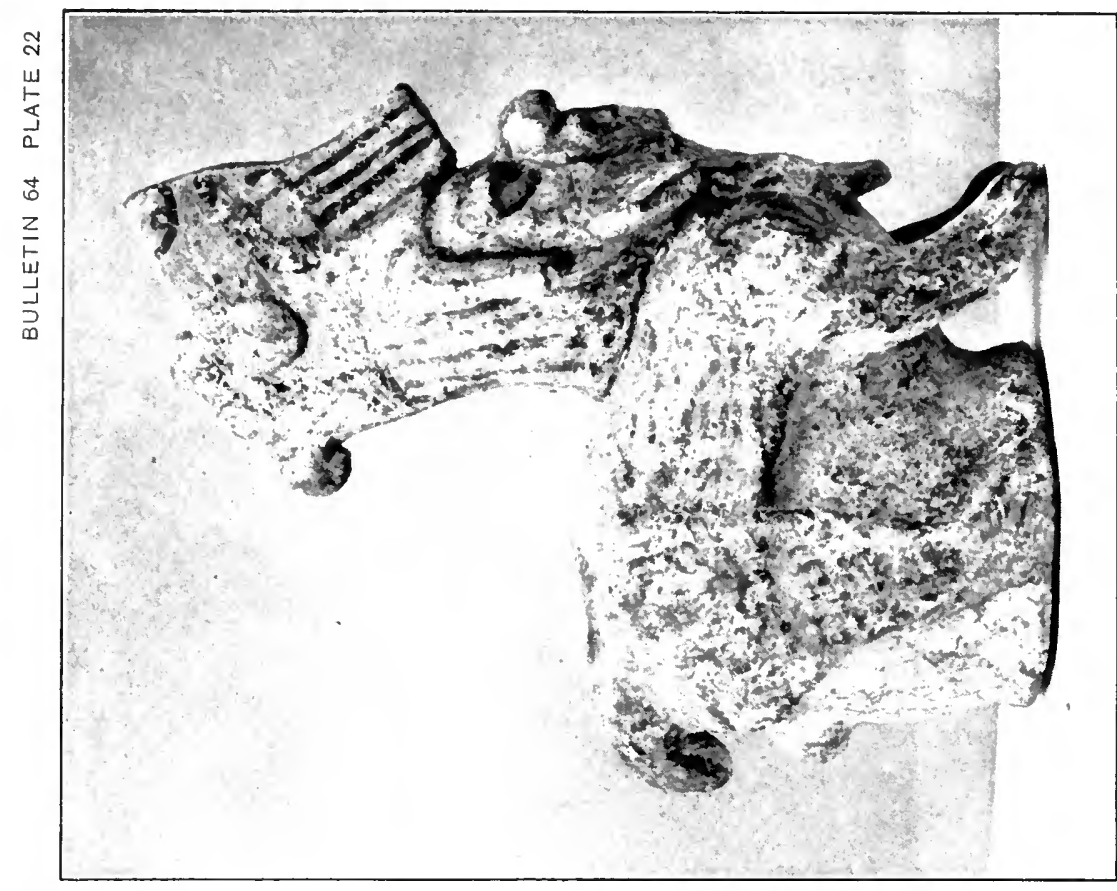

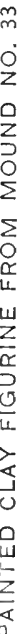

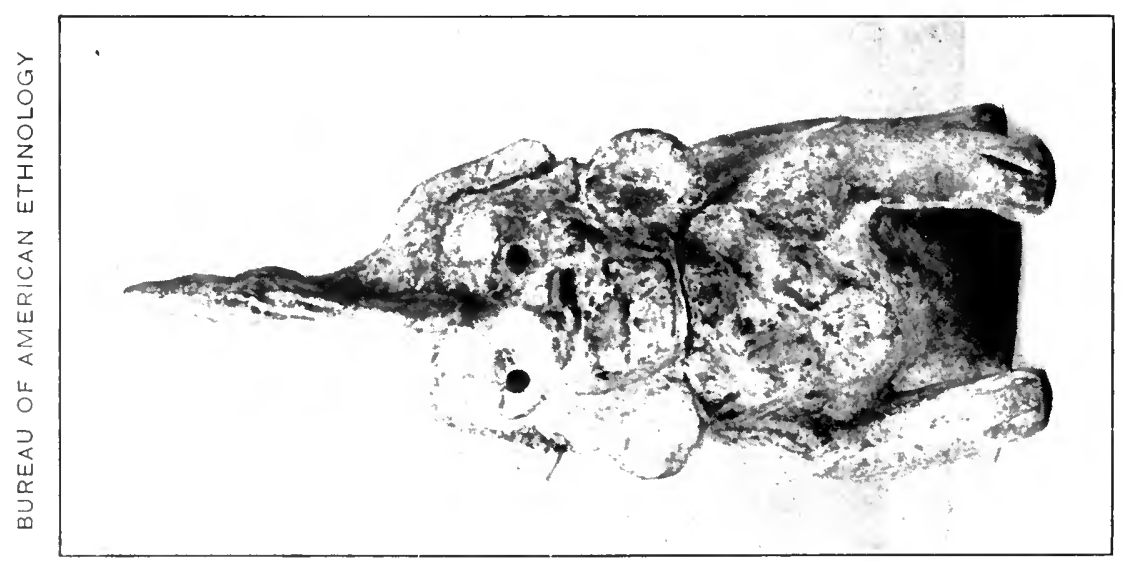


latest period of Maya culture. Another explanation which suggests itself is that the lamp was buried in the mound at a much later date (possibly during the troublous times of the Indian rebellions, between 1840 and 1850) by someone who wished to hide it temporarily, and that it had no connection with the original purpose of the mound. No other objects were found in this mound, with the exception of a number of potsherds, till the ground level was reached, where, near the center of the mound, the painted clay figurine shown in plate 22 was uncovered. This represents a cleer with a human head, whose healdress is the upper jaw of some mythological animal. The back of the figure, which is hollow, con tains a small opening near the tail, covered with a conical plug of clay. Within were

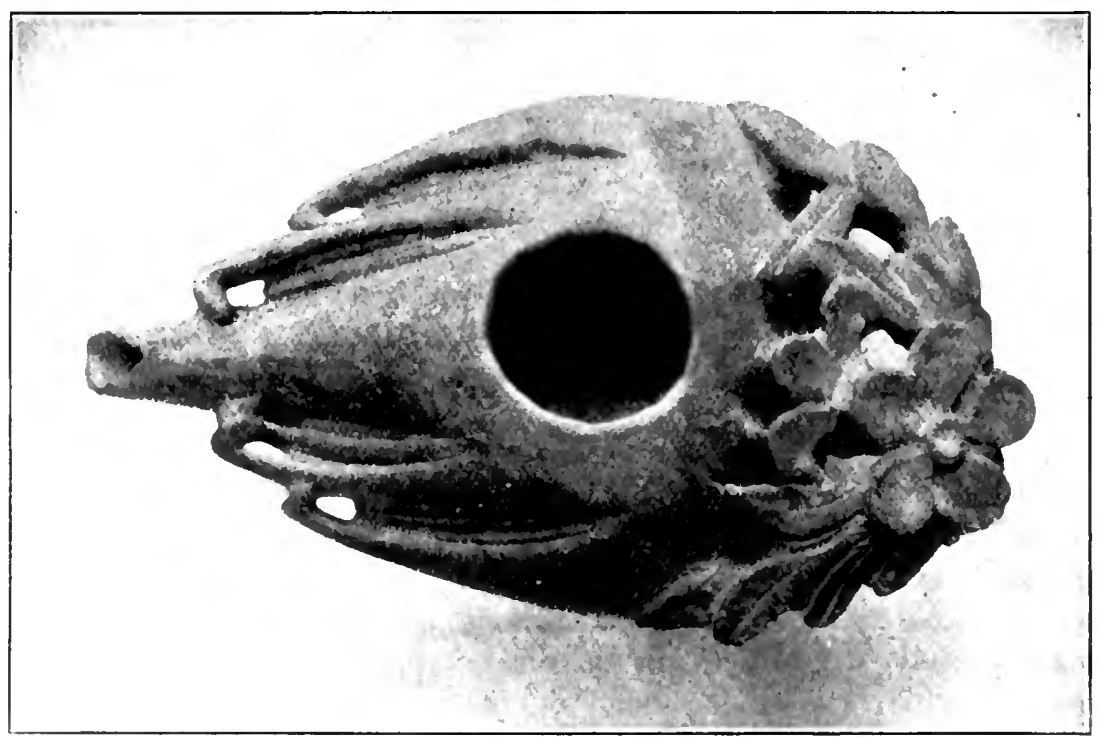

F1G. 78.-Soapstone lamp found in Mound No. 33.

two small beads, one of polished red shell, the other of polished greenstone. The whole figurine had been coated with lime wash, orer which were painted black lines, dots, and circles.' 'The human fince, carringe, gorget, and part of the headdress are painted blue, while the mouth of both the human face and the face in the headdress are painted red. Near the figurine lay a vesed (fig. 79) of rough yellow pottery, unpainted and undecornted, with two small citr-like projections just below the rim. No bones and no trace of human burial wore found in the monnd.

This white line wash, appling evenly to the entire surface, over which other colors were afterward

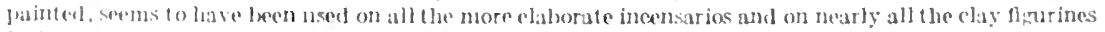
It is stifl rmployed by the motern bacandones in the manufacture of thejr broseros. (Fee Tozztr, A

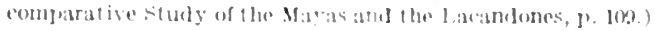




\section{Mouxin No. 34}

Mound No. 34, situated near Protreso, in the northern district of British Honduras, was 5 feet in height, roughly circular, and about 20 feet in diameter at the base. The mound was built throughout of rough blocks of limestone, rubble, and earth. At the ground level, about the center of the mound, were found large flat unworked flags, which seemed to have formed the roof of a small cist that had caved

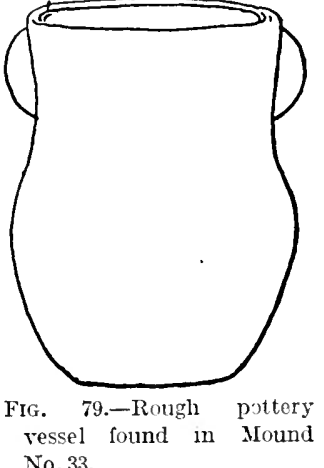
No. 33.

in. Beneath these were found a few fragments of bone, which crumbled away as they were being removed, with a small spherical vase of rough unpainted pottery, $1 \frac{1}{2}$ inches in diameter (pl. $21, a)$. This was decoratod on the outside with a human head wearing a peaked headdress, somewhat resombling the cap of liberty, and large circular ear plugs in the ears. Below the head projected a pair of arms with the hands clasped in front, supporting between them a small pottery ball. Within this little rase, which was filled with earth and limestone dust, were found: (a) A small earthenware bead (fig. S0, $a$ ). small, very delicate obsidian knife, the tip of which is broken off, but which otherwise shows hardly any signs of use (fig. 80, b). (c) - The terminal phalanx of a small and delicate finger, in a very fair state of preservation (fig. $80, c$ ). The burial of a terminal phalanx of one of the fingers of the mother, with a favorite child, is not an unknown custom among semicivilized peoples, and it is possible that this little mound contains such an interment. The bones of the child being fragile and deficiont in caleareous matter, may well have almost disappeared, while the finger bone of the mother, being of more compact bony tissue, and protected to some extent by the vase in which it lay, has been preserved. The crudeness of the modeling of the little rase and of the face and arms thereon would suggest that it may have been a plaything of the child during life, and

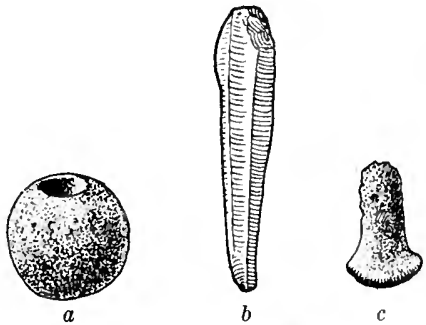

FIG. 80.-Objects found in Mound No.31. eren perhaps may have been modeled by its own hands. 'The obsidian knife may have been used by the mother to separate the bone at the last finger joint. The little figure which decorates the outside of this vaso closely resembles those curious figures in a diring position, witharms pointed downwird and feet upward, which are not uncommon in this area. Figure 81 shows one represented on the outside of a small vase; several are to be found, molded in stucco, on the 
ruined buildings of Tuluum, on the eastern coast of Yucatan, just below the island of Cozumel, and they are occasionally, though rarely, found decorating pottery incense burners, instend of the commoner representations of the Gods ltzamna and Cueulcan. Neither Landa, Villagutierre, nor Cogolludo mention the custom as practiced by Maya mothers or relatives on the deaths of their children. Had it been prevalent at the time of the conquest it seems hardly possible that such a practice could have eseaped their notice; on the other hand, if the solitary phalanx had not boen buried with the dead as a memorial, its presence under these circumstances is very diflicult to explain.

In nearly all extensive groups of mounds one or more middens, or refuse mounds, are to be found. 'The four mounds next deseribed, though varying much from one another, are all distinctly of this type.

\section{Mound No. 35}

Mound No. 35 was situated near the Cayo, on the Mopan River; it forms one of a group of about 30 mounds scattered over a considerable area. It was 12 feet in height and seemingly had been about 30 feet in diameter, but situated as it was, immediately on the river bank, nearly half of it had been washed away by the floods of successive rainy seasons, leaving a clean section almost through the

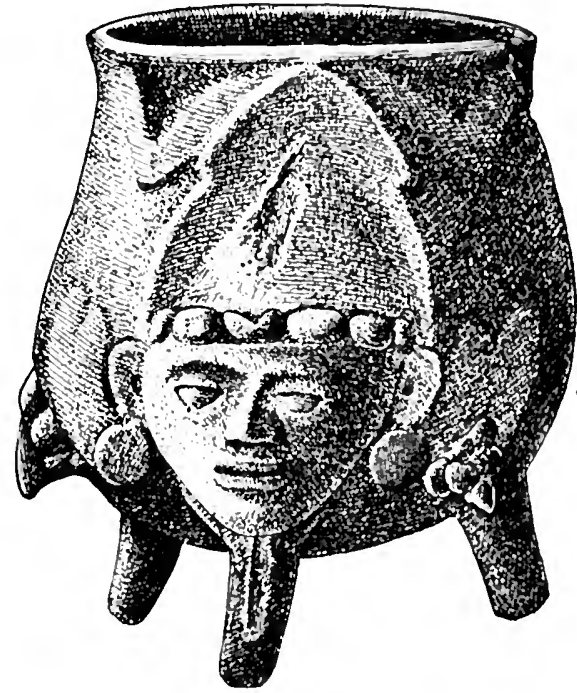

Fif. 81.-Figure in diving position on small vase. center of the mound, very favorable for obsorving its construction. The lowest layer, 1 to 2 inches in thickness, resting on the ground level, was composed of ashes mixed with fragments of charcoal; above this wits a layer of earth and stones about 1 foot in thickness, and above this a further layer of ashes; and so on to the top of the mound - strata of ashes averaging 2 inches thick alternating with strata of earth areraging about 1 foot. No objects with the axception of a few potsherds were found in the earth layers, but the layers of ashes were rich in flint and obsidian clips, fragments of eonch and smail shells, chy beads and malacates, potsherds in great rariety and abundance, with the bones of the deere, gibunt, and peceary. It would secon that this momed had formenl a sort of kitchen mideden; that when a cortain amoment 
of refuse had been deposited it was covered with a layer of earth, and that the mound must have been in use for a considerable time to have reached its present height.

Small mounds containing considerable quantities of ashes and charcoal mixed with earth and stones, together with refuse material, as flint and obsidian chips, broken implements, potsherds, bones, shells, clay beads and malacates, and similar indestructible objects, are not of infrequent occurrence, and probably mark the sites of ancient kitchen middens. Two such mounds were found on the mainland, south of the island of Tamalcab, in Chetumal Bay, Yucatan, situated in what seemingly had been a village site, occupying an area of approximately 20 acres. Great numbers of potsherds, fragments of pottery, images, beads, malacates, chips and broken implements of stone and obsidian, broken metates, fragments of conch and cockle shells, stone watertroughs, and other indestructible rubbish were found scattered in great profusion over the whole of this site.

\section{Mound No. 36}

Mound No. 36 was situated at Sarteneja, in the northern district of British Honduras, quite close to the seashore. This mound was 2 feet 6 inches in height, about 12 feet in diameter; it was composed throughout of conch shells mingled with cockle and whelklike shells. Nothing except the shells was found in this mound, which forms one of a group of similar mounds, evidently dumping places used by each house, for the disposal of the shells of shollfish brought in from the reef by the fishermen after the fish had been extracted and eaten.

\section{Mound No. 37}

Mound No. 37, situated close to the next preceding mound on the soashore, at Sarteneja, is about 2 feet high by 12 to 15 feet in diameter. It is composed almost entirely of fragments of rather rough unpainted pottery and seemingly marks the site of a manufactory of this class of ware, as great quantities of fragments are also to be found scattered in all directions around the mound. A small quantity of earth was mingled with the potsherds, but nothing else was found in the mound.

Mouxd No. 38

Mound No. 38, situated about 5 miles from Corozal, in the northern district of British Honduras, was 6 feet in height by 15 feet in diameter, with a flattened top. It was covered with a layer of humus and contained nothing but fragments of weathered stone, of sizes varying 
from small rubble to blocks woighing 30 to 40 pounds. Similar mounds are found elsewhere and are apparently merely heaps of stones, which have been picked up on the surface of the fields, as, unlike other mounds, thoy contain no clay, limestone, or marl dust, mortar, or other binding material and no trace of burials or any object of human construction.

\section{Mouxd No. 39}

Mound No. 39 was situated on Wild Cano Cay, a small island off the southern coast of British Honduras. 'The island seems to have been built up witl stono and other material brought from the mainland and to have been used as a burial place. Soveral small mounds are scatterod over the face of the island; unfortunately most of them had been dug down for the sake of the stono they contained and tho objects from tho graves lcst or griven away. Those which could be traced consisted chiefly of copper ornaments, as rings, gorgots, and studs. Mound No. 39, the only one whose contents were ascertrined with any degreo of accuracy, was a small circular mound 10 foot high, built of sand and blocks of reef stone; near the ground lorel, about the center of tho mound, a singlo human intorment
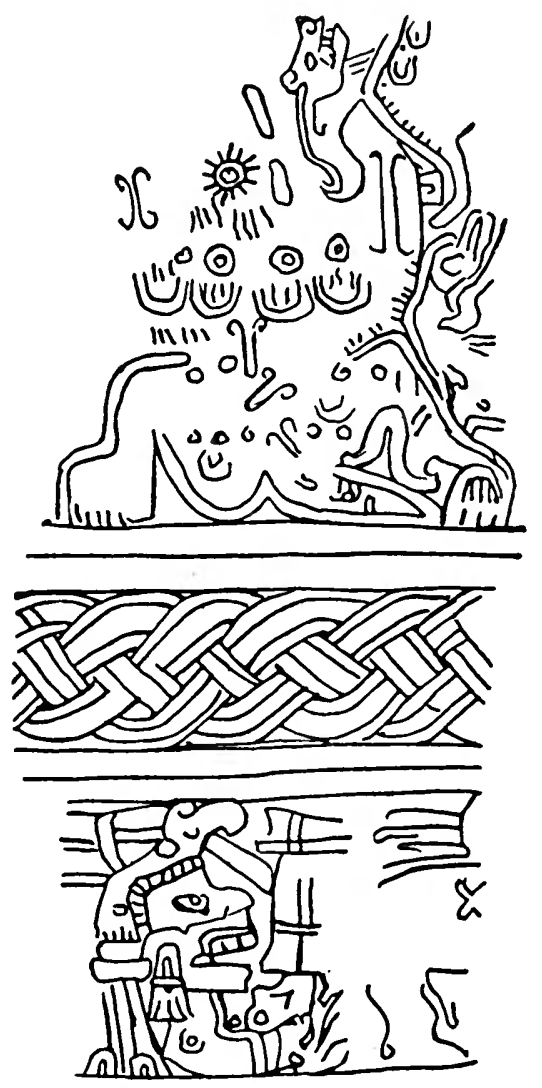

FIG. 82.-Design incised on femur of deer found in Mound No. 3\%.

was found, the bones of which wore in an andranced stato of decay; mingled with theso were: (a) A round red earthenware pot, containing a fow small circular bends mate from conch sholl and five or six medium-sized, unused obsidian knives. (b) A second somewhat larger pot, of the samo shapo and material, which contained tho upper part of the femur of a deor, on which is incised the design shown in fignre 82 . This is noatly exocuted in shallow lines; the upper part avidently represents a tiger, or the skin of that animal, and is separated hy a platted design form the lower, which may he intended as a ropresentation of the Ciod Itzanna. With 
tho bone were two objects of copper, one a finger ring constructed of thin flat bands two-fifths inch apart, joined by double scrolls; this is very much worn, either from use or from oxidization, consequent on long exposure in the damp soil. The second copper object (fig. 83) was probably used as a gorget, or for attachment to a headdress, as at the back is seen a cruciform grille, evidently intended to hold it in place. This object is in the form of a human face, the lower part with its large mouth, thick prominent lips, and flattened nose, exhibiting marked negroid characteristics, which the upper part with its bulging prominent forehead contradicts. The headdress is ornamented with three spikes passing along the sagittal suture from front to back, while under the chin is a projection probably intended to represent a short beard. The ring and ormament are both strongly suggestive of Spanish influence, as the face with its thick lips, flattened nose, and bulging

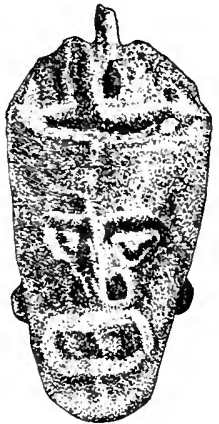

lig. 83.-Copper nbject found in Mound No. 39 . forehead is totally unlike any type with which the Maya were likely to come in contact, unless, indeed, it were the Carib, who even at this early date had possibly formed small settlements as far north as the southern coast of British Honduras. If the objects were of Spanish origin they were probably obtained from some Spanish settlement farther north, possibly Bakhalal, as there was no settlement between that town and the coast of Guatemala till many years after the conquest. That the cult of Itzamna was still flourishing is shown by the effigy of the god incised on the deer bone, and according to Villagutierre, the Indians of this neighborhood up to the end of the seventeenth century were closely allied to the Itzaex, ${ }^{1}$ who still freely practiced their ancient religious rites.

\section{Mocio No. 40}

Mound No. 40, situated near Pueblo Nuevo, on the Rio Hondo, consisted of a ridge about 10 feet ligh by 40 feet in length. On the summit of the ridge near its center, covered only by a layer of humus, was found a small rough three-legged vase 3 inches high, containing a single long, polished, greenstone bead. The upper part of the ridge was found to consist of blocks of limestone, limestone dust, and rubble, on removing which to a depth of about 4 feet the ruins of a building were brought to light (fig. 84). The bones were in so poor a state of preservation that it was difficult to determine the exact

1 speaking of the boundaries of the territory of the Itzaex, Villagutierre (op. cit., p. 489), gives the sea as its eastern limit. All the tribes between the lagoon of ltza and the sea were evidently not subjeet to the Itzaex, however, as he mentions (Lib. Ix, eap. In, p. 554) a number of trlhes inhabiting this area with whom they were at war, and states (Lib. vi, Cap. $N$ p. 352) that the Mopanes and Tipu Indians were not subject to the Caneh of liza. 
position in which the body had been placed at the time of burial; it had, however, certainly been fully extended. Close to the heal were found fragments of three round bowls, all precisely similar in both size and coloring. Each was of the shape shown in figure $71, b, 3 \frac{1}{2}$ inches high by $6 \frac{1}{2}$ inches in diameter, and was made of rather fine ashcolored pottery, finely polished. Each of these bowls before burial had had the bottom knocked out. 'The mound beneath the building was composed of blocks of limestone, rubble, and limestone dust, forming a tough, solid, compact mass. This would seem to have been a small private house, not a temple, which (probably on account of the death of its owner) had been deliberately wrecked, and the owner's body buried beneath the cement floor of the one chamber remaining partially intact. Fresh cement seems to have been applied over the

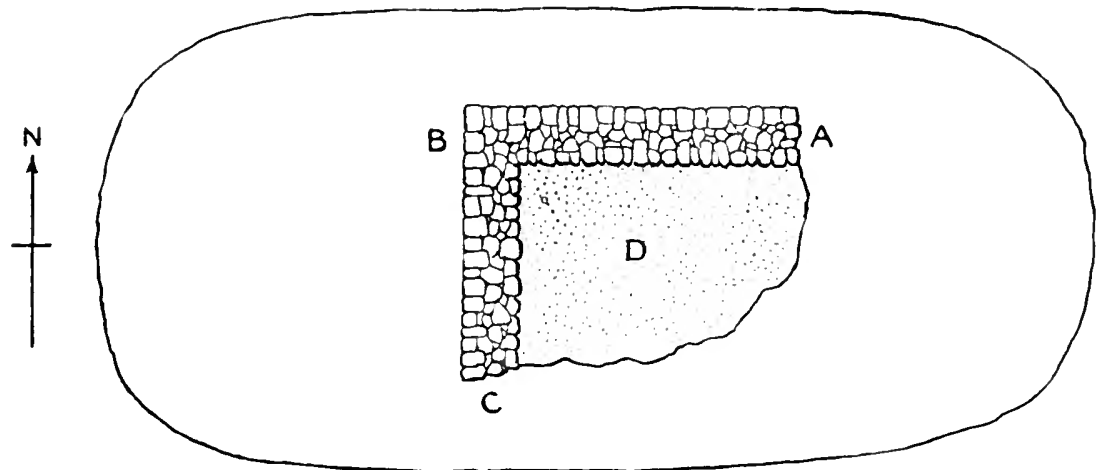

Fif. 8.1.-Ruins found in $\mathbf{M o u n d}$ No. 40. These consisted of broken-down wails about 2 feet high, joinng each other at right angles. Of the wall $A-B, 10$ feet remained standing; of the wall $B-C$, 8 seet. The shuled space inchded between the walls was covered with hard smooth cement, which had been broken away to a rough edge at its onter border and was continuous at its inner border with the stucco which was still partly adherent to the walls. The wall's themselves were built of blocks of limestone (scuared on their outer surfaes but rough within), rubble, and mortar; they were nearly 2 feet thick. The long diancter of the ringe pinted almost due east and west. An excaralion was made in the cement lloor, and at the depth of 18 inches, at the point narked $D$, a single interment was brought to light.

grarm before the greater part of the house was pulled down and the wreckuge piled up, to form a capping to the mound upon which the house stood.

\section{Mound No. 41}

Mound No. 41 was situated in the northern district of British IIonduras, about 9 miles from Corozal. It consisted of a circular wall or rampart varying from 4 to 10 foret in hoight, inclosing a space 30 yards in diameter. The wall was built of earth and biocks of limestone, and in places had become considerably flattened out from the action of the heary tropical rains of this region. "To the north an opening "1. gap existed about 10 gards across. Exeavations were made in the cheireline wall of the inclesure, and alos in the central spance, but nothing except fragments of pottery was discensered. 
Mounds of this kind are found throughout the area, though not in great numbers. Some of these are circular or horseshoe shaped, some crescentic, and others curved or even straight ridges. As a rule they contain nothing except a few potsherds, which would naturally be picked up with the earth of which most of them are made; in some, however (especially in the straight ridges), superficial interments have been found. These mounds were probably used as fortifications, the circular, horseshoe-shaped, and crescentic mounds being particularly well adapted to this purpose.

At Yalloch, just across the Guatemala boundary line from Choro, a small village in the western district of British Honduras, the Alcalde made a remarkable discovery a few years ago. While hunting for a gibnut he traced one to a hole in the ground; on poking a stick into this hole, he was astonished on withdrawing it to find that he had brought out on its end a small painted pottery cylinder. The hole on being cnlarged proved to be the entrance to a chultun, one of those curious underground chambers cut in the limestone rock found throughout Yucatan and the northern part of British Honduras, especially in the neighborhood of ruins. This chultun contained numbers of fragments of very finely painted and decorated pottery vases, together with two complete cylindrical vases, an ovoid vase, and a pottery cylinder without bottom. Some of these were within the chultun, some in a pit sunk in its floor, from which at a later date several pieces of beautifully decorated pottery were taken. The pit had evidently been used as a burial place, in which the memorial pottery was deposited with the body. Merwin found similar painted Maya vases some years later in a chamber covered by a mound, at Holmul, within a few miles of Yalloch, and at Platon, on the Mopan River, a sepulchral chultun was cleared out in which human bones still remained. (Pls. 23-28.)

Near the point where Blue Creek or Rio Azul joins the Rio Ilondo, in the northern district of British Honduras, is situated in the bush about 100 yards from the latter river a small circular lagoon, of a deep blue color and considerable depth; from this flows a narrow stream, also deep blue in color and highly impregnated with copper, which opens into the main river just below the mouth of the Rio Azul. The little lake is bounded on its eastern side by an almost perpendicular cliff of limestone, in which are several small caves and one large cave. The interior of one of the smallest of these caverns, situated near the base of the cliff, not more than a few yards in depth, was roughly hewn out so as to form shelves. Upon these were found several hundred small binequins of incense, varying in size from 3 to 4 inches in length by $1 \frac{1}{2}$ to 2 inches in breadth, to 8 to 10 inches in length by 3 to 4 inches in breadth. The incense was composed of the gum of the white acacia mixed 
with various aromatic substances; when burned it gave off a very pleasant odor. The gum lad evidently been poured while in a liquid state into small bags, made of palm leaves, as in some of the binequins considerable fragments of the palm leaves were still adherent to the copal, and in all, casts of the leaves were left on the soft surface of the gum before it solidified. The binequins which the present-day Maya Indians manufacture as receptacles for their homemade lime, though vastly larger, are preciscly similar in shape, construction, and appearance to those their ancestors used as receptacles for copal. The entrance to the large care was near the summit of the eliff and so difficult to reach that it enn never have been long used as a place of residence, though it would form an exceedingly strong position to hold against an attack from without, as it is necessary to cross a fallen tree trunk in order to enter, and this might easily be hauled back into the cave or pushed away from its mouth, leaving it practically inaccessible. Nothing was found in the cave except a large quantity of bats' excrement and of rough red potsherds. 


\section{TWO PAINTED STUCCO FACES FROM UXMAL}

Two human faces molded in stucco and painted were discovered in a small stone-lined chamber situated beneath one of the end rooms of the Casa del Gobernador in the ruins of Uxmal, northern Yucatan. The room was accidentally disclosed by the caving in of a small part of its roof. One of its walls was covered, above a stone cornice, by a frieze of hieroglyphs, and against this wall stood a small square stone altar, each side of which had been decorated with a human figure molded in stucco and painted. Unfortunately these figures had fallen; the two heads here described are the best preserved parts of them which remain. Describing the sculpture in stone which adorns the outside of the Casa del Gobernador, Stevens ventures the opinion that some of the heads were portraits of celebrated men of the period.

The discovery of this chamber is extremely interesting, as it opens up the possibility that many, if not all, of these rast substructures, built apparently of solid stone, which throughout Yucatan support more or less ruined buildings, may in fact be honeycombed with chambers. Sterens first suggests the possibility of this. Unfortunately since Stevens's day little or nothing has been done throughout Yucatan in the way of excaration to verify the truth of his surmise.

Of the two heads now described, one probably represents a male, the other a female; there is, moreover, a marked individuality about each of them which renders it extremely probable that they are portraits, possibly of some "Halach Uinic" (real man, or chief) of Uxmal and his wife, during the palmy days of the triple alliance.

Each face is painted black with white circles round the orbital margin, red rims to the eyes, and brick-red oval patches at either angle of the mouth. The center of each upper lip is decorated by a figure 8 shaped labret, the lower portion of which has been broken away in the male head. Over the bridge of each nose is a curious ornament consisting of a small oblong object with rounded corners, held in place by a loop passing down the median line of the bridge. Over the center of the forehead in both faces hangs a pendant, that of the male composed of four small round beads, that of the female appearing as a rounded comblike excrescence. Traces of the headdresses remain as a few feathers above each forehead. Both heads were probably held within widely distended animal jaws, as a part of the lower jaw is seen below the chin in the male head, where also 
the large circular red ear plug still remains on the right side. The measurements of the faces are as follows:

Male.-Top of headdress to bottom of lower jaw of animal head holding the face, $11 \frac{3}{10}$ inches; top of headdress to bottom of chin, $9 \frac{3}{10}$ inches; forehead below headdress, to bottom of chin, $8 \frac{3}{10}$ inches; extreme breadth of face (midway between a transverse line passing through the pupils and one passing immediately beneath the lower margin of the nasal septum), $7 \frac{1}{10}$ inches; extreme breadth at level of the pupils, 7 inches; length of nose, $2{ }^{6} \delta$ inches; breadth of nose, $1_{1} \cdot$ inches.

Female.-Top of headdress to bottom of chin, $10_{\frac{4}{4}}^{4}$ inches; forehead below headdress to bottom of chin, $8{ }_{10}^{8}$ inches; greatest breadth of face, at same level as the male, $7_{10}{ }^{8}$ inches; greatest breadth at the level of eyes, $7 \frac{6}{10}$ inches; length of nose, $2 \frac{8}{10}$ inches; breadth of nose, $1 \frac{9}{10}$ inches.

The city of Uxmal belongs to the later, or northern Maya, civilization. Unlike the earlier southern cities, Lxmal is without a single initial series date by which its age might be approximately determined. It was founded by Achuitok Tutulxu, probably about the year 1000 of the Christian era. In the "Series of Katuns from the Book of Chilam Balam of Mani" the date given is Katun 2 Ahau, whereas in that from Tizimin it is recorded as having taken place 180 years later.' ${ }^{1}$ The cities of Cxmal, Chichen Itza, and Mayapan formed a triple alliance, which lasted for nearly 200 years, during probably the most prosperous period of the whole Maya rule in Yucatan. After the disruption of this alliance, eaused by a quarrel between the rulers of Chichen Itza and Mayapan, Uxmal gradually declined in prosperity, till at the time of the conquest its temples and palaces seem to have been completely abandoned. The city was visited in 1586 by the Frunciscan delegate Alon\%o Ponce, one of whose companions gives an interesting account of the ruins. Describing the house of the governor, he says:

Besiles these four buildings there is on the south of them, distant from them about an arquebus shot, another very large building bult on a "It ul "or hill made by hand. with abundance of buttresses on the comers made of massive carved stones. The" ascent of this "mul" is made with difficulty, since the staircase by which the aseent is made is now alnost destroyed. The building which is raised on this "mul " is of extraterlinary sumptuousuess and grandeur, and like the others very fine and beantiful. It has on its iront. which faces the cast. many figures and bodies of men and of shields, and of forms like the eagle which are fomm on the arms of the vexieans, as well as of certain characters and letters which the Mata Indians tesed in old timeall rarred with so great dexterity as surely to excite aldmiralion. The other factade. whith iaces the west. showed the sane carring. although more than half the carved

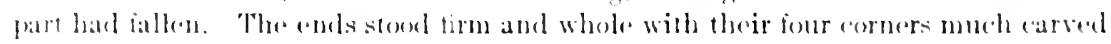

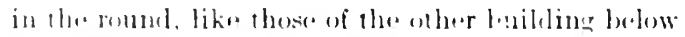

The lndians do not know 
surely who built these buildings or when they were built, though some of them did their best in trying to explain the matter, but in doing so showed foolish fancies and dreams, and nothing fitted into the facts or was satisfactory. The truth is that to-day the place is called Lxmal. and an intelligent old Indian declared to the father delegate that according to what the ancients had said it was known that it was more than nine hundred years since the buildings were built. ${ }^{1}$

From this account there appears to be little doubt that at the time of the conquest the great buildings of Lxmal were deserted and already falling into ruins. In the minds of the Indians they were eridently associated with the practice of their ancient religious rites at a much later date, for one of the reasons given by the regidor when he applied for a grant of the land upon which the ruins stand was that-

It would prevent the Indians in those places from worshipping the devil in the ancient buildings which are there, having in them idols to which they burn copal, and periorming other detestable sacrifices as they are doing every day notoriously and publicly. ${ }^{2}$

The ruins of Uxmal were probably venerated by the Indians up to a very recent period, as in one of the chants used by the modern Maya of southern Yucatan in their "Cha chac" or rain ceremony the "Noh Nah ti Uxmal," "Great house of Uxmal," is introduced, which possibly refers to the Casa del Gobernador, as this is the largest building among the ruins. 

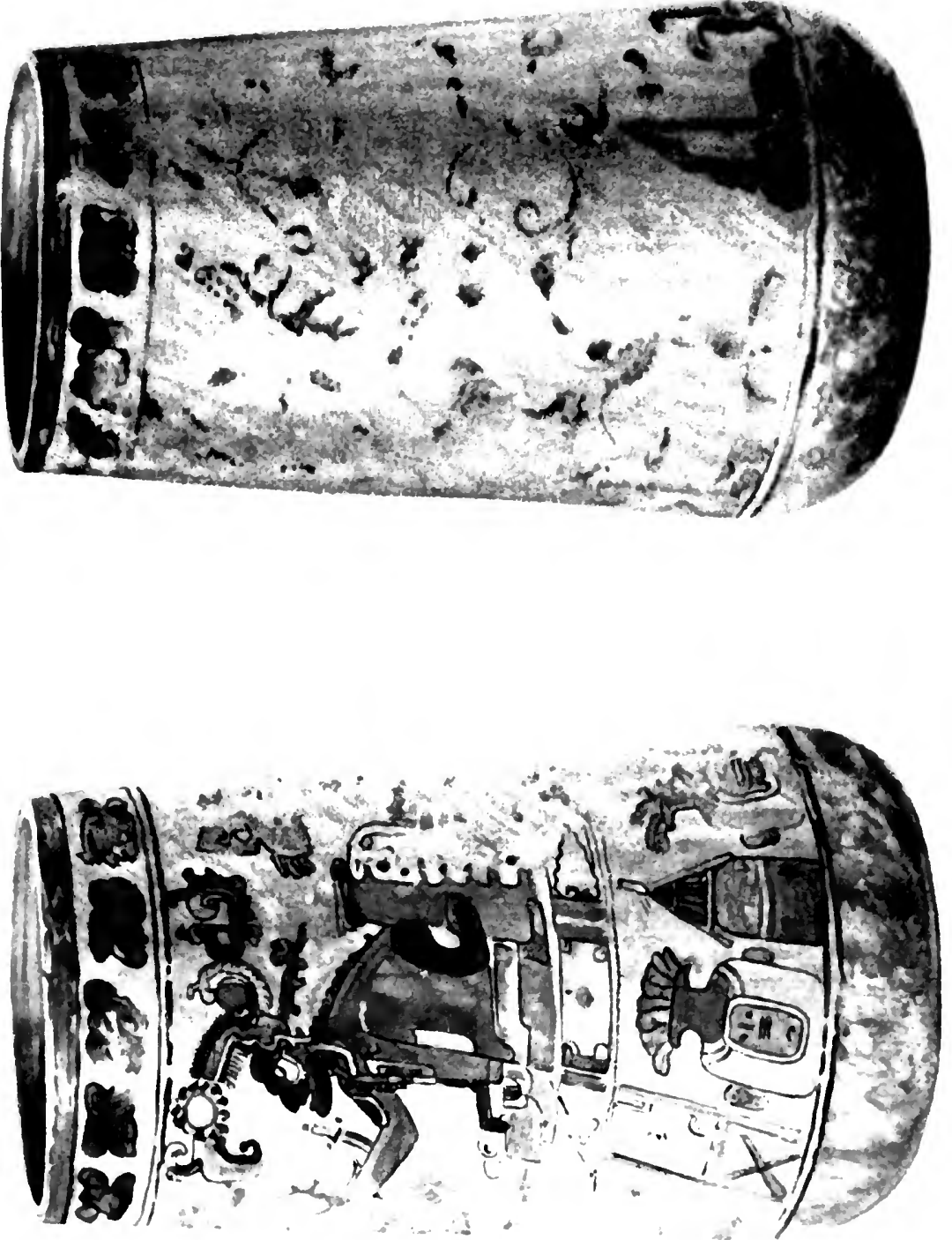



\section{EXPIANATION OF PLATE 23}

The ovoid vase shown in plate 23 is 11 inches high by $6 \frac{1}{2}$ inches in diameter at its widlest part. It is of very fine pottery, with decorations in red, black, and reddish yellow on a background of light yellow. The outer surface is divided by double black lines into three zones. The uppermost and narrowest zone contains, between a broad red band above and two narrow black bands below, a row of $10 \mathrm{glyphs}$ surrounding the edge of the vase. The middle zone, the broadest, contains upon one side (unfortunately the decoration upon the other side has been almost obliterated by time or wear) a human figure, in a crouching position, the right hand extended, the left resting upon the ground. The face is in profile, and around the left eye is seen the ornament usually associatel with the representation of a god. This may be intencled to represent Schellhas's God D of the Codices, known as the Roman-nosed Gud, probably Itzamma, as this peculiar eye ornament is often associated with him. The headldress is exceedingly elaborate, projecting far in front of and behind the head, and is decoratef with plumes of feathers. The whole figure strongly sugrests the bas-relief on the side of the door of the altar at Palenque, which is undoubtedly a representation of the god Itzamna. The curious eye ornaments, the construction of the elaborate headdress, the contour. of the face, and the platted objects hanging down in front of and behind the chest, from the neck, are similar in both. The lowest zone is decorated with vases having handles at the sides, narrow necks, and flaring rims from which project flame-like tongues; on the outer surface of each is depicted an "Ahau" sign. The vases alternate with curious oljects which might represent bales of merchandise; the whole, indeed, closely resembles the tribute count of some Aztec city. 


\section{EXPIJANATION OF PLATE 24}

The cylindrical vase shown in plate 24 is 6 inches in diameter by 11 inches high. It is divided into three zones, the uppermost of which contains a single row of hieroglyphics, in fair preservation, between a broad red band above and two narrow black bands below. The middle zone, by far the broadest, contains two very spirited representations of the Long-nosed God, one on each side of the vase, done in red, llack. white, and dark yellow. The Long-nosed God, called by Schellhas in his "Representation of Deities of the Maya Manuscripts" God B, is usually identified with Cuculcan, the feathered serpent; the Aztec Quetzalcoatl. This god is usually represented with a long pendulous nose and one or two projecting tusks, and is almost in variably associated with the serpent. The head of the god is often held between the serpent's open jaws, or has added to it a serpentine body; again the god may be encircled by intertwining serpents, or may hold the reptile's body in his hand, like a wand. Though the serpentine attributes of the god are in this instance conspicuous by their absence, and the tapir attributes are emphasized, there can be little doubt that the painting is meant to represent God $B$; as the long pendulous nose and projecting tusks are highly characteristic of that god. The lowest and narrowest zone of this vase is covered with alternating red and black lines. 


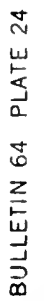

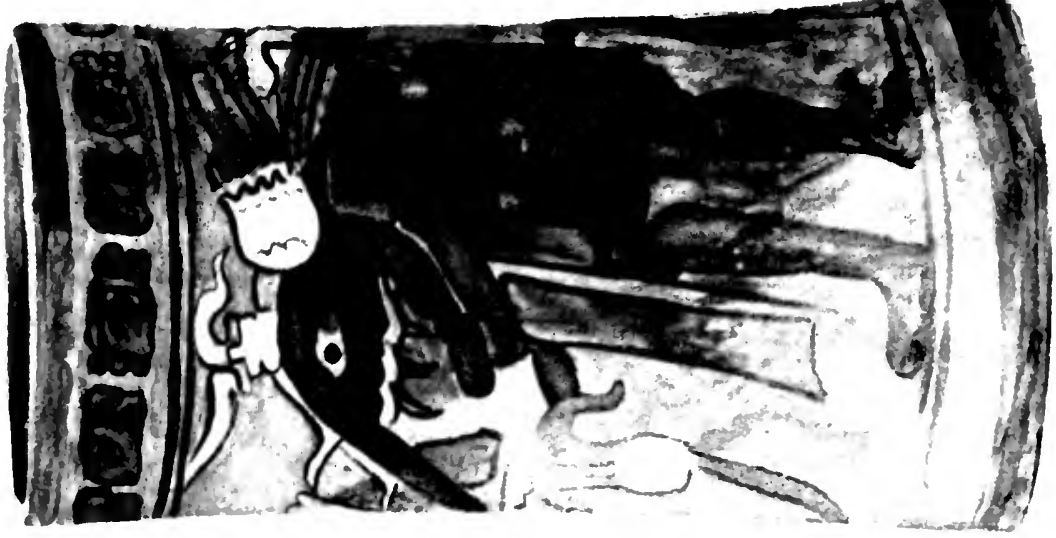

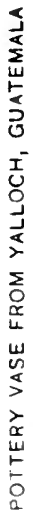

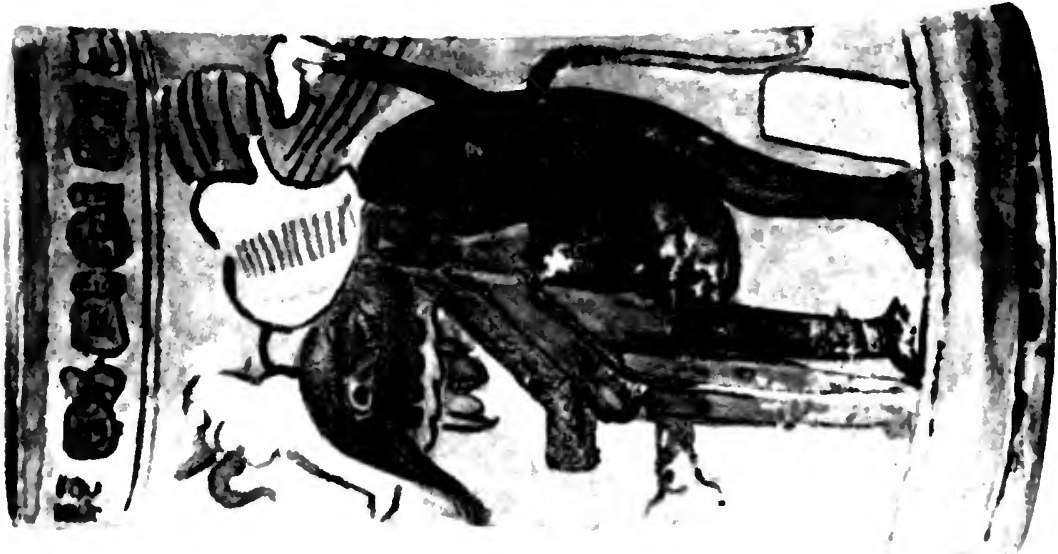





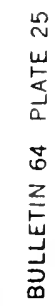
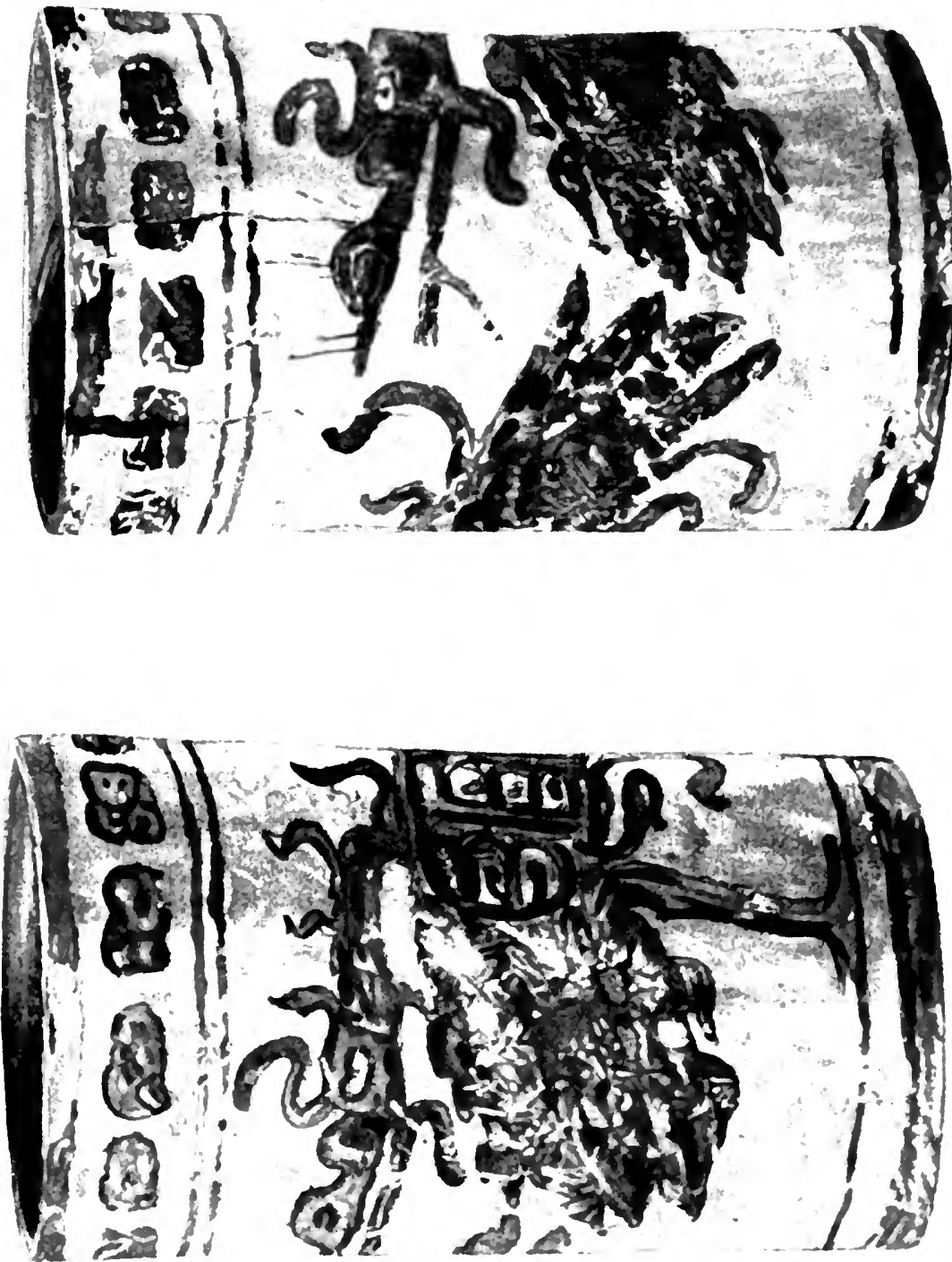

EXPLANATION OF PIATE 25

The cylindrical vase shown in plate 25 is $7 \frac{1}{2}$ inches in height by $4 \frac{1}{2}$ inches in diameter. The whole of the decoration upon it is in light and dark red on a light yellow background, and, like the two previously described vases, it is divided in to three decorative zones. The uppermost zone contains a single row of glyphs, almost indecipherable, apparently from constant use of the vase before it was buried. The middle zone contains two very remarkable mythological creatures, one on each side, whose feather-covered bodies, long legs, and large feet are suggestive of the ostrich. The necks are long and covered with flame-like projections, and both they and the hrads, with their huge elongated jaws, are evidently intended for those of feathered serpents. The lowest zone of the vase is narrow, and contains only a narrow and a broad recl stripe.

$70806^{\circ}-18-$ Bull. $64-10$ 


\section{EXPIANATION OF PLATES 26, 27, AND 28}

The pottery cylinder shown in plates 26,27 , and 28 is $10 \frac{1}{2}$ inches high by 4 inches in diameter and is withont a bottom. It is most exquisitely decorated in light and dark red and dark yellow on a light yellow background, and is also divided into three decorative zones. The uppermost zone contains only a single row of hieroglypls, very much defaced, among which may still be recognized several of the Maya day signs. The middle zone, by far the broadest, is covered by a most intricate design, containing human and mythological figures and hieroglyphs, with ornamental plumes, plats, and pendants; the whole, owing to the partial obliteration of the design, being extremely difficult to make out. On one side is seen a highly conventional representation of what is undoubtedly intended for the feathered serpent, with tail bent around to join the upper part of the head. The feathered serpent appears to permeate all Maya art in this section of the Maya area; whether painted on pottery or stucco, or incised on bone, pottery, or other material, one encounters him at every step. The serpent rests upon a row of glyphs, very much defaced, and below this is a mass of bows, knots, plumes, and glyphs. Farther along is a fierce-faced human figure, probably a warrior, with lofty and elaborate headdress, ornamented with many long feather plumes. Between the warrior and the serpent is a row of eight cartouches, superimposed one upon the other, each containing glyphs, a good deal defaced, among which the "Ahau" sign may still be clearly made out. The opening glyph in this panel may refer to the katun 8 Ahau. This katun can end in 8 Ahau only once in 260 years, or twice in the ninth cycle, namely, on 9.0.0.0.0.8 Ahau, $3 \mathrm{Ceh}$, and on 9.13.0.0.0.8 Ahau, $8 \mathrm{Uo}$; and it is reasonable to suppose that if this is a calendar record it refers to some date in the ninth cycle. Naranjo, the nearest ancient Maya city to Yalloch, was occupied for a period of approximately 12 katuns, or 240 years, ${ }^{1}$ between 9.7.10.0.0 and 9.19.10.0.0; if this glyph, therefore, refers to a katun ending in 8 Ahau in the ninth cycle, the date 9.13.0.0.0 is certainly indicated. 


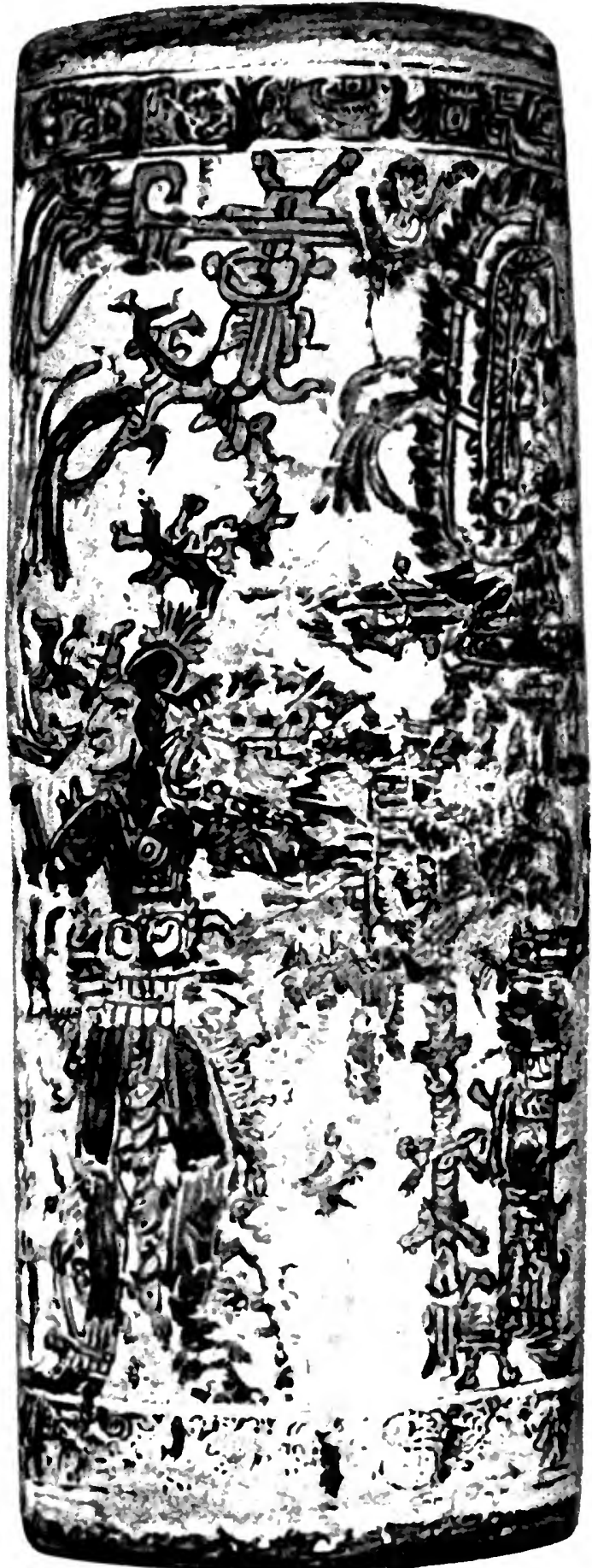





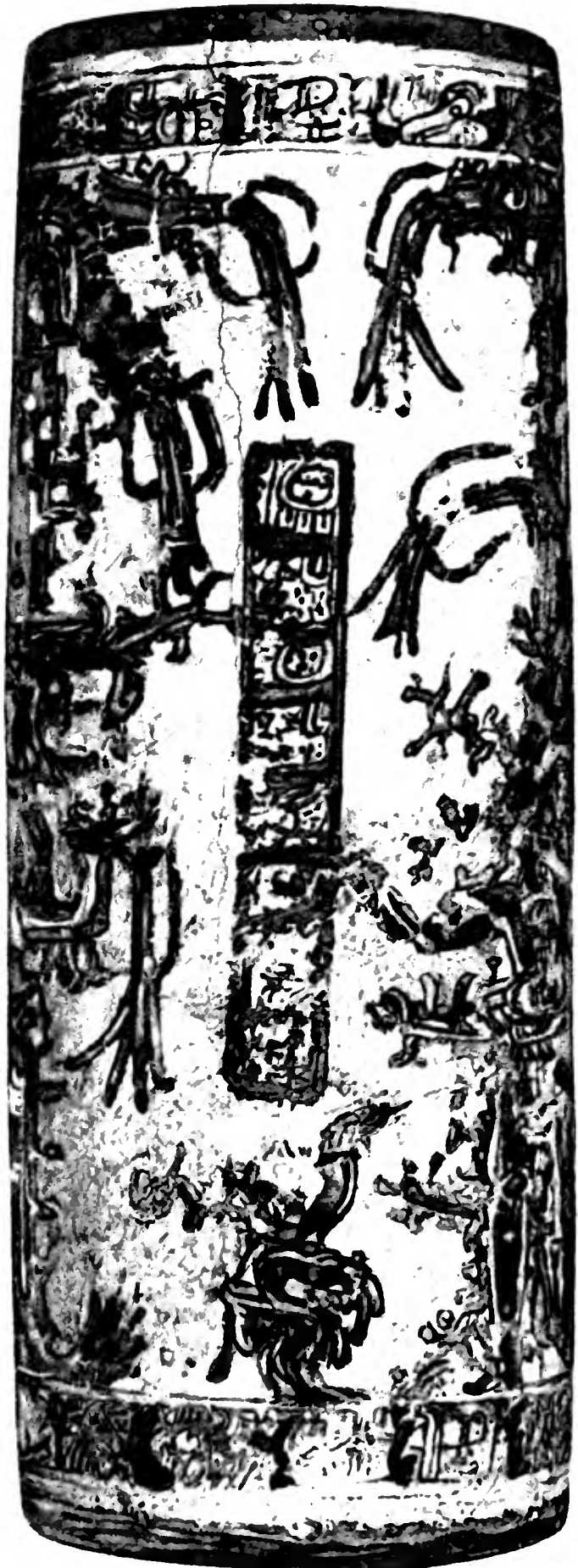





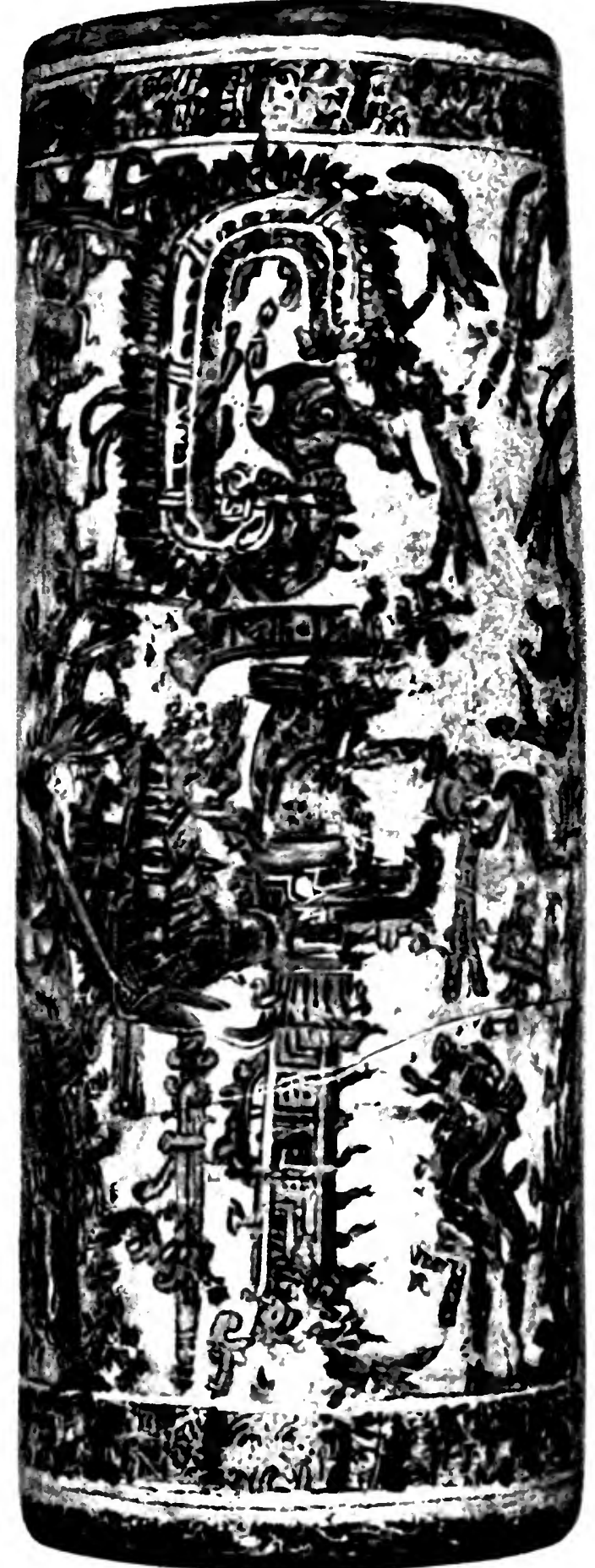





\section{AUTHORI'TIES CITED}

Brinton, Daviel G. The Maya chronicles. Brinton's Library lhoriginal Imeric an Literature, vol. 1. Phila. 1882.

Cinaknay, Désiné. Voyage au Yucatan et au pays des Lacandons. La Tour du Monde, vol. Xlvil, pp. 1-96; vol. Xuvin, pp. 33-45. I'aris, 1S84.

Cogolludo, Juan Lopez de. Historia de Yucatlan. Madrid, 1689.

Gaxx, Thomas. On exploration of two mounds in British Ilonduras. Proc. Soc. Ant. London, 2 d ser., vol. xv, pp. 430-434. Iondon, 1894-95.

On the contents of some ancient mounds in Central America. Ibid., $2 \mathrm{~d}$ ser., vol. $\mathrm{xvi}, \mathrm{pp}$. 30-317. London, 1896-97.

Mounds in northern IIonduras. Nincteenth Rept. Bur. Amır. Ethn., pt. 2, Jp. 155-692. Washington, 1900.

Joyce, Thomas A. Mexican archæology. New York, 1914.

IAANA, MIEGO DE. Relation des choses de Yucatan. Texte Espagnol et traduction Francaise. Published by Brasseurde Bourbourg. Paris, 1864.

Malen, Trobert. Researches in the central portion. of the Esumatsintla Valley. Pt. 2. Mem. Peabody M/us., vol. i, no. 2. Cambridge, 1903.

Explorations in the Department of Peten, (iuatemala. I/fm. I'cabody I/us., vol. w, no. 2. ('ambrillge, 1908 .

Maudsiay, A. P. Explorations in Guatemala. Pror. Royul Gicoy. Soc, vol. v, no. 4. pp. 155-204. Iondon, 1883.

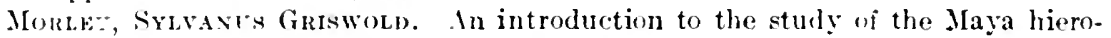
glyphs. Bull. 57, Bur. Amer. Ethn. Washington, 1915.

Reracios de la villa de Valladolirl. Actas Cong. Int. Amer., Madritl, 1881. vol. it Madrid, 1884.

Rezaciox de los pueblos de Popola y Sinsimato y Samiol. ('olecrion de dorumentos inerlitos, relutivos al descubrimiento, conquistu y colonizarion de las posesiones Espanolas en Americr y Oceanire. 2d ser., vol. xin. Madrid, 1900.

Sindex, H. J. A study of Maya art. Mem. Peabody M/us., vol. vi. ('ambridge, 1913.

Stefluexs, Johx I. Incidents of travel in Yuratan. Vols. 1-n. New York, 1st3. Tummas, ('yous. 1)ay symbols of the Maya year. Sixtecnth R'p p. Bur. Amer. Ethn., pp. 20.5-264. Washington, 1897.

Tozzkr, Alfren II. A preliminary study of the prehistoric ruins of Nakum, liunte-

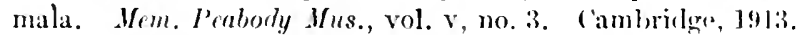

comparative study of the 'layas and hacandones. P'wh. Archeol. Inst. Amer. Xinw York, 1967 .

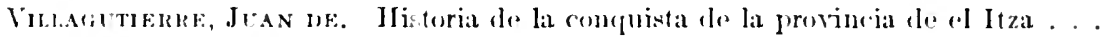
a las provincias de Yucatan. [Madriel], 1701. 

Page

AGRICULTURE, most important occupation of Indians.

ALCOHoL, effect on Indian temperament....

Asulets, worn by women.

ANIMALS-

Domestic, kept by ancient inhabitants.. kept for pets.

$\Lambda$ RTS OF TUE ANCIENTs, fine examples dis-

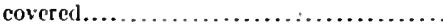

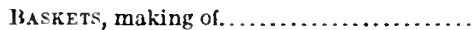

BLEEDI.NG, favorite remedy.

BoNEs, measurements of ................

Bristol MUSEUM, objects from collection of.

Britisil HoNduras, Northern, geograplical description of.

IBRITISH MUSEUM, objects from collection of.

CANDles, methorl of making..............

CANOES-

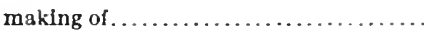

used for trading along rlvers.

CEREMONIES, the four principal ..............

Ceresony, Cila cluac, at ripening of corn, description.

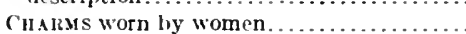

('illef-

power practically absolute.............

rarely dies natural death.

strongest subchief usually succeels......

CHILdBIRTI, methols of facilitating..........

CHILDREs, love for and disposition of........

chrowologr, three periods of Mayan cuvilization.

Cigarettes-

making of.

smoked by women

Cooklxs, natre methols of ...............

(")oklNi; [-TExsLs, description of...........

Conx-

liarvesting and storing ot............. preparation of ground and planting of... surplus solı or exclianged. ............

('OR. IIUSks, wrappers for cigaret tes........ corn plantation. See Milpa.

"culex RIDGes"-

description of.

sit es of ancient monnds. ............... sites of molern villages.

I)EATH SENTENCE, how exrcut'

I)IE: T-

deseriftion ol.

maize staple article of, among ancient inhabitants.

DISFASER -

blepling for.

"sietrouble, remuly for...

intestinal parasites.

nularia...

smillipox.

vinereal.

whoping eolagh, remedy for.

IIRE:4

anclent inlusbitunts..

ancient pruests......

ancient warriors.
1)RESS-Continued.

now princıpally English and American goods.........................

DRUNKENNESS-

curse of the Indians................. 34

not consldered a disgrace............. 3.1

Fire, methors of making................... 22

Fis -

methords of catching............... 25

varicties of ....................... 25

FisIING-

harpooning at might............... 25

methoils of ...................... 25

torch used in .................... 25

Foon-

animals used as, by ancient lnhabitants.

kind and methor of eating modified by contact with morc civilizel communi-

ties..............................

method of serving and eating...........

preparation and serving of..............

snakes used as.....................

turt les' eggs used as..................

Fow Ly, use of, in Cha chac ceremony.......

FURNITURE-

description of.......................

hammocks conspicuous articles of........

GAME-

pursuit of...........................

traps used in capturing............... 24

GAME BIRDS ANI ANIMALS-

list of............................

preparation and curing ol, for future use. 21

Gasies-

of the a neient inhabitants............. 56

plased by alints and chiliten......... $\quad 39$

IIA MIOCK:-

conspicuous articles of furniture....... 27

hiding places for "cooties" .......... 27

IIEADDRESSES-

ancient warriers and priests.......... 52

animals carved in woorl. . . . . . . . . . 52

IIENEQTEN FIBER

methol of eleaning................

uses of.......................... 31

LloMEs, not particular as to cleanluness of... 16

Jlookworus, prevalent, fur to eartheating

habits of chuldren.................... 37

IIOL'SE:S-

anclent, description of .............. is

luilt with assistance of neighbors....... 2it

methes of construction.............. 2ti

huntisi, torch insed 1 n................ 21

losicut, estimate of population . . . . . . . . 13

Imansuit, lirought about by cleagness of rum. .

Ixthase, equses of early douthe

IT7.4, eccupylng western IBritish Homheras. 13

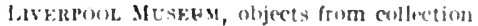

of.....

MACAPAL-

cirried by chudren, cabusing lum logs.

descrijtion of its nise.

haluts achultod ly constant carrang of 
Macapal-Continued.

Page

weiglited with stones as counterpoise in

traveling..........................

M.ichetr, used as tool and weapon.........

Malaria-

cluef scourge of Indians.

treated by sweating..................

Marriage-

agc of...

all degrees of racial mixture............

eeremony often delayed ................

Maya women to Negro men common....

not legal among Santa Cruz unless per-

formed by certain official.

obligation some what loose ...............

usually by Catholic priest ..............

MAssage, practiced by midwives............

I.A.A, progenitors of present inhabitants....

MEDictine, list of plants used as.............

MEN-

cruelty of, often in nature of reprisal..... dress of. .......................... example of cruelty of master to servant.. have no desire to accumulate wealth..... mental characteristics of................. occupation of.

skillful in finding routes and in following tracks.

stoical in bearing pilin

Metite-

superseded by hand mills.

Mil.PA-

..............

many fruits and vegetables grown in .... preparation of

Moccasins, making of.

Mosetitoes, carriers of malaria..........

Mounus-

a)undant on fertile soil

classification of . contents indicate physical appearance of ancient inhabitants................ manner of construction

Musecy of THE AMERICAN Jxdiax, objects from collection of .................. ODOR, peculiar.

OrLs, for cooking and lighting............. ORximexts, worn by ancient inhabitants...

"Pixe RidGes," description of..............

Pl.1xts, list of, used as medicine...........

PotTery-

ancient, description of................ ancient, ornamentation of.............. slight attempt at decoration............

POTTERY MAKING-

exclusively by older women........... no polish, glaze, or paint applied........ rendered unnecessary by iron pots and

earthenware.......................

Propertr, disposition of, at death.........

Prisiment

fine, flogging, and death only methods of. for witcheraft or sorcery................. imprisonment as, unknown............

\section{RELIGION-}

aneient inhabitants

Catholic priests not permitted for mony

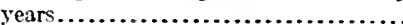

Christianity a thin veneer..............

four principal ceremonies................

human sacrifice by the ancient inhabi-

tants.

Indian conception of..............

native priests appointed.

RELIGIOUS ALTARS, draped and decorated..

RUM -

made locally.

women usually drink privately

SANDALS, worn by ancient inhabitants.....

Santa Cruz TRIBE-

emigration of.

estimate of

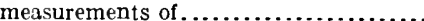

physical description of..................

policy of extermination of, by Mexican

Government........................

\section{SMALLPOX-}

terrible scourge.......................

treatment for, often disastrous...........

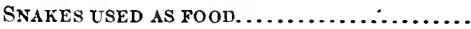

SPINNLNG-

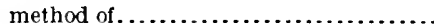

no longer practiced....................

universal among ancient women..........

SPIRIrs, belief in ........................

Superstition, "Santa Cruz" oracle.........

SURGERY, practice of.....................

TEETII, filed and filled with plugs...........

TOBACCO-

curing of . . . . . . . . . . . . . . . . . . . . .

vanilla leaves mixed with, to give flavor and fragrance.......................

TORCH USED IN FISHING ..................

ToRTILLAs, preparation and cooking of ......

TraPs Used in CaPturing GaMe............

TURKEY, use of, in Cha chac ceremony .......

VILLIGES-

description of..........................

foreigners not permitted to reside in....

frequent changes of sites...............

locat ions of, carefully concealed..........

WEAPONS-

defensive, of ancient inhabitants....... 53

offensive, of ancient inhabitants........ 52

WEAVING-

method of ............................... 29

no longer practiced................... 17

WOMEN-

dress of ............................

in gala costume present attractive ap-

pearance..........................

industrious workers. ................. jewelry and ornaments worn by .......... obscene and disgusting language used by . occupation of ........................ personal cleanliness of................. physically and mentally superior to men. social characteristics of . ...............

YUCATAN, geographical description of....... I UCATECAN TRIBEs, immigration into northern British Honduras............... 






EI 
